UC-32, 78, and 79

Reporting Date: July 1974

Issued: December 1974

\title{
KACHINA: an Eulerian Computer Program for Multifield Fluid Flows
}

by

Anthony A. Amsden

Francis . H. Harlow 
er bas .8T . Se.0u

ACe! vin! : sto Q pritroges?

AreI Isdmexal bojeci

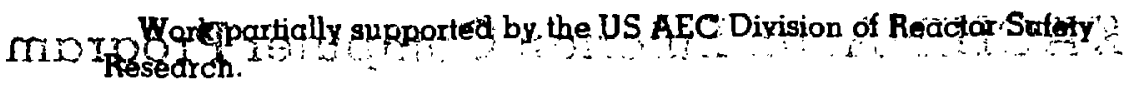

ewro:

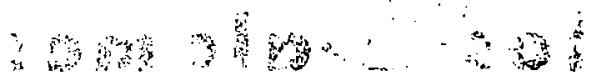

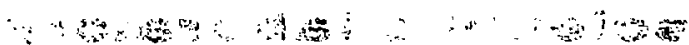

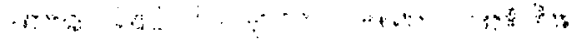

Printed in the United States of America. Available from National Technical Information Service

U.S. Department of Commerce

5285 Port Rayal Road

Price: Printed Copy $\$ 5.45$ Microfiche $\$ 2.25$

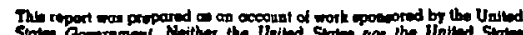

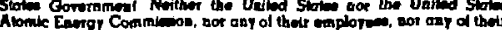

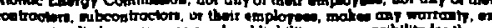

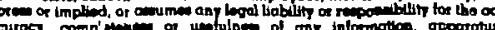

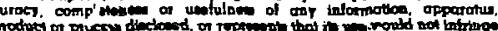

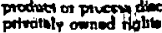


Abstract

I. Basic Descriftion of the Computing Kethod 1

A. Introduction 1

B. The Variables and the Computing Mesh 2

C. Phase 1-Exp1icit Calculations 4

D. Phase 2-Implicit Calculations 10

E. Boundary Conditions 15

F. Sudden Incompressibility 17

II. The KACHINA Computing Program 18

A. General Structure 18

B. The Indexing Notation 19

C. Storage of Cell Data 20

D. An Optional Three-Row Buffering Scheme 23

E. Marker Particles 25

F. The Input Data 27

G. Output - Plots, Prints, and Motion Hictures 31

H. Tape Dump and Restart 33

I. The Ccmon Block kSC 33

J. Microf $11 \mathrm{~m}$ Plots - Scaling and Subroutine CALLs 37

K. Miscellaneous System Subroutine CALLs 39

III. References 40

Appendix A. Flow Diagram for the KACHINA Program (June 19, 1974 Status) 4 !

Appendix B. FORTRAN IV Index Listing of the XACHINA Program (June 19, 1974 Status) 65

Appendix C. Modifications for LCM Storage of Cell Data 132

This report was prepared as an account of work
sponsored by the United States Government. Neither
the United States nor the United States Atomic Energy
Commission, nor any of their employees, nor any of
their contractors, subcontractors, or theis employees,
makes any warraniy, express or implied, or assumes any
legal Hability or responsibllity for the accuracy, com-
pleteness or usefulness of any information, apparatus,
product or process disciosed, or represents that its use
would not infinge privately owned rights.




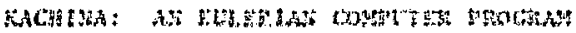

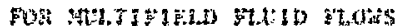

$5+5$

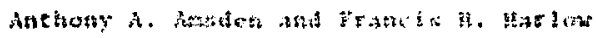

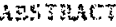

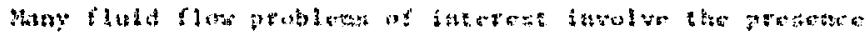

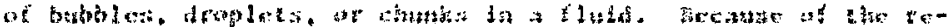

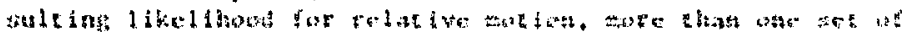

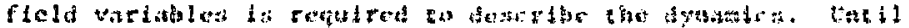

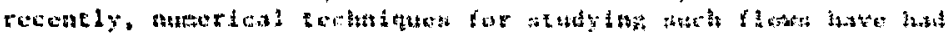

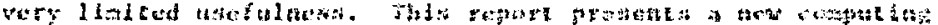

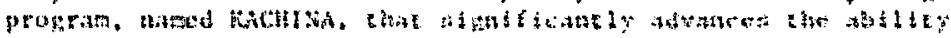

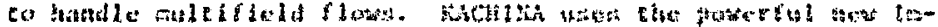

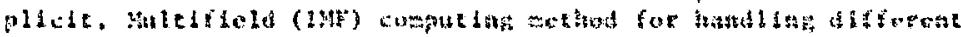

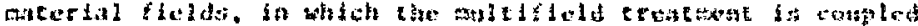

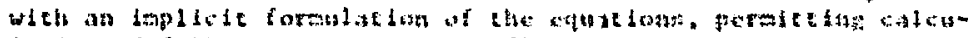

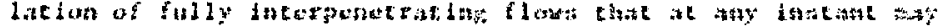

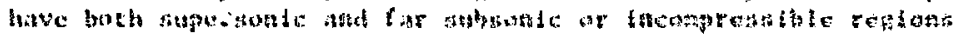

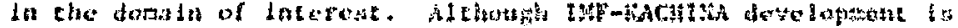

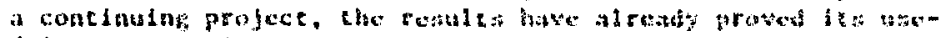

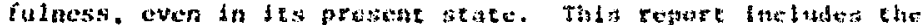
current BuCtsish

1. BASIC DESCRIPTION OF THE COMPLTISC METHOD

A. Introduction

The Implicit Cont Inuous-fluld Rulerian (tCE) method has become well known and whidely acespest since its Introduction, as te wibs the firist tectrnique co afford a means for numerheal solueton of multidimensional flows in which the stach number might range from zoro (the inconpressible linit) to greater than unity (the supersonic regise). The ICE concept has been recast in varfous formulitions; for example, in the YAQUI program. 2 ICE wis tomblned with the Arbitrary Ligrangian-EuIerian (MLE) eechnique, ${ }^{3}$ to provide the addicional capability of fully variabie zoning and rezoning. Other programi based on the ICE concept have included effects such as reactlve chemistry," magnetolyydrodynamics, ${ }^{5}$ and multiple fluids. ${ }^{6}$ This abflity to calculate a wide vartety of flows has contributed stgnificantly to an understanding of atmospheric explosion phenome-

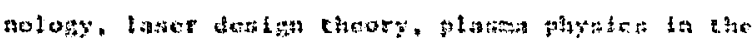

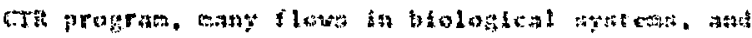

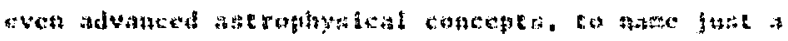
fเu.

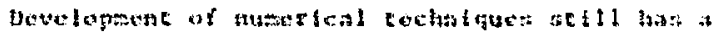

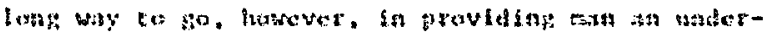

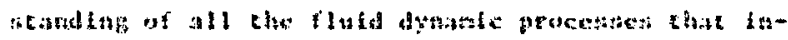

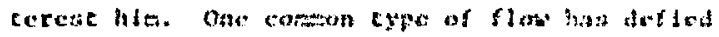

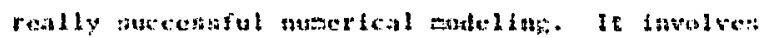
che presonec of bubles, aroplats, or chust: ta it

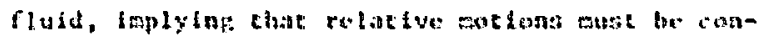
shored. and a comples set of rlold wariables it: fofuired to deseribe the dyateles weh aty accuracy. Examples of such flows are:

- Ordinary anow, rats, or hatl falliagr chrough the atmosphere.

- Cavitation or flaghing flow, in which bubbles of vapor are formed from the fludd fracli. (Visualize the formation of stean by boiltaf. 
or the propagation of a flame front through a confincd explosive such as encased gunpowder .)

Liquid or vapor rising through a bed of solid grains in a fluidized dust bed.

- Jet entrainment, in which inmisctble or mutually diffusing liquid droplets are carried along or mixed with another 1iquid.

Until recently, numerical techniques for examining such multifleld processes were extremely 1 imited. A powerful new computing cechnique, 7 known as the Implicit, Multifield (IMF) method and based, onse agatn, on ICE, is now avallable to help overcome these 1 imitations and thus significantly advance the art of modeling multifie?d flows. Thts report discusses a program named KACHINA, which embodies the IMF methodology. Our treatment is based upon an implicit formulation of the coupled set of differential equations for multidimensional, multifield flow. Because of the program's Eulerian aspects, it can follow completely interpenetrating material tnotions over long periods of time, and because of the implicit treatment of mass convection and the equation of state, the flows at any instant may have both supersonic and far subsonic regions in the domain of interest. Further, the implicit coupling of the fields allows forces to range from negligibly weak to strong enough to tie the fields together completely. The program also can pile up a particulate field into a close-packed region with a variable boundary position, and possibly reopen such a region later.

Development of IMF and KACHINA is an expanding and continuing project. In its present basic state, KACHINA is still fairly IImited and does not take into account a number of physical processes that will be required for future applications. It has, however, proved its usefulness everi at this point, and has pernitted meaningful calculations of a variety of one- and two-dimensional two-fleld flow situations that could not have been made using previous techniques. This report includes the current version of the KACHINA flow diagram and program listing. The derivation of the technique is fully described In Ref. 7, which also includes examples of a variety of test calculations illustrating sone of KACHINA's capabilities. We therefore omit such aspects here, and concentrate on the solution pro- cedure and the equations as they appear in KACHINA. B. The Variables and the Computing Mesh

For siaplicity, we presently limit our consideration to two primary material fields, although the IMF principle is not restricted to these two, but will be developed further into a three-field model, including full treatment of phase transitions among the fields. We label these two fields "vapor" and "droplets." The vapor field may be considered to be a gas In bubble form or with oispersed droolets in $i t$, and the droplet field to be a fluid or an aggregate of solid particles. The components of eacis fleld have constituents and properties that can vary in space and time, but pressure is assumed to be in local equilibrium between the two fields. The pressure is related directly to the equation of state of the vapor when the droplet fleld is disperse, or to the maintenance of incompressibility when the droplet field is close-packed.

At present, the coupled fields are represented on a iwo-dimensional axisymmetric grid of fixed Eulerian crels through which the fluid moves. Cells have uniform dimensions $\delta r$ and $\delta z$, measured in the radial ( $r$ ) and axial $(z)$ directlons, respectively, and they are labeled by indices located at their centers, with 1 counted in the $r$ direction and $j$ in the $z$ direction. The mesh of cells is $\overline{\mathrm{I}}$ cells wide by $\bar{J}$ cells high, as shown in Fig. 1 .

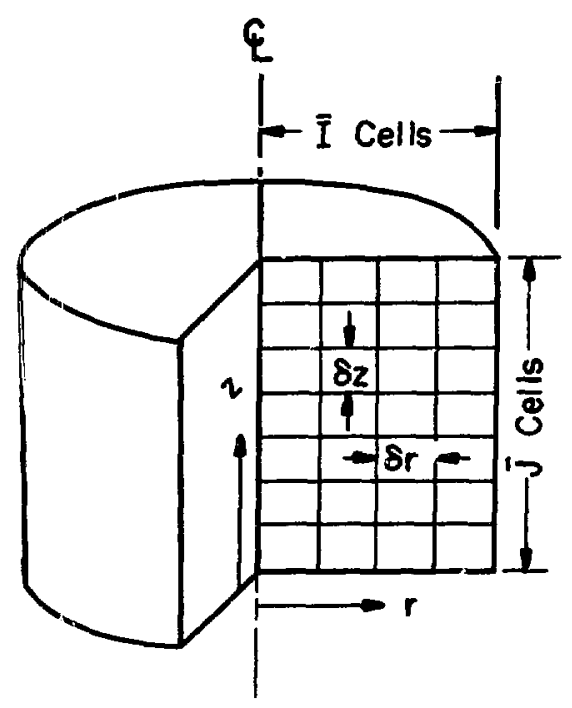

Fig. 1. The RACHINA axisymmetric two-dimensional computing mesh. 
Variables may be defined either at cell centers or at cell edges, in which case they are labeled by half-integer indices in the fintte-difference notation. The location of the principal KACHINA variables about a cell $(1, j)$ is illustrated in Fig. 2, where $u$ and $v$ are velocity components in the radjal and axial directions, respectively, $\rho$ is the density, and $I$ is the specific internal energy. Each of these four variables has both vapor and droplet components, denoted by the subscripts " $v$ " and "d," respectively. The pressure, $p$, has only a single value in the cell because of the local equillbrium between the two fields.

The treatment of such a mixture of droplets and vapor, and the procedure for applying the equation of state to the vapor, requires a knowledge of the proportions of vapor and droplets within any given cell volume. For this purpose, we use the void fraction, $\theta$, defined as the volume per unit total volume occupied by vapor. Consequently, $(1-\theta)$ is the volume per unit total volume occupied by droplets.

In addition, we allow two components within each fleld, designating them by subscripts 1 and 2 . One must be able to describe the varying relative proportions of the two components in a way that ensures the separate conservation of each. For either fleld,

$\theta_{1}=\theta_{2}$,

and $\rho^{\prime} \equiv \rho_{1}^{\prime}+\rho_{2}^{\prime}$.
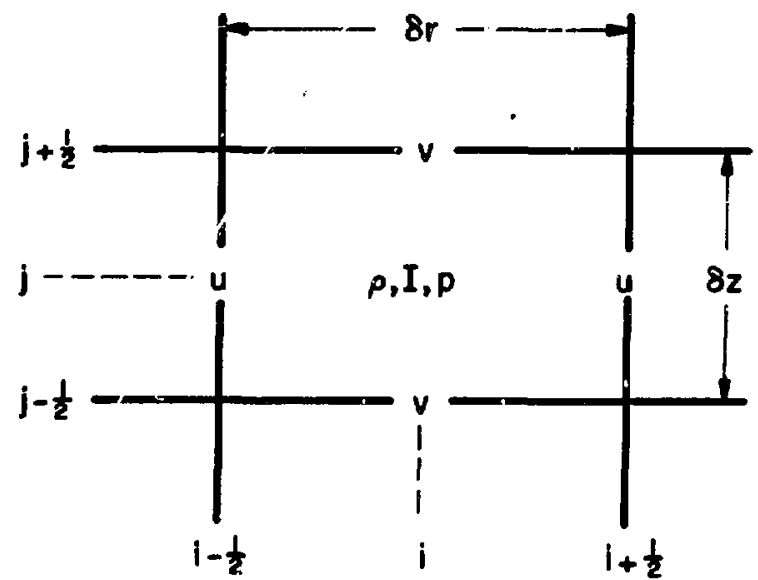

Fig. 2. Location of variables and indices about a KACHINA $c \in 11$. in which the prime signifies the mass per unit total volume. For the droplets, we use conservative explicit equations to transport the two densities $p_{d}$ and $\rho_{\mathrm{d} 1}^{\prime}$, and get the value of $\rho_{\mathrm{d} 2}^{\prime}$ simply by subtraction when necessary. Then, with the corresponding normal mater $\lrcorner$ al densities $\rho_{1}$ and $\rho_{2}$ defined, microscopic incompresstbiltty allows derivation of an expression for the region's effective $\theta$.

For the vapor, an equation for $\rho_{v}^{\prime}$, the sum of the two vapor densities, is required for the implicit coupling with the momentum equations. After this advanced-time density and the corresponding advancedtime velucities have been determined, $\rho_{v 1}^{\prime}$ can be obtained by means of a second implicit solution. As in the case of the droplets, the value of $\rho_{v 2}^{\prime}$ is avai: ble by subtraction when needed.

Thus, it is seen that the ccuplete arrays of four densities must be stored and maintained, two for each fleld, and that we have chosen these to be $\rho_{\mathrm{d} l}^{\prime}$ and $\rho_{\mathrm{d}}^{\prime}$ for the droplets, and $\rho_{\mathrm{v} 1}^{\prime}$ and $p_{\mathrm{v}}^{\prime}$ for the vapor.

The Input data used to create the droplet and vapor fields specify the intial values of $\rho_{\mathrm{d} 1}^{\prime}, \rho_{\mathrm{d} 2}^{\prime}$, $\rho_{v 1}, \rho_{v 2}, I_{v}$, and $I_{d}$ for all cells of the mesh, where $P_{v 1}$ and $P_{v 2}$ are the actual microscopic (partiaj) densities of the two vapor components. Using this Information, one may place $I_{v}, I_{d}$, and $p_{d l}^{d}$ directly in cell storage, but generation of the Initlal fields of $\rho_{d}^{\prime}, \rho_{v l}^{\prime}$, and $\rho_{v}^{\prime}$, along with $\theta$, requires some preliminary calculation.

- The field of $\rho_{d}^{\prime}$ is formed simply from the sum of $\rho_{d 1}^{\prime}$ and $\rho_{d 2}^{\prime}$.

with the normal material densities $\rho_{1}$ and $\rho_{2}$ of the droplet field components also spectfied in the input data, the initial void fraction is obtained from the relationship

$\theta=1-\frac{\rho_{d 1}^{\prime}}{\rho_{1}}-\frac{\rho_{d 2}^{\prime}}{\rho_{2}}$.

The values of $\rho_{v 1}$ and $\rho_{v 2}$ are then combined with $\theta$ to obtain the fields of $\rho_{v 1}^{\prime}$ and $\rho_{v}^{\prime}$ : $\rho_{\mathbf{v} 1}^{\prime}=\theta \rho_{\mathbf{v} 1}$, $\rho_{v}^{\prime}=\theta\left(\rho_{v 1}+\rho_{v 2}\right)$. 
Care must be taken to ensure that the input data are not specified incorrectly so that $\theta<0$ results.

In the present code, the dynamics are assumed to arise from pressure gradients from internal heat sources, or as the result of externally applied boundary conditions and/or gravitational effects. Therefore, all four velocity components, $u_{v}, u_{d}$, $v_{v}$, and $v_{d}$ are initially set to zero throughout the interior of the mesh.

Because the vapor and droplet fields are to'snd by forces that wan create conditions ranging from a cumplete tying together to the allowance of freely independent motion, a drag function, $K$, is used to relate the momentum exchange between the fields.

other sell quantities will be introduced in the discussion of the full calculation cycle, but those described so far may be considered the principal KACHINA variables.

Solution of the dynamics evolves through a sequence of cycles, or time steps, each of duration ot. For each time step, the full coupled set of equations is solved to get the new values of all the field variables at a time $\delta t$ later. This solution uses the results of the previous cycle or the set of initial conditions, and it is stored so as to allow the processing to be repeated in the next cycle.

Each cycle in KaCHINA is composed of two disrinct phases. The explicit calculations are performed in Phase 1 , and all implicit aspects are then handled in Phase 2.

c. Phase 1-Explicit Calculactons

In Phase 1 , we have collected all the explicit calculations for the cycle. There are two major parts in this phase, the first concerned with calculating new values of scalar virfables defined at cell centers, and the second with calculating naw values of the cell-edge momenta. Performance of the first part is the responsibility of a sweep over all the interior cells of the mesh, which solves the equations for ${ }^{n+1}\left(\rho_{d}^{j}\right)_{1}^{j},{ }^{n+1}\left(\rho_{d l}^{\prime}\right)_{i}^{j},{ }^{n+1} \theta_{i}^{j}, A_{1}^{j}, \tilde{p}_{i}^{j}$, $K_{i}^{j},{ }^{n+1} I_{v}$, and ${ }^{n+1} I_{d}$. In our notation, the superscript " $n$ " indicates the old value of a quantlty at tile beginning of the cycle, and " $n+1$ " Indicates the new value at the end of the cycle. Immediately at the beginning of a cycle, we can calculate the final values in that cycle of all these quantities, except the pressure $\widetilde{\mathrm{p}}$, as they are not subject to further modification in Phase 2. The subsidiary quanticy
$A_{i}^{j}$ has the dimensions of an internal energy $I_{v} ;$ it appears in Phase 1 to supply the energy tern for the equation-of-state pressure for the vapor, as will be described below. It is subscripted and saved for later use as a necessary coefficient in Phase 2 . The droplet density equations are

$$
\begin{aligned}
n+1\left(\rho_{d}^{\prime}\right)_{i}^{j} & =n\left(\rho_{d}^{\prime}\right)_{i}^{j} \\
& \left.+\frac{\delta t}{r_{i} \delta r} \mid n\left\langle u_{d} r \rho_{d}^{\prime}\right\rangle_{i-\frac{1}{2}}^{j}-n\left\langle u_{i} r \rho_{d}^{\prime}\right\rangle_{i+\frac{1}{2}}^{j}\right] \\
& \left.+\frac{\delta t}{\delta_{z}} \mid{ }^{n}\left\langle v_{d} \rho_{d}^{\prime}\right\rangle_{i}^{j-\frac{1}{2}}-n\left\langle v_{d} \rho_{d}^{\prime}\right\rangle_{i}^{j+\frac{1}{2}}\right],
\end{aligned}
$$

and

$$
\begin{aligned}
{ }^{n+1}\left(\rho_{d l}^{\prime}\right)_{i}^{j} & ={ }^{n}\left(\rho_{d l}^{\prime}\right)_{i}^{j} \\
& \left.+\frac{\delta t}{r_{i} \delta r}{ }^{n}\left\langle u_{d} r \rho_{d l}^{\prime}\right\rangle_{i-l_{2}}^{j}-n\left\langle u_{d} r \rho_{d l}^{\prime}\right\rangle_{i+l_{2}}^{j}\right] \\
& \left.+\frac{\delta t}{\delta z} \mid{ }^{n}\left\langle v_{d} \rho_{d l}^{\prime}\right\rangle_{i}^{j-\frac{1}{2}}-{ }^{n}\left\langle v_{d} \rho_{d l}^{\prime}\right\rangle_{i}^{j+l_{2}}\right],
\end{aligned}
$$

where the angular brackets \langle\rangle indicate a partial donor-cell treatment of the convective flux of the enclused quantity. The use of the donor-cell differencing facilitates automatic mitigation of truncation-error effects ${ }^{8}$ without requiring an explicit artificial difrusion. According to our formulation, the convective flux of solu cell-centered quantity, $Q_{i}^{j}$, at cell buundary $\left(i+\frac{1}{2}, j\right)$ would be given by

$$
\langle u r Q\rangle_{i+l_{2}}^{j}=(u r)_{i+\frac{1}{2}}^{j}\left[\left(l_{\xi}+\xi\right) Q_{i}^{j}+\left(l_{2}-\xi\right) Q_{i+1}^{j}\right] \text {. }
$$

where

$\xi=\beta_{o}\left(\frac{u_{i+{ }^{j}}^{j} \delta t}{\delta r}\right)+\alpha_{0} \operatorname{sign}\left(u_{i+!_{2}}^{j}\right)$

and $\alpha_{0}$ and $\beta_{0}$ are input coefficients. For $\alpha_{0}=0$ and $\beta_{0}=\frac{1}{2}$, 5ill give an automatically interpolated donor-cell form. More commonly, however, we use 
$\beta_{0}=0$ and $0<\alpha_{0} \leqslant \frac{1}{2}$. With $\beta_{0}=0$, use of $\alpha_{0}=0$ would give pure space-centered differencing, which is numerically unstable in the absence of a mitigating diffusive process, whereas use of $x_{0}=\frac{1}{2}$ would give pure donor-cell differencing, which offers the greatest smoothing. The formulation of $\xi$ assumes that $1 u_{\max } \mid \partial t / \delta r<s_{2}$ everywhere, ordinarily a reasonable upper limit on $\delta$ for accuracy.

The atove transport equations for ${ }^{n+1}\left(r_{d}^{j}\right)_{i}^{j}$ and ${ }^{n+1}\left(\rho_{d 1}^{\prime}\right)_{i}^{j}$ allow us to rigorously conserve the masses of the two components separately, and with their values known, ${ }^{n+1} a_{i}^{j}$ is calculated from

$n+1_{\theta j} j=1-\frac{{ }_{i}^{n+1}\left(\rho_{d I}^{\prime}\right)_{i}^{j}}{\rho_{1}}-\frac{\left[n+1\left(\rho_{d}^{\prime}\right)_{i}^{j}-{ }^{n+1}\left(\rho_{d 1}^{\prime}\right)_{i}^{j}\right]}{\rho_{2}}$.

With ${ }^{n+l_{1} j}{ }_{i}^{j}$ now available, we can determine the energy term $A_{i}^{j}$. As an example, assume that we are using the polytropic gas equation of state, as we, in fact, do in this version of RACHINA. In this case, the pressure ordinarily would be given by

$p=\left(\gamma_{v}-1\right) \rho_{v} I_{v}$,

In which $\gamma_{v}$ is the ratio of specific heats in the vapor. This basic form, lowever, is insensitive to variations in the proporticns of components within the vapor, and it is unsatisfactory for direct use. To overcome this deficiency, we first define $A_{i}^{j}$, a necessary coefficient for Phase 2 iteration purposes, as

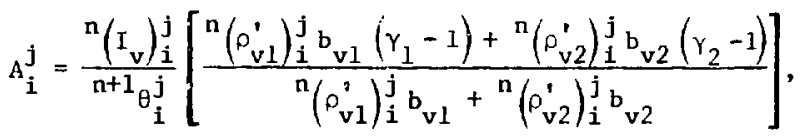

in which $Y^{\prime}$ 's and the specific heats, $b_{v}$ 's, are specified separately for each of the two components, and are provided in the input data. With $A_{i}^{j}$ determined, the KACHINA equation-of-state pressure is then calculated directly as

$p_{E O S}=A_{1}^{j} n\left(\rho_{v}^{\prime}\right)_{i}^{j}$
The initializing pressure, $\widetilde{p}$, actually stored in Phase 1 for a giver cell after the first cycle is some mixture of $p_{E O S}$ and the pressure ${ }^{n}$ p left over from the Phase 2 pressure iteration of the previous cycle. This treatment is required to allow the code to account for large variations in the fl.ow Mach number from place to place or as a tunction of time. We use a function $f$ of the local flow Mach n'mber $M$ to determine the exact proportions of this mixture, where

$\tilde{\mathrm{p}}=f^{\mathrm{n}} \mathrm{p}+(1-f) \mathrm{p}_{\mathrm{EOS}}$,

in which the desired limits are $f=1$ when $M+0$ and $f=0$ when $M+\infty$. We have found that relating $f$ to the square of the local Mach number,

$f=\frac{I}{1+10\left(\frac{M}{M_{0}}\right)^{2}}$,

gives satisfactory results, with $M_{0}=0.5$ and the coefficient 10 chosen to allow the equation of state to exert a strong enough influence. The Mach number is calculated using the standard $M=u / c$ form appropriate for a polytropic gas. ${ }^{9}$ Choosing a squared Mach number function ruakes $(l-f)$ vary inversely in proportion to the vapor internal energy as that quantity becomes large, consistent with the dependence of $p_{E O S}$ on that same variable. The choice also allows us to avoid taking a square root in the calculation of the sound speed, c. For calculations in which the sound speed becomes very large, the exponent should be greater than 2.0, in order that the equation-of-state effects disappear in that limit. Thus we have

$\left(\frac{M}{M}\right)^{2}=\frac{U^{2}}{c^{2} M_{0}^{2}}$

where the square of an appropriate average velocity for the cell $(i, j)$ is calculated as

$u^{2}=\frac{1}{4}\left\{\left[n\left(u_{v}\right)_{i+\frac{i}{2}}^{j}\right]^{2}+\left[n\left(u_{v}\right)_{i-\frac{1}{2}}^{j}\right]^{2}\right.$ 


$$
\left.+\left[n\left(v_{v}\right)_{i}^{j+\frac{1}{2}}\right]^{2}+\left[n\left(v_{v}\right)_{i}^{j-\frac{1}{2}}\right]^{2}\right\}
$$

$$
\left.+\left[n\left(v_{v}\right)_{i}^{j \cdot \mu_{2}}-n\left(v_{d}\right)_{i}^{j+l_{2}}+n^{n}\left(v_{v}\right)_{i}^{j-\frac{1}{2}}-{ }^{n}\left(v_{d}\right)_{i}^{j-l_{2}}\right]^{2}\right\}^{\frac{1}{2}}
$$

and the square of a suffictently accurate approxima-

tion to the sound speed can be shown to be

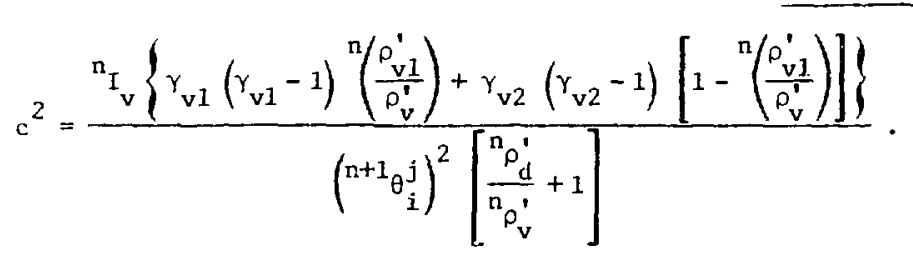

To allow greater generality, it is desirable to replace $U^{2}$ by $\left(U^{2}+p / \rho\right)$, in which $p / \rho$ is given by ${ }_{\mathrm{p} / \rho_{\mathrm{v}}}={ }_{\mathrm{p} \theta / \rho_{\mathrm{v}}}$. A flow starting from rest and driven by its own internal pressure will have an initial $p / \rho$ comparable to $c^{2}$, and later will develop $\mathrm{U}^{2}$ comparable to $\mathrm{c}^{2}$, thus tending to make $\mathrm{M}^{2}$ always comparable to unity. This formulation also automatically handles far subsonic flows, as in such cases, $p / \rho$ values and $U^{2}$ values will be much smaller than $c^{2}$, resulting in a small $\mathrm{M}^{2}$ and $\mathrm{f}$ of order unity.

The initializing vapor density, $\widetilde{\rho}_{v}^{\prime}$, for the cell is also stored at this time. It is based similarly on $f$,

$\widetilde{\rho}_{v}^{\prime}=f \theta \rho_{\text {vo }}+(1-f) \frac{\widetilde{p}}{A}$,

where $\rho_{\text {vo }}$ may be a specified constant for completely incompressible flow, or may be allowed to vary in case of buoyancy effects.

The next consideration is the drag function, $K_{i}^{j}$, which we calculate as

$k_{i}^{j}=\frac{3^{n}\left(\rho_{v}^{\prime}\right)_{i}^{j}\left(1-{ }^{n+1} \theta_{i}^{j}\right)}{2\left({ }^{n+1} \theta_{i}^{j}\right)^{2} r_{p}^{2}}\left[3 v_{v}+\left(\frac{{ }^{c} p_{R}}{4}\right)\left|\vec{u}_{v}-\vec{u}_{d}\right|\right]$,

$v_{v}$ is the coefficient of kinematic viscosity for the vapor, $r_{p}$ is the mean linear dimension of a droplet, and $c_{D R}$ is a drag coefficient. In the present version of KACHINA, these three quantities are simply read-in constants. In a future version, $r_{p}$ will be vastly generalized to include droplet growth or decrease in size, by such processes as evaporation, condensation, rupture, and coalescence. This generalization will be accomplished by means of a transport equation for $r_{p}$. At first, the generalization will involve the cell quantity $r_{1}^{j}$, and perhaps, later, an $r_{p}$ distribution that can vary with position and time. Our present constant value for $r_{p}$ is a useful first approximation, however, and it allows us to derive information about dependence of the results on the choice of droplet scale.

In theory, the $\theta_{1}^{j}$ 's appearing in the $k_{1}^{j}$ equation could be either ${ }^{n} \theta^{\prime} s$ or ${ }^{n+1} \theta^{\prime} s$, but our specific choice of ${ }^{n+1} \theta$ is based on computational requirements for suddenly incompressible flow. This point will be clarified in Sec. I.F.

The final quantitles calculated in the first sweep in Phase 1 are tha spectfic internal energies ${ }^{n+1} I_{v}$ and ${ }^{n+1} I_{d}$.

$$
{ }^{n+1}\left(I_{v}\right)_{i}^{j}={ }^{n}\left(I_{v}\right)_{i}^{j}
$$

where

$\left|\vec{u}_{v}-\vec{u}_{d}\right| \equiv \frac{1}{2}\left\{\left[n\left(u_{v}\right)_{i+\frac{1}{2}}^{j}-{ }^{n}\left(u_{d}\right)_{i+\frac{1}{2}}^{j}+{ }^{n}\left(u_{v}\right)_{1-\frac{1}{2}}^{j}-{ }^{n}\left(u_{d}\right)_{i-\frac{l}{2}}^{j}\right]^{2}\right.$

$$
\begin{aligned}
& +\delta t\left\{\frac{1}{r_{i} \delta r}\left[\left\langle u_{v} I_{v} r\right\rangle_{i-\frac{1}{2}}^{j}-\left\langle u_{v} I v\right\rangle_{i+I_{2}}^{j}\right]\right. \\
& \left.+\frac{1}{\delta z}\left[\left\langle v_{v} I v\right\rangle_{i}^{j-\frac{1}{2}}-\left\langle v_{v} I\right\rangle_{i}^{j+\frac{1}{2}}\right]\right\}
\end{aligned}
$$




$$
\begin{aligned}
& +\frac{\delta t}{\mathrm{n}_{\left(\rho_{v}^{\prime}\right)_{i}^{j}}}\left\{\rho_{i}^{j}\left[\left(\mathrm{~T}_{d}\right)_{i}^{j}-\left(\mathrm{T}_{v}\right)_{i}^{j}\right]\right. \\
& +k_{i}^{j}\left[\left(u_{d i}^{j}-u_{v i}^{j}{ }^{2}+\left(v_{d i}^{j}-v_{v i}^{j}\right)^{2}\right]\right. \\
& +\left.\frac{k_{v}}{r_{i} \delta \mathbf{r}^{2}}\right|_{i+\frac{1}{z}} ^{r_{i+1 / 2}}\left(T_{v i+1}^{j}-T_{v i}^{j}\right) \\
& \left.-\theta_{i-1 / 2}^{j} r_{i-1 / 2}\left(r_{v i}^{j}-\tau_{v j-1}^{j}\right)\right] \\
& +\frac{k_{v}}{\delta z^{2}}\left[\rho_{i}^{j+\frac{1}{2}}\left(T_{v i}^{j+1}-T_{v i}^{j}\right)\right. \\
& \left.\left.-\beta_{i}^{j-1 / i}\left(T_{v i}^{j}-T_{v i}^{j-1}\right)\right]\right\} \\
& -\frac{\tilde{\mathrm{p}}_{i}^{j} \delta t}{n_{\left(\rho_{v}^{j}\right)_{i}^{j}}^{j}}\left(\frac { 1 } { r _ { i } ^ { j } \mathbf { r } } \left\{r_{i+\frac{1}{2}}\left[\theta u_{v}+(L-\theta) u_{d}\right]_{i+\frac{1}{2}}^{j}\right.\right. \\
& \left.-r_{i-\frac{1}{2}}\left[\theta u_{v}+(1-\theta) u_{d}\right]_{i-\frac{1}{2}}^{j}\right\} \\
& +\frac{1}{\delta z}\left\{\left[\theta v_{v}+(1-\theta) v_{d}\right]\right]_{i}^{j+\frac{1}{z}} \\
& -\left[\theta v_{v}+(1-\theta) v_{d}\left|j-\frac{1}{2}\right|\right) \\
& +{ }^{n}\left(I_{v}\right)_{i}^{j} \delta_{t}\left\{\frac{1}{r_{i}^{i} \cdot r}\left[u_{v i+t_{i}}^{j} r_{i+\frac{1}{2}}-u_{v i-\frac{1}{2}}^{j} r_{i-\frac{1}{2}}\right]\right. \\
& \left.+\frac{1}{\delta z}\left\{v v^{j+i_{i}}-v_{v i}^{j-\frac{1}{2}}\right]\right\} \text {, }
\end{aligned}
$$

and

$$
\begin{aligned}
& { }^{n+1}\left(I_{d}\right)_{i}^{j}={ }^{n}\left(I_{d}\right)_{i}^{j} \\
& +\delta_{t}\left\{\frac{1}{r_{i} \delta r}\left[\left\langle u_{d} I_{d} r\right\rangle_{i-\frac{1}{2}}^{j}-\left\langle u_{d} I_{d} r\right\rangle_{1: Y_{1} / j}^{j}\right]\right. \\
& \left.+\frac{1}{\delta z}\left[\left\langle v_{d^{I}{ }}\right\rangle_{i}^{j-\frac{1}{2}}-\left\langle v_{d^{I}}\right\rangle_{i}^{j+\frac{d}{2}}\right]\right\}
\end{aligned}
$$

$$
\begin{aligned}
& +\frac{\delta t}{n\left(\rho_{d}^{j}\right)_{i}^{j}}\left\{R_{i}^{j}\left[\left(T_{v}\right)_{i}^{j}-\left(T_{d}\right)_{i}^{j}\right]+E_{i}^{j}\right. \\
& +\frac{k_{d}}{r_{i} \delta r^{2}}\left[\left(1-\theta_{i+\frac{1}{2}}^{j}\right) r_{i+\frac{1}{2}}\left(T_{d i+1}^{j}-T_{d i}^{j}\right)\right. \\
& \left.-\left(1-\theta_{i-\frac{1}{2}}^{j}\right)=_{i-\frac{1}{\zeta}}\left(T_{d i}^{j}-T_{d i-1}^{j}\right)\right] \\
& +\frac{k d}{\delta z^{2}}\left[\left(1-\theta_{i}^{j+\frac{1}{2}}\right)\left(T_{d i}^{j+1}-T_{d i}^{j}\right)\right. \\
& \left.-\left(1-e_{i}^{j-\frac{1}{2}}\right)\left(T_{d i}^{j}-T_{d i}^{j-1}\right)\right\}_{(}^{\prime} \\
& +{ }^{n}\left(I_{d}\right)_{i}^{j} \dot{D} t \frac{1}{r_{i}{ }^{r} r}\left[u_{d i+\frac{1}{2}}^{j} r_{j+\frac{1}{2}}-u_{d i-\frac{1}{2}}^{j} r_{i-\frac{1}{2}}\right] \\
& \left.+\frac{1}{\delta z}\left[v_{d i}^{j+\frac{1}{2}}-v_{d i}^{j-\frac{1}{2}}\right]\right\} .
\end{aligned}
$$

Time level $n$ is assume $f$ for all quantities in the right-hand sides of both of the above equations, except for $k_{i}^{j}$ and $\tilde{p}_{i}^{j}$, which are coefficients for the drag and work terms, respective il, in ${ }^{n+1}\left(I_{v}\right)_{i}^{j}$.

These two quantities are those just obtained, as cescribed above. Several new quantities appear in ${ }^{n+1}\left(I_{v}\right)_{i}^{j}$ and ${ }^{n+1}\left(I_{d}\right)_{1}^{j}$, and they require discussion.

$R_{i}^{j}$ is an exchange function that controls the heat transferred between the two fields per unit volume per unfit time, as a result of surface condiction. In general, $R_{i}^{j}$ will be a cell variable, although now it is a constant and no array is stored. It is a coefficient that multiplies the local termperature difference, in which the temperature $T$ is now given simply by the $I=b T$ relationship, and is calculated as

$$
n(T)_{i}^{j}=\frac{n\left(I_{v} \rho_{v}^{\prime}\right)_{i}^{j}}{n\left(\rho_{v 1}^{\prime}\right)_{i}^{j} b_{v 1}+{ }^{n}\left(\rho_{v 2}^{\prime}\right)_{i}^{j} b_{v 2}}
$$

and

7 


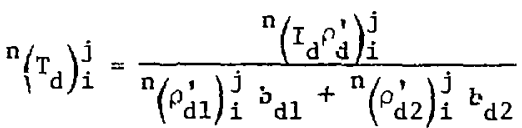

Because the four spectfic heat coefficients that appear are presently constants, we are relieved of having to store the two $T$ arrays. The constants $k_{v}$ and $k_{d}$ are heat conduction coeffictents. $E_{i}^{j}$ represents the energy contribution from some optional heat source, such as ciemical or nuclear processes.

The velocities appearing in the drag term in the ${ }^{\pi+l}\left(I_{v}\right)_{i}^{j}$ equation are calculated as

$\left(u_{d i}^{j}-u_{v i}^{j}\right)^{2} \equiv\left[\frac{1}{2}\left(u_{j i+\frac{1}{2}}^{j}+u_{d i-\frac{1}{2}}^{j}-u_{v i+\frac{1}{2}}^{j}-u_{v i-\frac{1}{2}}^{j}\right)\right]^{2}$

and

$\left(v_{d i}^{j}-v_{v i}^{j}\right)^{2} \equiv\left[\frac{1}{2}\left(v_{d i}^{j+\frac{1}{2}}+v_{d i}^{j-\frac{1}{2}}-v_{v i}^{j+\frac{1}{2}}-v_{v i}^{j-\frac{1}{2}}\right)\right]^{2}$.

When it becomes available, the new ${ }^{n+1} I_{v}$ yalue is useu to adjust the $A$ for use in Phase 2,

$A_{i}^{j}=A_{i}^{j n+1}\left(I_{v}\right)_{i}^{j} / I^{n}\left(I_{i}^{j}\right.$

The second major pass through the mesh in Phase $I$ is concerned with calculating a set of momentum fluxes, comprised of the four arrays $\left(\rho_{v}^{\prime} v_{v}\right), \overline{\left(\rho_{v}^{\prime} v\right)}$, $\left(\rho_{d}^{\prime} u_{d}\right)$, and $\left(\rho_{d}^{\prime} v_{d}\right)$. These fluxes are defined at th? same cell-edge positions as the velocities $u_{v}$, $v_{v}, u_{d}$, and $v_{d}$, respectively. While dealing with momentum, it is convenient simply to replace each velocity in computer storage by the corresponding momentum, which will be reconverted to a velocity in Phase 2. The four equations used are:

$\left(\rho_{v}^{\prime}{ }_{v}\right)_{i+t_{-2}}^{j}={ }^{n}\left(\rho_{v}^{\prime} u{ }_{v}\right)_{i+w_{2}}^{j}$

$$
\begin{aligned}
& +\frac{\delta t}{r_{i+\frac{1}{2}} \delta r}\left[{ }^{n}\left\langle\rho_{v}^{\prime} u_{v}{ }^{2} r\right\rangle_{i}^{j}-{ }^{n}\left\langle\rho_{v}^{\prime} u_{v}{ }^{2} r\right\rangle_{i+1}^{j}\right] \\
& +\delta t{ }^{n}\left(F_{v r}\right)_{i+\frac{j}{2}}^{j}
\end{aligned}
$$

$$
\begin{aligned}
& \left.+\frac{\delta t}{\delta z}\left[{ }^{n}\left\langle\rho_{v}^{\prime} u_{v} v_{v}\right\rangle\right\rangle_{i+l / 2}^{j-l / 2}-n\left\langle\rho_{v}^{\prime} u_{v} v_{v}\right\rangle_{i+\frac{1}{2}}^{j+\frac{l}{2}}\right], \\
& \left(\rho_{v}^{\prime} v{ }_{i}^{j+\mu_{2}}={ }^{n}\left(\rho_{v}^{\prime} v\right)_{i}^{j+l_{2}}\right. \\
& +\frac{\delta t}{r_{j} \delta r}\left[\left\langle\rho_{v} u_{v} v_{v} r\right\rangle_{i-\frac{1}{2}}^{j+\frac{1}{2}}-n\left\langle\rho_{v}^{\prime} u_{v} v_{v} r\right\rangle_{i+1 / 2}^{j+\mu_{2}}\right] \\
& +\delta t^{n}\left(F_{v z}\right)_{i}^{j+\frac{1}{2}} \\
& +\frac{\delta t}{\delta z}\left[{ }^{n}\left\langle\rho_{v}^{\prime} v_{v}^{2}\right\rangle{ }_{i}^{j}-\left\langle\rho_{v}^{\prime} v_{v}^{2}\right\rangle_{i}^{j+1}\right]+\left(\rho_{v}^{\prime}\right)_{i}^{j+\frac{1}{2}} g \delta t, \\
& \left(\rho_{d}^{\prime} u_{d}\right)_{i+\frac{1}{2}}^{j}={ }^{n}\left(\rho_{d}^{\prime} u_{d}\right)_{i+\frac{1}{2}}^{j} \\
& +\frac{j t}{r_{i+\frac{1}{2}} \delta r}\left[{ }^{n}\left\langle\rho_{d}^{\prime} u_{d}{ }^{2} r\right\rangle_{i}^{j}-{ }^{n}\left\langle\rho_{d}^{\prime} u_{d}{ }^{2} r\right\rangle_{i+1}^{j}\right] \\
& +\delta t^{n}\left(F_{d r}\right)_{i+\frac{1}{2}}^{j} \\
& +\frac{\delta L}{\delta z}\left[{ }^{n}\left\langle\rho_{d}^{\prime} u_{d} v_{d}\right\rangle_{i+\frac{1}{2}}^{j-\frac{1}{2}}-{ }^{n}\left\langle\rho_{d}^{\prime} u_{d} v_{d}\right\rangle_{i+\frac{1}{2}}^{j+\frac{1}{2}}\right],
\end{aligned}
$$

and

$$
\begin{aligned}
& \overline{\left(\rho_{d}^{\prime} v_{d}\right)_{i}^{j+\frac{1}{2}}=n}\left(\rho_{d}^{\prime} v_{d}\right)_{i}^{i+\frac{1}{2}} \\
& +\frac{\delta t}{r_{i} \delta r}\left[n\left\langle\rho_{d}^{\prime} u_{d} v_{d} r\right\rangle_{i-\frac{1}{2}}^{j+l_{1 / 2}}-n\left\langle\rho_{d}^{\prime} u_{d} v_{d} r\right\rangle_{i+\frac{1}{2}}^{j+\frac{d}{2}}\right] \\
& +\delta t^{n}\left(F_{d z}\right)_{i}^{j+\frac{1}{2}} \\
& +\frac{\delta t}{\delta z}\left[{ }^{n}\left\langle\rho_{d}^{\prime} v_{d}{ }^{2}\right\rangle_{i}^{j}-{ }^{n}\left\langle\rho_{d}^{\prime} v_{d}{ }^{2}\right\rangle_{i}^{j-1}\right]+\left(\rho_{d}^{\prime}\right)_{i}^{j+d / 2} g \delta c .
\end{aligned}
$$

The donor-cell formulations in the cinvective flux terms are analogous to those previously described for the quantities in the first sweep, but, because the centerings of the variables involved are different, we include several representative examples. In the $\overline{\rho u}$ equations: 
$\left\langle\rho u^{2} r\right\rangle_{j}^{j}=(u r)_{i}^{j}\left[\left(\frac{1}{2}+\xi\right)(\rho u)_{i-\frac{1}{2}}^{j}+\left(\frac{1}{-1}-\xi\right)(\nu u)_{i+\frac{1}{2}}^{j}\right]$,

where

$\xi=\beta_{0}\left(\frac{u_{i}^{j} \delta t}{\delta r}\right)+\alpha_{0} \operatorname{sign}\left(u_{i}^{j}\right)$,

and

$u_{i}^{j}=\frac{1}{2}\left(u_{i+\frac{1}{2}}^{j}+u_{i-\frac{1}{2}}^{j}\right)$.

$\langle\rho u v\rangle_{i+\frac{1}{2}}^{j-\frac{1}{2}}=v_{i+\frac{1}{2}}^{j-\frac{1}{2}}\left|\left(\frac{l}{2}+\xi\right)(\rho u)_{i+\frac{1}{2}}^{j-1}+\left(\frac{1}{2}-\xi\right)(\rho u)_{i+\frac{1}{2}}^{j}\right|$,

where

$\xi=\beta_{0}\left(\frac{v_{i+1}^{j-\frac{1}{2}} \delta t}{\partial z}\right)+\alpha_{0} \operatorname{sign}\left(v_{i+\frac{1}{2}}^{j-\frac{1}{2}}\right)$,

and

$v_{i+\frac{1}{2}}^{j-\frac{1}{2}}=\frac{1}{2}\left(v_{i}^{j-\frac{1}{2}}+v_{i+1}^{j-\frac{i}{2}}\right)$

In the $\overline{p v}$ equations:

$\langle\rho u v r\rangle_{i-\frac{1}{2}}^{j+\frac{1}{2}}=u_{i-\frac{1}{2}}^{j+\frac{1}{2}} r_{i-\frac{1}{2}}\left[\left(\frac{1}{2}+\xi\right)(\rho v)_{i-1}^{j+\frac{1}{2}}+\left(\frac{1}{2}-\xi\right)(\rho v)_{i}^{j+\frac{1}{2}}\right]$,

where

$\xi=\beta_{o}\left(\frac{u_{i-1 / 2}^{j+\frac{1}{2} \delta} t}{\delta r}\right)+\alpha_{o} \operatorname{sign}\left(u_{i-\frac{1}{2}}^{j+\frac{1}{2}}\right)$,

and

$u_{i-\frac{1}{2}}^{j+\frac{1}{2}}=\frac{1}{2}\left(u_{i-\frac{1}{2}}^{j}+u_{i-\frac{1}{2}}^{j+1}\right)$.

In addition to the convective flux terms, the $\overline{\rho v}$ equations contain terms for including the ef fect or gravitational acceleration, with $g$ being constant.

In many KACHINA applications, the flows to be studied will involve interaction with some confining and at least partially nonfalling structural elements, which may not be practical to include in the computer model in complete detail. Such interactions may be significantly nonisotropic in orientation. To properly incorporate their effects will require inseraction terms with material strergth effects capable of representing added inertia, nonisotropic drag, energy dissipation, and elastic-plastic deformation. In the present KACHINA version, the $F_{r}$ and $F_{z}$ terms in the momentum equations represent a simple preliminary approach to including nonisotropic effects. The.ie terms contribute a dissipationless turning that tends to constrict motion primarily to the axial direction. The direction of the force is orthogonal to the velocity, and the streagth is proportional to the departure of the velocity from the axial direction. Thus, if

$\vec{u}=\hat{i} u+\hat{j} v$,

and

$\vec{F}=\hat{i} a+\hat{j} b$,

then

$a u+b v=0$,

and

$a^{2}+b^{2}=\varepsilon^{2} u^{2} /\left(u^{2}+v^{2}\right)$,

with magnitude proportional to $|\mathrm{u}|$.

Therefore,

$a= \pm E u v /\left(u^{2}+v^{2}\right)$,

and

$b=\mp E u^{2} /\left(u^{2}+v^{2}\right)$,

or

$a=-E u v \operatorname{sign}(v) /\left(u^{2}+v^{2}\right)$,

and

$b=+\varepsilon u^{2} \operatorname{sign}(v) /\left(u^{2}+v^{2}\right)$. 
Because $v$ sign ( $v$ ) is always positive ( $|\mathrm{v}|)$, a is always directed against $u$, whereas $b$ works to increase positive $v$ or to decrease nerative $v$. Our form for the nonisotropic term in this version of KACHINA is

$\vec{F}=-\frac{E_{\ell} u_{\ell} \operatorname{sign}\left(v_{\ell}\right)}{u_{\ell}^{2}+v_{\ell}^{2}}\left(\hat{i v v_{\ell}}-\hat{j} u_{\ell}\right)$,

where $\ell^{\prime}=\mathrm{d}$ or $\mathrm{v}$, thereby requiring a different $\varepsilon$ for the term in a droplet equation from that in a vapor equation. With $F_{r}=a$ and $F_{z}=b$, the equations used are:

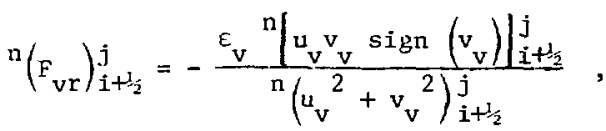

$n\left(F_{d r}\right)_{i+\frac{1}{2}}^{j}=-\frac{\varepsilon_{d}{ }^{n}\left(\left.u_{d} v_{d} \operatorname{sign}\left(v_{d}\right)\right|_{i+1 / 2} ^{j}\right.}{n\left(u_{d}{ }^{2}+v_{d}{ }^{2}\right)_{i+\frac{1}{2}}^{j}}$,

$n(F v z)_{i}^{j+\frac{1}{2}}=+\frac{\varepsilon_{v} n\left(u_{v}^{2} \operatorname{sign}\left(v_{v}\right)\right]_{i}^{j+\frac{1}{2}}}{n\left(u_{v}^{2}+v_{v}^{2}\right)_{i}^{j+\frac{1}{2}}}$,

and

$n\left(F_{d z}\right)_{i}^{j+\frac{1}{2}}=+\frac{\varepsilon_{d} n\left[u_{d}^{2} \operatorname{sign}\left(v_{d}\right)\right]_{i}^{j+\frac{1}{2}}}{n\left(1_{d}^{2}+v_{d}^{2}\right)_{i}^{j+\frac{1}{2}}}$.

Generally, $\varepsilon_{\ell}(r, z, l)$ may be prescribed in its $r-z$ variations, and $\varepsilon_{\ell}$ may decay during the course of a calculation, representing the loss of integrity of the confining structure. At present, however, we simply specify $\varepsilon_{\mathrm{v}}$ and $\varepsilon_{\mathrm{d}}$ as constants. Note that if $E_{v}$ or $\varepsilon_{d}$ is large, the corresponding term may require an implicit treatment to ensure that all motions are constrained to the desired trajectory.

Further, this nonisotropic force cannot be incorporated into the drag term, berause it includes the effects of droplets colliding with other droplets that are constrained into axial channels by material strength, and such collisions are precluded by our two-field approach.

Noce that this version of the momentum equations omits all viscous tarms because they are required neither for numerical stability (because of our partial donor-cell convection treatment), nor for the physical processes that we wish to represent in this initial version of the code. Their later inclusion will be accomplished entirely by addition of the appropriate stress terms to those equations defining the $\overline{\rho u}$ and $\overline{\rho v}$ quantities.

This completes the explicit part of the calculation cycle. In summary, at the end of Phase 1 , we have in computer storage the $n+1$ values of $\rho_{d}^{\prime}, \rho_{d 1}^{\prime}$, $\theta, I_{v}$, and $I_{d}$, along with the values of $n_{\rho_{v}^{\prime}}^{\prime}, n_{\rho_{v 1}^{\prime}}^{\prime}$, $A, \widetilde{p}, K,\left(\overline{\rho_{v}^{\prime} u_{v}}\right),\left(\overline{\rho_{v}^{\prime} v_{v}}\right),\left(\overline{\rho_{d}^{\prime} u_{d}}\right)$, and $\left(\overline{\rho_{d}^{\prime} v_{d}}\right)$.

\section{Phase 2-Implicit Calculations}

The Phase 2 calculations start with conversion of the momenta from Phase 1 back into velocity components $\widetilde{u}_{v}, \widetilde{v}_{v}, \widetilde{u}_{d}$, and $\widetilde{v}_{d}$. These are the tentative final velocities for the cycle, as symbolized by the tildes, and they include the first-guess effects of pressure acceleration and drag, both of which will be corrected as the tiide velocities converge to their final values for the cycle. The velocities are given by the (explicit) expressions:

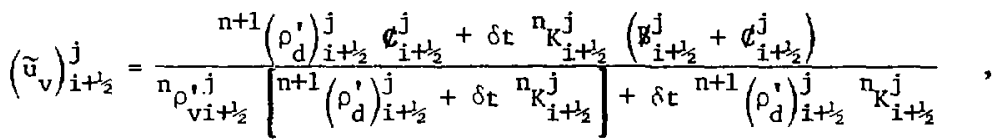

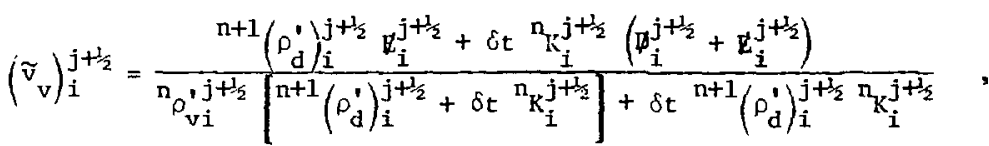




$$
\begin{aligned}
& \left(\widetilde{u}_{d}\right)_{i+\frac{1}{2}}^{j}=\frac{{ }^{n}\left(\rho_{v}^{\prime}\right)_{i+\frac{1}{2}}^{j} b_{i+\frac{1}{2}}^{j}+\delta t{ }^{n_{k}} k_{i+\frac{1}{2}}^{j}\left(p_{i+\frac{1}{2}}^{j}+q_{i+\frac{1}{2}}^{j}\right)}{n_{\rho_{v i+\frac{1}{2}}^{\prime j}}^{j}\left[{ }^{n+1}\left(\rho_{d}^{\prime}\right)_{i+\frac{1}{2}}^{j}+\delta t{ }^{n} k_{i+\frac{1}{2}}^{j}\right]+\delta t^{n+1}\left(\rho_{d}^{\prime}\right)_{i+\frac{1}{2}}^{j}{ }^{n} k_{i+\frac{1}{2}}^{j}},
\end{aligned}
$$

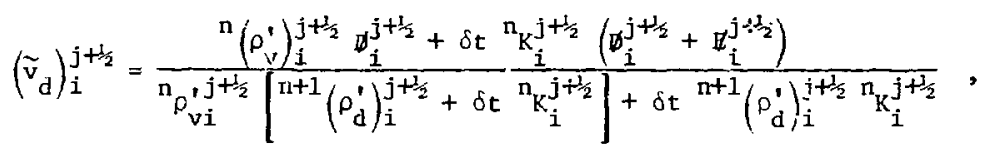

where:

$$
\begin{aligned}
& \vec{p}_{i+\frac{1}{2}}^{j}=\left(\hat{\rho}_{d}^{\prime} u_{d}\right)_{i+\frac{1}{2}}^{j}+\left(1-{ }^{n+1} \theta_{i+\frac{l}{2}}^{j}\right) \frac{\delta t}{\delta r}\left(\tilde{p}_{i}^{j}-\tilde{p}_{i+1}^{j}\right), \\
& q_{i+\frac{1}{2}}^{j}=\overline{\left(p_{v}^{u}\right)_{i+\frac{1}{2}}^{j}}+{ }^{n+1} \theta_{i+\frac{1}{2}}^{j} \frac{\delta t}{\delta r}\left(\tilde{p}_{i}^{j}-\widetilde{p}_{i+1}^{j}\right), \\
& \not b_{i}^{j+\frac{1}{2}}=\left(\rho_{d}^{i} v_{d}\right)_{i}^{j+\frac{1}{2}}+\left(1-{ }^{n+1} \theta_{i}^{j+\frac{1}{2}}\right) \frac{\delta t}{\delta z}\left(\widehat{p}_{i}^{j}-\tilde{p}_{i}^{j+1}\right), \\
& \mathbb{k}_{i}^{j+\frac{d}{2}}=\left(\rho_{v}^{\prime} v\right)_{i}^{j+\frac{1}{2}}+{ }^{n+1} \theta_{i}^{j+\frac{1}{2}} \frac{\delta t}{\delta z}\left(\tilde{p}_{i}^{j}-\tilde{p}_{i}^{j+1}\right)
\end{aligned}
$$

An implicit treatment is now required to help increase computational stability, in particular to eliminate the usual courant-like restriction on high sound speed, by allowing signals to traverse more than one cell per time step. This is accomplished by iterating the quantities $\tilde{p}_{,} \tilde{\rho}_{v}^{\prime}, \widetilde{u}_{v}, \widetilde{v}_{v}: \widetilde{u}_{d}$, and $\widetilde{v}_{d}$ to obtair new velocities that have been accelerated with time-advanced pressure gradients. The new velocities jepend on the new pressures and densities, which, in turn, depend on the velocities; therefore the technique is implicit. It is best solved by an iterative process to provide the generality of initial ard boundary conditions that usually are precluded by direct solution techniques.

The final $(n+1)$ values of $p$ are accumulated from the tilde values, in which each iteration contributes an increment to $\widetilde{p}$, designated $b ; s p$.

The source term for the iteration is labeled $\widetilde{\mathrm{D}}$; it is composed of a $\partial \rho_{\mathrm{v}}^{\prime} / \partial t$ term plus a $\nabla \cdot\left(\dot{\rho}^{-2}\right)$ term, both of which use the most recently updated t.ilde values:

$$
\begin{aligned}
\widetilde{D}_{i}^{j} & =\frac{1}{\delta t}\left[\left(\tilde{\rho}_{v}^{\prime}\right)_{i}^{j}-{ }^{n}\left(\rho_{v}^{\prime}\right)_{i}^{j}\right] \\
& +\frac{1}{r_{i} \delta r}\left[\left\langle\tilde{\rho}_{v}^{\prime} \tilde{u}_{v} r\right\rangle_{i+\frac{1}{2}}^{j}-\left\langle\tilde{\rho}_{v}^{\prime} \tilde{u}_{v} r\right\rangle_{i-\frac{1}{2}}^{j}\right] \\
& +\frac{1}{\delta z}\left[\left\langle\tilde{\rho}_{v}^{\prime} \tilde{v}_{v}\right\rangle_{i}^{j+\frac{1}{2}}-\left\langle\tilde{\rho}_{v}^{\prime} \tilde{v}_{v}\right\rangle_{i}^{j-1 / 2}\right] .
\end{aligned}
$$

Note that two levels of the tocal vapor density $\rho_{v}^{\prime}$ must be maintained throughout this iterative process, as indicated in the first term of $\widetilde{D}$. The donor-cell formulation ..f the second and third terms of $\tilde{D}$ is calculated in a manner similar to that used in Phase 1. For example,

$$
\left\langle\tilde{\rho}_{v}^{\prime} \tilde{u}_{v} r\right\rangle_{i+t_{2}}^{j}=\left(u_{v} r\right)_{i+\frac{1}{j}}^{j}\left[\left(\frac{1}{2}+\xi\right)\left(\tilde{\rho}_{v}^{\prime}\right)_{i}^{j}+\left(-\frac{1}{2}-\xi\right)\left(\tilde{\rho}_{v}^{\prime}\right)_{i \cdot+1}^{j}\right],
$$

in which

$\xi=\beta_{0}\left[\frac{\left.\left(\widetilde{u}_{v}\right)^{j}\right)_{i+\frac{1}{2}}^{j} \delta t}{\delta r}\right]+\alpha_{0}\left[\operatorname{sign}\left(\tilde{u}_{v}\right)_{i+\frac{1}{2}}^{j}\right]$

The necessary pressurp change for the cell is given by

$\delta p_{i}^{j}=-\omega_{p}\left(\beta_{p} \widetilde{D}\right)_{i}^{j}$

in which $\omega_{p}$ is an under- or overrelaxation coefficient of order unity. Straight relaxation is given by $\omega_{p}=1$, but, because we are using a relaxation procedure based on Jacobl's method, the iteration will converge only if $0<\omega_{p} \leqslant 1$. Also, 


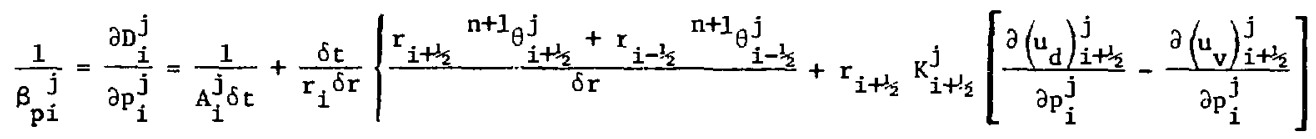

$$
\begin{aligned}
& \left.-r_{i-\frac{1}{2}} k_{i-\frac{1}{2}}^{j}\left[\frac{\partial\left(u_{d}\right)_{i-\frac{i}{2}}^{j}}{\partial p_{i}^{j}}-\frac{\partial\left(u_{v}\right)_{i-\frac{1}{2}}^{j}}{\partial p_{i}^{j}}\right]\right\}+\frac{\delta t}{\delta z}\left\{\frac{{ }^{n+1} \theta_{i}^{j+\frac{1}{2}}+{ }^{n+1} \theta_{i}^{j-\frac{1}{2}}}{\delta z}+k_{i}^{j+\frac{1}{2}}\left[\frac{\partial\left(v_{d}\right)_{j}^{j+\frac{1}{2}}}{\partial p_{i}^{j}}-\frac{\partial\left(v_{v}\right)_{i}^{j+\frac{1}{2}}}{\partial p_{i}^{j}}\right]\right. \\
& \left.-k_{i}^{j-\frac{1}{2}}\left[\frac{\partial\left(v_{d}\right)_{i}^{j-\frac{1}{2}}}{\partial p_{i}^{j}}-\frac{\partial\left(v_{v}\right)_{i}^{j-\frac{1}{2}}}{\partial p_{i}^{j}}\right]\right\},
\end{aligned}
$$

in which the partial derivatives are calculated by means of the following equations. Note that the second and fourth equations are not obtained merely by index changes from the first and third equations.

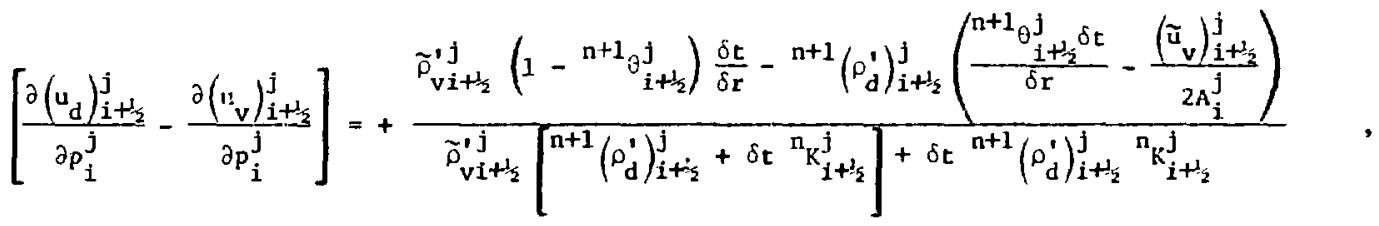

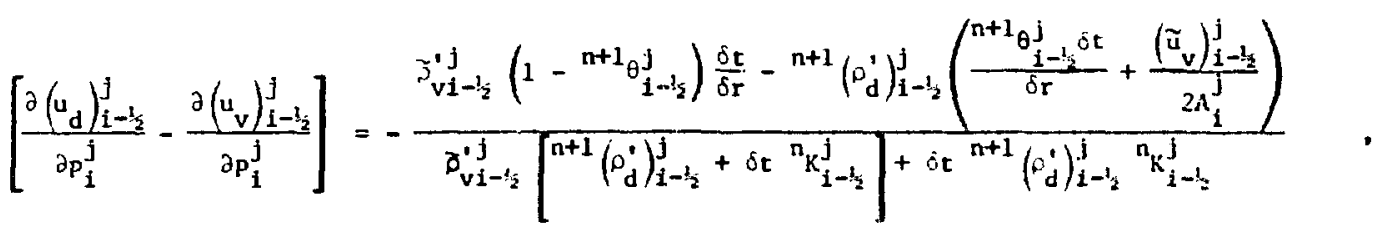

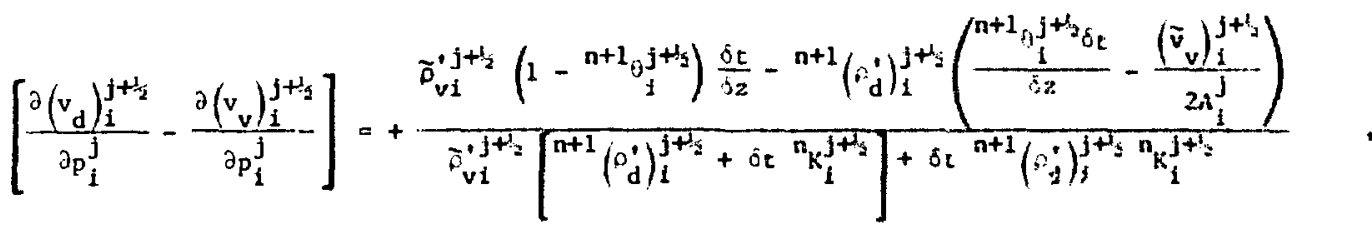

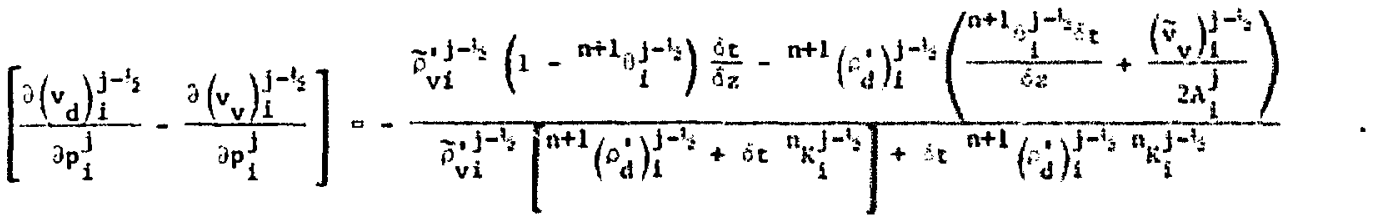

We have found that it is sufficient to calculate an array of ph for all wells and abote these before caber-

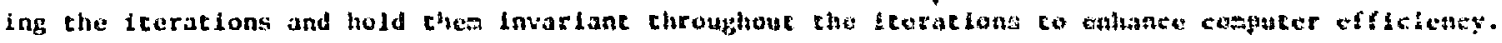
With $s_{i}$ calcisated, the neat step is to updace and

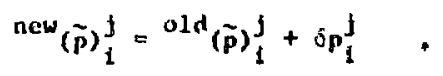

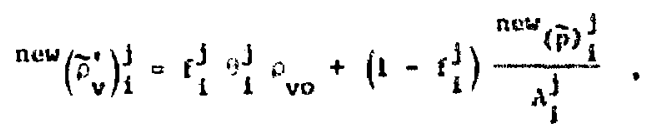


thus allowing direct calculation of the new velocity values:

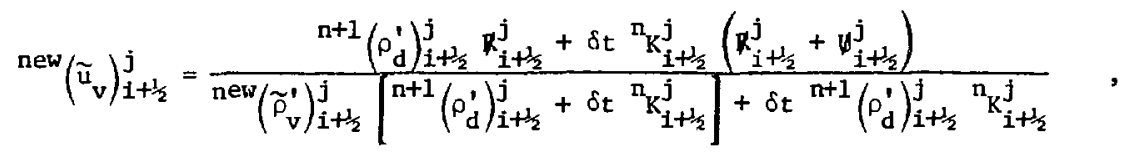

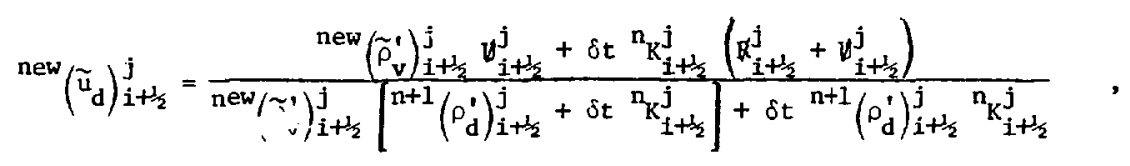

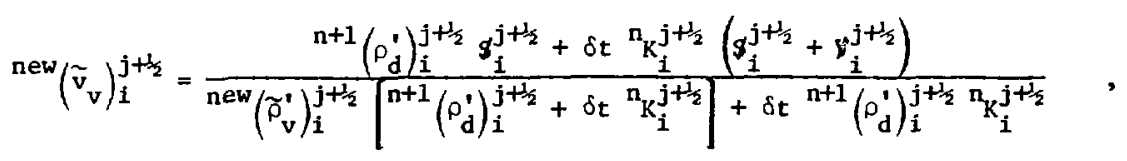

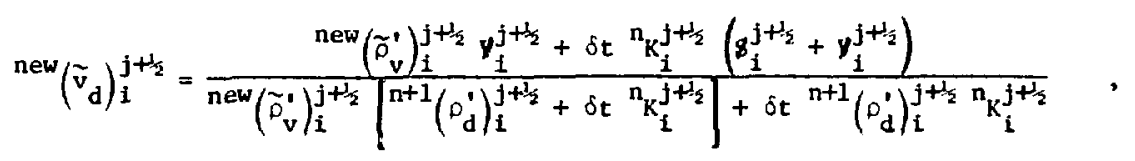

where

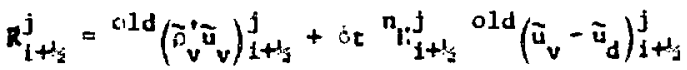

$$
\begin{aligned}
& +\frac{s t\left(s p_{i}^{j}-s p_{1+1}^{j}\right)}{s r} n+1, j
\end{aligned}
$$

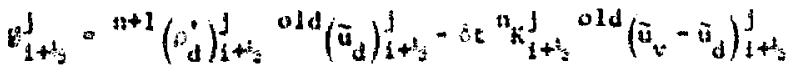

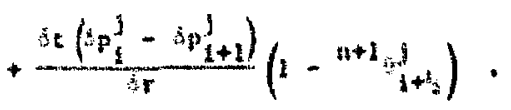

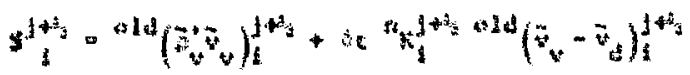

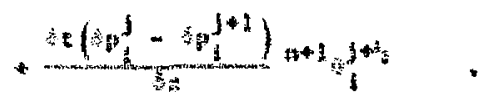

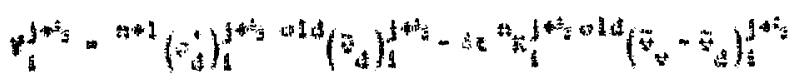

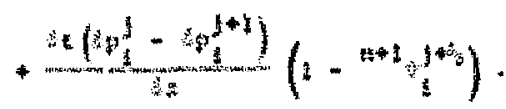

Each Iteracion consists of two sweeps over the entire mesh; the first sweep provides ${ }^{\text {new }} \overline{\mathrm{p}}$ for all cellz. then the second sweep calculates updated values of $\bar{v}_{v}, \bar{u}_{v}, \bar{u}_{d}, \bar{v}_{v}$, and $\bar{v}_{d}$ for all cells. This two-sweep-per-1teration procedure is required because the neighboring values of o $p_{i+1}^{j}$ and $\delta p_{1}^{j+1}$ must be available for the $A, t, y$, and equations. The steration procedure is repeated unet

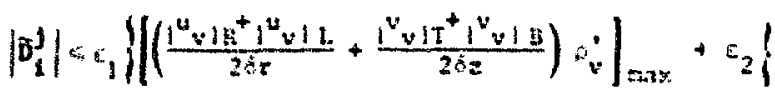

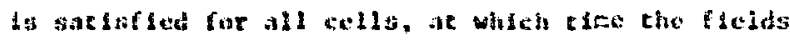

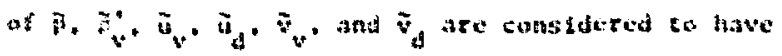

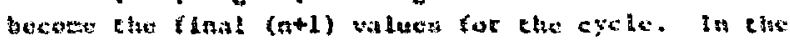

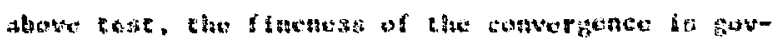

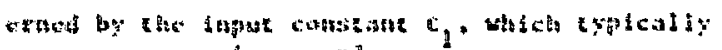

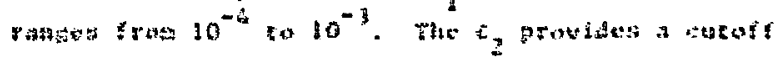
axta

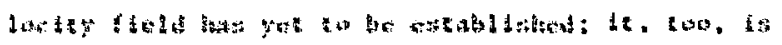

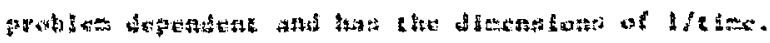

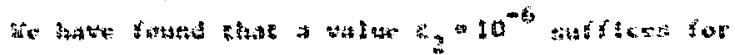

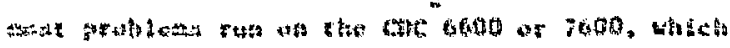
caty

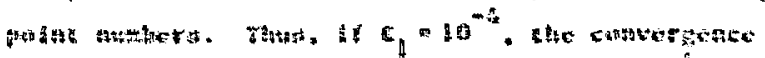

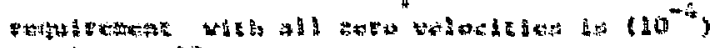

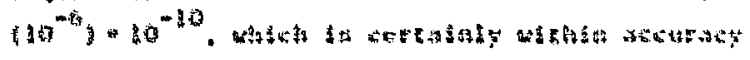


standards, but if $\varepsilon_{2}$ were reduced to $10^{-10}$, however, the resulting $10^{-14^{2}}$ would border on machine significance, and convergence could not be obtained. The [ $\int_{\max }$ portion of the convergence test above represents the magnitude of the largest initial tilde velocity times $\rho_{v}^{\prime}$ product in the entire mesh, found upon an examination of all cells that was performed concurrently with the $\beta_{p}$ calculation, back before the iteration began.

In practice, it is wise to specify some maximum allowable number of iterations per cycle, simply terminating the iterative process if this number is ever reached, and considering the current values of $\tilde{p}, \tilde{\rho}_{v}^{\prime}, \tilde{u}_{v}, \tilde{u}_{d}, \widetilde{v}_{v}$, and $\tilde{v}_{d}$ to be satisfactory. In our test runs, this procedure has worked well with a cutoff of 100 iterations. If the cutcff is encountered because the solution is diverging, obviously the calculation is in serious trouble, but the cutoff will occasionally terminate an iteration that is converging properly. In such instances, computer time is saved by this termination, and the current pressure, density, and velocity values are accurate enough that the iteration can be expected to converge more rapidly in the next eycle. Typical runs encounter this cutoff only very rarely, the usual number of iterations per cycle seldom exceeding 10.

At the end of this iterative sclution, we have in computer storage the $n+1$ values of $\rho_{d}^{\prime}, \rho_{d 1}^{\prime}, \theta$, $I_{v}, I_{d}, O_{v}^{\prime}, P, u_{v}, u_{d}, v_{v}$, and $v_{d}$, along with $A, K$, and ${ }^{n} \rho_{v 1}^{\prime}$. Because the new velocities are now available, we can solve for the one remaining unknown fleld variable, ${ }^{n+1} \rho_{v 1}^{\prime}$. We use a similar NewtonRaphson iteration scheme agaln, but this time based on the Gauss-seidel method. The first guess for $\tilde{\rho}_{v 1}^{\prime}$ is simply ${ }^{n} \rho_{v 1}^{\prime}$, and the changes are accumulated from the relacionship

$s\left(\tilde{\rho}_{v 1}^{\prime}\right)_{i}^{j}=-\omega_{p}\left(\beta_{\rho} Q\right)_{i}^{j}$

Here, $w_{\rho}$ is a relaxation coefficlent lying in the range $0<\omega_{p}<2$. The $\operatorname{term} B_{p}$ remains constant throughout this iteration, and is given by
The denominator in the $\beta_{\rho}$ equation will not vanish if $\mid u_{v} l_{\max } \delta t / \delta r<0.5$ and $\mid v_{v} l_{\max } \delta t / \delta z<0.5$. The source term $Q$ is continually recalculated using the latest values of $\widetilde{\rho}_{\mathrm{vl}}^{\mathrm{v}}$ :

$$
\begin{aligned}
Q_{i}^{j} & =\frac{\left(\widetilde{\rho}_{v 1}^{\prime}\right)_{i}^{j}-{ }^{n}\left(\rho_{v 1}^{\prime}\right)_{i}^{j}}{\delta t} \\
& +\frac{1}{r_{i} \delta r}\left[\left\langle{ }^{n+1} u_{v} r \tilde{\rho}_{v 1}^{\prime}\right\rangle_{i+\frac{1}{2}}^{j}-\left\langle{ }^{n+1} u_{v} r \tilde{\rho}_{v l}^{\prime}\right\rangle_{i-\frac{1}{2}}^{j}\right] \\
& +\frac{1}{\delta z}\left[\left\langle{ }^{n+1} v_{v} \tilde{\rho}_{v l}^{\prime}\right\rangle_{i}^{j+\frac{1}{2}}-\left\langle{ }^{n+1} v_{v} \tilde{\rho}_{v l}^{v}\right\rangle_{i}^{j-\frac{1}{2}}\right] .
\end{aligned}
$$

The $\tilde{\rho}_{\mathrm{vl}}^{\prime}$ values are iterated until $Q \approx 0$ for every cell, at which time the current $\widetilde{\rho}_{\mathrm{vl}}^{\prime}$ values are considered to have become the ${ }^{n+1} \rho_{\mathrm{vl}}^{\prime}$ values. In practice, we have found that $Q$ can be tested against the same convergence term used for the $\widetilde{D}$ test. Although $Q$ is analogous to $\widetilde{D}$ of the first iteration, and many of the same comments apply equally, one should note that the $n+1 u^{\prime} s$ and $v^{\prime}$ 's result solely from the first iteration and remain unchanged through this second iteration. The second and third terms in $Q_{i}^{j}$ are written in a manner like that used in the $\widetilde{D}$ equation. For example,

$$
\begin{aligned}
& \left\langle{ }^{n+1} u_{v} r \widetilde{\rho}_{v l}^{\prime}\right\rangle_{i+1 / 2}^{j} \\
& ={ }^{n+1}\left(u_{v}\right)_{i+1 / 2}^{j} r_{i+1 / 2}\left[\left(\frac{1}{2}+\xi\right)\left(\tilde{\rho}_{v 1}^{\prime}\right)_{i}^{j}+\left(\frac{1}{2}-\xi\right)\left(\tilde{\rho}_{v 1}^{\prime}\right)_{i+1}^{j}\right],
\end{aligned}
$$

in which

$\xi=\frac{\beta_{0} \delta t}{\delta r}\left[{ }^{n+1}\left(u_{v}\right)_{i+\frac{1}{2}}^{j}\right]+\alpha_{0} \operatorname{sign}\left[n+1\left(u_{v}\right)_{i+\frac{1}{2}}^{j}\right]$.

The solution of the second iteration completes the calculations associated with Phase 2, the implicit half of the cycle.

$$
\left(s_{b}\right)_{i}^{j}=\frac{1}{\frac{1}{\delta t}+\frac{1}{2 r_{1} \delta r}\left[{ }^{n+1}\left(r u_{v}\right)_{i+l_{2}}^{j}-{ }^{n+1}\left(r u_{v}\right)_{i-\frac{1}{2}}^{j}\right]+\frac{1}{2 \delta z}\left[{ }^{n+1}\left(v_{v}\right)_{i}^{j+\frac{1}{2}}-{ }^{n+1}\left(v_{v}\right)_{i}^{j-\frac{3}{2}}\right]} \text {. }
$$




\section{E. Boundary Conditions}

A variety of boundary conditions have been successfully tested in the KACHINA code. Figure 3 illustrates the currently available boundary options for the bottom, right, and top edges of the computing mesh, as specified by the input data for each particular problem. In all instances, the left boundary of the mesh serves as the axis of cylindrical symmetry. Typical configurations we have used include a box with three rigid free-slip walls, or the other extreme of three continuative out flow boundaries, in which the rigid section of the righthand wall has been reduced to zero height. A set of studies of fluidized dust beds used a specified inflow bottom boundary, a rigid right wall, and outflow along the top. On the right boundary, the transition point from rigiti free slip to outflow, noted in Fig. 3, can lie at any desired cell boundary from bottom to top, and it allows the extremes of an all-rigid freeslip boundary or an all-outflow boundary.

As Fig. 4 shows, the boundary conditions considered here are described in relation to the bottom boundary, the treatment being entirely analogous at the other boundaries. These conditions are more easily applied if the computing mesh shown in Fig. 1 is surrounded on all four sides by a belt of fictitious or outside cells. These cells provide convenient exterior storage locations for functions of

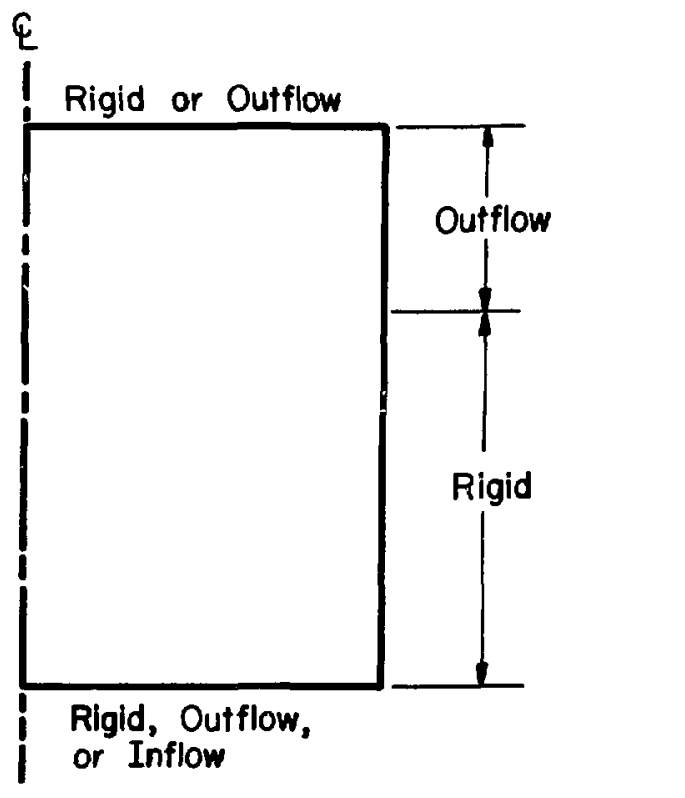

Fig. 3. Boundary conditions available in KACHINA.

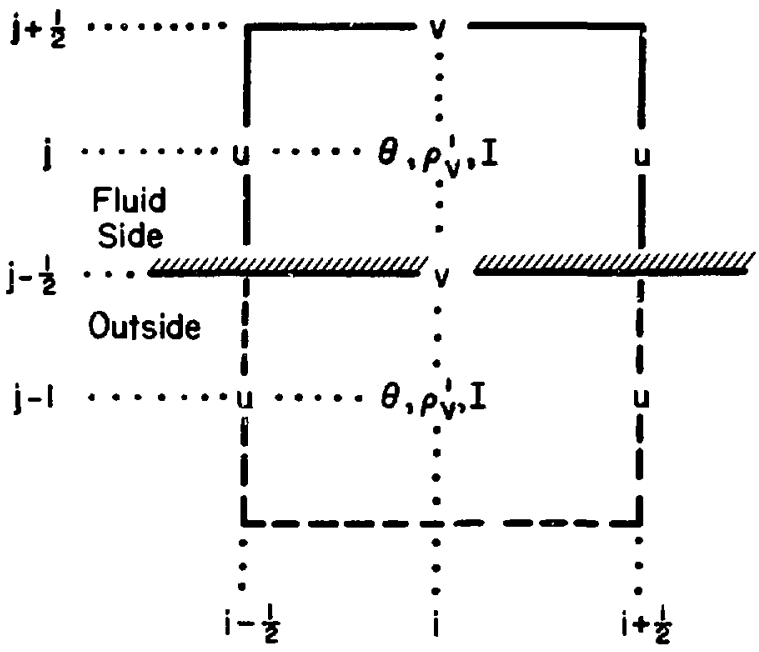

Fig. 4. Quantities invelved in boundary conditions at the bottom of the KACHINA mesh.

the neighboring inside cell variables, chosen so that when they are referenced in the equations the desired boundary condition is satisfied automatically without any testing of the boundary type.

(1) RIGID (FREE-SLIP): A rigld free-slip boundary represents an axis or plane of symmetry, or a nonadhering surface that exerts no drag upon the fluid. The normal component of velocity vanishes at the wall, and there is no gradient in scalar variables across the boundary. If the boundary is insulated:

$\theta_{i}^{j-1}=\theta_{i}^{j}$

$\left(v_{v}\right)_{i}^{j-\frac{1}{2}}=\left(v_{d}\right)_{i}^{j-\frac{1}{2}}=0$

$\left(\rho_{v 1}^{\prime}\right)_{i}^{j-1}=\left(\rho_{v 1}^{\prime}\right)_{i}^{j}$

$\left(\rho_{v}^{\prime}\right)_{i}^{j-1}=\left(\rho_{v}^{\prime}\right)_{i}^{j}$

$\left(I_{v}\right)_{1}^{j-1}=\left(I_{v}\right)_{1}^{j}$

(2) INFLOW (Specified): The inflow boundary allows vapor, only, to move into the system at a prescribed rate that, in principle, can vary with position and time, although in the present kichisi it is constant. 


$$
\begin{aligned}
& \theta_{i}^{j-1}=\theta_{\text {specified }} \\
& \left(v_{v}\right)_{i}^{j-\frac{1}{2}}=v_{\text {specified }}, \\
& \left(v_{d}\right)_{i}^{j-\frac{1}{1}}=\sigma, \\
& \left(\rho_{v 1}^{\prime}\right)_{i}^{j-1}=\theta_{\text {specified }}\left(\rho_{v 1}\right)_{\text {specified }}, \\
& \left(\rho_{v}^{\prime}\right)_{i}^{j-1}=\theta_{\text {specified }}\left(\rho_{v 1}+\rho_{v 2}\right)_{\text {specified }}, \\
& \left(I_{v}\right)_{i}^{j-1}=\left(I_{v}\right)_{\text {specified }} \cdot \\
& (3) \text { outflow (Continuative): A continuative }
\end{aligned}
$$
cutflow boundary allows fluid to leave the system at its own chosen rate, hopefully with minimal upstream flow disturbance whether the flow is subsonic or supersonic. Nothing precludes an outflow boundary from becoming a continuative inflow boundary (without spec'fication), should the velocity field at the boundary becone reversed. An example is shown in the final sample calculation discussed in Ref. 7:

$$
\begin{aligned}
& 9_{1}^{j-1}=\theta_{1}^{j} \\
& \left(v_{v}\right)_{i}^{j-l_{s}}=\left(v_{v}\right)_{i}^{j+l_{j}} \text {. } \\
& \left(v_{d}\right)_{1}^{j-1_{2}}=\left(v_{d}\right)_{1}^{j+l_{s}} \text {. } \\
& \left(\dot{v}_{v 1}^{\prime}\right)_{i}^{j-1}=\left(o_{v 1}^{\prime}\right)_{i}^{j} \\
& (\cdot v)_{i}^{j-1}-\left(\rho_{v}^{v}\right)_{i}^{j} . \\
& \left(z_{v}\right)_{i}^{j-1} \cdot\left(I_{v}\right)_{i}^{j} .
\end{aligned}
$$

For all three types of boundary conditions, chere is no gradient in droplet dengities or Internill culergies across the boundary:

$$
\begin{aligned}
& \left(\rho_{\mathrm{d} l}^{\prime}\right)_{i}^{j-1}=\left(\rho_{\mathrm{d} 1}^{\prime}\right)_{i}^{j}, \\
& \left(\rho_{\mathrm{d}}^{\prime}\right)_{i}^{j-1}=\left(\rho_{\mathrm{d}}^{\prime}\right)_{i}^{j}, \\
& \left(I_{d}\right)_{i}^{j-1}=\left(I_{d}\right)_{i}^{j},
\end{aligned}
$$

nor is there any gradient in the tangential component of velocity across the boundary:

$$
\begin{aligned}
& \left(u_{v}\right)_{i-\frac{1}{2}}^{j-1}=\left(u_{v}\right)_{i-\frac{1}{2}}^{j}, \\
& \left(u_{d}\right)_{i-\frac{1}{2}}^{j-1}=\left(u_{d}\right)_{i-\frac{1}{2}}^{j}, \\
& \left(u_{v}\right)_{i+\frac{1}{2}}^{j-1}=\left(u_{v}\right)_{i+\frac{1}{2}}^{j}, \\
& \left(u_{d}\right)_{i+\frac{1}{2}}^{j-1}=\left(u_{d}\right)_{i+\frac{1}{2}}^{j} .
\end{aligned}
$$

This specification of tangential velocity is required only for marker particle movement, discussed in Sec. II.E. Because there is no shear viscosity in this version of the code, the external tangential velocities are not otherwise referenced.

The momentum components in Phase 1 have values at the boundary that are based on the density and velocity of vapor or droplets, as appropriate, at that boundary position, in accordance with the above treatments.

The bcundary conditions are initially set in the problem setup. The exterior values of the explicit varisicles are reset in Phase 1 as the nelghboring fluid-side $n+1$ values become available. buring the pressure iteration In Phase 2, the exterfor values of $\bar{p}, \tilde{\rho}_{v}^{\prime}$, and the wall velocities are updated continuously to keep them appropriate to the continuously changing interior values, and $\rho_{\mathrm{vl}}^{\prime}$ is treated similarly in the second iteration.

Note that KACHINA requires no special pressure boundary conditions. This is a direct benefit of the Chorin-lite method ${ }^{10}$ chosen for the Phase 2 iteration procedure, which also contributes to efficiency and simplifteation of the solution process. 


\section{F. Sudden Incompressibility}

In certain flow situations, the vapor can be almost completely extruded from some cell or number of cells. We conclude that the droplets have come into rigid contact with one another, so that the $\overline{2}_{d}$ field has suddenly become essentially incompressible. An analogous situation is that of a set of billiard balls on a tabl.3, which may be moved about with great freedom until they are drawn together and racked into the triangle, whereupon they become tightly packed. The billiard balls may subsequently be separated and resume their previous freedom of movement; similarly, the flow that became so suddenly incompressible may open up again at some later time.

Sudden incompressibility must be allowed for and treated in a special manner in a multifield computing model; otherwise, the calculation will almost surely break down sooner or later. Fortunately, the void fraction will forewarn of the situation if it is carefully monitored on a cell-by-cell basis, as in such instances $\theta$ will become small. We test whether each ${ }^{n \cdot r l_{\theta}} \theta \theta_{0}$, whare the value $\theta_{0}=0.02$ has been found appropriate, at least for the test prob1 ams we have run. Usually, of course, ${ }^{n+1} \theta>\theta_{0}$, and the calculational procedure is the standard one described in the preceding sections. For thosecells In which ${ }^{n+1} \theta<\theta_{0}$, in principle the only modification required would be simply to force the velocity divergence to vanish by reducing the $\widetilde{D}$ equation in Phase 2 to a $\nabla \cdot \vec{u}_{d}=0$ expression. In KACHINA, we begin by setting ${ }^{n+1} \theta \equiv 0$, principally to make such cells highly visible In the numerical printout. Alternatively, we could leave $\theta$ at its calculated value, which would be the required procedure if $\theta_{0}$ were somewhat larger, as for example in a relatively porous bed of close-packed granules. In practice, there are actually several places in each of the two phases at which we change the computational procedure. In Phase 1:

(1) We set

$$
{ }^{n+1} 1_{i}^{j}=0
$$$$
\tilde{p}_{i}^{j}=n_{p_{i}}^{j}
$$$$
A_{1}^{j}=A_{\infty},
$$

$\mathrm{k}_{i}^{\mathrm{j}}=\mathrm{k}_{\infty}$

where $A_{\infty}$ and $K_{\infty}$ are some large numbers, say about $10^{10}$ times the ordinarily expected magnitudes of these quantities. The choice of time level $n+1$ for the $\theta$ 's appearing in the standard $K$ equation is dictated by the fact that when a suddenly incomprissible region opens up again, the restored confition ${ }^{n}+l_{\theta}>\theta_{0}$ will allow passing of this test and reestablishment of the standard procedure for the cell. However, ${ }^{n} \theta=0$ because of the previous state of the cell, and use of this old $f l a g$ as ${ }^{n} \theta$ in the $k$ equation would cause the computer to try a division by zero.

(2) In the ${ }^{n+1} I_{v}$ equacions, we eliminate two terms. The drag term is omitted on the assumption that $\vec{u}_{v}$ and $\vec{u}_{d}$ must be very closely tied together, and the work term is omitted because no work can be done on the vapor in such cells.

(3) Neither the momentum equations nor the initialization of the tilde velocities at the beginning of Phase 2 requires changing, because with $K=K_{\infty}$, the initializations force $\vec{u}_{v} \equiv \vec{u}_{d}$.

In Phase 2:

(4) Those ceils with ${ }^{n+1} \theta<\theta_{0}$ require different expressions for both $\beta_{p}$ and $\widetilde{\mathbf{E}}$ :

$$
\begin{aligned}
& \left(\beta_{p}\right)_{i}^{j} \equiv \frac{\delta r^{2} \delta z^{2}}{2 \delta t\left(\delta r^{2}+\delta z^{2}\right)}\left(\rho_{d}^{j}\right)_{i}^{j} \\
& \widetilde{D}_{i}^{j}=\frac{1}{r_{i} \delta r}\left[r_{i+\frac{1}{2}}\left(\tilde{u}_{d}\right)_{i+\frac{1}{j}}^{j}-r_{i-\frac{l}{2}}\left(\tilde{u}_{d}\right)_{i-\frac{1}{2}}^{j}\right] \\
& \quad+\frac{1}{\delta z}\left[\left(\widetilde{v}_{d}\right)_{i}^{j+\frac{1}{2}}-\left(\widetilde{v}_{d}\right)_{i}^{j-\frac{1}{2}}\right]
\end{aligned}
$$

Note that no consideration of donor-cell formulations arises in this $\nabla \cdot \vec{u}_{d}$ form of the $\overline{\mathbf{D}}$ equation.

(5) Neither the intermediate nor final values of pressure, density $\rho_{v}^{\prime}$, or velocity in Phase 2 require changing, As in (3) above, the equations will automatically provide ${ }_{u_{v}}^{\text {new }} \equiv{ }_{u_{d}}^{\text {new }}$, and they arrive at values that ensure $\nabla \cdot \vec{u}_{d}=0$ for those particular ce11s.

(6) The $\rho_{\mathrm{v} 1}^{\prime}$ iteration requires no changes. 


\section{THE KACHINA COMPUTING PROGRAM}

\section{A. General Structure}

KACHINA wis written for the CDC-7600, to provide a tool for several specific studies and for further methodology development. It embodies a number of features to make efficient use of computer storage and time, and it follows the better programming concepts, ill-defined but popularly called "structured programming," that have received so much attention recently. The basic KACHINA will be extended in several directions by a number of investigators, and its modular form has already worked successfully in other recent computing programs. The physical arrangement and the top-to-bottom flow in the coding correspond to the logical sequence of the computing cycle to the greatest degree practicable. The efficiency loss that results from writing the entire code in a higher level language rather than in machine language is hopefully counterbalanced by increased readability for most users and the simplification of adapting it in the future for use at other instaljations and for computers other than the CDC $-6000 / 7000$ series. Computing efficiency can be increased substantially by carefully rewriting the iteration sections in machine language, which we strongly recommend to anyone doing a significant amount of calculation with a FORTRAN program containing any iterative solutions.

As depicted in Fig. 5, KACHINA is built in an overlay fashion to minimize the use of Small Core Memory (SCM), the fast memory on the $\mathrm{CDC}-7600$. The main overlay $(0,0)$ always resides in SCM, and it contains the main controlling program, KACHINA. Subservient to it are the longer programs in the two primary overlays, $(1,0)$ and $(2,0)$, which reside on disk storage. KASET is the setup program, and KACHYDR performs the two-phase hydrodynamics described in Sec. I.

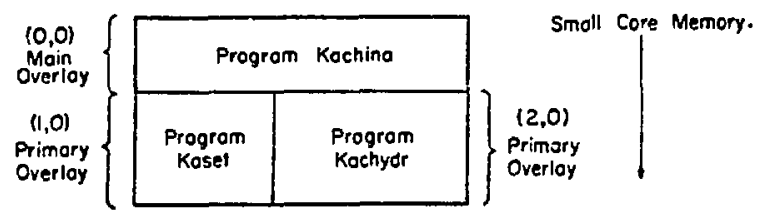

Fig. 5. The KACHINA three-program overlay structure.
The structure within each of these three prograns is further detailed in Fig. 6, which introduces the UPDATE notation used in the actual code.

In addition to the main program, KACHINA, the $(0,0)$ overlay contains the common $\mathrm{KSC}$, which is the SCM portion of the information written $\mathrm{cn}_{\mathrm{s}}$ tape for restarting purposes and is therefore the natural repusitory for all the SCM data that must be retained from cycle to cycle. Any subroutines that $\mathrm{nill}$ be referenced by the primary overlays should also be placed in $(0,0)$ to ensure that they are always resident in SCM and directly accessible by all programs. At present, LOOP is the only such subroutine; its function is described in Secs. II.C and II.D.

To set up a calculation from initial input data, the main program calls the $(1,0)$ overlay program KASET from the disk and surrenders control to it. This overlay is placed in SCM 1mmediately following the $(0,0)$ overlay. KASET itself is only a two-instruction program; it prints "SE SUP" to indicate that control has reached $(1,0)$, and then inumediately calls subroutine SETUP to perform the actual setup, creating the computing mesn with its initial cell quantities, and generating marker particles if chey KACHINA Code Structure

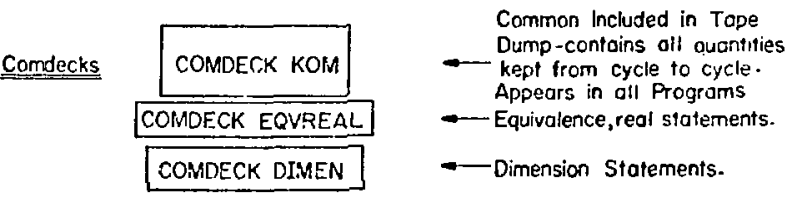

Overiay
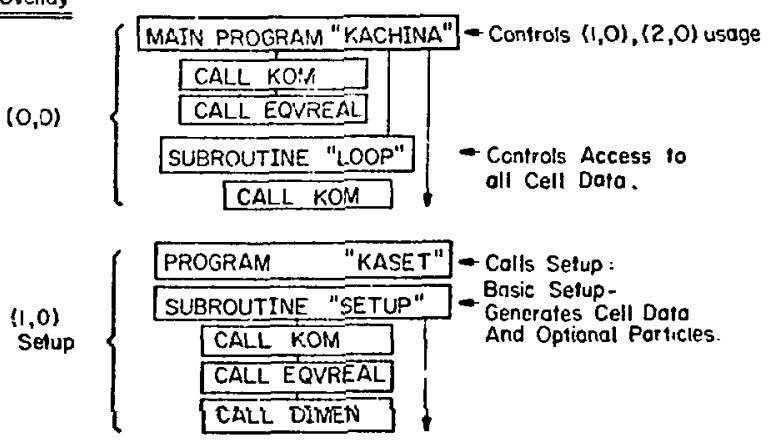

\begin{tabular}{|c|c|c|}
\hline \multirow{4}{*}{$\begin{array}{l}(2,0) \\
\text { Hydro }\end{array}$} & PROGRAM "KACHYDR" & \multirow{3}{*}{$\begin{array}{l}\text { - Calls Hydro: } \\
\text { 2-Phase Hydrodynamics } \\
\text { + Control Region ond } \\
\text { Particle Mover. }\end{array}$} \\
\hline & SUBROUTINE "HYORO" & \\
\hline & CALL KOM & \\
\hline & CALL EOVREAL & \\
\hline & CALL DIMAEN & \\
\hline
\end{tabular}

$F i_{b}, 6$. The KACHINA overlays, showing the functions of all sections and the UPDATE nomenclature. 
are specified. SECUP also sets boundary conditions for the edges of the mesh and determines parameters for microfilm plotting. When the problem setup is completed, SETUP returns control to the $; 0,0)$ main overlay program.

To ca.lculate after setting up, the main program calls the $(2,0)$ primary overlay KACHYDR from the disk and surrenders control to it. Because this overlay is of the same level as $(1,0)$, it covers the image of $(1,0)$ in SCM, as it is read in to the same locations following the $(0,0)$ overlay and thus allows reuse of the SCM space. Like KASET, KACHYDR is a two-instruction program: it prints "HYDRO" and immediately calls subroutine HYDRE. Should the job abort because of an unexpected error, the printed message allows the user to ascertain quickly which program he is in, whtch might otherwise be difficult inasmuch as the range of instruction addresses for both the $(1,0)$ and $(2,0)$ overlays starts at the same point.

HYDRO is the largest section of code in the computer program. It contains the two-phase hydrodynamics, the calculational cycles of which are repeated continuousiy under the direction of a "control region." This region is stracegically placed at the beginning of the subroutine, at which point in the cyclic process the quantities of greatest inrerest representing the solution at a given instant in problem time, are available. The control region provides all microfilm plots and numerical listings of cell data. It also increments the problem time $t$ by the current $\delta t$, performs tape dumps and tape restarts, and senses problem completion or an impending operating system time limit. In the latter two events, it returns control to the main program, which, in turn, always searches the input queue for further tasks. If there are none, the job is ended.

To restart a calculation from a tape dump, the main program bypasses the $(1,0)$ overlay and calls $(2,0)$ instead. HYL 20 senses the restart condition Immediately, and the control region reads the information from tape into memory and turns control over to the point in the calculation cycle that will continue the problem from where it left off when the tape dump was made.

\section{B. The Indexing Notation}

Figures 2 and 4 show that some variables are defined at cell centers and some at cell edges, as is typical of a number of Eulerian computing methods. In FORTRAN, one can represent $p_{i}^{j}$ simply by "P(I,J)," but $u_{i+\frac{1}{2}}^{i}$ cannot $b \geqslant 1$ ipresented by a "half-integer" index, so our convention is that " $U(I, J)$ " denotes this particular velocity. Thus the indices $I$ and $J$ denote a quantity located at the center of cell $(i, j)$, at the right edge $\left(i+\frac{1}{2}, j\right)$, or at the top edge $\left(i, j+\frac{1}{2}\right)$, depending on where the quantity is defined to be by the difference equations. In KACHINA, " $(I, J)$ " is replaced simply by "(IJ)," as only single subscrints are used for computer efficiency. In the KACHINA subscript notation, the letter "p" stands for "+," and "M" stands for "-." Thus, we write

$I J=(i, j)$,

$\mathrm{IMJ}=(i-1, j)$,

$I J M=(i, j-1)$,

IPJP $=(i+1, j+1)$,

etc.

Such a notation permits easy reading of programmed difference equations in the code. Figure 7 shows the siugle subscripts used to define ce:l quantities about a cell $(i, j)$.

As the number of cell edges in either direction is one greater than the number of cells, it is

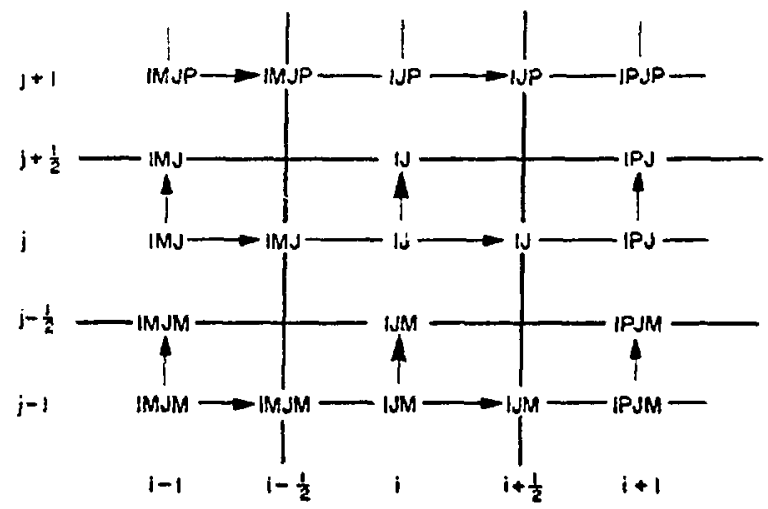

Fig. 7. Single-subscript notetion for cell and cell-edge quantities about cell $(i, j)$. 
apparent that the grid in computer storage must be at least $(\overline{\mathrm{I}}+1)$ by $(\bar{J}+1)$ in size. Because our indexing refers to cell centers and right and top edges, one extra column of storage on the left and one extra row along the bottom are provided. KACHINA also includes an extra row of cells across the top and an extra column up the right, giving a mesh that is $(\bar{I}+2)$ by $(\bar{J}+2)$ in extent. As described in Sec. I.E, these exterior zones are known as outside or fictitious celle, and surrounding the mesh with them helps in treating the boundary conditions.

An example of the actual KACHINA mesh for the virtual mesh of Fig. 1 is shown in Fig. 8, from which it is evident that double Do loops in FORTRAN to sweep all cell centers would have the limits $J=2$ to JPI and $I=2$ to IPI. Similarly, Do loops with 1 imits $J=2$ to $J P 1$ and $I=2$ to IBAR will access all interior u velocity components, and those with limits of $\mathrm{J}=2$ to JBAR and $I=2$ to IP1 will access all interior $v$ velocity components. Boundary velocithes $z$ ad exterior values of the cell-centered variables receive special treatment and are not normally included within the limits of the DO loops.

\section{Storage of Cel1 Data}

Although the present modest size of the code certainly doesn't warrant overlay construction, the basic KACHINA of this report has been built to allow for considerable expansion in two respects. First, calculations will become more finely resolved, implying use of several thousand computing cells. Second, more coding will be added to deal with other physical phenomena. This coding will include such features

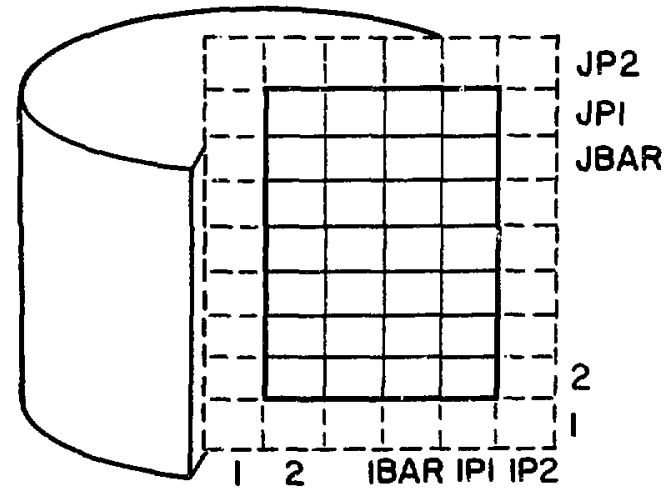

Fig. 8. KACHINA indexing scheme for the virtual mesh of Fig. 1, showing an example with many fewer cells than ordinarily are used for a calculation. as phase transttions, a third field, more realistic equations of state, chemical and nuclear processes, and better isotropic force treatments, to name mnly a few. Both these considerat:ons will greatly increase the demands on SCM space, and it is far better to allow for such growth in the initial architecture of a program than to have to add it later in some fashion that would require substantial rewriting to retain reasonable efficiency.

In addition to the overlay structure, KACHINA has several provisions for storage of cell data to allow efficient use of SCM. SCM requirements are significantly reduced by our use of only 19 storage words per cell, although the full calculation cycle requires 32 variables. Use of sn few storage words is ade possiule by retaining quantities during a cycle only as long as they are needed, and then using their storage words for other quantities. Figure 9 shows the allocation of the 19 storage words for a KACHINA cell in the $(1,0)$ and $(2,0)$ overlays. The ordering from left to right corresponds to the actual order in which quantitiss are calculated in the cote. A black dot indicates that the quantity currently in the given scorize word is referenced to calculate the quantity specified at the top of the column.

Note that before the iterations, the cell edge quantities $\delta \mathrm{tK}_{i+\frac{1}{2}}^{j}$ and $\delta \mathrm{tK}_{i}^{\mathrm{j}+\frac{1}{2}}$ and the cell quantity $\left(-\omega_{p} \beta_{p}\right)_{i}^{j}$ are formed, and that $A_{i}^{j}$ is converted to its reciprocal. Because all these quantities remain invariant in the iterative process, it is expedient to compute them throughout the mesh beforehand to avoid needless repetitive calculation within the iteration itself.

During the pressure iteration, ${ }^{n e w} \widetilde{p}$ replaces $\mathrm{old}_{\tilde{\mathrm{p}}}$ as soon as there is no further need to keep $\delta_{\mathrm{p}}$ available in memory. As the iterations are completed, the field values of $\widetilde{D}, K$, and $A$ are retrieved in case they are to be listed numerically in an output routine in the next pass through the control region. Also, $\tilde{\rho}_{v}^{\prime}$ replaces ${ }^{n} \rho_{v}^{\prime}$ in word 4 , becoming ${ }^{n+1} \rho_{v}^{\prime}$ by doing so, and similarly $\tilde{\rho}_{\mathrm{v} 1}^{\prime}$ replaces $\mathrm{n}_{\rho_{\mathrm{v} 1}^{\prime}}$ in word 2 , becoming ${ }^{n+1} \rho_{\mathrm{v} 1}^{\prime}$.

In the Phase 1 explicit calculations, the convection equations require neighboring values (on all four sides of the cell) of the variable being solved for. To maintain the correct time level (n) of these 


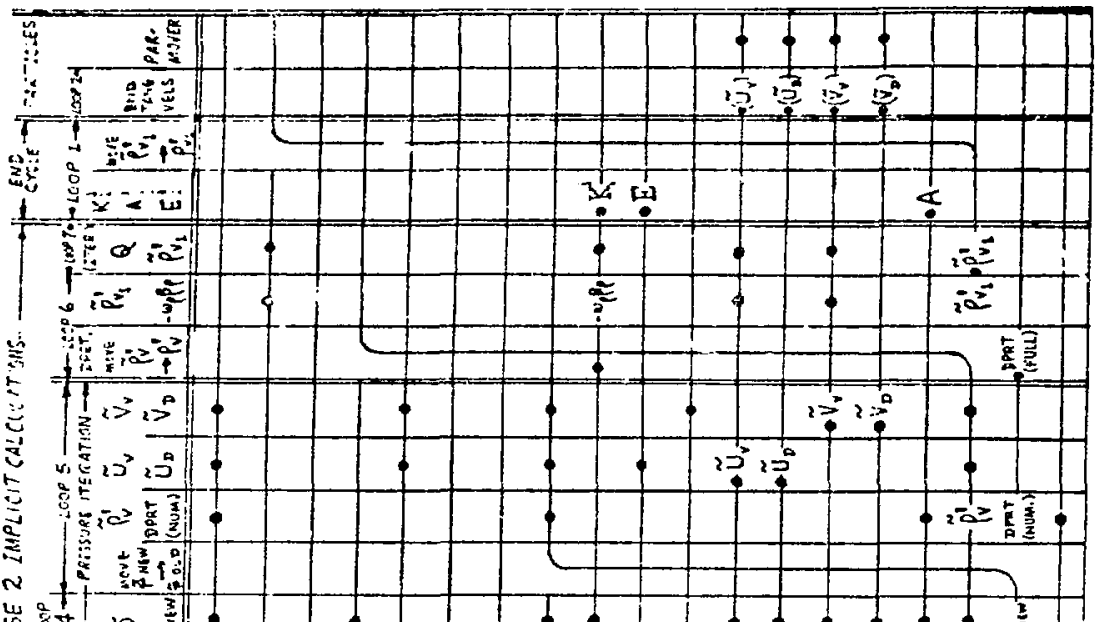

$\frac{+}{\frac{1}{9}}$

$w_{0}$ है $29 a^{\frac{3}{2}}$

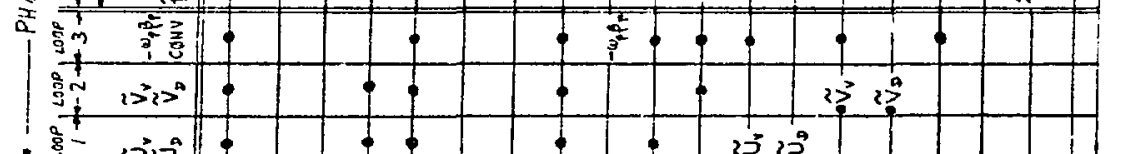

告

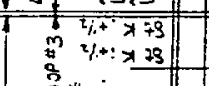

12

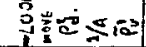

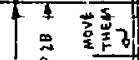
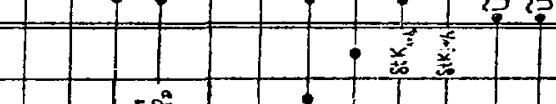

$+\int_{-i x^{2}}$

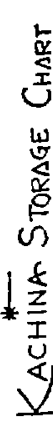
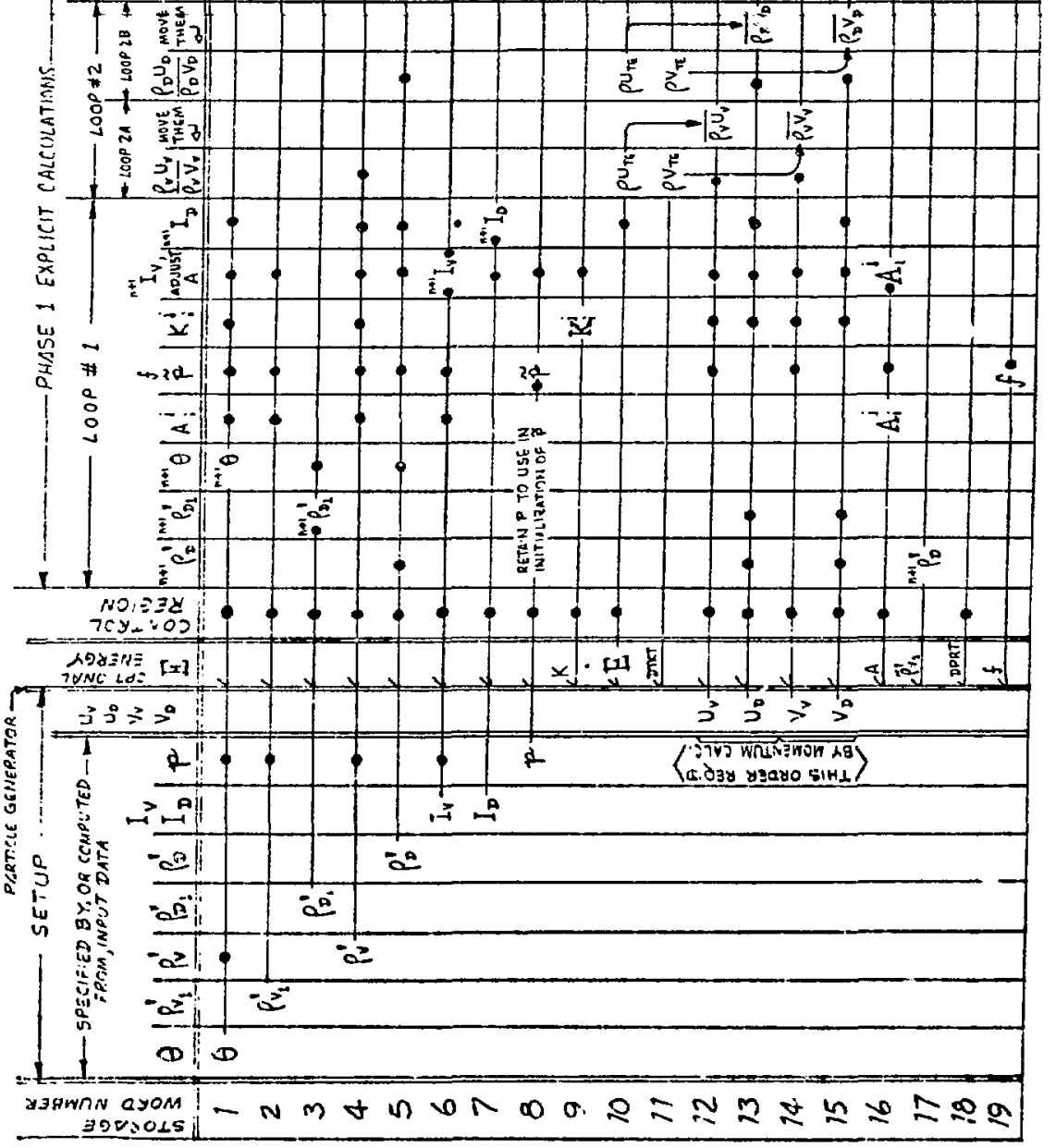

若

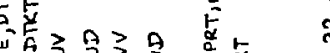

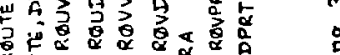

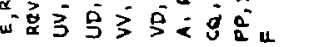
菌

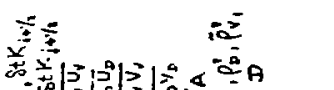

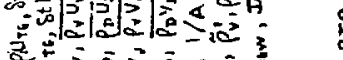

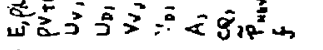
붑 음ำำำㅇ 형

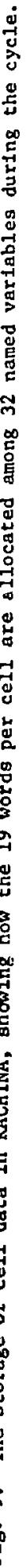


relerenced variables, the new $(n+1)$ values could be stored in completely separate arrays and later transferred, just as $\rho_{v}^{\prime}$ and $\rho_{v l}^{\prime}$ are handled. We have chosen, instead, to temporarily store aside $\bar{I}-$ length vectors of the $(n+1)$ values, transferring them at the end of each row to relieve the demands on cell. storake.

It a'pears that using fewer than 19 words per cell would complicate the computer logic significant$1 y$ while providing very little gain, and using more than 19 would begin to waste space. Our various storage treatments have been governed by a balance between these considerations.

The sontour quantity ( $\mathrm{CQ}$; in the control region demotes the field of some chosen cell variable for which a contour plot is drawn on microfilm. The present ifwices are all of the quantities in words 1 tlitotigh 10, which are automatically plotted in sequence by placing the complete field of each quantity in Co as its plotting turn occurs. This transfer to co could be avoided by simple indexing through words 1 to 10 , but intermediate storage in CQ allows values in bu sujusted specifically for piotting purposes, as is sinctines necessar $y$.

Charts such as Fig. 9 have proven extremely useLul in initidly planning the storage vefore a code i:i witton, but they are equally useful thereafter in virializing the quantities available at any given puint in the calculation cycle, and the locations of scwhage vacancies. The storage layout changes frequenely durins the development of the code, and the version in Fig. 9 is certainly not final for kACHINA.

Reduling the number of storage words per cell, as disiussed above, will help to allow larger meshes to it in SCM, but eventually SCM space is exhausted. The next step is to transfer all the cell data to liarge Curc Memory (LCM), reading only some part of the mish at a time inco an SCM buffer for processing, and then rewriting it back out to LCM. The optimum procedure is shat which requ'res the minimum number of read/write references to LCM, and one could, indeed, tailor the logic for each problem to do this. The procedure we have chosen, however, simply deals with three j-rows of cells at a time in SCM processing, without regard to overall mesh dimensions. To facilitate inclusion of the LCM routine described in Appendix $C$, the cell variables are stored "interleaved" with all the variables for a given ceil stored contiguously, followed by all the variables for the next cell, etc. (Contrast this with the other method of storing cell variaules in individual $\overline{\mathrm{I}}$ by $\overline{\mathrm{J}}$ blocks for each variable. That scheme is competitive only when the computing code is designed for smaller meshes that will always fit in SCM.)

In the SCM version: of this report, the storage block AASC contains all cell. data. At present, it has a dimension of 26676 words, allowing any combination of 1 P 2 by JP2 $\leqslant 1404$ cells, at 19 words per cell. A 25 by 50 logical mesh, requiring an actual 27 by 52 mesh, dictated this particular choice. With the transfer of cell data to LCM, however, it is no longer appropriate to retain AASC within the main SCM common KSC, because KSC should contain only the tape restart information. Therefore, AASC is defined in a separate SCM common that is never written on tape, and the tape $\mathrm{d}_{\mathrm{m}} \mathrm{mp} /$ restart routines are modified to write/read the entire LCM storage block of complete cell. data. These and related matters are discussed in detail in Appendix $C$.

Next, we must consider how the code actually accesses cell data.

The single-subscript index notation described in Sec. $I i . B$ can remain the same, whether the cell data are stored in SCM or LCM, because the actual location of the data is transparent to the primary overlays. Subroutine LOOP in the $(0,0)$ overlay is of crucial importance here, as it has complete control over all references to cell data and relieves the primary overlays of any direct , ncern with cell data transfers.

In essence, LOOP's responsibility is simply to have three rows of the mesh. $j, j+1$, and $j-1$, available in SCM for processing, and to have the corresponding indices IJ, IJP, ind IJM set properly to the column $i=2$ cells to begin the processing of each row. At the end of each row, LOOP must step up the one row in $j$ and reset the tiree indices accordingly.

In the SCM version of the program, this process is trivial because no LCM logic is involved. Sweeps over the mesh always begin at the lower, left corner and move across to the right edge, then up by rows of cells. To begin a typical sweep, the calling program CALLS the "START" entry in LOOP, which merely sets IJ to reference the lower left cell $(2,2)$, 
IJP to reference the cell $(2,3)$ above it, and IJM to reference the cell $(2,1)$ below. Control is then RETURNed to the calling program, which then initiates an ordinary doubie do loop.

Secondary indices are often needed to reference cells located in columns to the left or right of the column identified by I.J, IJP, and IJM. These indices are easily obtained by applying increments or decrements of the variable NQ, the number-oi-quantitics, that is, the number-of-storage-words-per-cell, to the three frimary indices. In this manner, reference can be made to any neighbor of eull IJ shown in Fig. 7.

Similarly, the calling program can progress across the row from left to right by adding NQ to each index, to advance one column at a time. At the end of the row, the I Do loop falls through, leaving $I J, I J P$, and IJM referring to cells in column IPI. A CALL is then issued to the "LOOP" entry point in LOOP, which increments the three indices over two additional columns by adding ( $2 \star_{\mathrm{NQ}}$ ) to each index. This actually sets the indices back to the left and up through column 1 of the next row, stopping at column 2. Control is again RETURNed to the calling program, and this process is repeated until the entire mesh has been swept, as indicated by the fact that the outer Do loop on $\mathrm{J}$ falls through.

The number of storage words per cell in this KACHINA version is seen to be $\mathrm{NQ}=19$, as per Fig. 9. This number may be increased very simply by adding the new variables to the EQUTVALENCE and DIMENSION statements in the Comdecks EQVREAL and DIMEN, and redefining NQ in the $(0,0)$ main progran at one place only.

\section{An Optional Three-Row Buffering Scheme}

When placing all the cell data in LCM, the most significant modification to the code logic is to replace subroutine LOOP by an expanded version that will shuttle the cell data between the large LCM array and the small SCM buffer where it is operated on. These changes are detailed in Appendix C. Generally, LOOP will keep three complete rows of the mesh in SCM at any one time: the row being processed and the rows above and below, again referred to by IJ, IJP, and IJM. All calculations affecting cell data are actually performed directly on the current contents of the buffer. The merit of interleaving the cell data now becomes evident, as all quantities pertain- ing to the three rows of cells are instantly avaijable. The schematic flow diagram and sample FORTRAN Do loop in Fig. 10 enlarge on the previous discussion to show how buffering can be added.

( 1$)$ is in the SCM version, the "START" entry of LOOP is CALled before the double DO loops are initiated. But now, START reads in the entire contents of the bottommost three rows of the mesh from LCM to the SCM buffer, placing row $j=1$ in the buffer section designated "row $1 / 3 ;$ " likewise, row $j=2$ is read into "row $2 / 3$," and row $j=3$ is read into "row 3/3." Rows $1 / 3,2 / 3$, and $3 / 3$ are contiguous in $\mathrm{SCM}$, and like their counterparts in LCM, each contains $N Q 1=N Q * I P 2$ words. With the three rows read $1 n$, the caliing program needs to know how to access data in the buffer. As before, this information is provided by setting I.JM, IJ, and IJP to point to the first words of the $i=2$ column of cells in each row. Thus, IJM points to an address NQ words into SCM row $1 / 3$, as do $I J$ in row $2 / 3$ and IJP in row $3 / 3$. Note the indicator IBUF, which is set to 1 ; it will control the subsequent reading and writing of individual rows and the resetting of the three indices. With the fjrst three rows of cells read in and the basic indices set, control can be RETURNed to the calling program.

(2) The double to loops are initiated, and processing is performed exactly as previously described for the SCM version. In the example shown in Fig. 10, we calculate the average $u_{v}$ and $v_{v}$ at the center of cell $(i, j)$. The terminai statentent of the inner DO loop, which again counts columns within each row, is statement Nu. 89. Note how the primary indices IJ and IJM are advanced to the next column in the row. The inner loop on $I$ is repeated until the row is completed, at which time control passes to the "CALL L $\emptyset \emptyset \mathrm{P} "$ statement.

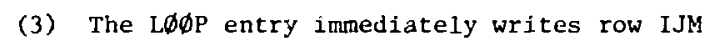
back into LCM, and, depending on the value of IBUF, goes to statement No. 10, 20, or 30. Because IBUF was initially set to 1 , control fasses to statement No. 10 in our example. Note that now the indices $I J P, I J$, and IJM are reset to point to different SCM rows -- IJP to the vacated row $1 / 3$, IJ to $\mathrm{J} / 3$, and IJM to $2 / 3$. IBUF is reset to 2 to control the next entry to LOOP, and control passes to statement No. 40 which will read the new IJP row, row $j=4$, into 
《ENTRY LOOP》

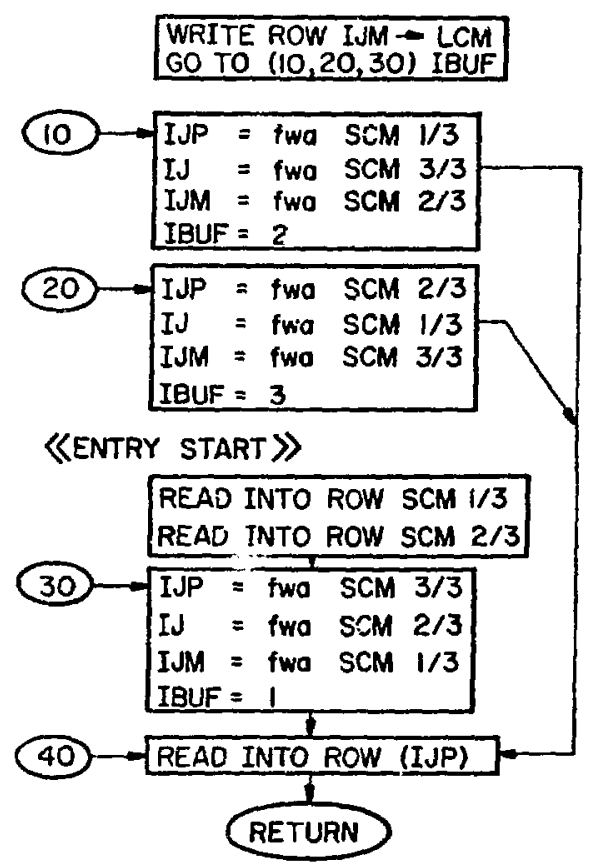

《ENTRY DONE》

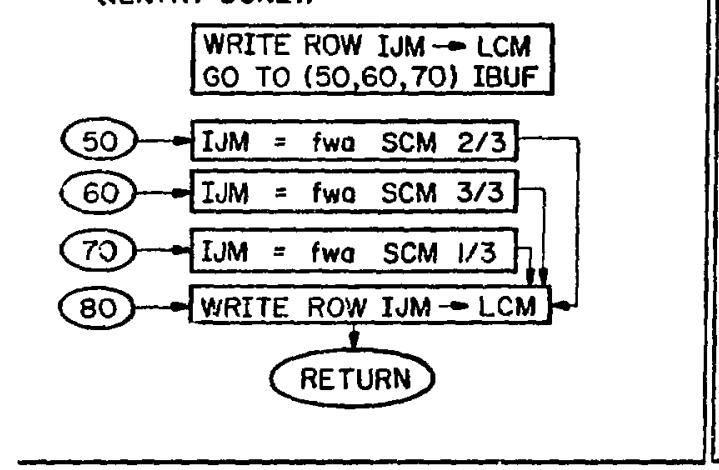

SCM BUFFER

Row $3 / 3$

ROW 2/3

ROW $1 / 3$

INTERLEAVED STORAGE af NQ WDS/CELL

LOOP EXAMPLE:

\begin{tabular}{l|l} 
CALL START \\
DO $99 \quad J=2, J P 1$ \\
DO 89 I $=2, I P I$ \\
IMJ $=I J-N O$ \\
UIJ $=0.5 *(U V(I J)+U V(I M J) \|$ \\
VIJ $=0.5 *(V V(I J)+V V(I J M))$ \\
IJ $=I J+N O$ \\
99 \\
99
\end{tabular}

\begin{tabular}{|c|c|c|c|c|c|c|c|c|c|c|c|c|c|c|}
\hline ROW $3 / 3$ & $\rightarrow$ (IJP) & $\begin{array}{l}J \\
3\end{array}$ & (IJ) & $\begin{array}{l}J \\
3\end{array}$ & (IJM) & $\begin{array}{l}J \\
3\end{array}$ & (IJP) & $\begin{array}{l}J \\
\sigma\end{array}$ & (IJ) & 6 & (IJM) & $\begin{array}{l}J \\
\sigma\end{array}$ & (IJP) & $\begin{array}{l}J \\
g\end{array}$ \\
\hline ROW $2 / 3$ & $\rightarrow(I J)$ & 2 & (IJM) & 2 & (IJP) & 5 & (IJ) & 5 & (IJM) & 5 & (IJP) & 8 & (IP) & 8 \\
\hline ROW $1 / 3$ & (IUM) & 1 & (IJP) & 4 & (IJ) & 4 & (IJM) & 4 & (IJP) & 7 & (IJ) & 7 & (IJM) & 7 \\
\hline
\end{tabular}

Fig. 10. KACHINA three-row buffer. 
SCM row 1/3. Observe that there has been no unnecessary shuffling of data in SCM: row $j^{-1}$ was read out and replaced by row $j+1$, and the three indices were reset to point to the locations of rows $j+1, j$, and j-1. As shown at the bottom of Fig. 10, the grid rows in SCM are in their actual logical order only every third row.

(4) LOOP returns to the calling program, advancing the outer D0-loop index $\mathrm{J}$, and rows are processed similarly until all those specified by index $J$ have been processed. Then control passes to the "CALL DONE" statement, an entry point that simply RETURNed in the SCM version.

(5) DONE is really only a cleaning-up operation. Because no further LCM reads are required, it merely writes the final two rows, $j$ and $j+1$ (JPI and JP2, respectively) back out into LCM. CALL DONE can be omitted on those loops, such as certain output routines, that reference but do not alter cell data.

Not indicated in the flow of Fig. 10 is the incrementing of the relative address indices for reading and writing LCM. These indices are initially set to 0 and incremented by NQI as processing progresses up the mesh.

Complete information on converting KACHINA to an LCM version with the three-row buffer routine is provided in Appendix $\mathrm{C}$, which lists the changes required to convert the basic SCM version of KACHINA provided in Appendixes $\mathrm{A}$ and $\mathrm{B}$.

The SCM version has been built so that the $(1,0)$ and $(2,0)$ overlays are completely compatille with LCM usage and require no modification in the conversion.

Recall that the SCM buffer AASC becomes separated from the SCM common block KSC. A dimension of oniy 581410 words $(=3$ rows * 19 words per cell * 102 columns) will allow any $\bar{I} \leqslant 100$. Considering the reduction from the present 26676 words, and also the great capacity of LCM (on the order of $400 \mathrm{~K}_{10}$ words are available), it becomes evident that very large problems can be run with the LCM version of KACHINA. Further, the goal of freeing a considerable amount of SCM space is achieved.

\section{E. Marker Particles}

Marker particles are a purely optional feature in KACHINA, as they do not influence the flow, but are simply carried along with it. Microfilm plots of particle coordinates are often a very useful form of visual output, as they not only distinguish readily the regions occupied by the various components, but also indicate relative proportions of the interpenetrating components within each region. Marker particle plots also aid in the location of shock fronts, rarefaction waves, and reglons that have become incompressible. These benefits become especially evident when motion pictures are generated by drawing a plot each calculation cycle. For these reasons, marker particles are a valuable part of most KACHINA studies.

Although the markers are moved by fluid velocities in the usual fatsion, which will be described at ihe end of this sercion, the concept of our multifield KACHINA model introduces some novel aspects of marker creation.

First, it is appropriate to have a separate set of particles for each field component. This is necessary to allow accurate particle movement in our interpenetrating fluid model and to provide the proper visual distinction between the fields and their components. Each particle is tagged to indicate the component with which it is associated. This tag not only specifies whether the particle is to be moved according to $u_{v}$ and $v_{v}$ velocities or $u_{d}$ and $v_{d}$ velocities, but also indicates the plotting symbol chosen to Identify the component.

The second novel aspect is the initial particle distribution. In the typical fluid-dynamics computer code, the density and spacing of particles is determined by specifying the tutal number of particles per cell in each direction, but in KACHINA we specify the total number of particles per unit area, called NPUA, expressed in cell units. In combination with the initial void fraction and the densities in each particular area, NPUA is subdivided inco appropriate parts to determine the effective nuaber of particles per unit area (PNEFF) for each type of particle. Therefore, a region with a large void fraction will contain a higher ratio of vapor particles to droplet particles than will a region with a smaller void fraction. The larger $\theta$ is, the smaller the number of jroplet particles dispersed over the region, and at the limit $\theta=1$, no droplet particles at all will be generated. The situation reverses as $\theta \rightarrow 0$, and at $\theta=0$, no vapor particles are generated. 


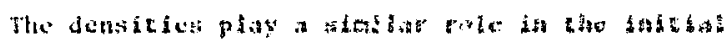

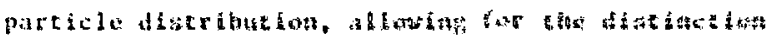

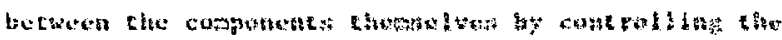

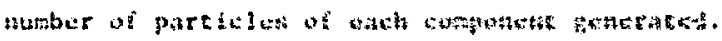

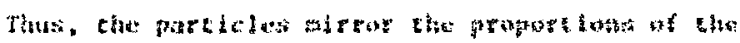

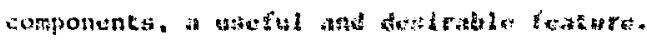

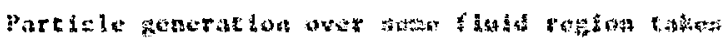

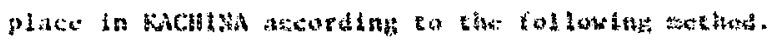

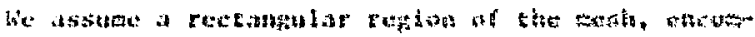

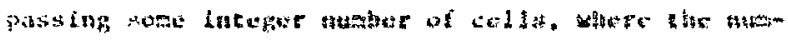

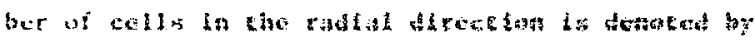

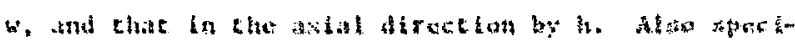

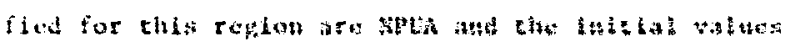

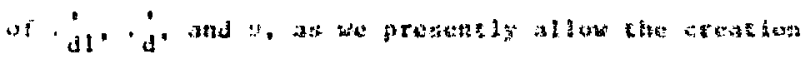

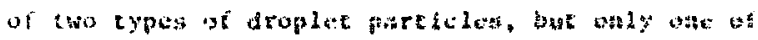

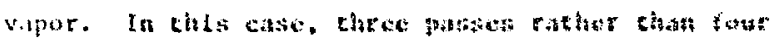

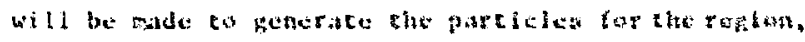

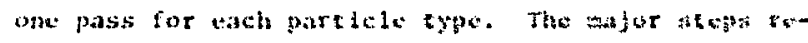

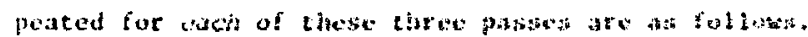

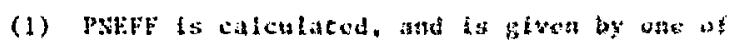

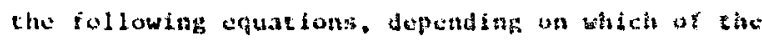
chrec passes is being pertormed.

(a) For droplet conposent nusber 1.

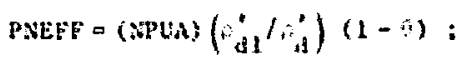

(b) For droplet component number 2,

$$
\text { DNEFF }=(\text { NPUA })\left|1-\left(n_{d 1}^{\prime} / d\right)\right|(1-d) \text {; }
$$

(c) For the vapor, PAEF = (NPUA) 0 .

(2) A uniform matrix of parteles is so be lafe down over the region, the cocal number to be given by tine product of XNP particles in the $r$ direction times YNP particles in the $z$ direction. By this definition,

$\frac{X N P}{Y N P} \equiv \frac{\omega}{h}$,

and

$(X N P)($ YNP $) \equiv W h(P N E F F)$

These equations are comblned and solved for XNP and then YNP:

$X N P=w(P N E F F)^{\frac{1}{2}}$, $\mathrm{YNP}=(\mathrm{XNP}) \mathrm{h} / \mathrm{w}$,

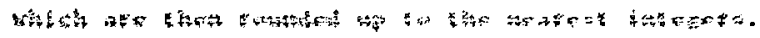

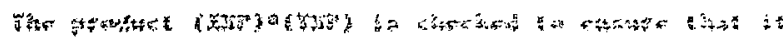

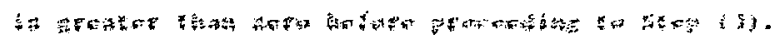

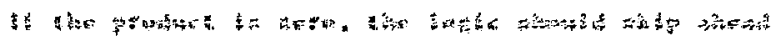

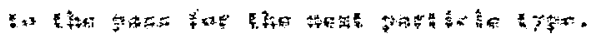

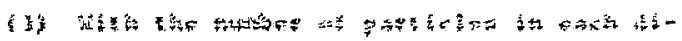

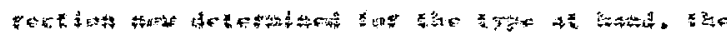

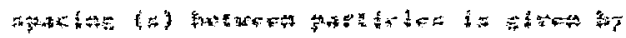

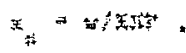

$\rightarrow 424$

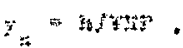

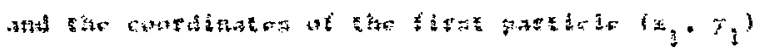

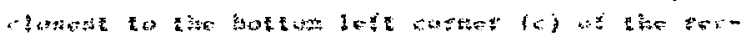

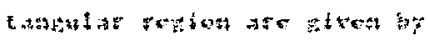

$x_{1}=\frac{x_{c}}{2}$.

-

$y+x+\frac{3}{3}$.

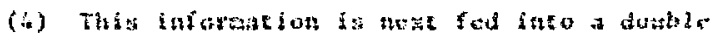

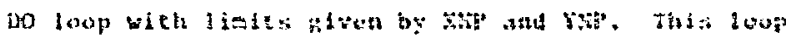
generates and stores thas array of particlete ast ap-

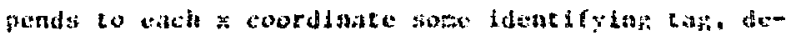
pendling on tine fumber of che prasts.

If destred. Che variable "dppset" ay be changed from ics usual 0.0 co 1.0 to unformly displace thic entire parcicle matrix to the upper rlahe by a disitance $x_{s} / 4$ and $y_{s} / 4$. For the use of DFFSET, refer so che description of a "part card" In Sec. 11.8.

$A$ sec of chrec such passes is perforesed for each discrete fluid region in the mesh, each pass contributing some number of particles, which are accumulated into the total collection.

an example of the above schemc, with actual numbers and complece with drawings and cbart, is given on the page laveled 4 in the Flow Diagran in Appendix A, where che complete ilow for Marker Parclele Generation also appears in detail. 


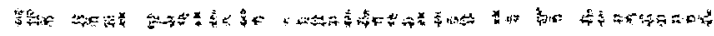

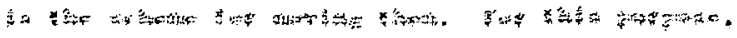

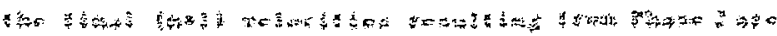

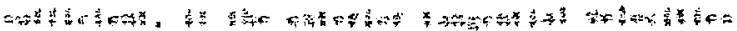

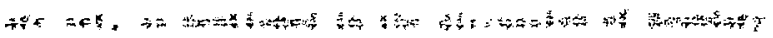

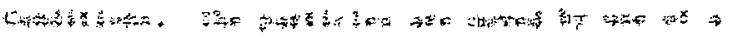

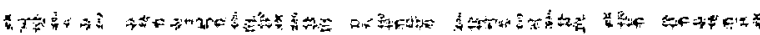

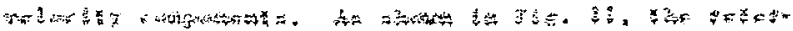

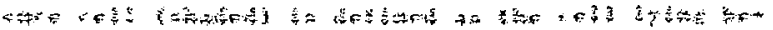

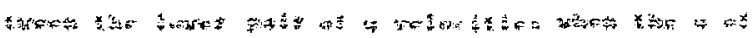

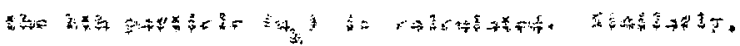

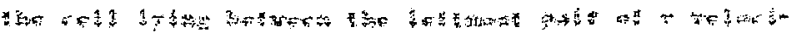

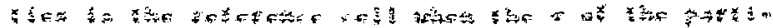

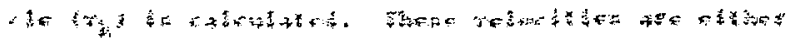

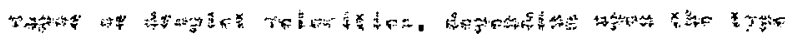

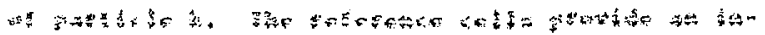

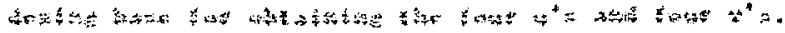

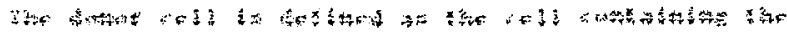

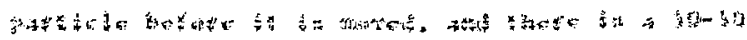

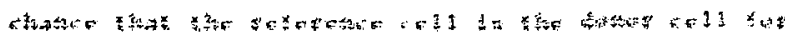

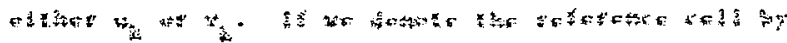

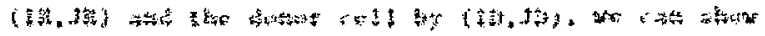

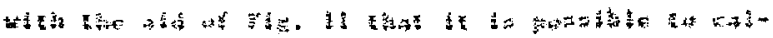

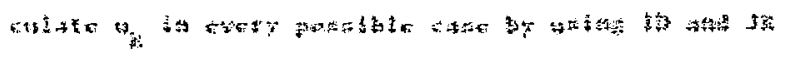

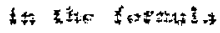

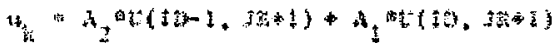

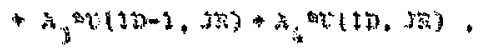

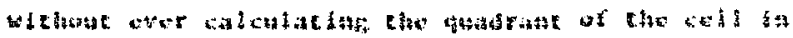

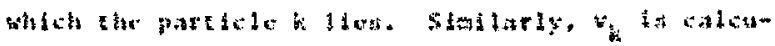

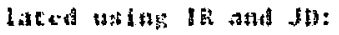

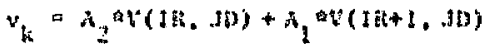

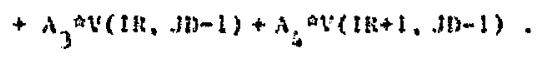

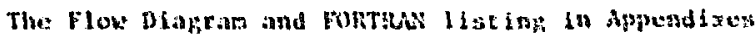

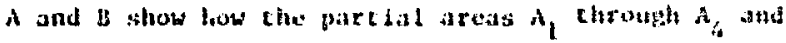
the sinfle subser lpt equivaleats co IR, IR, ID, isthe JD are obtalned qufekly without ever test ing the parcfele's pusition. Alter $k_{k}$ and $v_{k}$ have been datermined, tho particles are nuved according to

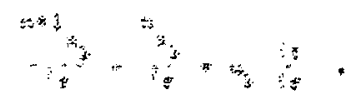

$2 \pi$ sives

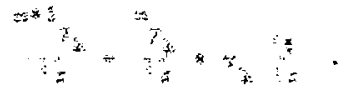

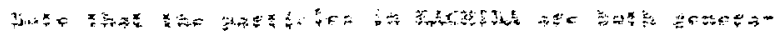

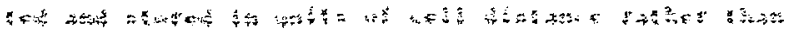

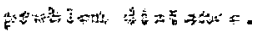

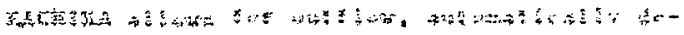

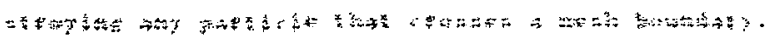

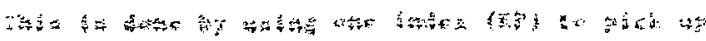

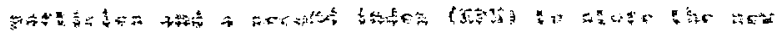

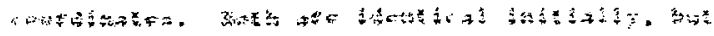

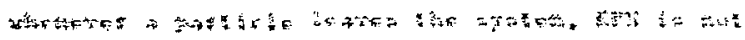

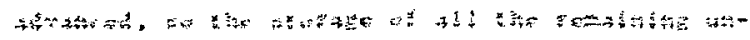

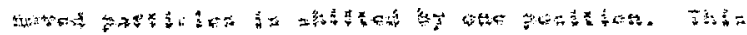

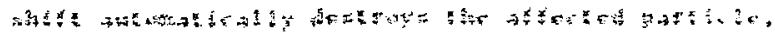

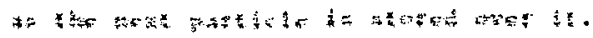

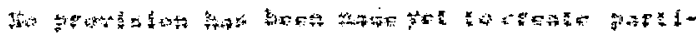

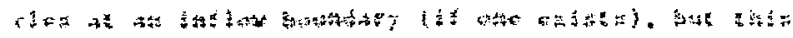

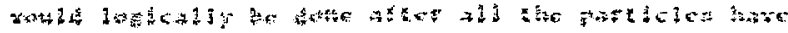

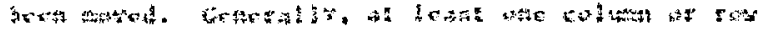
ज施

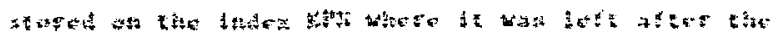

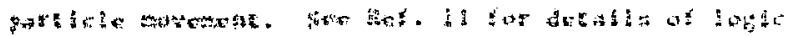

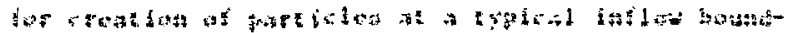
WF".

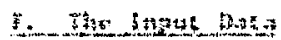

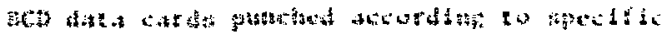

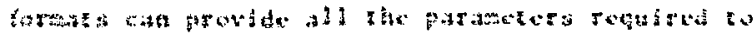

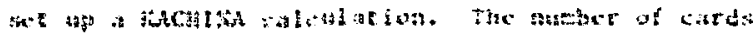

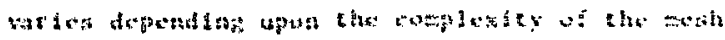

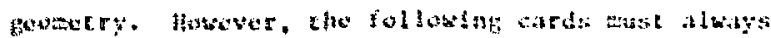
atpestit.

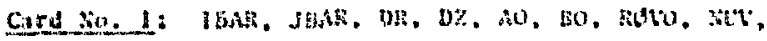
Cok, shath (Eorait 214, \$Fs.1), where:

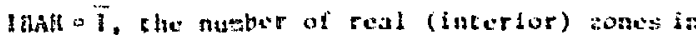

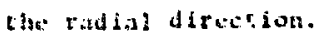

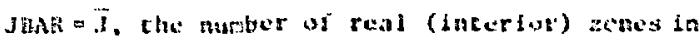
the axial direction.

Dotr, the cell size in the radial directon. Dy $3 z$, the coll siat in the axial direction. 
(a)
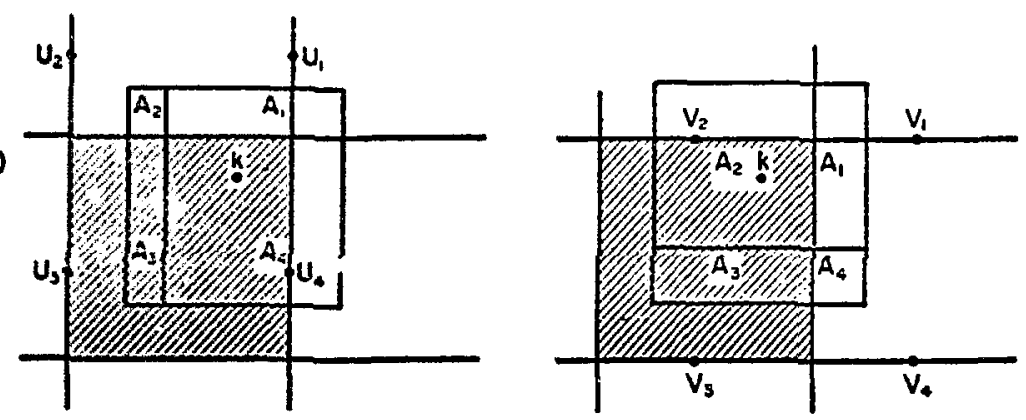

(b)
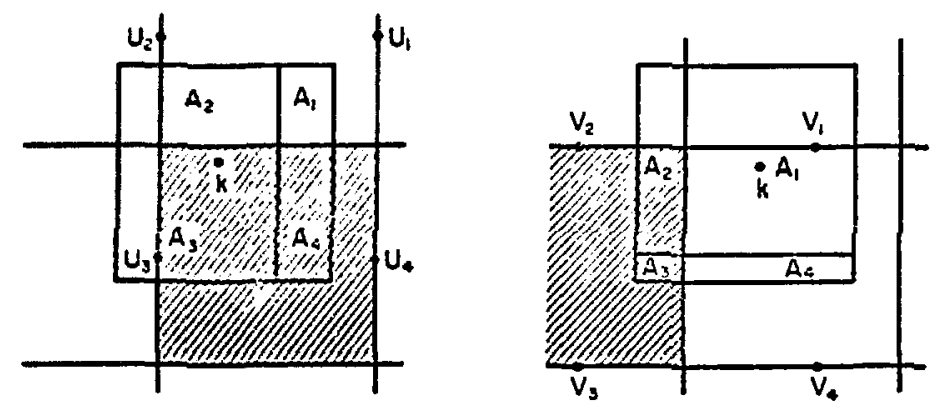

(e)
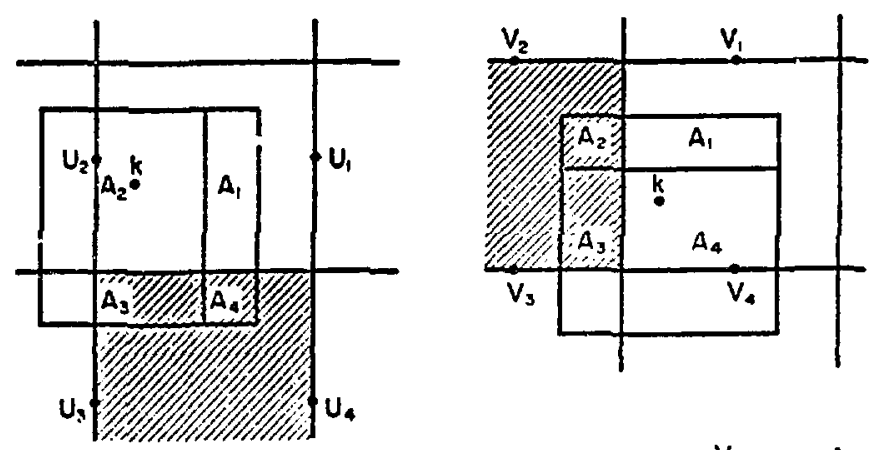

(d)
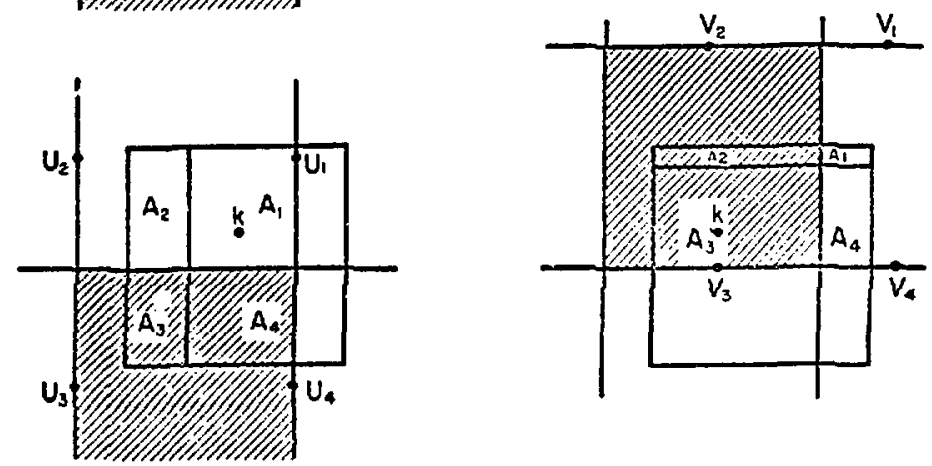

F1g. 11. Area velocity welght1ng scheme for $u_{k}$ and $v_{k}$, with particle $k$ shown for each of the four quadrants of the ce11. The reference cell is shaded in each case. The subscripted $u$ and $v$ veloctites are those of elther vapor or droplets, depending upon the type of particle $k$. 


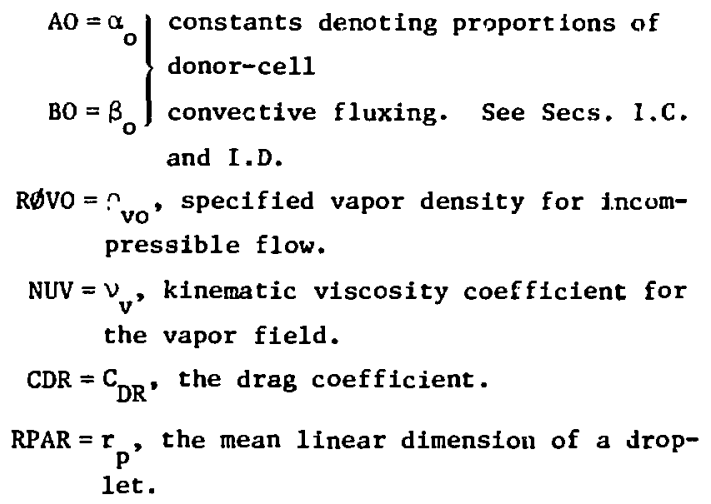

Card No. 2: NAME (Format 8A10), where columns 2-80 are used for problem identification on prints and all film frames.

Card No. 3: IDCOMP (Format 8A10), there columns 2-80 are used to identify material components once at the beginning of the film and printer output. ( $0 \mathrm{n}$ both these cards, column 1 is treated as a carriage control, so it should be left blank. Iî desired, both cards may be left entirely biank, but they must always appear in the input deck.)

Card No. 4: GMP, ØMRø, EPS, G, KV, KD, EPV, EPD, R

(Format 9F8.3), where:

$\emptyset \mathrm{MR} \emptyset=\omega_{\rho}=\begin{aligned} & \text { Phase-2 iteration relaxation para- } \\ & \text { meters. } \\ & \text { See Sec. I.D for description. }\end{aligned}$

EPS $=\varepsilon_{1}$, the convergence criterion for both iterative solutions in Phase 2. (With reference to Sec. I.D, only $\varepsilon_{1}$ appeais in the input, whereas $\varepsilon_{2}$ is specified directly in the coding.)

$G=g$, gravity felt by both vapor and droplets, acting only in the axial direction, which may be + or - to pull up or down, respectively.

$\mathrm{kV}=\mathrm{k}_{\mathrm{v}}\left\{\begin{array}{l}\text { Heat conduction coefficients for the } \\ \mathrm{kD}=\mathrm{k}_{\mathrm{d}}\end{array}\right\}$

$E P V=\varepsilon_{v} \mid$ Epsilons for the Phase-1 nonisotropic

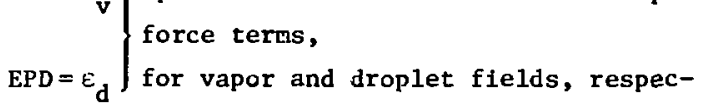
tively.

$R=R$, the exchange function that describes heat transfer between vapor and droplet fields.
Card No. 5: Rø1, Rø2, CNML, GAM2, BVi, BV2, BD1, BD2 (Format 8F8.3), where:

$$
R \emptyset 1=\rho_{1} \mid \begin{aligned}
& \text { The actual microscopic material } \\
& \text { densities of the two droplet } \\
& \text { components. }
\end{aligned}
$$
GAM1 $=\gamma_{1}$, The ratio of specific heats for the two vapor components,
GAM2 $=\gamma_{2}$ appearing in Phase-1 th equation and pressure calculation.

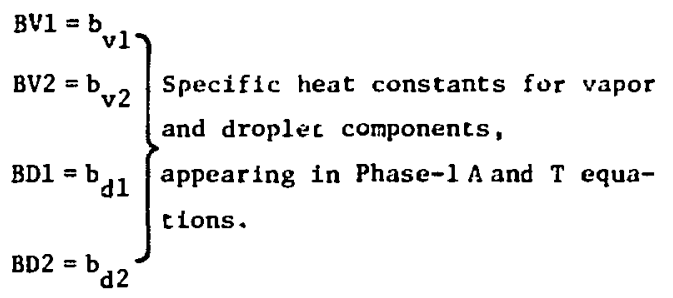

Card No. 6: JRIGID, IB 6 T, THIN, R SIEVIN, VVIN, ITOP (Format 2I4, 5F8.3, I4), where: JRIGID = the incegral number of cells up the right boundary that are to be treated as rigid free-slip. Any cells above JRIGID are treated as continuative outflow. $0 \leqslant J R I G I D \leqslant J B A R$, See Sec. I.E.

$I B \emptyset T=$ Boundary condition for the (entire) bottom boundary, $=0$ for rigid free-slip, $=1$ for continuative outflow, $=2$ for specified inflow, where:

$$
\begin{aligned}
& \text { THIN }=\theta_{\text {in }} \quad \begin{array}{l}
\text { Parameters for specified inflow } \\
\text { along bottom boundary when }
\end{array} \\
& \text { RøVIN1 }=\left(\rho_{v 1}\right)_{\text {in }}\left\{\begin{array}{l}
I B \emptyset T=2 ; \theta_{i n},\left(\rho_{v 1}\right)_{i n},\left(\rho_{v 2}\right)_{\text {in }}, \\
\text { and }\left(I_{v}\right)_{\text {in }} \text { refer to the }
\end{array}\right.
\end{aligned}
$$

IT P Boundary condition for the (entire) top boundary, $0=$ rigid free-slip, $1=$ continuative outflow.

Card No. 7: T, DT, T2OMD, TLIMD, TWFIN, LPR, ISPR, (CøLøUR $(N), N=1,3$ ) (Format 5F8.3, 2J4, 3F4.1), where: $T=t_{0}$, the problem starting time, usually zero.

$D T=\delta t_{0}$, the initial $\delta t$. Except in movie runs, $\delta t$ is chosen automatically after cycle 10, according to the condition $\delta t=0.1 \min \left(\delta r / u_{\max }, \delta z / v_{\max }\right)$, where 


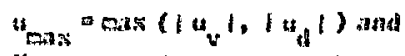

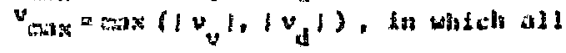
volowitics ower tho math aro constderat.

T2030 $=1.0$ to forec cape dubps every $20 \mathrm{ma}$ ar coneral prucobsor (CP) tefer for restareing, or a 0,0 to bypass elass opelor.

TLIMD $=1.0$ to force a cape dofap and agrugh ro the $(0,0)$ overlay Just bege che ef the late spectifed on che Jats card is reached;

$>1.0$ to force tape dump and AETUAS LFo-

diacely after sycle 0 auput: $\approx 0.0$ to rum out to a full the late wich no tafoe dump.

THFIN = problen flaish the, when this cimb ( $c$ TWFiN) is reached, control returas to tire $(0,0)$ overlay, (upon RETUR, to $(0,0)$ for either the TLIAD or TWFIN condition, che $(0,0)$ maln program KaCHINA searches the input queue for further tasks.)

LPR = "Long Print" Control, where:

0 a movie option, $1=$ cell-data listing on microf $11 \mathrm{~m}$ only, 2 a cell-dita listing on both $\mathrm{f} 1 \mathrm{~lm}$ and printer, $3=$ cel1-daca listing on printer only. These options are described more fully in Sec. II.G.

ISPR = "Short Print" Control, where: the four-line listing of sumations of mass, momentum, and energy is provided each cycle if ISPR $=2$, or on 1 ; on those cycies that lave the "long print" of cell data if $I S P R=1$.

CQLGUR(N), $N=1,3$ These parameters are effectIve only for color microfilm processing, and are Intentad for movies of particles, where CoLdUR(:) refers to droplet component No. 1, CoLGUR(2) refers to droplet component No. 2, and COLOUR(3) refers to vapor. Seven basic color cholces are available: $0.0=$ white, $1.0=\operatorname{red}, 1.6=$ yellow, $2.0=$ green, $2.6=$ cyan, $3.0=$ blue, and $3.6=$ magenta.

Card No. 8: (DT $(N), N=1,10)$ is used in conjunction with

Card No. 9: $(\operatorname{DT} \emptyset C(N), N=1,10)$ (both are Format 10F8.3), where DT $\phi_{n}$ specifies the problem time output interval for both plots and prints. DTDC $\mathrm{n}_{\mathrm{n}}$ spec1fles the time at which the change to DT ${ }_{n+1}$, As an example, assume that $t$ is in seconds, and that output is wanted every $1 / 4 \mathrm{~s}$ for the first second, then

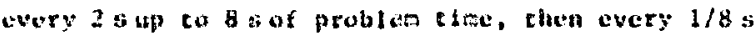
up toc 10, then eore finfequently agato, with output oaly every 10 ancil t 9200 . One tould tist

$$
\begin{aligned}
& \operatorname{sto}(1-10)=0.25,2.0,0.125,10.0 . \\
& \operatorname{drtce}(1-10)=1.0,8.0,10.0,200.0 .
\end{aligned}
$$

To beep the output the lneerval fixed elroughiout a

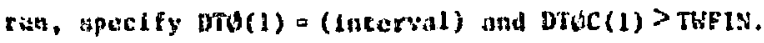
then wi output ine ls belmp spproached, the autoant is de routine (sice at on Card to. 7) w111 choose a spestik be for wa cycle so that the output occurs at the proclise the desired.

The above nine carcis persali to all Nachika setups. They trave defined a nesh and provided the parameters for ifs use. What remains to be defined is the conrencs of thls mesh-- fiuld regions is fill it in, and assocsated marker particles if desired. One "part card" is used to define each fluid region and any assoclated particles. Hecause the number of fluid regions can vary with problen geonetry, the number of part cards also varies accordingly. The present definicion of a "part" is limiced to a cylindrical annulus, encompassing some rectangular region of cells, and constrained to follow cell boundartes. As shown in Fig. 12, four dimensions are adequate to define each part. A part card concalns the following information:

NB, NR, NT, NL, RøDPRI1, RøDPRI2, RGV1, RøV2, SIEVT, SIEDI, NPUA (Format 4I4, 6F8.3, I4), where: NB are four dimensions (see Fig. 12), NR specified in integer numbers of cells to NT emphasize that the part is constrained

ML to follow cell boundaries. Thus, NL and NB specify how many cells in from the left and up from the bottom to locate

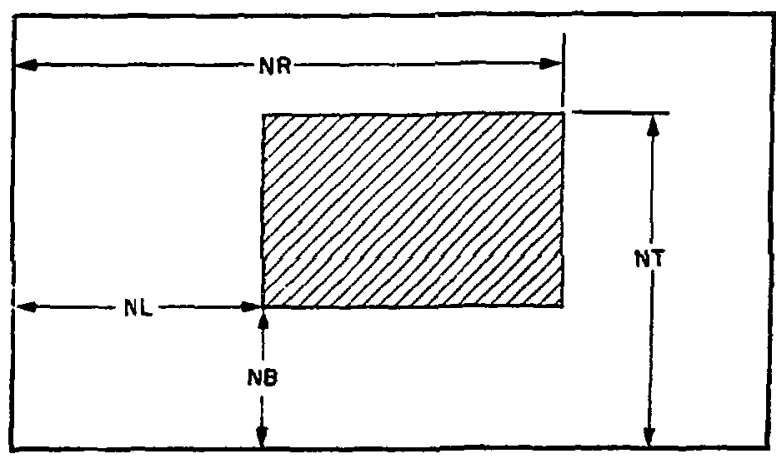

Fig. 12. Part shape available for fluid reglons in KACHINA, defined by the Integral number of cells over and up to the two corners. 
the lower left cozner of the region, and NR and NT similarly locate the upper right corner. As an eximple, if a single region is to cover the entire mesh, sat $N L=N B=0$, $N R=\overline{\mathbf{I}}$, and $N T=\bar{J}$.

\begin{tabular}{|c|c|c|}
\hline DDPRI & $\begin{array}{l}=\left(\theta_{\mathrm{d}} 2\right. \\
=\theta^{2} 1\end{array}$ & $\begin{array}{l}\text { necessary to completely specify } \\
\text { all cells in the fluid region, } \\
\text { described in Sec. I.B. (All } \\
\text { velocities are lnitially set to } \\
\text { aero.) }\end{array}$ \\
\hline
\end{tabular}

NPUA = number of particles per unt area, as described in Sec. II.L. Typical NPUA values In our test calculations have ranged from 1 to 4. To bypass the particle option, slmply set NPUA $=0$ for any or all parts. (Recall also the variable GFFET appearIng in the particle generator, which may be used to displace the particle arrays to the upper right. See Sec. II.E.)

The part cards are processed Individually, and the number of fluid regions is unlimited, clear up to the extreme of one region for each cell. If different parts refer to the same zone or zones, the latest information wfll override any earlier specifications for the cells, but any particles that have been created will be retained, suggesting one possible use for the GFSET parameter.

The set of part cards terminates with the final card having NR $=0$ and the rest of the card unused. Therefore, at least two part cards must appear in a KACHINA input deck.

This completes the discussion of the input data cards. We see that an input deck must consist of at least 11 cards, but the maximum number is unlimited. The final card normally placed at the end of the input deck is in reality the first card for the next problem. The first quantity on Card No. I is IBAR, and it determines the action to be taken by KACHINA. If $I B A R>0$, it is valid for use as $\bar{I}$, and the setup is called. The value $I B A R=0$ indicates a tape restart, and $I B A R<0$ indicates that the end of data has been reached. Thus, a negative IBAR $c$ rd is the appropriate way to terminate a deck, and hence, the job.

G. Output - Plots, Prints, and Motion Plctures

The KACHINA output is in the usual two forms, visual information on $35-\mathrm{mm}$ microfilm or $16-\mathrm{mm}$ motlon-picture film and printed information on microfilm or fanfold paper. Both torms are provided automatically in cycles 0 and 1 , and thereafter at intervals specifled by DT and DTGC in the input data. The microfilm plots are generally the most immediately useful output, and they are made on the II FR-80 or the s-c 4020 computer output microf $12 \mathrm{~m}$ devices. As many as 16 plots are provided in the basic package, fcur particle plots, velocity vector plots of both fields, and contour plots of $\bar{s}$, $a_{d}, a_{v}, z_{d}, I_{v}, I_{d}, p, k$, and $E$.

The particle plots are made by plotting the $x$ and $y$ coordinates at all particles, and they are provided automacically when particles are used. of the four different particle plots, the first is a composite plot of all particles in which a different plotting symbol or color is used for each type of particle. This is followed by a set of three. incividual particle plots, for each of which KACHINA sorts through the particles and plots only those tagged to correspond to the currently specified type. Whereas particle plots are useful in following the motions of the comporsnts of each field, they cannot convey complete information on the flow details. Velocity vectar plots are useful because they show at a glance both the direction of flow and the relative magnitude of the velocities. They are provided separately for both the vapor and droplet fields. Vectors are plotted as if originating at each cell center, deroted by a "+," and their length and direction are proportional to the velocity components. If $\left(x_{1}, y_{1}\right)$ are the coordinates of the center of cell $(i, j)$, the coordinates of the vector end points $\left(x_{2}, y_{2}\right)$ are given by

$x_{2}=x_{1}+\left(\frac{u_{i+\frac{1}{2}}^{j}+u_{i-1 / 2}^{j}}{2}\right)$ DRøU ,

and

$y_{2}=y_{1}+\left(\frac{v_{i}^{j+l_{2}}+v_{i}^{j-\frac{1}{2}}}{2}\right) \operatorname{DR\emptyset U}$,

where $u$ and $v$ refer either to $\left(u_{v}\right.$ and $\left.v_{v}\right)$ or $\left(u_{d}\right.$ and $v_{d}$ ), and DR $\emptyset U$ is a scaling coefficient defined as 
$D R d U=0.9 \delta$ r $\left(V E L_{\max }\right)$

This coefficient is recalculated for pich individual velocity-vector plot, and it scales the length of a vector drawn for the largest $|u|$ or $|v|$ velocity in the system at that instant, $V E L_{\max }$, to be 9/10ths of the radial call dimension ôr. This method ensures that the vectors are always of reasonable length, regardless of velocity magnitudes. The plot is omitted If there are no significant velocities $\left(V E L_{\max }<10^{-10}\right.$ ) in a particular field.

Contour plots are drawn for any cel1-centered quantity stored in CQ, and they are composed of connected vector segments joining points of equal value, fust as the ines on a contour map join polnts of equal elevation. At present, the plots are all linear in contour increment.

In addition to the vartous plots described above, three different types of numerical listed data are provided.

The "long print" is a complete numerical 1istIng of the principal field variables over the entire mesh. Two lines containing the $i$ and $j$ and 16 fleld quantities are given for each cell. They appear as

follows. On the first line:

$i, j, \theta_{i}^{j},\left(u_{v}\right)_{i+\frac{1}{2}}^{j},\left(v_{v}\right)_{i}^{j+\frac{1}{2}},\left(I_{v}\right)_{i}^{j},\left(\rho_{v 1}^{j}\right)_{i}^{j},\left(\rho_{v}^{\prime}\right)_{i}^{j}$, $D_{i}^{j}, p_{1}^{j}$. On the second line: $E_{1}^{j},\left(u_{d}\right)_{i+\frac{1}{2}}^{j},\left(v_{d}\right)_{i}^{j+\frac{1}{2}}$, $\left(I_{d}\right)_{i}^{j},\left(\rho_{d 1}^{\prime}\right)_{i}^{j},\left(\rho_{d}^{j}\right)_{i}^{j}, A_{i}^{j}, K_{i}^{j}$,

The "short print" is a four-line listing of sums over the mesh of mass( $M$ ), momentum (MDM) in the $r$ and $z$ directions, internal energy (IE), kinetic energy (KE), and total energy ( $E$ ). In addition to first specifying the current problem time and cycle number, the 4 lines provide 20 summations in the following order.

\begin{tabular}{|c|c|c|c|c|}
\hline$\sum \theta$ & $\Sigma\left({\mathrm{M} \emptyset \mathrm{M}_{\mathrm{r}}}_{\mathrm{V}+}\right.$ & $\sum\left(M^{\prime} M_{z}\right)_{v}$ & $\Sigma\left(\mathrm{M}_{\mathrm{z}} \mathrm{M}_{\mathrm{z}}\right)_{\mathrm{d}}$ & $\Sigma\left(M_{z}\left(M_{v+d}\right)\right.$ \\
\hline$\sum\left(M_{v}\right)_{1}$ & $\Sigma\left(M_{d}\right)_{1}$ & $\sum \mathrm{IE}_{\mathrm{v}}$ & $\Sigma I E_{\mathrm{d}}$ & $\sum I E_{v+d}$, \\
\hline$\Sigma\left(M_{v}\right)_{2}$ & $\Sigma\left(M_{d}\right)_{2}$ & $\sum \mathrm{KE} \mathrm{v}$ & $\Sigma \mathrm{KE}_{\mathrm{d}}$ & $\sum \mathrm{KE}_{\mathrm{v}+\mathrm{d}}$, \\
\hline$(M)$ & $\Sigma\left(\mathrm{M}_{\mathrm{d}}\right)_{1+2}$ & $\Sigma \mathrm{E}_{\mathrm{v}}$ & $\Sigma \mathrm{E}_{\mathrm{d}}$ & $\sum E_{v+d}$. \\
\hline
\end{tabular}

This short print is provided every cycle $\mathcal{L}_{\tilde{f}}$ the input varfable ISPR $=2$, or only on those cycles that have a long print if ISPR $=1$. LPR, another variable
In the Input data, has primary control of the destination of both the long and shurt prints, where:

$L P R=1$ gives prints on microfilm only,

LPR $=2$ gives prints on microfilm and fanfold paper,

$L P R=3$ gives prints on lanfold paper only.

If $L P R=0$, bcth long and short prints are omitted, and no alphanumerfe writing of any kind appears on microf $11 \mathrm{~m}$. LPR $=0$ is intended for motion picture use, and the only microfilm ottput is the first (complete) particle plot. For movies, KACHINA bypasses the automatic jt that normally would begin af ter cycle 10, and the user must be sure to choose an input $\delta t$ that is at least as small as the minimum St required at any time during the course of the problem, usually determined by a preceding run with normal output, and also to set DT $=\delta t$ and DTOC $\geqslant$ TWFIN. For color orocessing, the chosen colors are specified by Colour $(N), N=1,3$ in the input data, as cescribed in Sec. II.F. The code is easily altered to provide some plot other than this particle plot for the movie or to have a frame shared by seuraral different types of plots.

Finzlly, a one-line print is provided on fantold paper every cycle, regardless of the LPR setting, and also on microfilm if $L P R=1$ or 2. This line contains the following nine quantities.

$\mathrm{T}$ is the current problem time.

CYC is the current cycle number.

DT is the current $\delta \mathrm{t}$.

$\mathrm{CP} \quad$ is the current central processor (CP) clock time.

GRINDS $=\delta C P /(\bar{I} * \bar{J})$, the elapsed $C P$ time for the cycle just completed, divided by the total number of cells. The CP time per ce11 per cycle is a useful indicator of the code's computing efficiency.

ITP is the number of iterations requires for convergence in the preceding Phase-2 pressure iteration.

CELLS is the number of cells that failed to converge in the pressure iteration, and is zero unless the iteration fajled to converge and was cut of $f$ at ITERS $=100$.

ITR CELLS ceding Phase-2 $\widetilde{\rho}_{\mathrm{v} 1}^{\prime}$ iteration. 


\section{Tape Dump and Restart}

Tape cumps are staged out as Fileset 8 in the control region under influence of the quantities T2OND and/or TLIBD, as described in Sec. II.F. The variables dumped are the contents of the SCM common KSC and also the LCM block, if cell data have been transferred to LCM storage, as described in Secs. II.C and II.D and Append IX C.

A tape restart is performed by staging in the dump tape as fileset 7 . The input deck consists of an $I B A R=0$ data card, where JBAR = the dump number on the tape and is used as a check.

\section{The Common Block KSC}

The following list provides the names, descriptions, and sources of all quantities in the SCM COMMD/KSC/ in the $(0,0)$ overlay. This common is of fundamental importance in communication rmong the yarious overlays and their subroutines. By design, it contains all the SCM-based information that must be maintained from cycle to cycle, as it is the SCM portion of the tape-dump data.

The sources in the list are keyed to the following symbols.

$I$ = Supplied as part of the standard input data. The parenthetical symbol that follows I spectifies where this quantity is read,

$0=(0,0)$ Main Progran,

$L=(0,0)$ Subroutine Løø?,

$S=(1,0)$ Subroutine SETUP,

$H=(2,0)$ subroutine HYDR.

Multiple sources Indicate that the quantity is recalculated.

\section{NAME}

AA

AASC

AKINFI

AO

BDT $\emptyset \mathrm{DR}$

BDTøDZ

BD1

BD2

BINF

$\mathrm{B} \emptyset \mathrm{UT}$

BV1

BVIGMII

BV2

BV2rM12

BO

CDR

CøLøUR

C1

DR

DR 12

DRSQ

DT

DT

DT $\varnothing \mathrm{C}$

DTøDR

DTøDZ

$\mathrm{DTO} 2$

DTP $₫ 5$

DZ

\section{DESCRIPTION}

SOURCE

Dummy word, always the first word in the COMMN.

Cell storage, appears in this $C \emptyset M M_{N}$ for SCM version only.

$A_{\infty}, K_{\infty}$ for sudden incompressibility. See Sec. I.F.

$\alpha_{0}$, a constant in the convective fluxing. See Secs. I.C and I.D.

$\beta_{0} \delta t / \delta r$.

I (0)

$\beta_{0} \delta t / \delta z$.

$b_{d 1} \cdot$

$b_{d 2} \cdot$ Specific heat constants for the droplet field.

$=1.0$ if bottom boundary has specified inflow; $=0.0$ otherwise .

$=1.0$ if bottom boundary has continuative outflow; $=0.0$ otherwise.

$b_{v 1}$.

$\left(b_{v 1}\right)\left(Y_{1}-1 \cdot\right) \cdot$

$b \times 2^{\circ}$

$\left(b_{v_{2}}\right)\left(Y_{2}-1 \cdot\right)$.

$\beta_{o}$, a constant in the convective fluxing, used in conjunction with $\alpha_{0}$.

$\mathrm{C}_{\mathrm{DR}}$, drag coefficient appearing in the $\mathrm{K}$ equation.

Colors for movie. See Secs. II.F and II.G.

The $\mathrm{h} / \mathrm{mIn} / \mathrm{s}$ on the wall clock when the job began. Printed with DI.

$\delta r$, the cell size in the radial direction.

$\delta \mathrm{r} / 2$.

$\delta \mathrm{r}^{2}$.

$\mathrm{S}$

$\delta t$, the time step, subject to automatic recalculation.

I (S), H

Problem time interval between outputs (plots and prints).

Problem time at which to change to next DT ir the set.

$\mathrm{S}, \mathrm{H}$

$\delta \boldsymbol{r} / \delta \mathbf{r}$.

$\mathrm{S}, \mathrm{H}$

$\delta t / \delta z$.

$\mathrm{S}, \mathrm{H}$

$\delta t / 2$.

$\mathrm{S}, \mathrm{H}$

$\delta$ t possible for the cycle, but $\delta t$ used may be reduced to adjust to output time.

I (0) 
DZø2 $\delta_{z} / 2$. S

DZSQ $\delta z^{2}$. $\quad S$

DI The month/day/year when the job began. Printed with c1.

EM1O $10^{-10}$.

EM3 $10^{-3}$.

EM6 $10^{-6}$.

EPS $\varepsilon_{1}$, convergence criterion for both Phase-2 iterations. I(S)

EPV $\varepsilon_{v}$ and $\varepsilon_{\mathrm{d}}$, appearing in the $F$ (nonisotropic force) terms. $I(S)$

EP9 $10^{9}$.

EP10 $10^{10}$.

EP20 $10^{20}$.

FIBAR Floating-point equivalent of $\overline{\mathrm{I}}$. $\mathrm{S}$

FIXL Floating-point frame coordinate for left edge of plots. $S$

FIXR Floating-point frame coordinate for right edge of plots. $\quad S$

FIYB Floating-point frame coordinate for bottom edge of plots. $S$

FIYT Floating-point frane coordinate for top edge of plots.

FJBAR Floating-point equivalent of $\overline{\mathrm{J}}$. $\mathrm{S}$

$G \quad g$, gravity felt by both vapor and droplets, \pm . I(S)

GAM1 $\gamma_{1} \cdot \mid$ Ratio of specific heats for $\quad$ I(S)

GAM2 $Y_{2} \cdot$ the components of the vapr.r field. I(S)

GDT got.

GGMII $\quad\left(\gamma_{\mathrm{v} 1}\right)\left(\gamma_{\mathrm{v} 1}-1.\right)$. S S

GGM12 $\left(\gamma_{\mathrm{v} 2}\right)\left(\gamma_{\mathrm{v} 2}-1.\right)$.

GM11 (Y $\left(\gamma_{\mathrm{V} 1}-1.\right)$.

GM12 (Y 2 ( 1.1 .

I Index $i$. In CØMM

IABRT Abort indicator, set to $I$ if the setup encounters a $\theta<0$. $0, S$

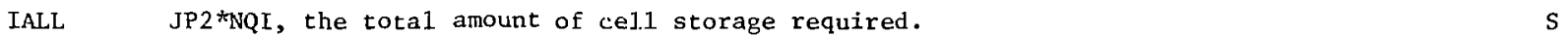

IBAR $\bar{I}$, the number of interior cells in the $r$ direction. $I(0)$

IDT Index For DT and DTףC tables. $\mathrm{S}$

IJ Index for cell $(i, j)$, initialized by $L \emptyset \emptyset$. $L$

IJM Index for cell $(i, j-1)$, initialized by L $\emptyset$ P. $\quad L$

IJP Index for cell $(i, j+1)$, initialized by $L \emptyset \emptyset \mathrm{P}$. $L$

IP1 $\bar{I}+1$, index of rightmost column of interiur cells. $S$

IP2 $\overline{\mathrm{I}}+2$, index of column of exterior cells on the right.

ISPR Short print control, described in Sec. II.G. I(S)

IXL Integer frame coordinate for left edge of plots. $S$

IXR Integer frame coordinate for right edge of plots. S

IYB Integer frame coordinate for bottom edge of plots. $S$

IYT Integer frame coordinate for top edge of plots.

$J \quad$ Index $j$, in C $\emptyset \mathrm{MM} \emptyset \mathrm{N}$ because of ENTRY R1R $\emptyset \mathrm{W}$ ir. $L \emptyset \emptyset \mathrm{P}$.

JBAR $\bar{J}$, the nuaber of interior cells in the $z$ direction.

JNM Job name identification assignerl by the operating system.

JP1 $\bar{J}+1$, index of the topmost row of interior cells.

JP2 $\bar{J}+2$, index of row of exterior cells along the top. S

JRIGID Number of rigid cells up the right boundary; continuative above this point. I(S) 

index.

$\mathrm{JX} 2$

$\mathrm{J} 2+\mathrm{NQ}$, fwa of col. 2 , row $j=2$ (or $2 / 3$ if LCM), set by $L \emptyset \emptyset \mathrm{P}$ as an index.

$=1$ if JCM is used for cell stcrage, $=0$ if SCM is used for cell storage.

NCYC Number of words to tape dump from LCM Lell storage, if used.

NLC Total number of particles in the system at a given instant.

NQL $N Q+N Q$, the number of words in two cells, used by $L \emptyset \emptyset P$, SCM version.

NQ2 NQL + NQL, used as index adjustment if SCM version.

NQ2L

NSC Number of words in this SCM common, for tape dump.

NVAP

OMBS

$=3$ if $\rho_{\mathrm{v} 1}$ and $\rho_{\mathrm{v} 2}>0$. 


\section{RDZSQ $1 / \delta z^{2}$.}




\section{J. Microfilm Plots - Scaling and Subroutine CALLs}

The microfilm plots discussed in Sec. II.G are generally the most useful form of output from our fluid dynamics codes, as they often can quickly convey information about a flow process that would be less readily grasped by examining numerical listings alone.

Our original Computer Output Microfilm (C $\$ M$ ) device is the S-C 4020, which has a matrix of 1024 by 1024 raster points on the rRT face, as is shown in Fig. 13. Usefulness of the 4020 has been increased by addition of a set of three color filters between the tube face and the camera, individually movable under control commands. The III FR-80 c $\emptyset \mathrm{M}$ device has a resolvable matrix of $10 \mathrm{~K}$ by $10 \mathrm{~K}$ points which allows more accurate plotting, and it is also a programmable computer in its own right. For our relatively simple plots, whatever $C \phi M$ is assigned to our offline film output is treated as a 4020, the FR-80 becomirg a 4020 simulator when used in this manner. Therefore, the following description of our plot scaling is based on the $\dot{0} 20 \mathrm{film}$ frame of Fig. 13.

Note from Fig. 13 that the origin of the $x-y$ coordinate system lies at the upper left corner of the frame and the values of the two integer indices increase to the right and down. This coordinate system obviously does not match that of the fluid

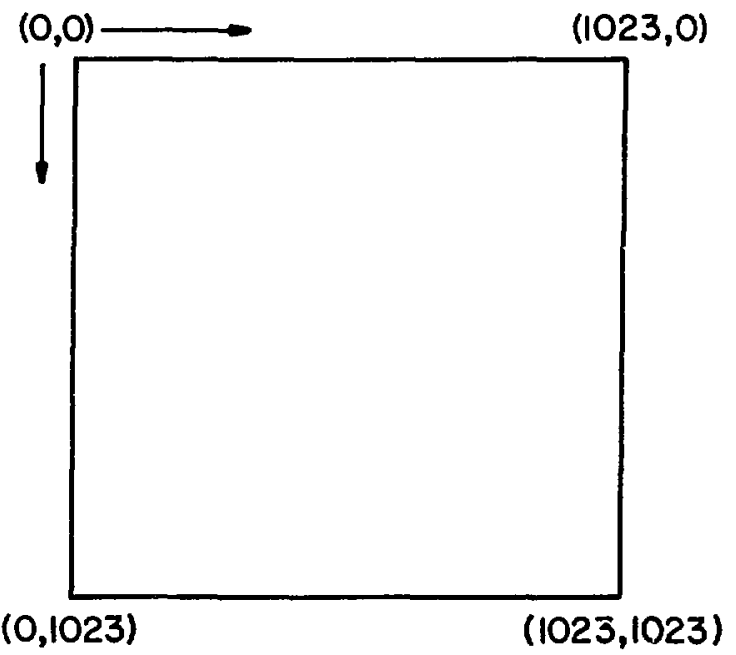

Fig. 13. The 4020 grid is a reflection of the first quadrant, and contains a matrix of 1024 by 1024 raster points, with the origin located at the upper left corner. $x$ increases to the right, and $y$ increases downward. dynamics computing mest shown in Figs. 1 and 8, where the origin is at the lower left corner. A conversion from physical mesh position to a corresponding 4020 frame position is required for all plotting. In KACHINA, the left, bottom, right, and top edges of the physical nesh are specified by:

$\mathrm{XL}=\mathrm{YB}=0.0$.

$X R=\bar{I} \delta r$,

$\mathrm{YT}=\overrightarrow{\mathrm{J}} \delta \mathrm{z}$,

and their counterparts in 4020 coordinates are given by the integers IXL, IYB, IXR, and IYT, calculated in accordance with the following considerations. First, we reserve areas across the top and bottom of the frame for piot identiflcation, problem time, cycle number, and so forth. These are indicated by the shaded areas in Fig. 14. (The technique for generating alphanumeric information in these regions is discussed below.) The unshaded area that remains is $: 024$ points wide by 900 points high, although we consiler the available width to the 1022 points, to ensure frame separation. Second, within this rectangular region, we maximize the size of the plot that is drawn, while maintaining its true physical proportion of height to width. Thus, if the physica? area encompassed by the computing mesh is higher than it is wide, $\mathrm{XR}<\mathrm{YT}$, the resulting plot occupies the region exemplified by the fine shading in Fig. 15 . The coordinates in this case are given by:

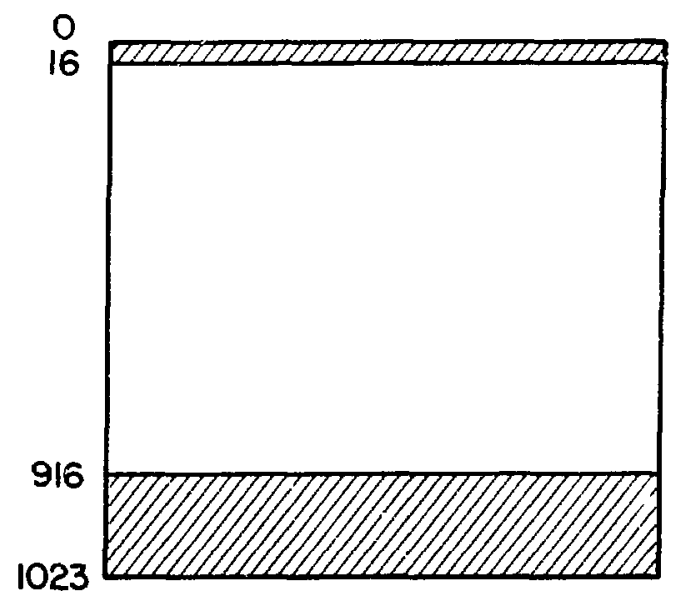

Fig. 14. The area in the center, available for plotting, enconpasses 1024 by 900 raster points. The shaded areas are reserved for labeling, allowing two lines at the top and six at the bottom. 


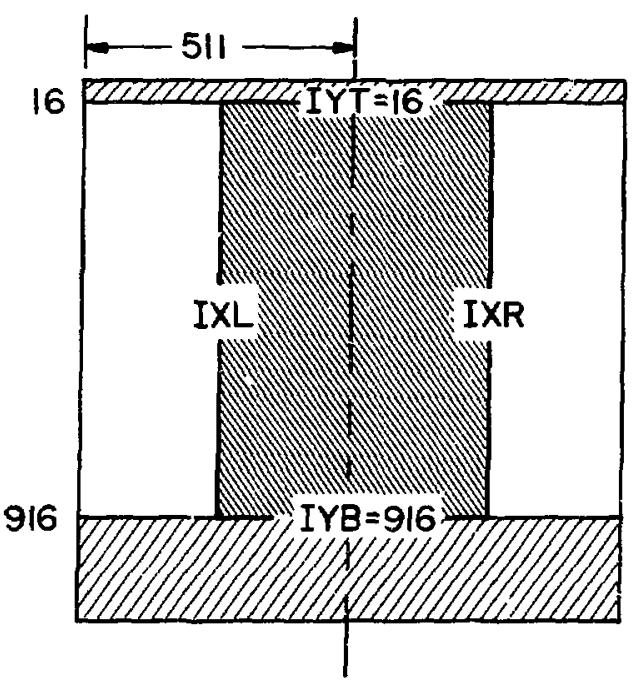

Fig. 15. The plotting area when the computing mesh is higher than it is wide, XR $\angle \mathrm{YT}$.

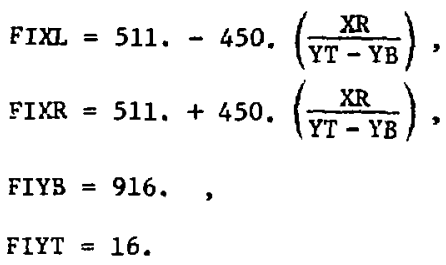

Conversely, if the computing area is wider than it is high, XR > YT, the plot occupies the region exemplified by the fine shading in Fig. 16. Here the coordinates are given by:

FIXL $=0$,

FIXR $=1022$.

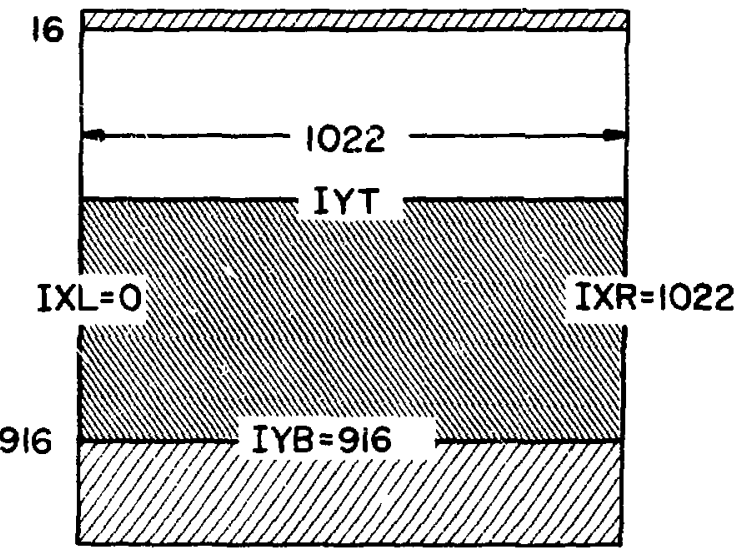

Fig. 16. The plotting area when the computing mesh is wider than it is high, XK $>\mathrm{YT}$.
FIYB $=916$.

FIYT $=916 .-1022 \cdot\left(\frac{Y T-Y B}{X R}\right)$.

In either case, the equivalent integers IXL, IXR, IYB, and IYT are then simply set directly from FIXL, FIXR, FIYB, and FIYT. The "4020 Setup" in SETUP calculates these eight quantities, and then calculates the two conversion factors that w1ll be required for translating physical mesh coordinates to 4020 frame coordinates. These are given by the ratios

$X C \emptyset N V=(F I X R-F I X L) /(X R-X L)$,

and

$Y C \emptyset N V=(F I Y T-F I Y B) /(Y T-Y B)$.

A physical mesh coordinate is multiplied by the appropriate factor to convert it, and this product is then added to FIXI or FIYB and the sum is converted to an integer to locate the position on the 4020 frame of Fig. 13. A conversion subroutine is available that would handle this task for us, but it is more efficient for KACHI:A to do it, thus avoiding recalculation of these two ratios whenever a point is plotted or a vector segment is drawn.

A set of local software subroutines provided by the Computer sciences and Services Division of the Los Alamos Scientific Laboratory handles the communication between the problem program and the $C \emptyset \mathrm{M}$ devices by producing 4020-format commands. RACHINA uses a number of these subroutines, which are accessed by the following FøRTRAN calling sequences.

CALL ADV ( $n f$ ) advances the film by nf frames. CALL FRAME (IXI, IXR, IYB, IYT) draws a rectangular outline of the computing mesh. Two horizontal axes are drawn through IYT and IYB from IXL to IXR, and two vertical axes are drawn through IXL and IXR from IYT to IYB.

CALL PLT (IX, IY, ch) plots the 4020 character identified by $c h$ at 4020 frame coordinates (IX, IY).

CALL DRV (IXI, IY1, IX2, IY2) draws a straight line vector segment connecting the 4020 point (IX1, IY1) with the 4020 point (IX2, IY2). 
CALL $C \emptyset L \emptyset R$ (c) controls the filter selection for color processing; $c$ is a floating-point variable with a value in the range 0.0 to 4.0 . Single-filter selections are determined as follows: $c=0.0$ No filter (white), $c=1.6$ Yellow filter, $c=2.6$ Cyan filter, $c=3.6$ Magenta filter.

The primary colors are obtained by appropriate filter combinations: $c=1.0 \operatorname{Red}(=$ yellow + magenta), $c=2.0$ Green $(=$ yellow + cyan $)$, $c=3.0$ Blue (= cyan + magenta).

Several additional subroutines are available for writing alphanumeric information on the frame. Whereas some of these write large characters composed of dot patterns, the basic CRT tube has a set of small alphanumeric characters that can be generated in the "typewriter" command mode, and it is this latter form that is used in KACHINA. In typewritrr mode, the 4020 frame of Fig. 13 is composed of 64 lines of 128 characters each. Each character occlsies; a rectangular region 8 raster points wide by $16 \mathrm{high}$. The first character of a line is treated as a carriage control, completely analogous to line printer use.

CALL LINCNT $(\ell)$ locates the first column of line $\ell$, where $\ell$ ranges from 0 (top Iine of the frame) through $\ell=63$ (bottom line of frame), and $k=64$ advances the film to the top of the next frame. After LINCNT locates the desired stcrting line position, ordinary formatted WRITE statements generate the actuai alphanumeric information. The FORMAT statements are identical to those appropriate for a line printer, provided the 128 character per line restriction is observed. Line advancement is automatic, as on a line printer, until either line 63 has been written on, after which the film is automatically advanced to the top of the next frame, or another CALL LINCNT Is issued to specify any desired line $(0-63)$ of the current frame.
CALL EMPTY ensures that if the film buffer contains any words, they are written on the 4020 tape. EMPTY generally appears as the final command to a sequence of 4020 instructions. Thus no residual commands are left in the film buffer, where they would be susceptible to possible loss in the event of a hardware or system failure.

\section{K. Miscellaneous System Subroutine CALLs}

KACHINA uses a number of other CALLs to access various local operating system subroutines not directly related to microfilm usage. These are, briefly, as follows.

CALL GETQ (key, q) (Get Quantity) is available for retrieving a variety of job task parameters from the operating system. Here, key is the task parameter identifier, in left-justified display code, and $q$ is the name of the problem program location to which the value of the quantity is returned. In KACHINA, we use two task parameters: $\mathrm{KJBN}$ is the job name, composed of 10 symbols, the first 7 symbols from the job card name field, followed by a one-digit input station ID and a two-character job sequence number. KTLM is the time limit specified on the job card, converted to CDC 7600 rlock cycles, where one clock cycle $=27.5 * 10^{-9}$ seconds.

CALL DATE1 (D1) stores the current date in display code in the location specified by $\mathrm{Dl}$. The form is eight characters, $\mathrm{MM} / \mathrm{DD} / \mathrm{YY}$, where $\mathrm{MM}$ is the month, $\mathrm{DD}$ is the day, and $Y Y$ is the year.

CALL CL $\emptyset$ CKl (Cl) stores the current time of da: in display code in the location specified by $\mathrm{Cl}$. The form is eight characters, $\mathrm{HH} \cdot \mathrm{MM} \cdot \mathrm{SS}$, where $\mathrm{HH}$ is the hour (00 through 23), MM is the number of minutes, and $S S$ is the number of seconds. 
CALL SEC $\emptyset \mathrm{ND}$ (TI) stores the elapsed central processor time for the job in the locaition specified by $T I$. This time is expressed as a real number representing stconds, to the nearest thousandth of a second.

CALL AFSREL ( ), or Active Fileset Release, is used in two ways in KACHINA. First, upon a tape restart, it is called to release LCM space the the operating system has devoted to Fileset 7 , as soon as that fileset becomes inactive. Second, it is also called to initiate output processing of active filesets OUT and FILM at each tape dump, assuming that the dump is before job completion and is an intermediate one.

CALl DATAREL ( ), or Data Release, is used to stage a restart dump from the disk onto a physical tape. Ocherwise, tape dumps would be accumulated on disk storage during job execution and not actually staged to tape until job completion, leaving them vulnerable to loss in event of hardware or system failure.

If the descriptions of system subroutines provided in Secs. II.J and II.K are inadequate, contact the Los Alamos Scientific Laboratory Computer Sciences and Services Division.

\section{REFERENCES}

1. F. H. Harlow and A. A. Amsden, "A Numerical Flui Dynamics Calculation Merhod for All Flow Speeds, J. Comp. Phys. 8,197 (1971).

2. A. A. Amsden and C. W. Hirt, "YaquI: An Arbitrary Lagrangian-Eulerian Computer Program for Fluid Flow at All Speeds," Los Alamos Scientific Laboratozy report LA-5100 (1973).

3. c. W. Hirt, A. A. Amsden, and J. L. Cook, "An Arbitrary Lagrangian-Eulerian Computing Method for A11 Flow Speeds," J. Comp. Phys. 14, 227 (1974).

4. T. D. Butler, 0. A. Farmer, and W. C. Rivard, "A Numerical Technique for Transfent, Chemically Reactive Flows of Arbitrary Mach Number," manuscrlpt in preparation.

5. J. U. Brackbill and W. ' Pracht, "An Implicit, Almost-Lagranglan Algor i for Magnetohydrodynamics," J. Comp. Phys. 1,, 455 (1973).

6. F. H. Harlow and A. A. Amsden, "Multi-Fluid Flow Calculations at All Ma.h Numbers," J. Comp. Phys., accepted for publication.

7. F. H. Harlow and A. A. Amsden, "Numerical Calculation of Multiphase Fluid Flow," J. Comp. Phys., accepted for publication.

8. C. W. Hirt, "Heuristic Stability Theory for Finite Difference Equations," J. Comp. Phys. 2, 339 (1968).

9. F. H. Harlow and A. A. Amsden, "Fluld Dynamics A LASL Monograph," Los Alamos Scientific Laboratory report LA-4700 (1971).

10. C. W. Hirt and J. L. Cook, "Calculating ThreeDimensional Flows Around Structures and Over Rough Terrain," J. Comp. Phys. 10, 324 (1972).

11. A. A. Amsden and F. H. Harlow, "The SMAC Method: A Numerical Technique for Calculating Incompressible Fluid Flows," Los Alamos Scientific Laboratory report LA-4370 (1970). 
APPENDIX A

FLOW DIAGRAM FOR THE KACHINA PROGRAM

(June 19, 1974 Status) 
$\hat{N}$

KACHINA - A MULTI-FIELD HYDRO CODE

(1)

PROGRAM KACHINA - 0,0 OVERLAY:
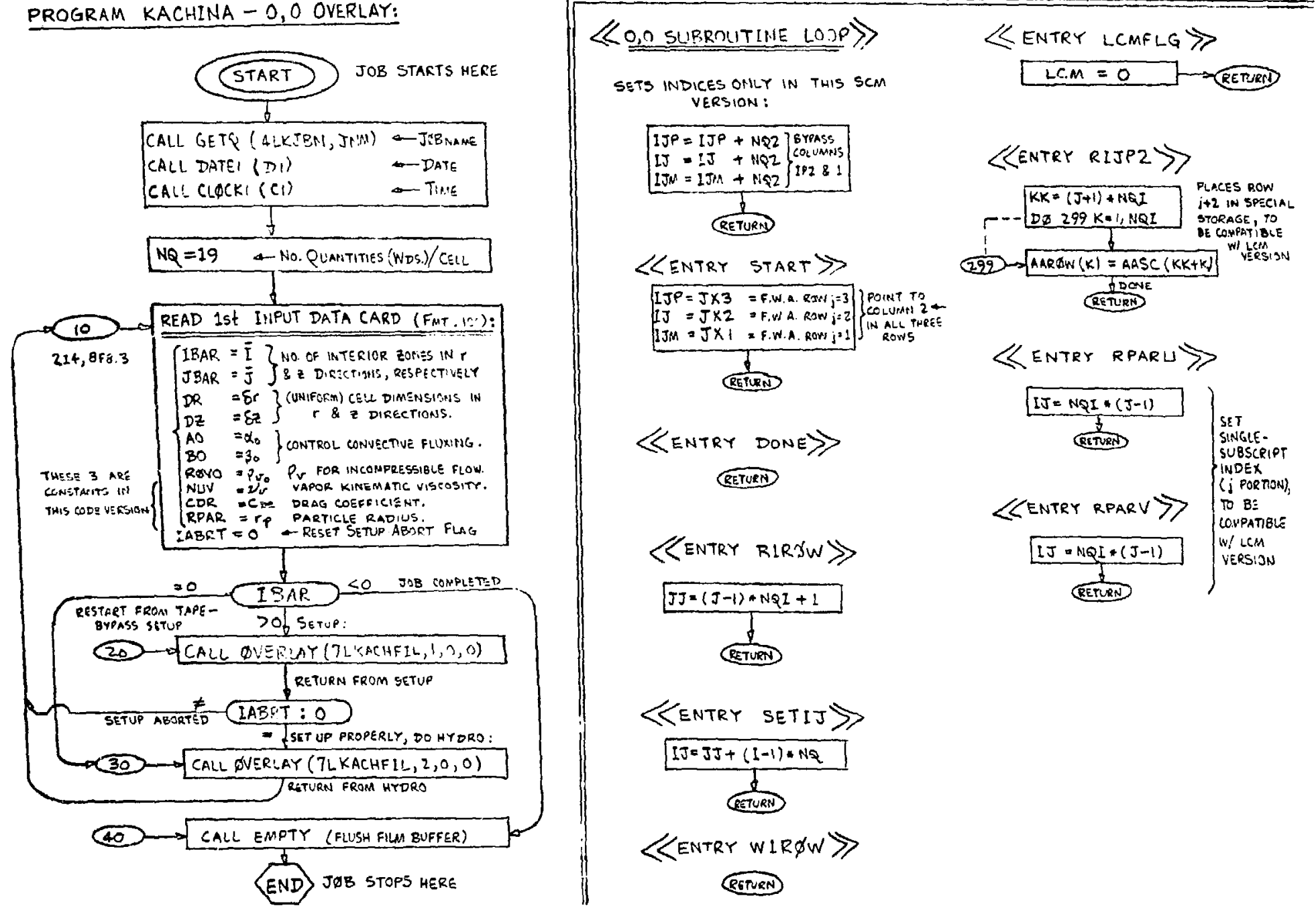


\section{1,0 OVERLAY - The PROBLEM SeTUP:}

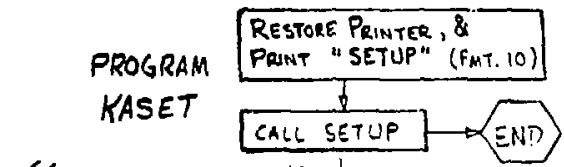

\section{$\langle$ SUBROUTINE SETUP $\rangle \downarrow$}

CALL LCMFLG SETS LEM FLAO

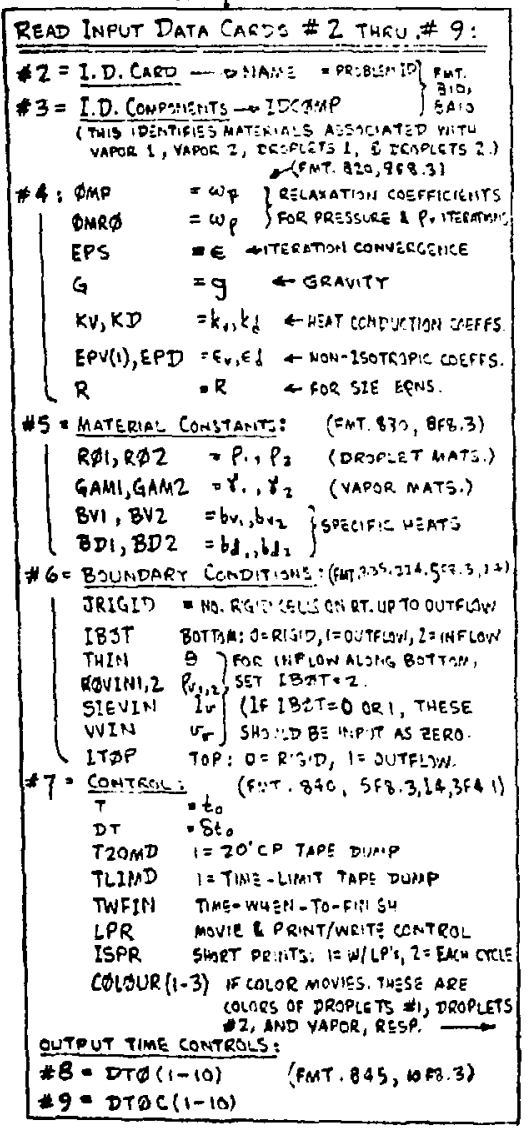

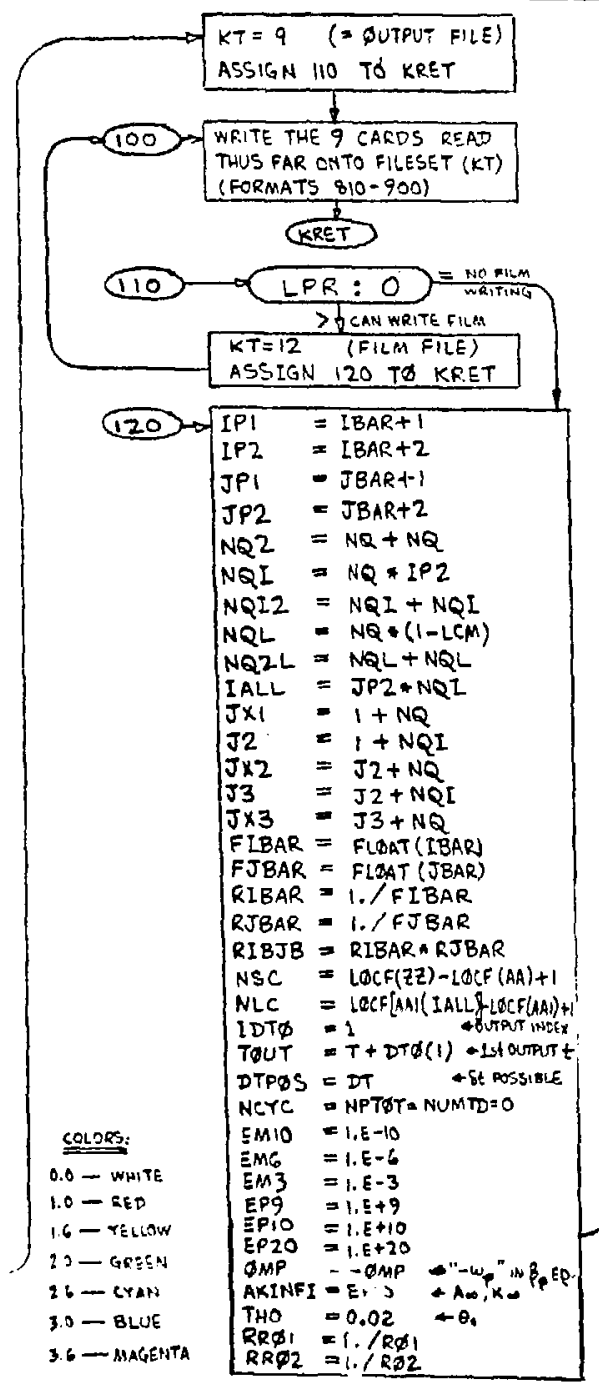

$R R Q 1=1,1 R \phi 1$
$R R Q 2=1,18 p 2$

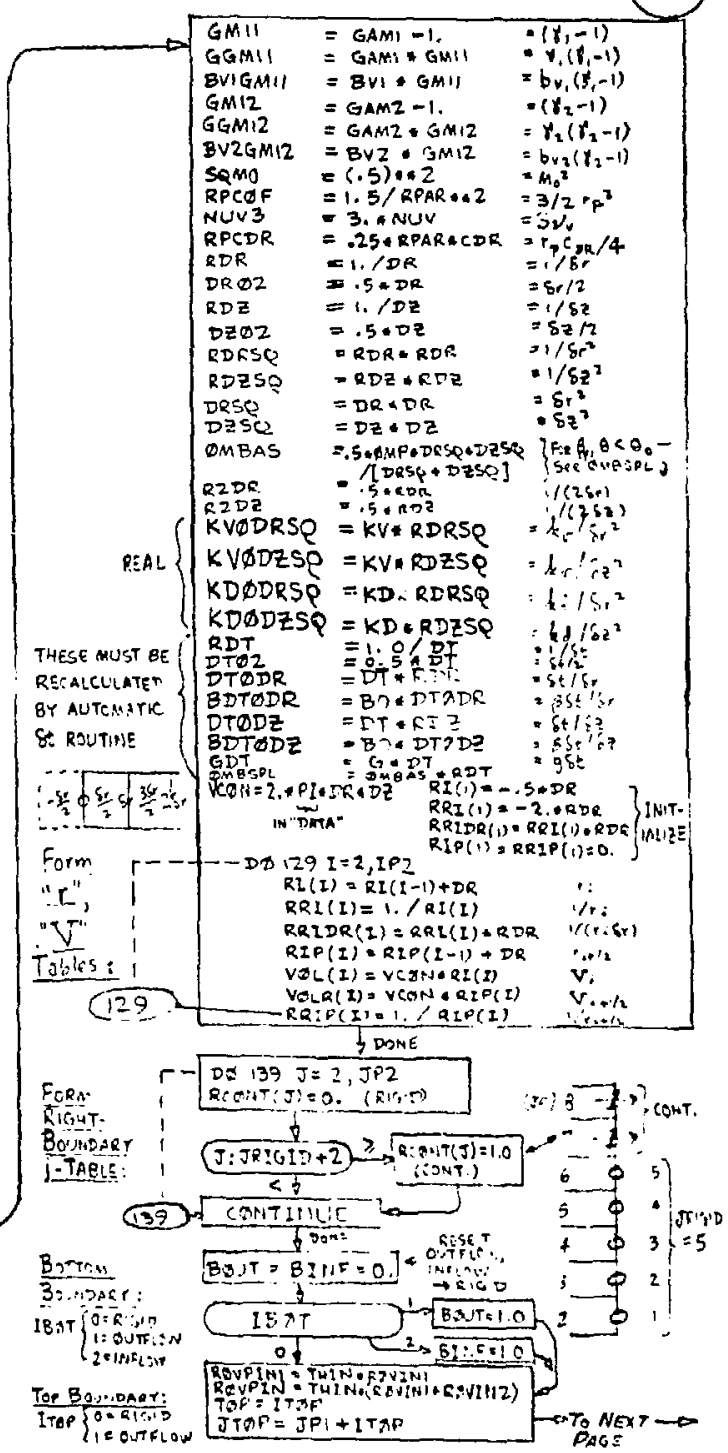




\section{1,0 OVerlat - The Problem Setup-Continued:}

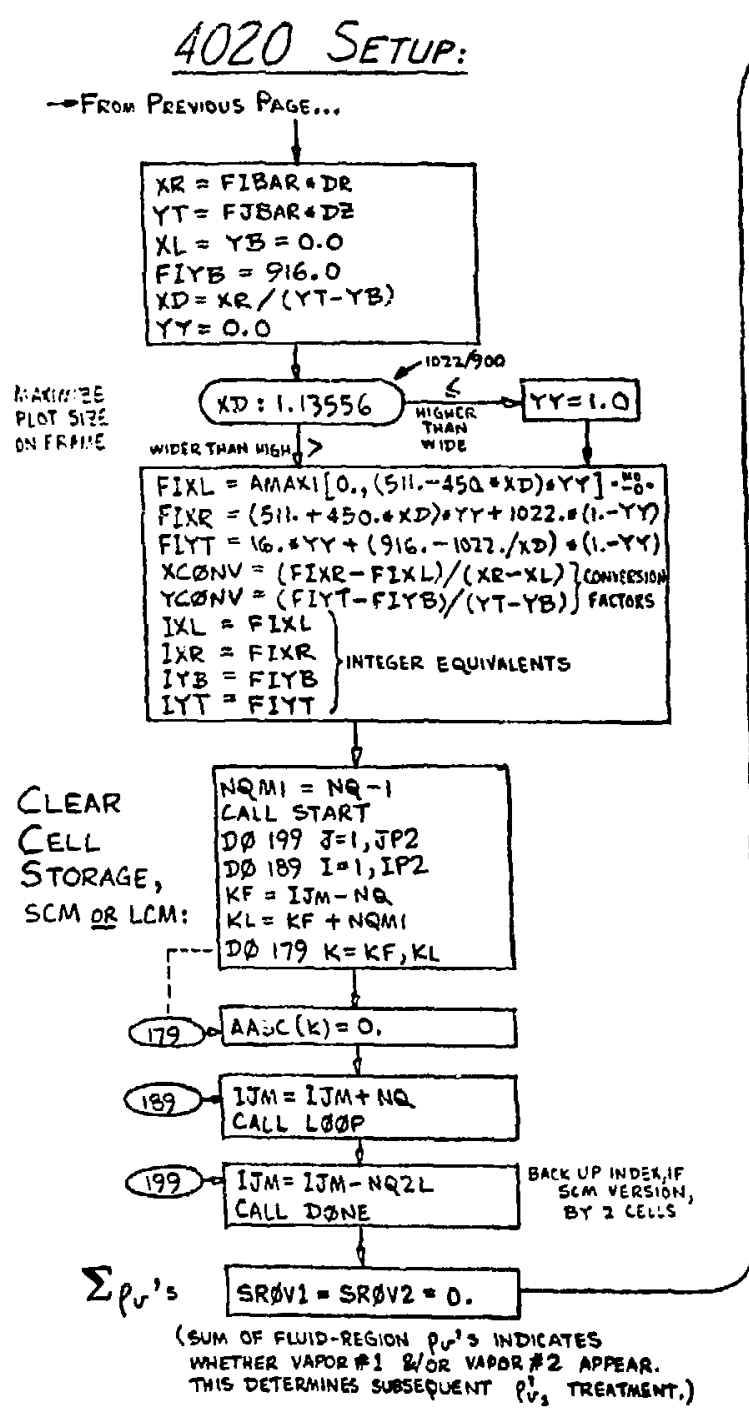

200

READ A GLUID-REGION GARD

(f-t. 910)

$414,678.3,14$

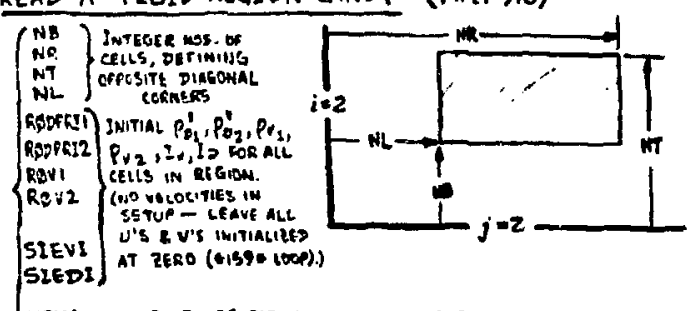

NPUA WO DaeticLSS DiR UNHT AREA - REFER tO MEET PAGE

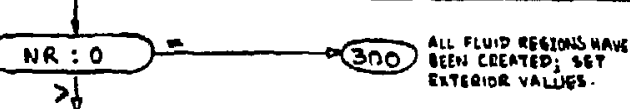

PRINT CENTENTS Of ABOVE CRRD. Fonmat 920

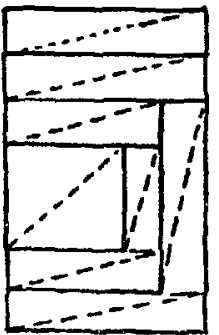

Exasple Jf A TYMICAL SETuP I -

i6 FLUID RESOHS, WUT Re्pureD.)

and $P_{r_{1}}, P_{12}$

inTO R:ining

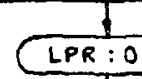

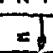

SROVI $=$ SROVI + ROV

DON'T ALTEK

NB, NE, NIT GA IIL

SRSV2 $=$ SROVI + RQV2

paktikle genickater? NLL - NL+ Z

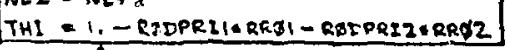

THI:0.0 — 400 INAUT BAD - ABONT HI WESSAGE.

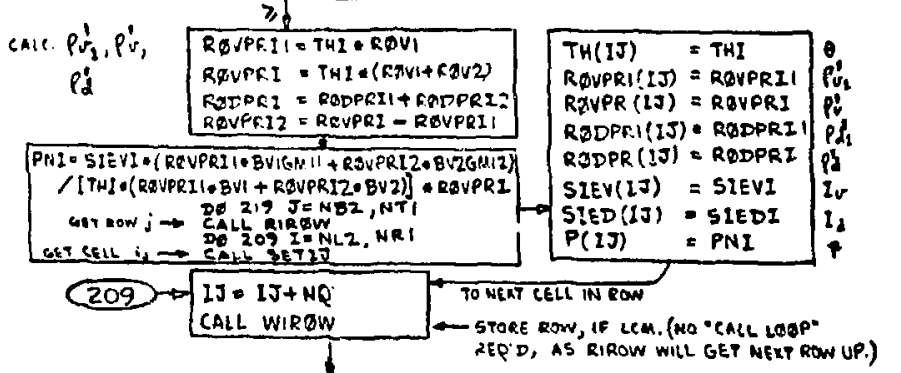

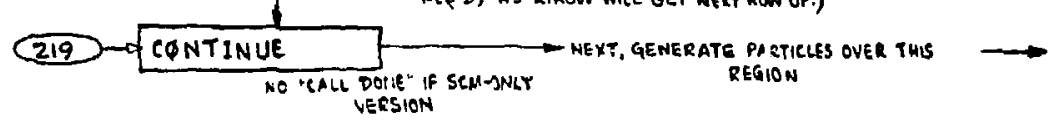



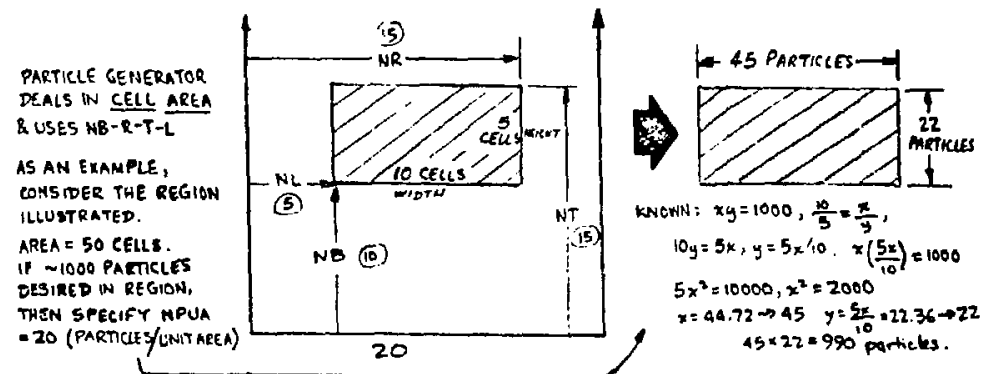

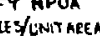

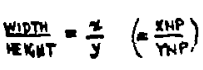

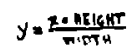

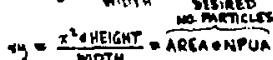

NAQSE 30 (234) PNEFF = FNPUA *THZ

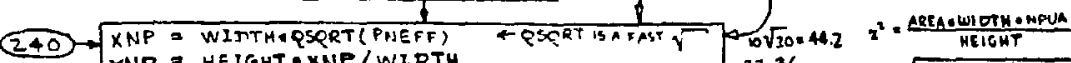

YNP $=$ HEIGHT O XNP/WIDTH
NPX $=$ XNP + .5 + EMIO NO. OF PARTILLES IN EACH

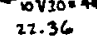

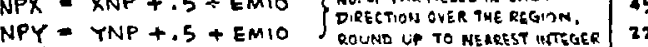

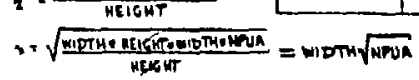

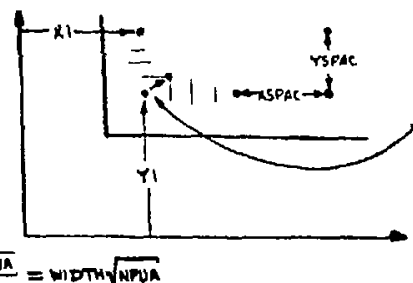

1 Mar WISU TO OEFSES ONE SDT GF PACTELES GESERALT
THIS IS UNNEE ESSART, AS PNEFF'S GENERALUY DIFFER, AND SEPACATE PLOTS ARE MADE (OFFSET $=\frac{\text { XSPAC }}{4}, \frac{\text { YSPAC }}{4}$ ) 


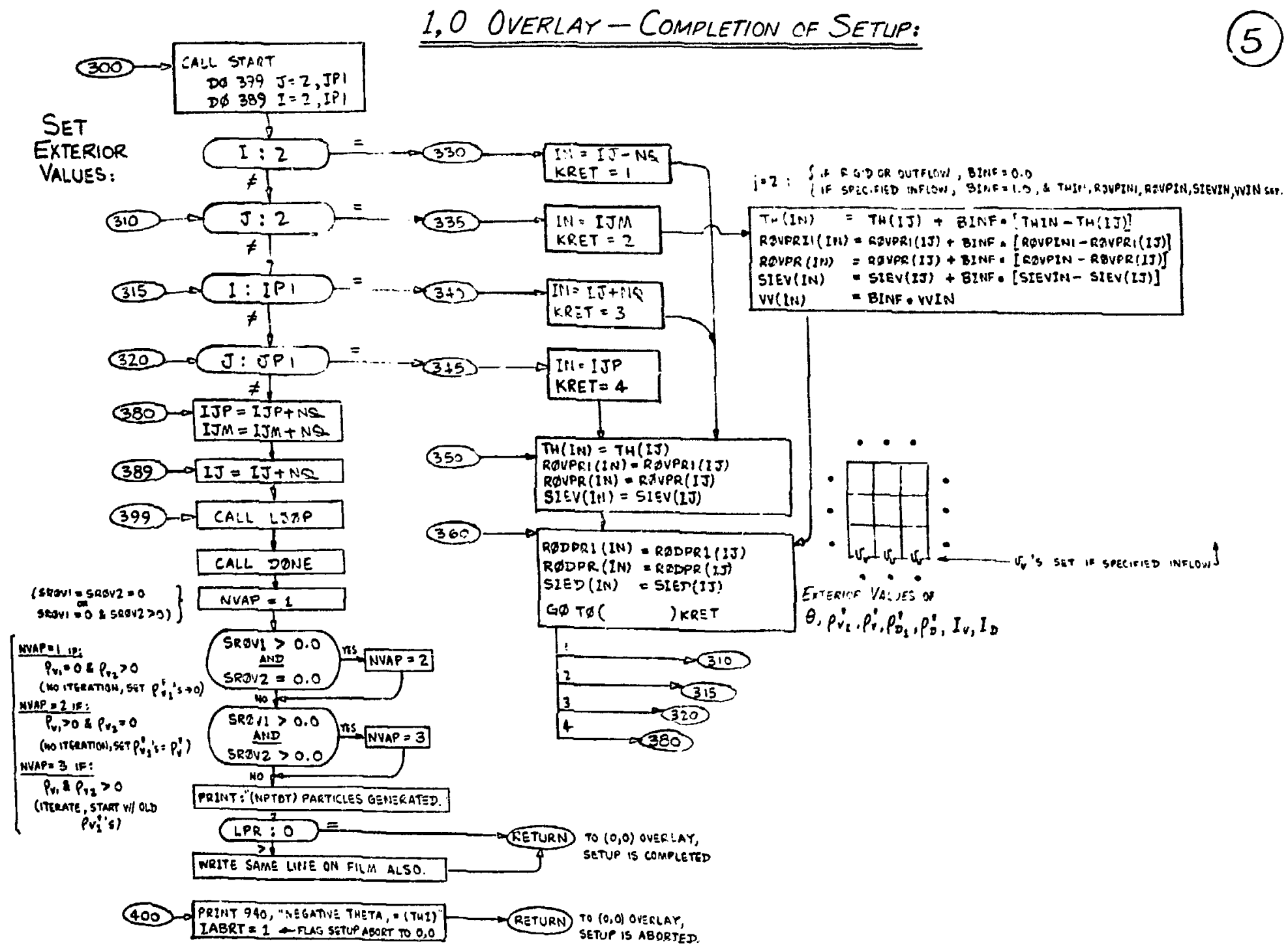




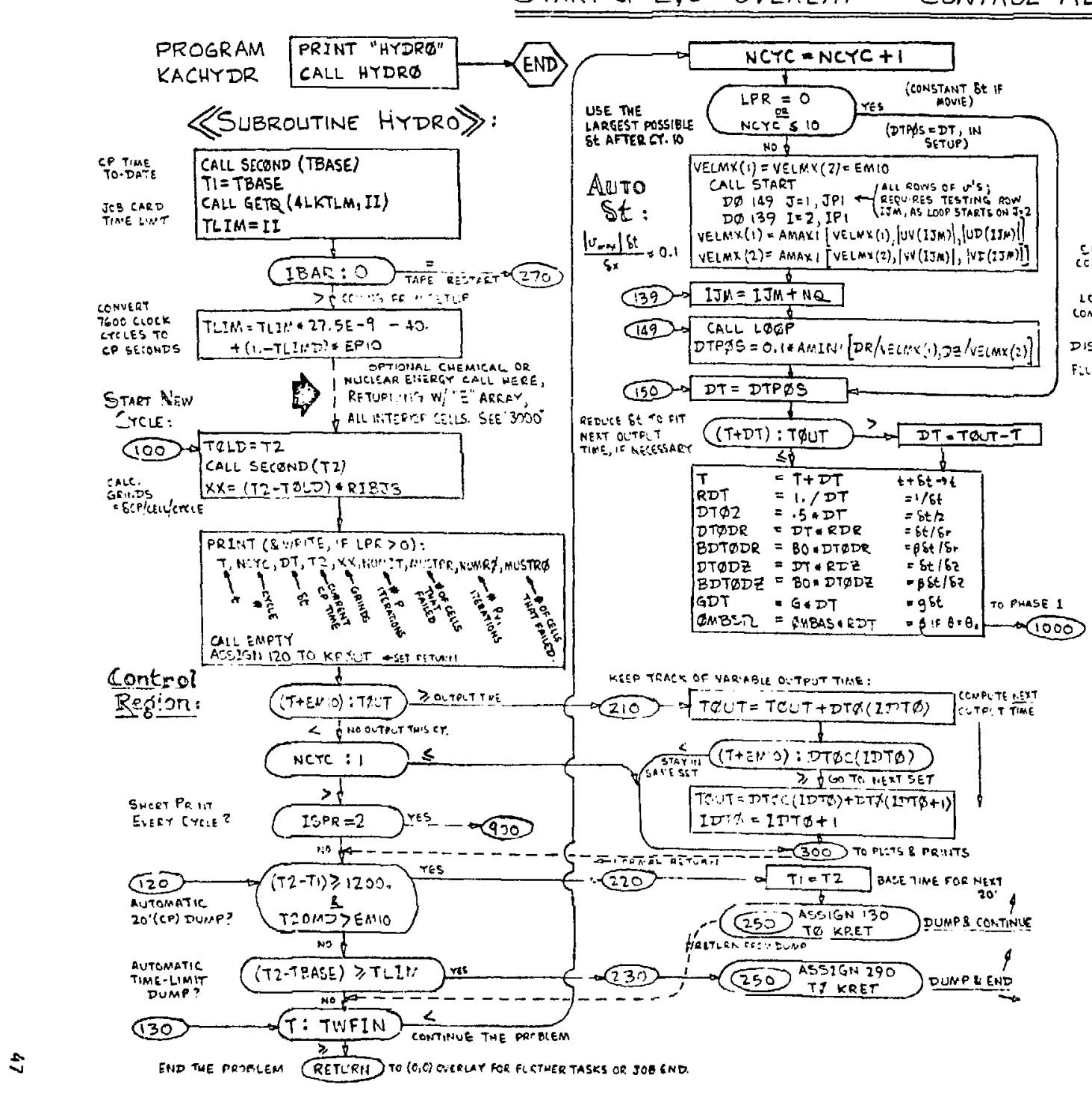

\section{Tape Dump:}

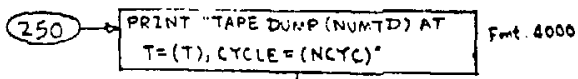

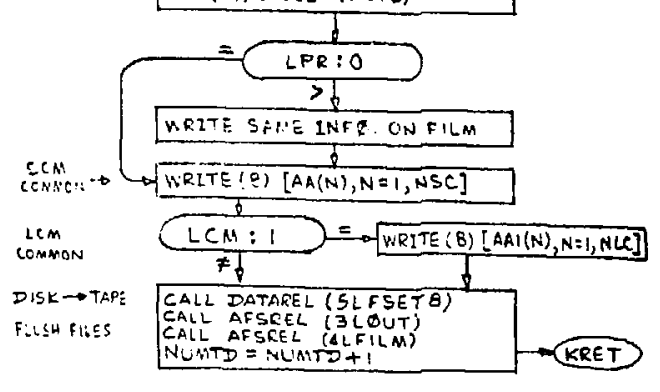

\section{Tape Restart:}

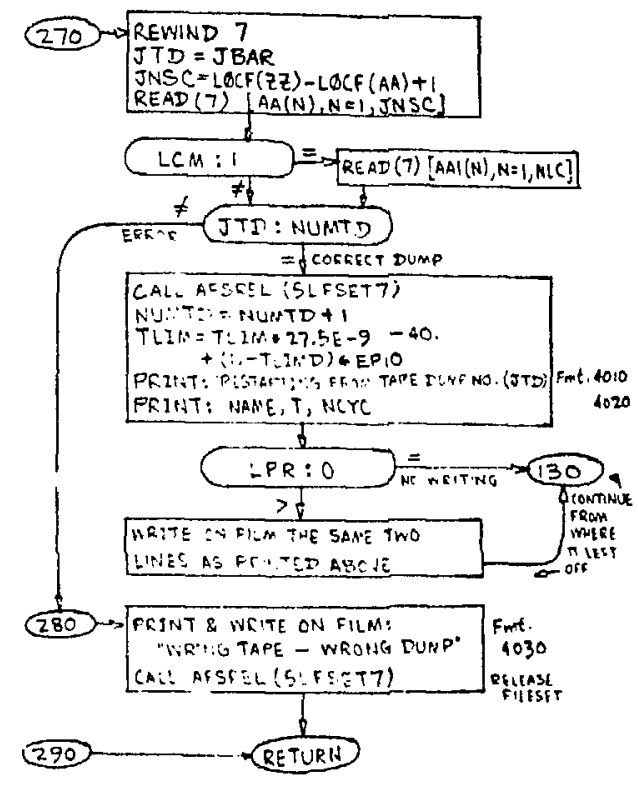



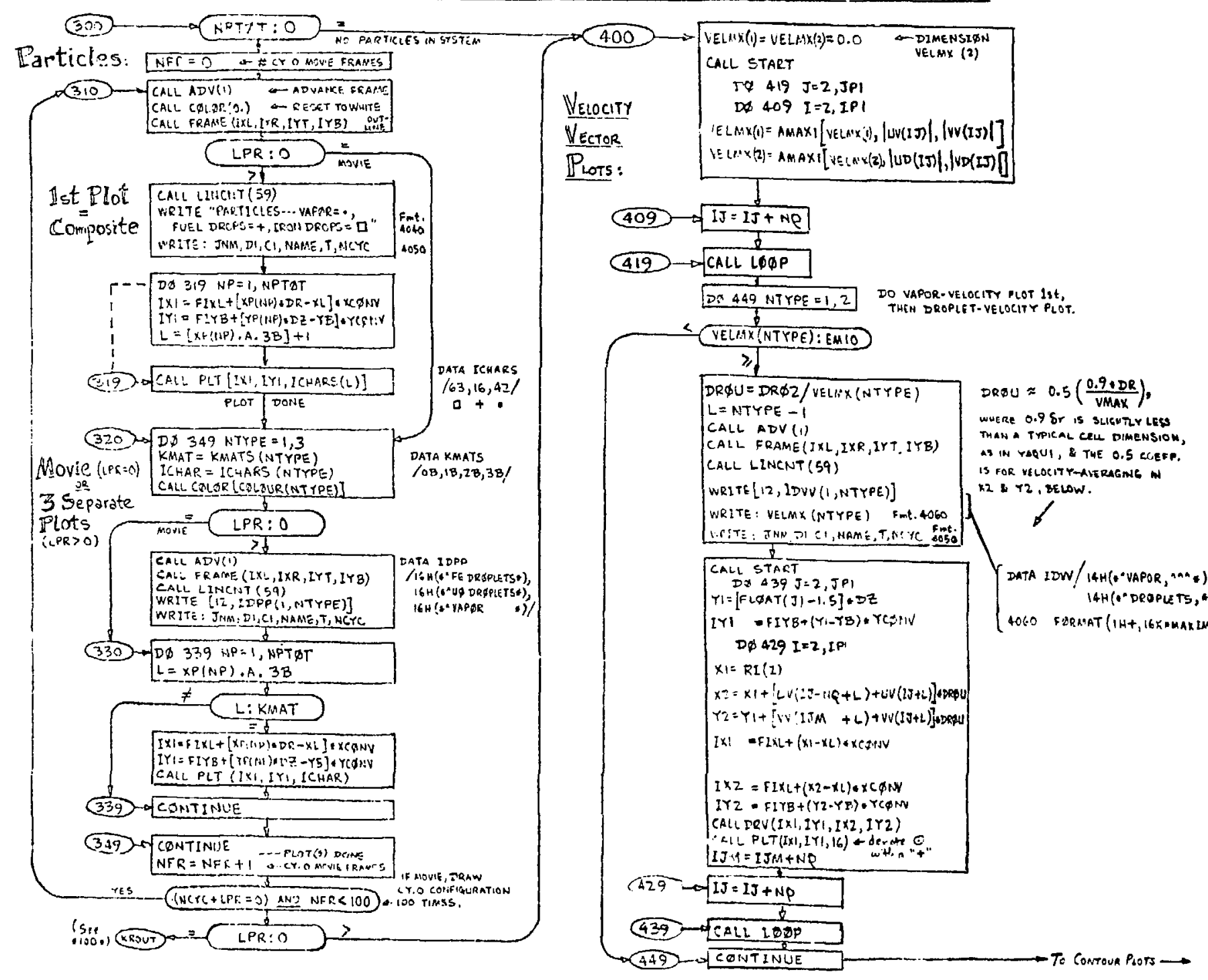


\section{Contour Plots - page 1 of 2 :}

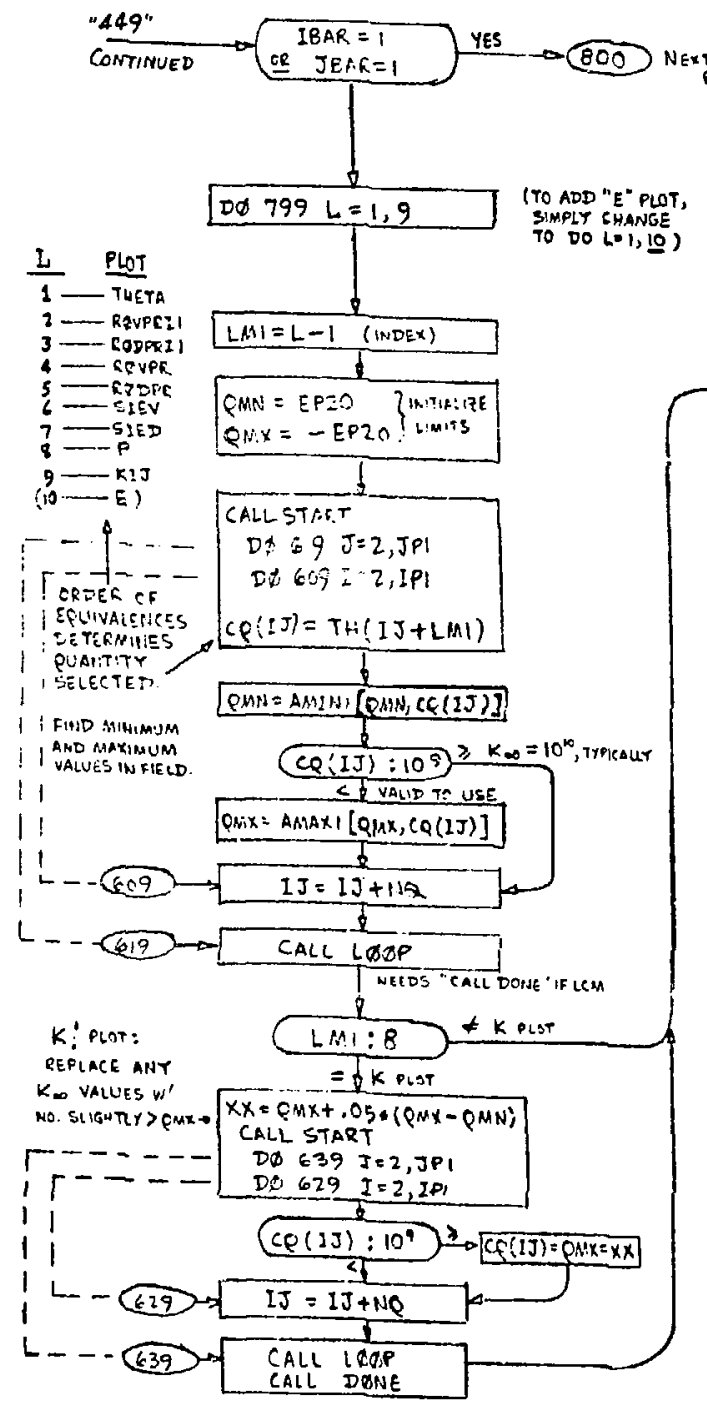

$$
\begin{aligned}
& \text { WILL WRITE: } \\
& \text { (C } 14 \text { CHARS.) } \\
& \text { WHERE: }
\end{aligned}
$$

DINERER $\operatorname{tresn}(2,10)$
(LINEAR PLOT)

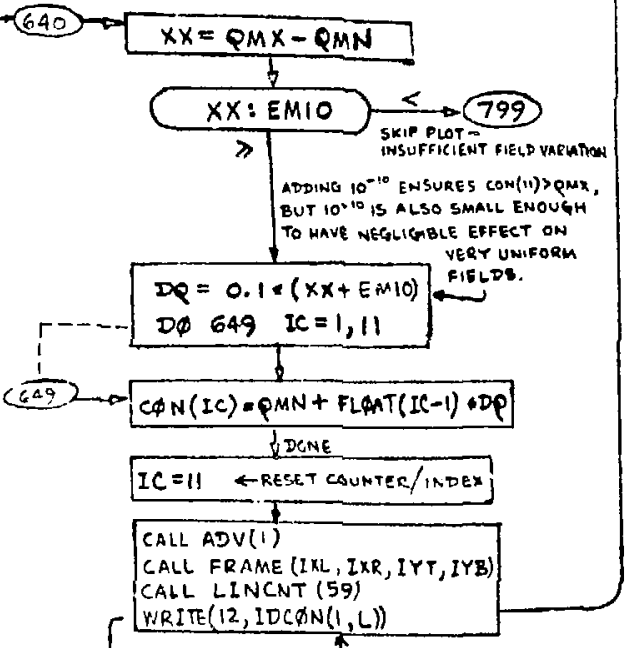

$52 / 2+$\begin{tabular}{|c|c|}
\hline IJP & IPJP \\
\hline $\int_{6 T / 2}$ & IJ \\
\hline & IPJ \\
\hline
\end{tabular}

$D 4769 \mathrm{IK}=1, \mathrm{IC}$

$k_{1}=k_{2}=k 3=k_{4}=0$

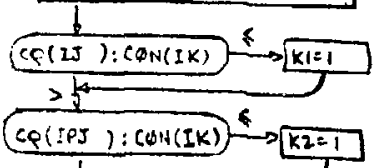

CQ(IP) ) : CQNA (IK) $\rightarrow K_{2=1}$

$$
>\text { hen }
$$

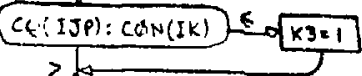

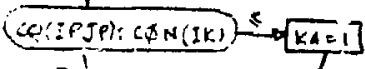

product $\neq 0$, HEN AL Four if SUM $=0$, THEN ALL FOUR
ACE $=0$.

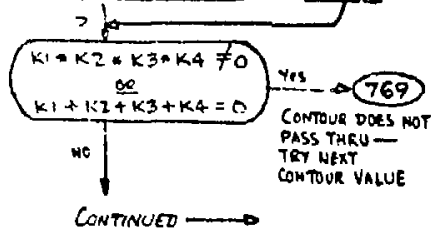

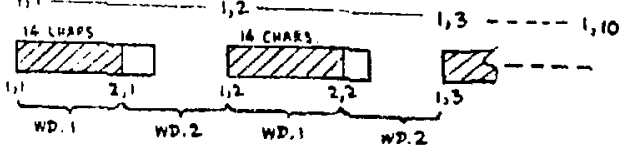

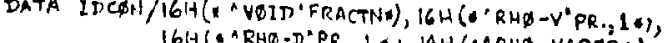

$$
\begin{aligned}
& 161 \text { (ARHQ-DAPR, } 1 \text { (A), 14H (AAR!1, -VAPQR+), }
\end{aligned}
$$

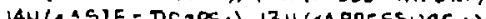

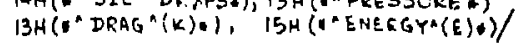




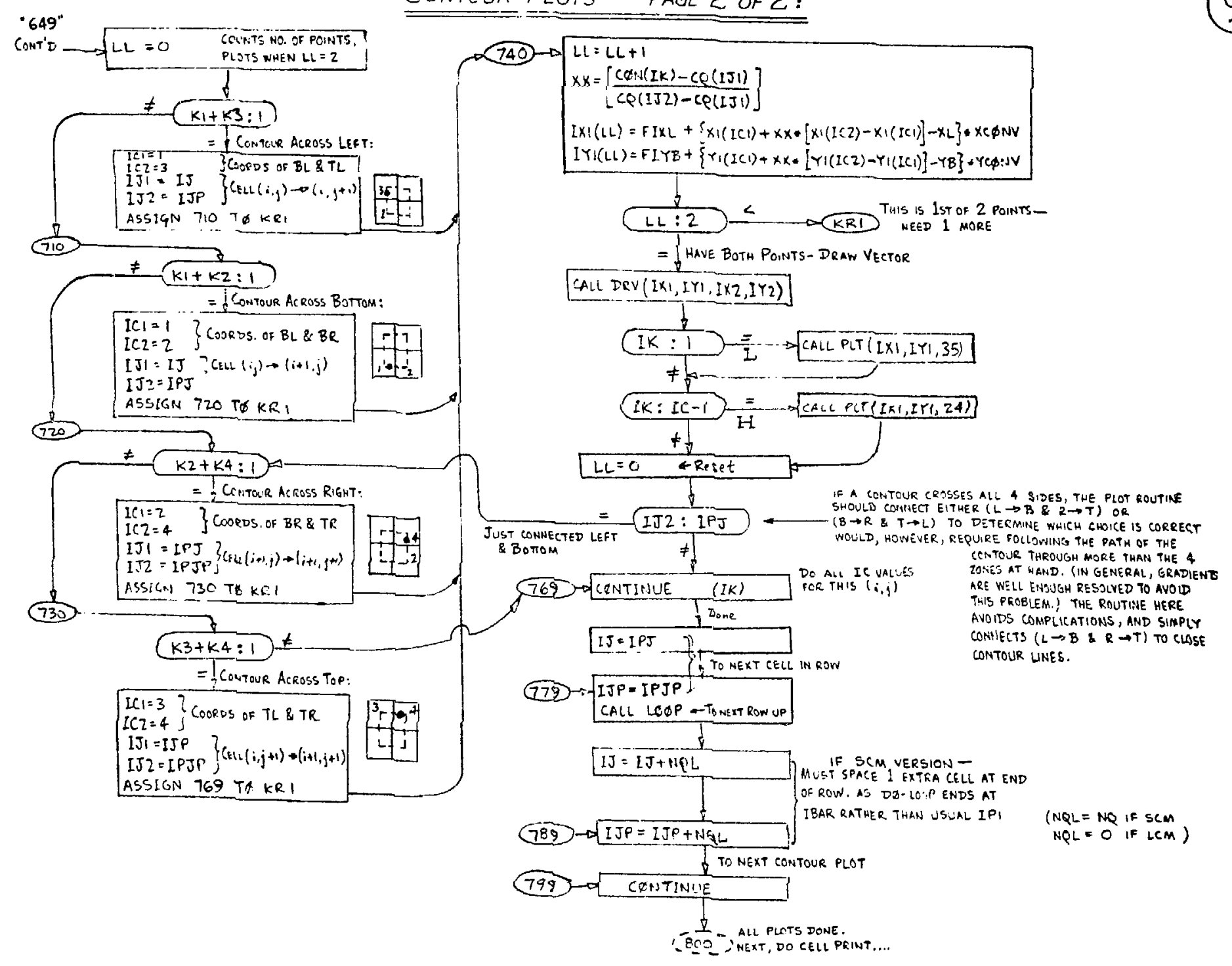




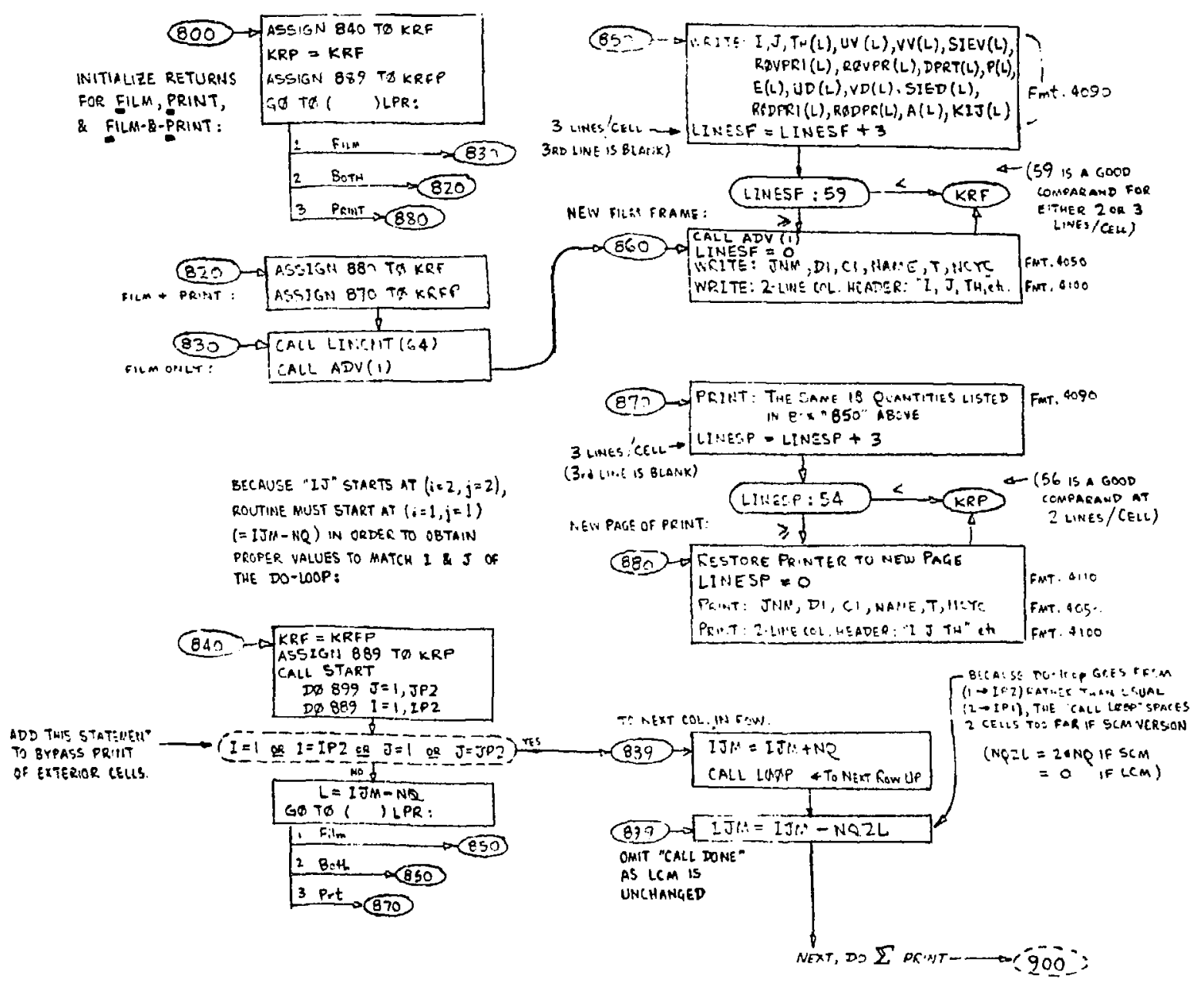




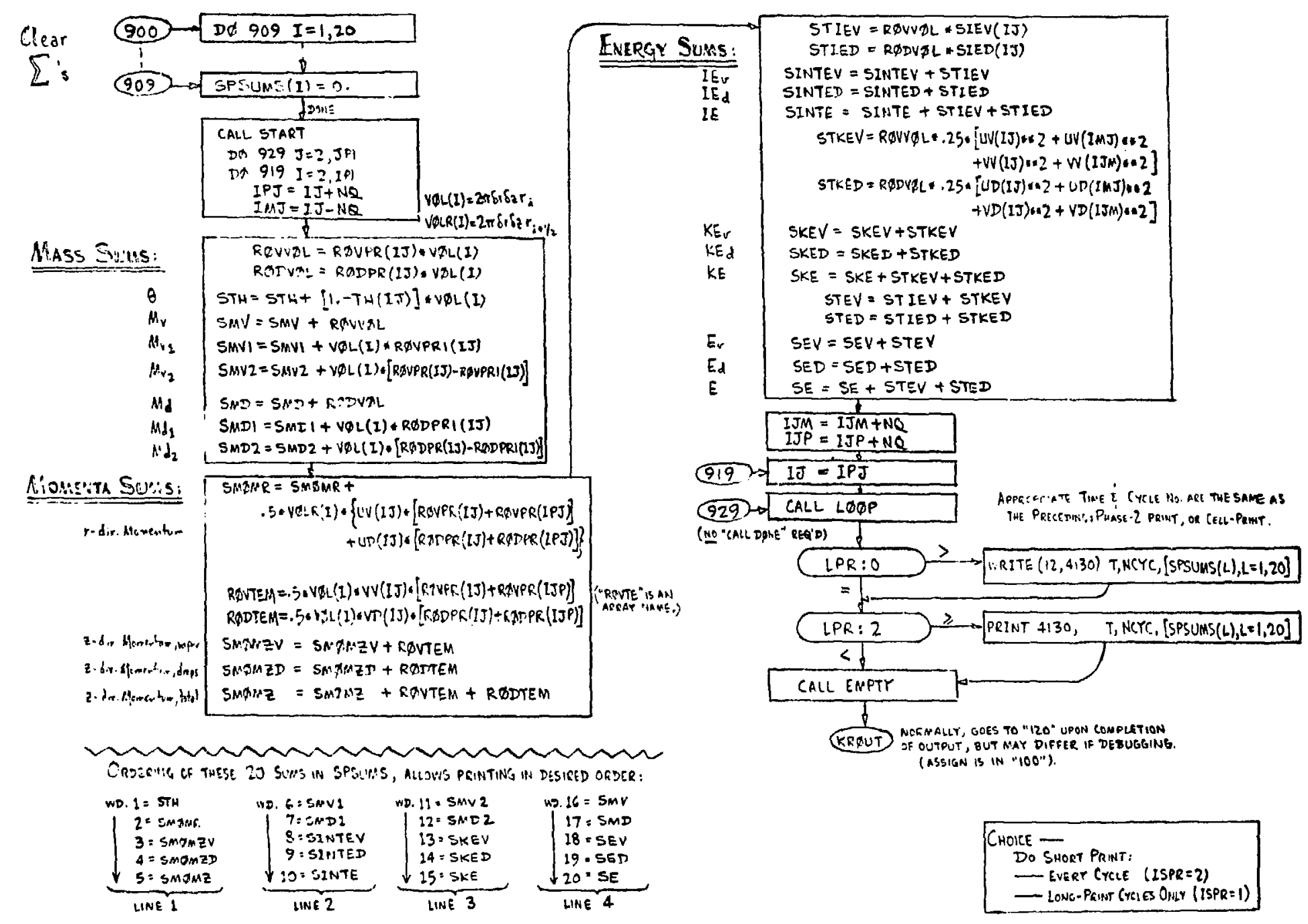


PhASE $1-P .1-$ CaLCULATE $\rho_{D}^{\prime}, \rho_{D 1}^{\prime}, \theta, A, \tilde{p}, K:$

BEGIN

NEW

CYCLE:

\begin{tabular}{|c|}
\hline 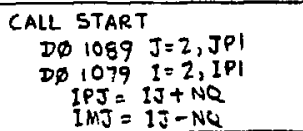 \\
\hline
\end{tabular}

\begin{tabular}{|c|}
\hline 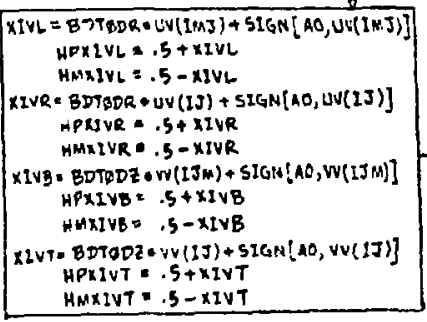 \\
\hline
\end{tabular}

COLLECT TERPS FIR

CONVECTYYE FLUXES

NERT, CALC. ${ }^{n+1} P_{D}^{\prime} 1^{n+1} P_{D_{1}}^{\prime}{ }^{n+1} \theta \ldots$

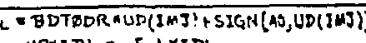
$H P X I D L=.5+\times I D L$

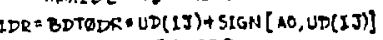
APXIDR $=.5+\times 2 D Q$

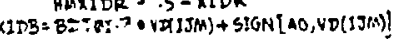

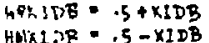

$x I D T=$ SDTADZ, $V D(L J)+S I G N[A O, V D(I J)]$ HPXIDT $=.5+\times 1 D T$ HMXIST - . 5 - XIDT

UGRR $=\operatorname{UV(IJ)!RIP(I)}\left(u^{2}\right)^{i+12}$

$J V R L=U V(I M J) \cdot R I P(I-1) \quad\left(\omega_{*} \cdot r\right)_{1-1} / 2$

UDRR $=U \Gamma(I J) \cdot R$ RIP(I) (udt).oth

UDRL $=U D(I M J) \cdot R I P(I-1) \quad\left(u_{2}\right)_{i} \cdot L_{L}$

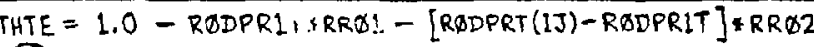

(ब)

\section{LR=1. LRQVPR(2J)}

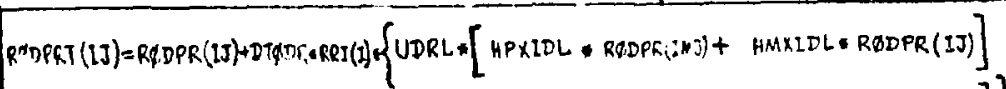

- UDRP: $[H P X I D R+R Q D P K(I J)+H M \times 1 D R+R D D P R(I P J)]\}$

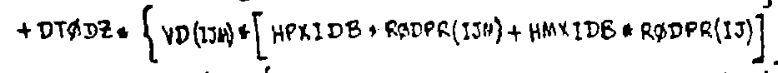

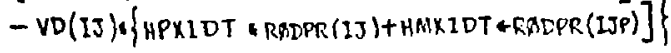

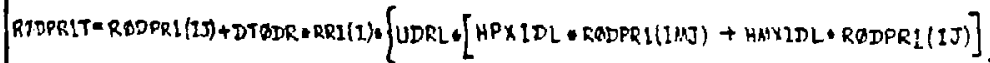
$-U D R R=[H P X I D R=R D D P R I(I J)+H M X I D R+R 3 D P R L(L P J)]\}$

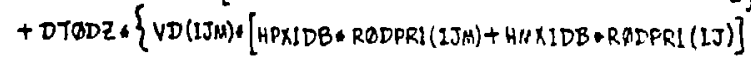
$-\operatorname{Vr}(1 \mathrm{~J}) \cdot[$ [HPXIDT+ RDDPRI (IJ) + HMXIDT* RTIPPRI (IJP) $]\}$

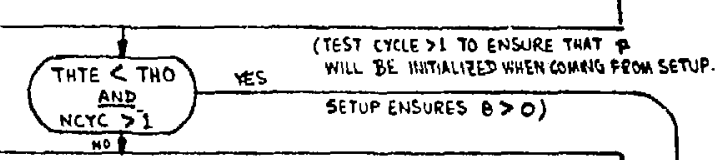

$R$ QVPR2 $=R$ ROVPR(IJ) - RळVPRI(1J)

$A(1 J)=\operatorname{SIEV}(I J)+[R O V P R I(1 J)+B V I G M 11+R Q V P R 2+B Y 2 G M 12]$

\{THTE\&[ROVPR1(IJ) \&BV1 + ROVPRZ +BV2]\}

$V E L=25 \cdot[U U(1 J) \cdots 2+U V(I M J) \cdot \cdot 2+V V(I T)$

GAMTE $=G G M 11 \cdot \operatorname{RQVPRL}(I J)+R R+G G M 12 \cdot[1 .-\operatorname{RQVPPRI}(2 J)+R R]$

GIROM = GAMTE : SIEV(IJ) "ROVPR (IJ) + SQMO

THTESQ = THTEN THTE

$V E L=V E L+P(I J) \cdot T H T E=R R$

RMSQ $=\{V E L+T H T E S Q+[R D V P R(2 J)+R O D P R(2 J)] / G I R Q M\} *+2$

(F) OP LOCAL

(节)

$F(13)=1 . /(1 .+10 .+8 M S Q)$

$P(I J)=F(I J)+P(I J)+[1,-F(I J)] * A(I J) \cdot \operatorname{RQVPR}(I J)$

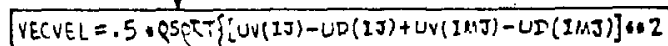
THTERM $=(1,-T H T E) /$ THTESQ
TLIJ

$\mathbb{R}_{(\text {real }}$

TTERM. $(N U N 3+R$

USE DIAO IN K. IF $2 \theta$

USED, IT MAY $=0$,

ThTKG)

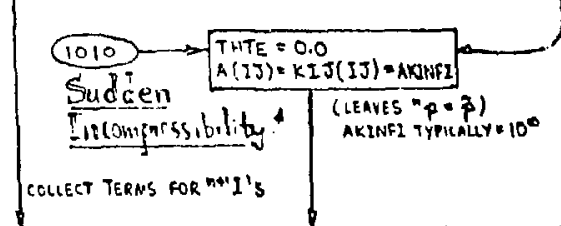

\section{$1020)$ SIEVC $=\operatorname{SIEV}(17)$}

SIEDC $=$ SIED (IT)

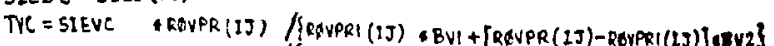

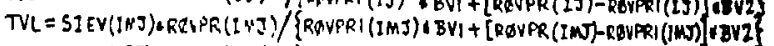

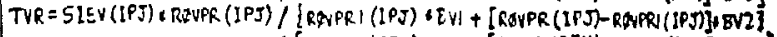

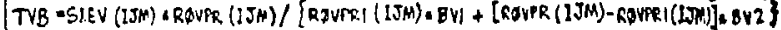

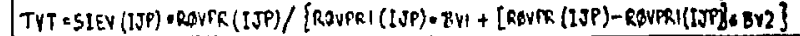




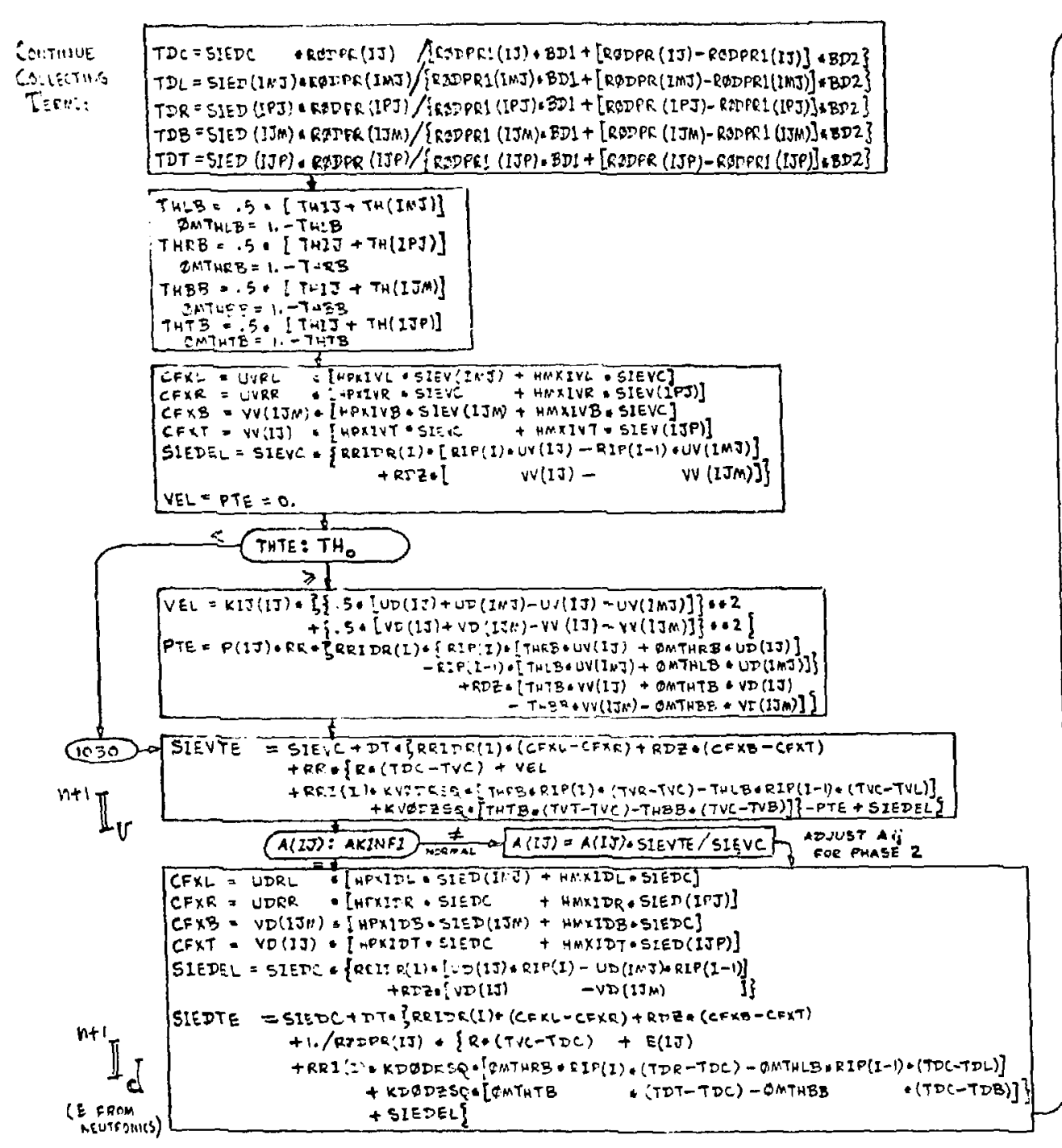

Boundorar Conditions...

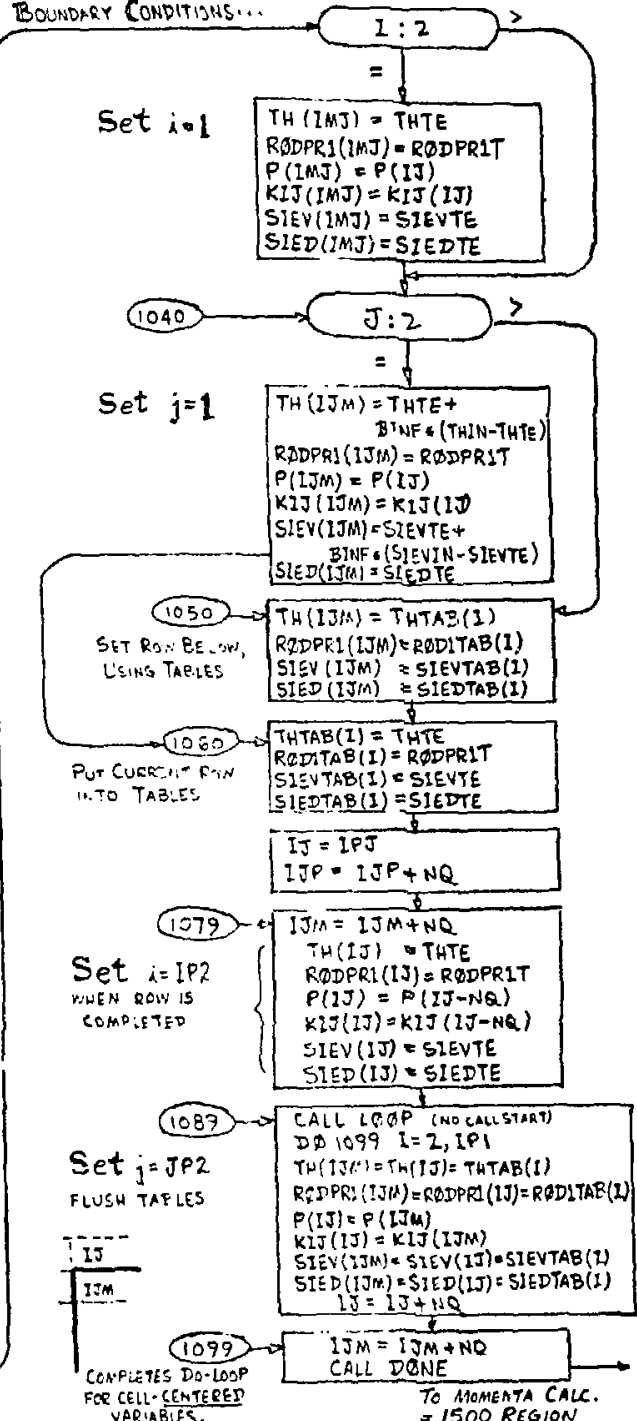




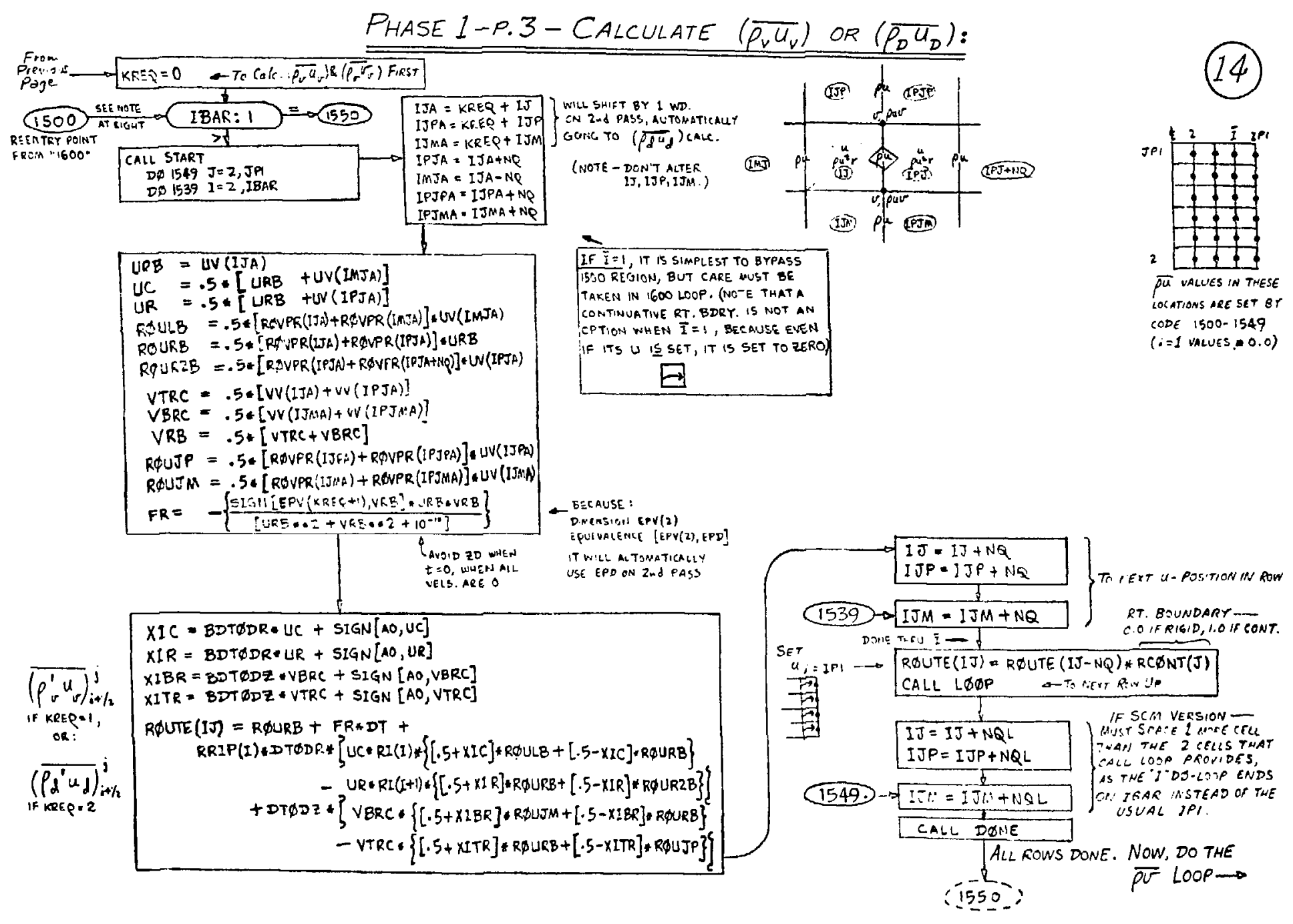




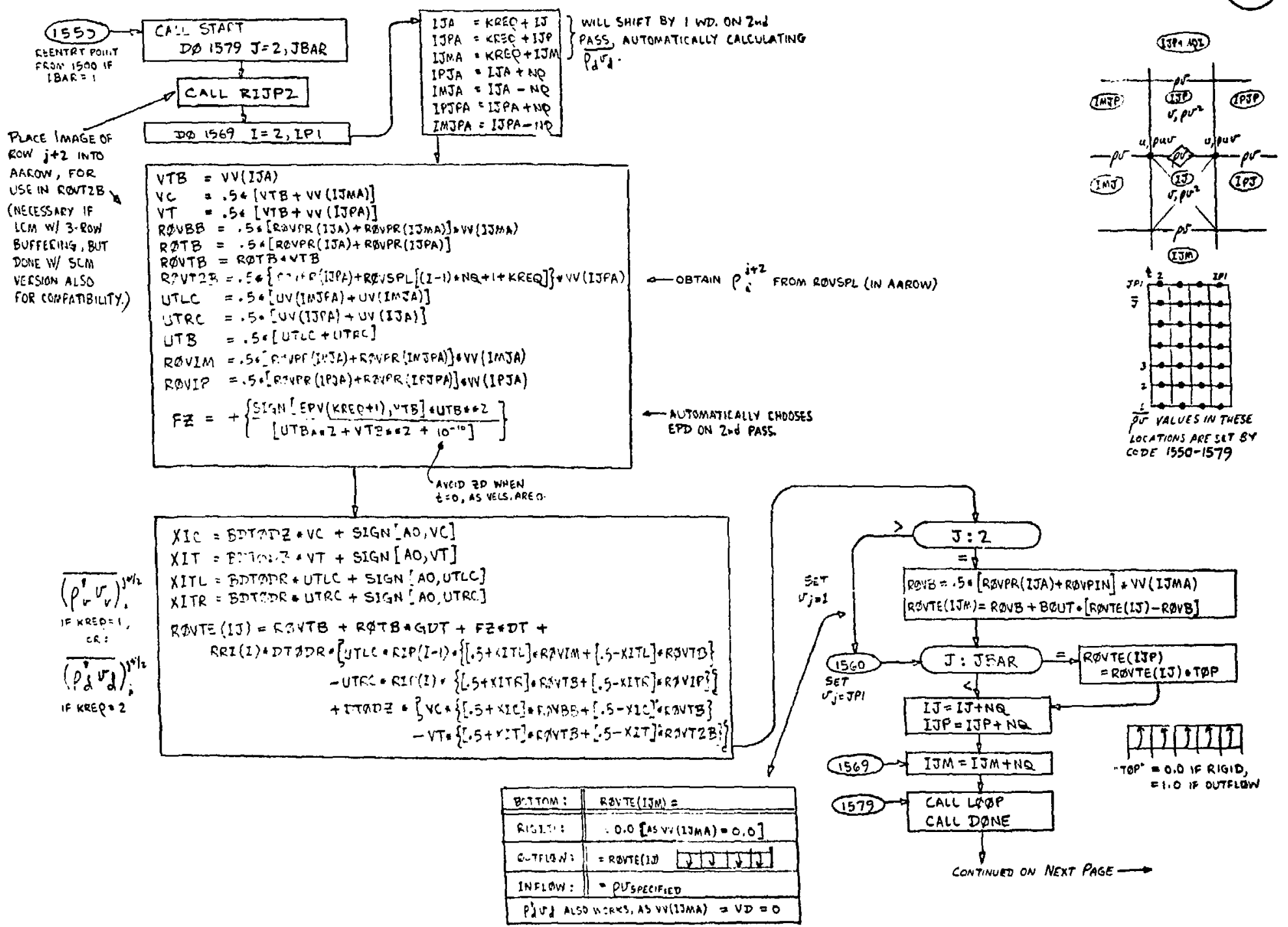


Phase 1-P.5-COMpletion of MOMENTUM CaLCULATION,

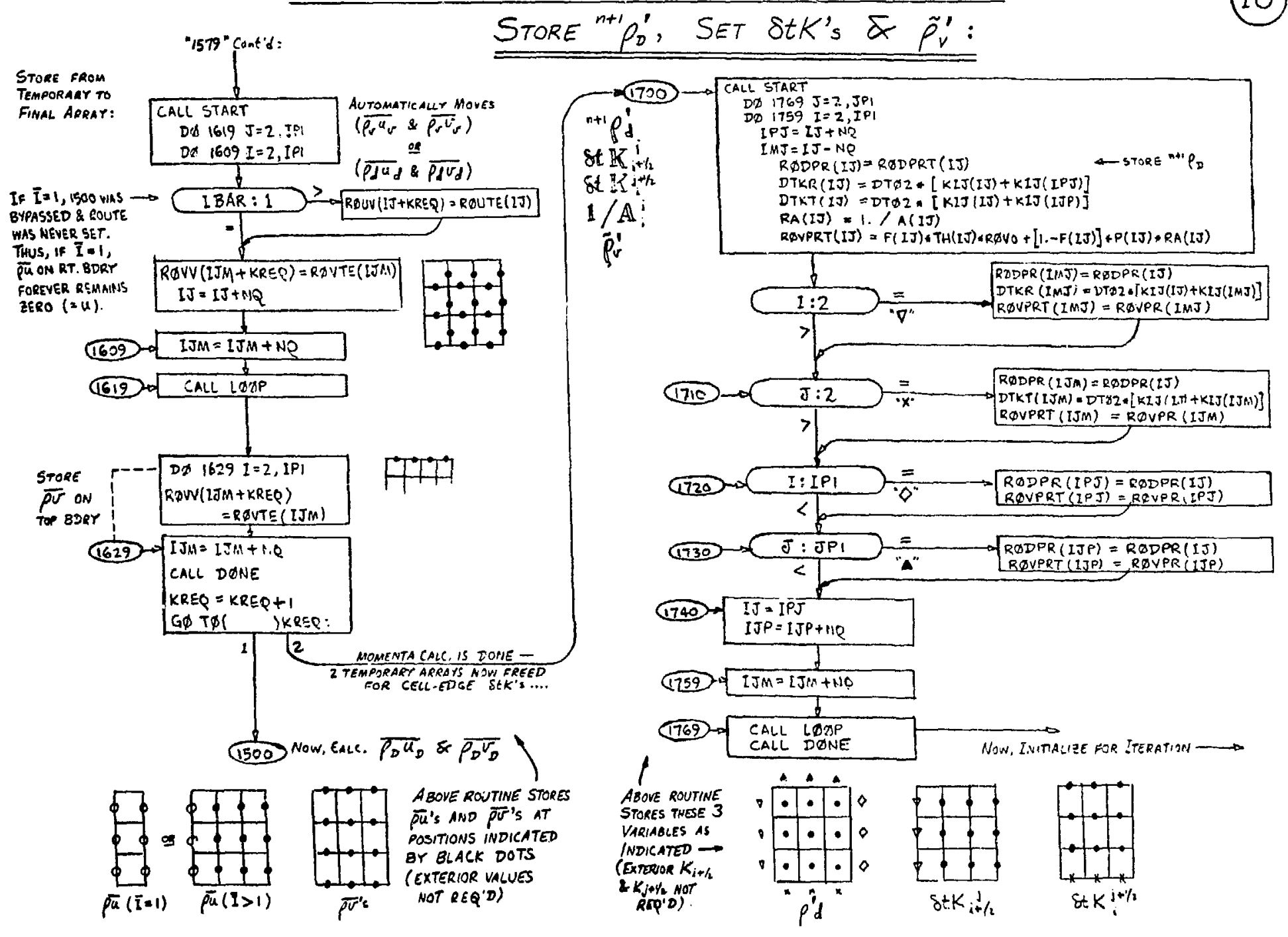


Phase 2-p.1-Initialize Tilde Velocities:

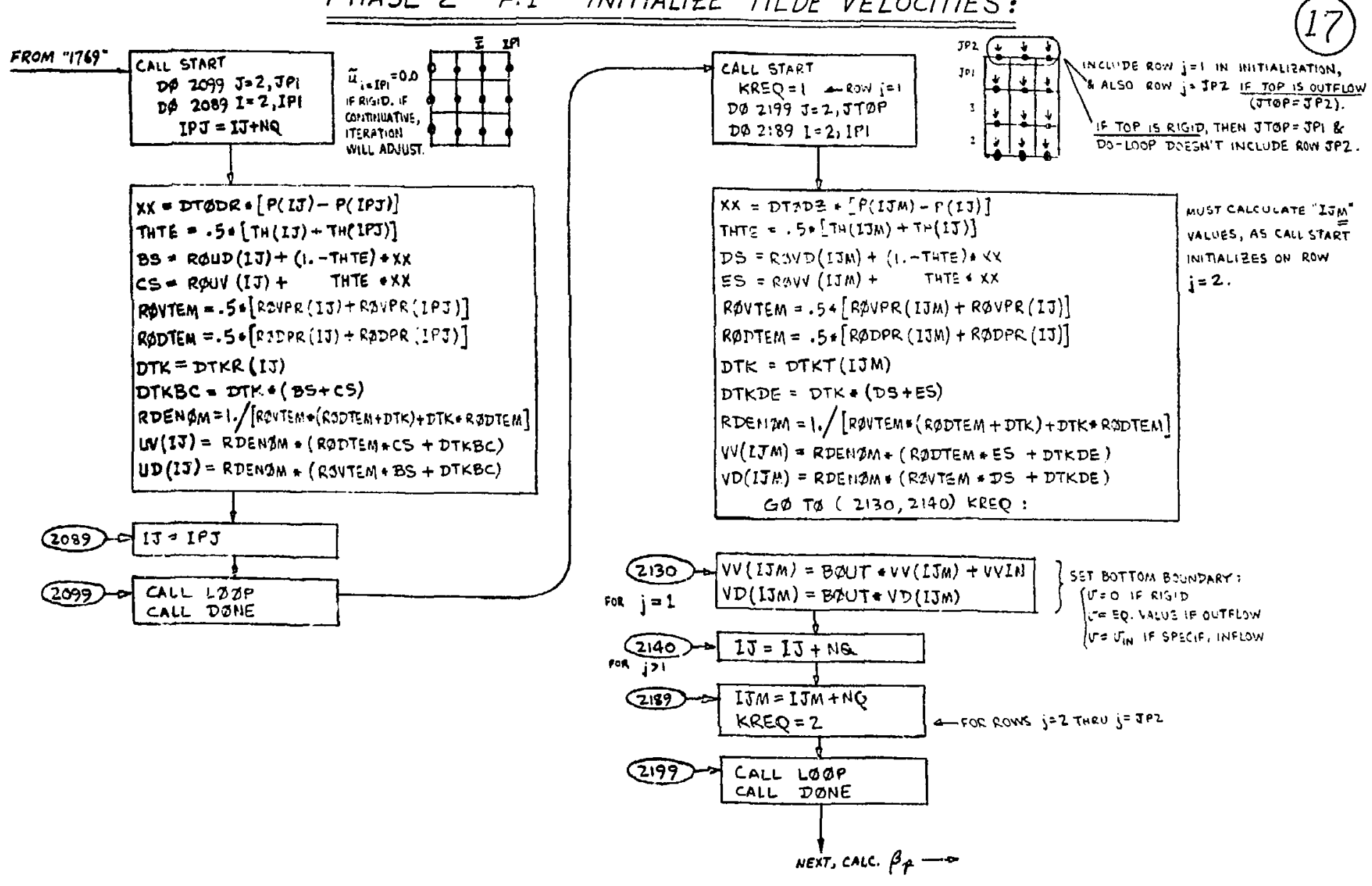


Phase 2-P.2-Calculate $\beta$ and Convergence:

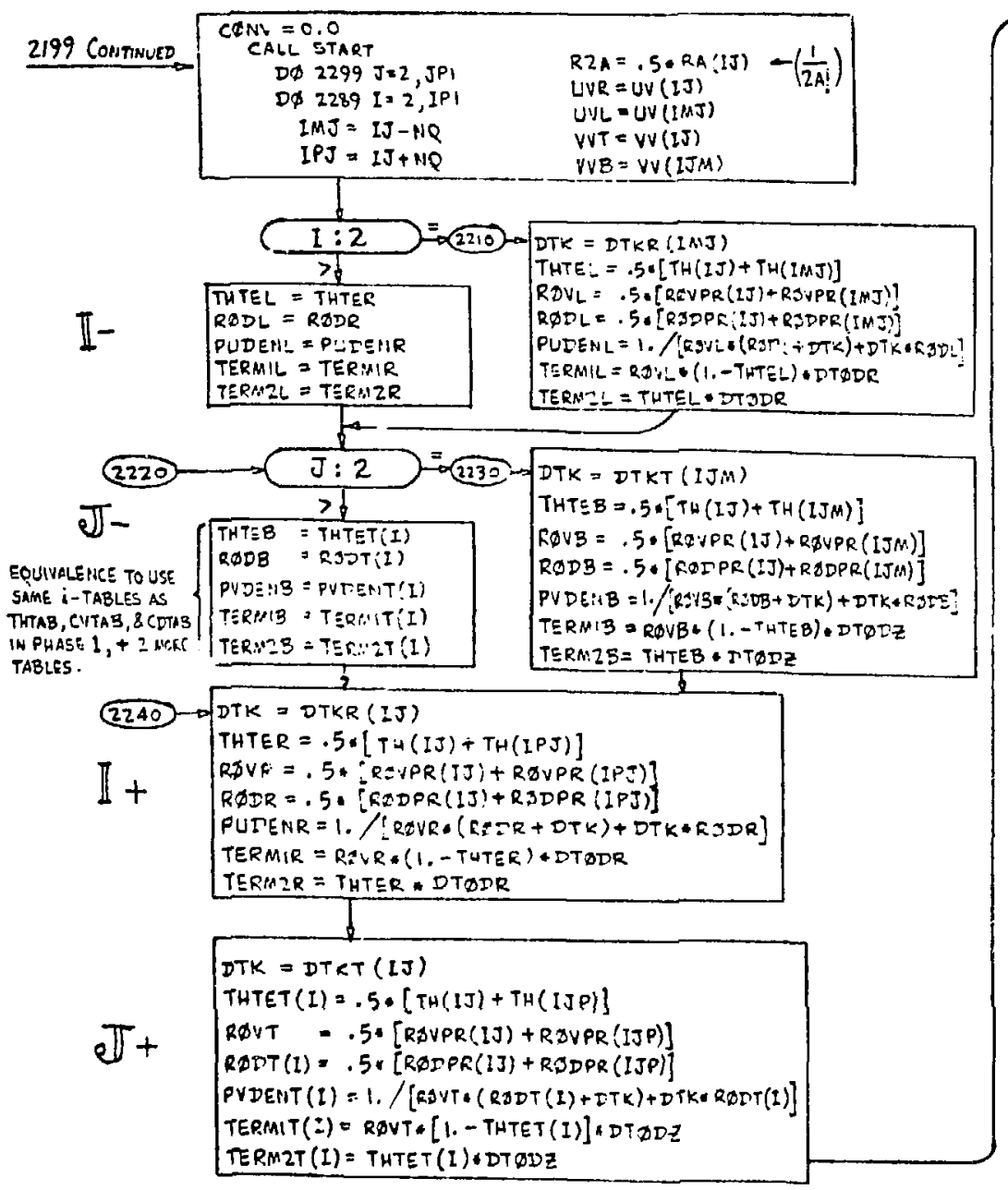

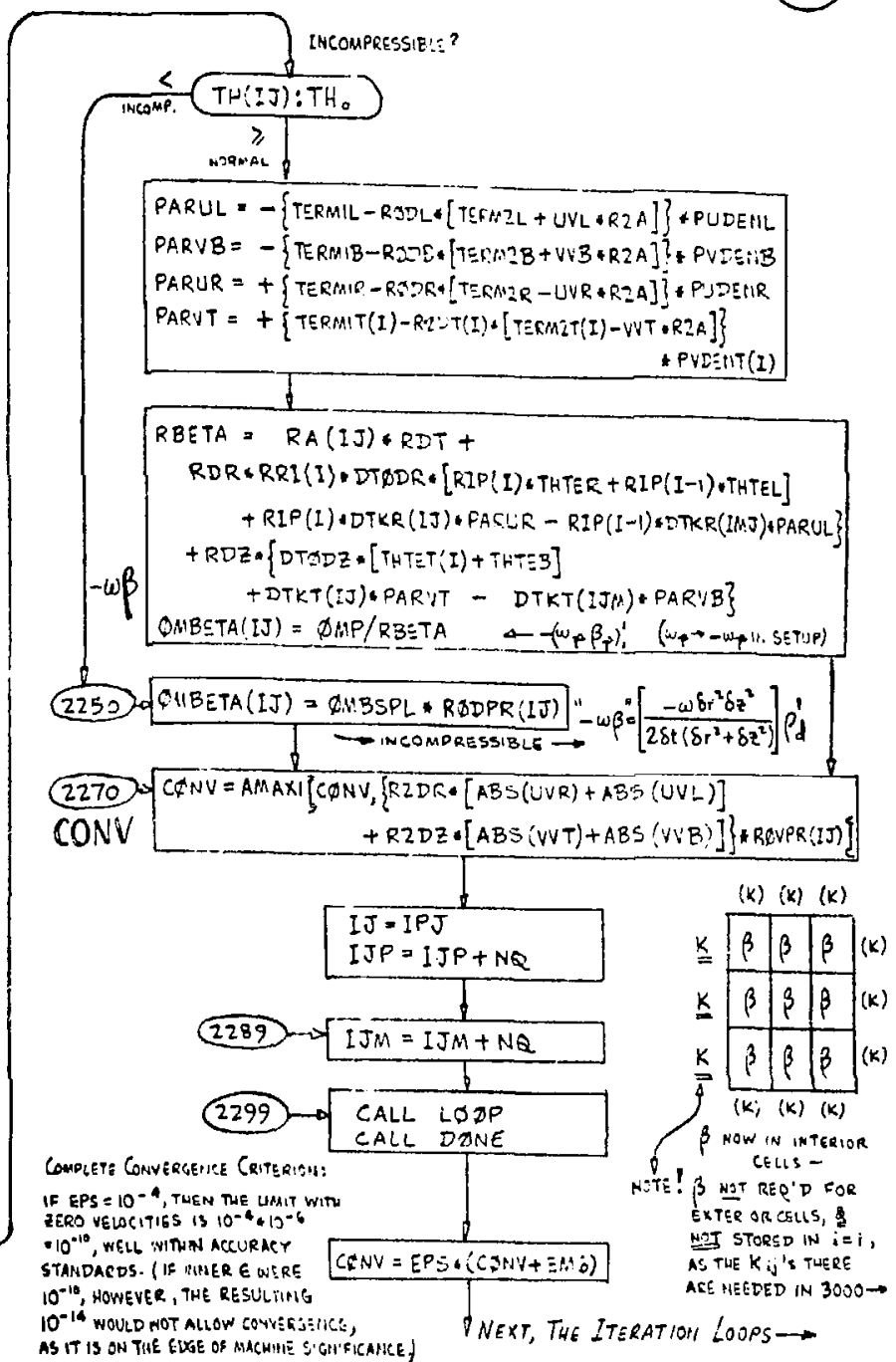




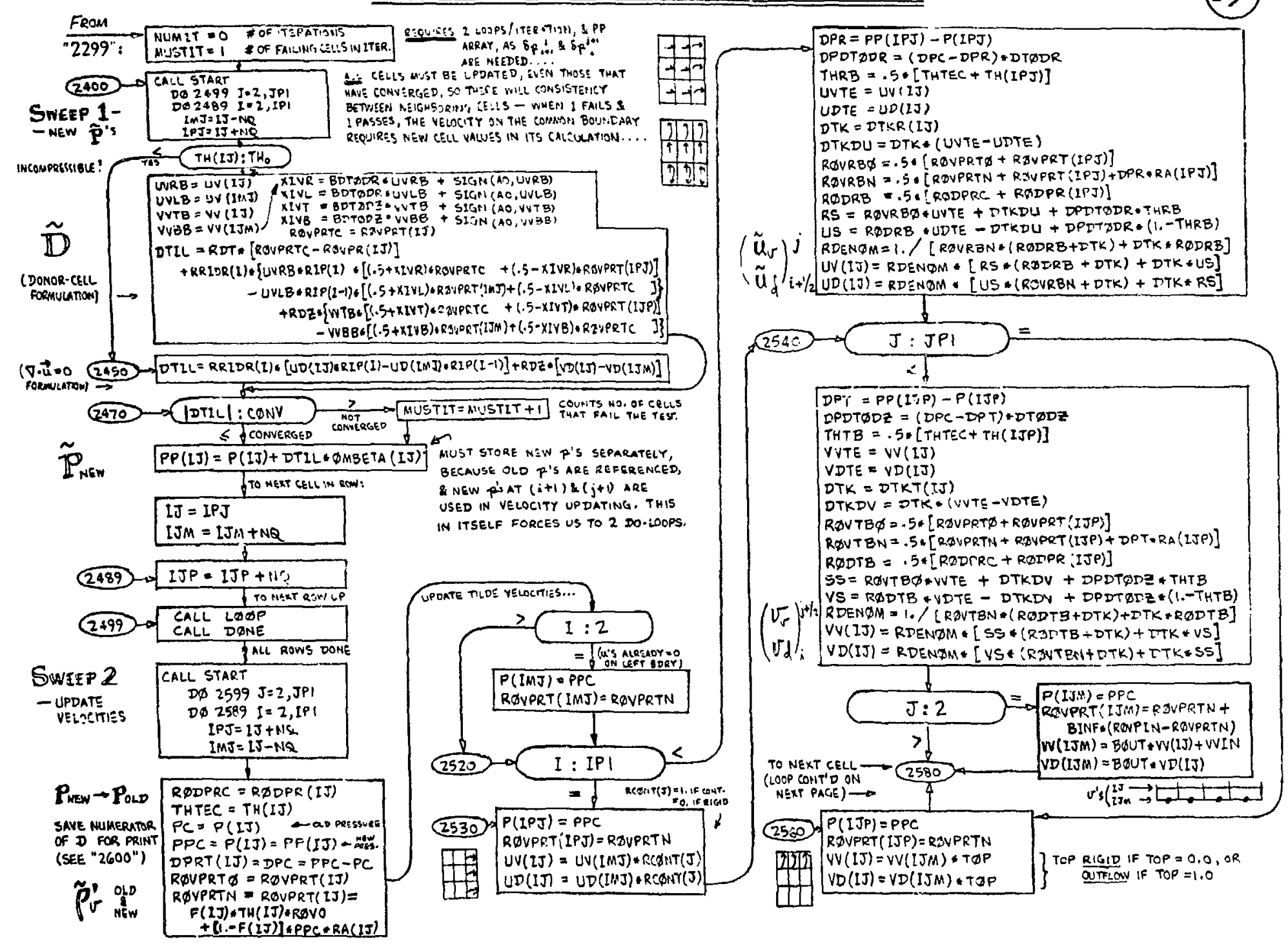




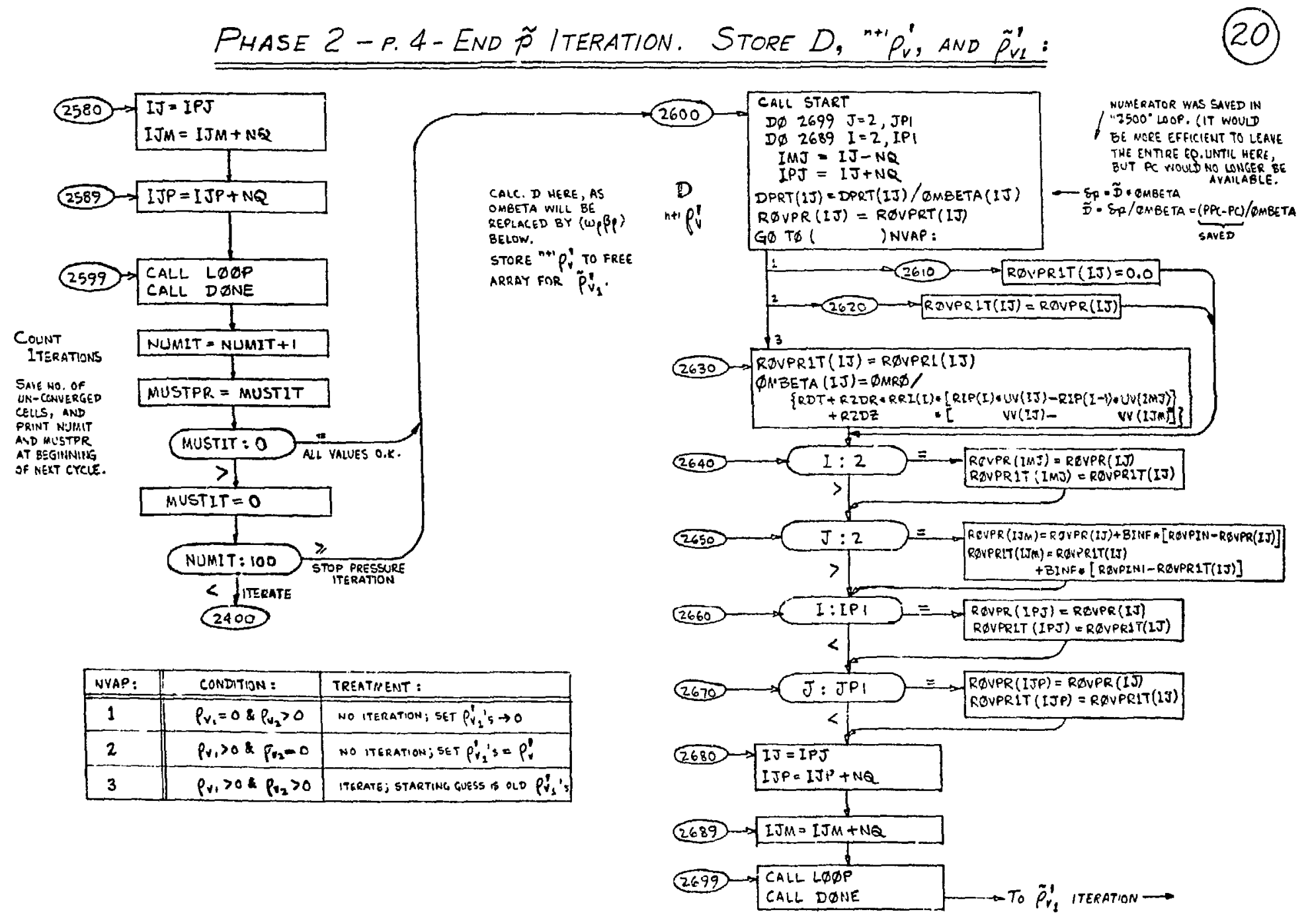




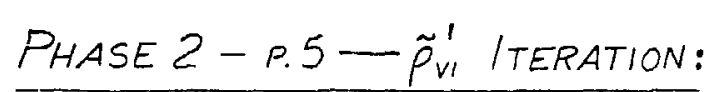

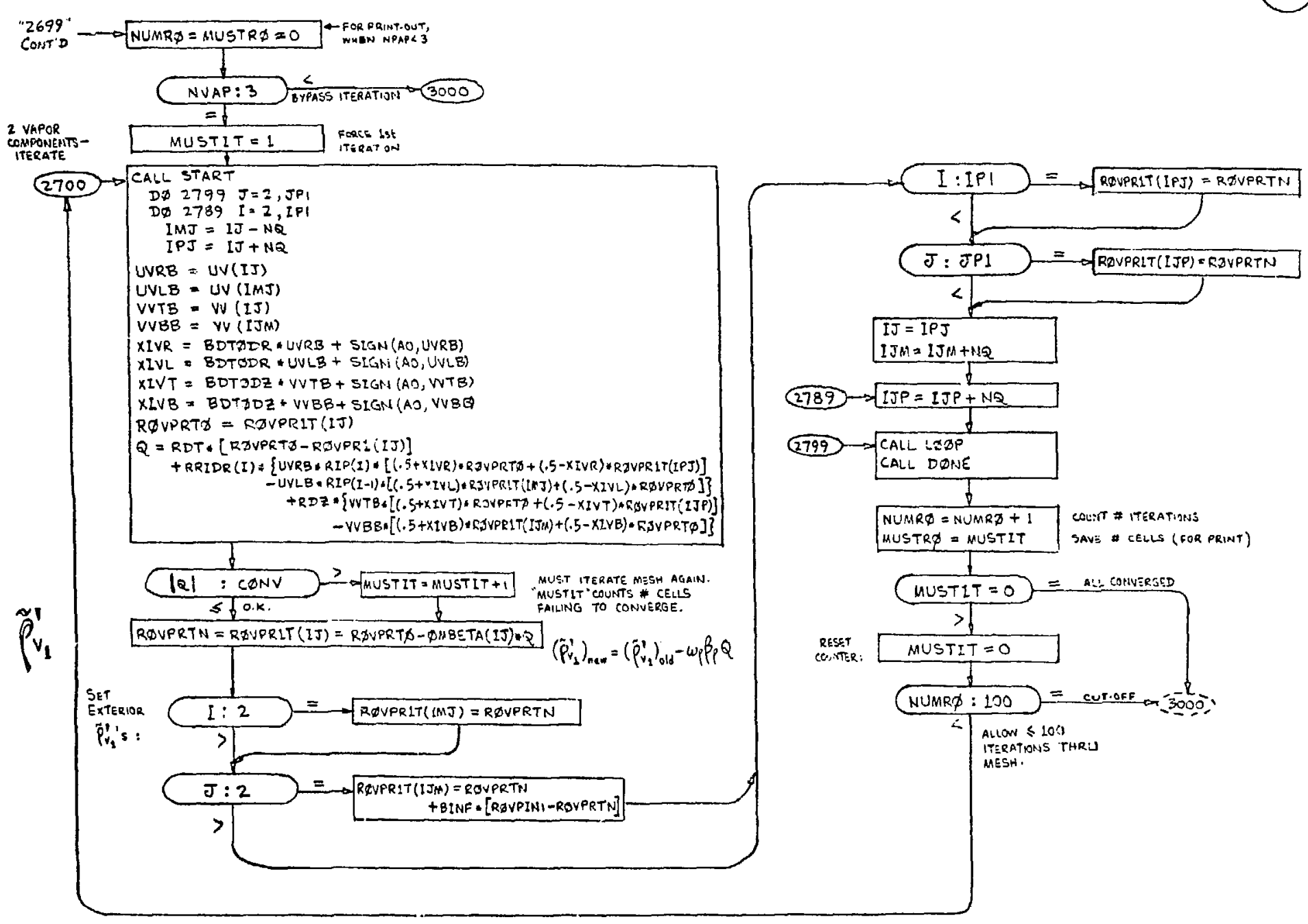




$$
\text { Phase 2-P.6-StORE K, A, and }{ }^{n+1} \rho_{V I}^{\prime}:
$$

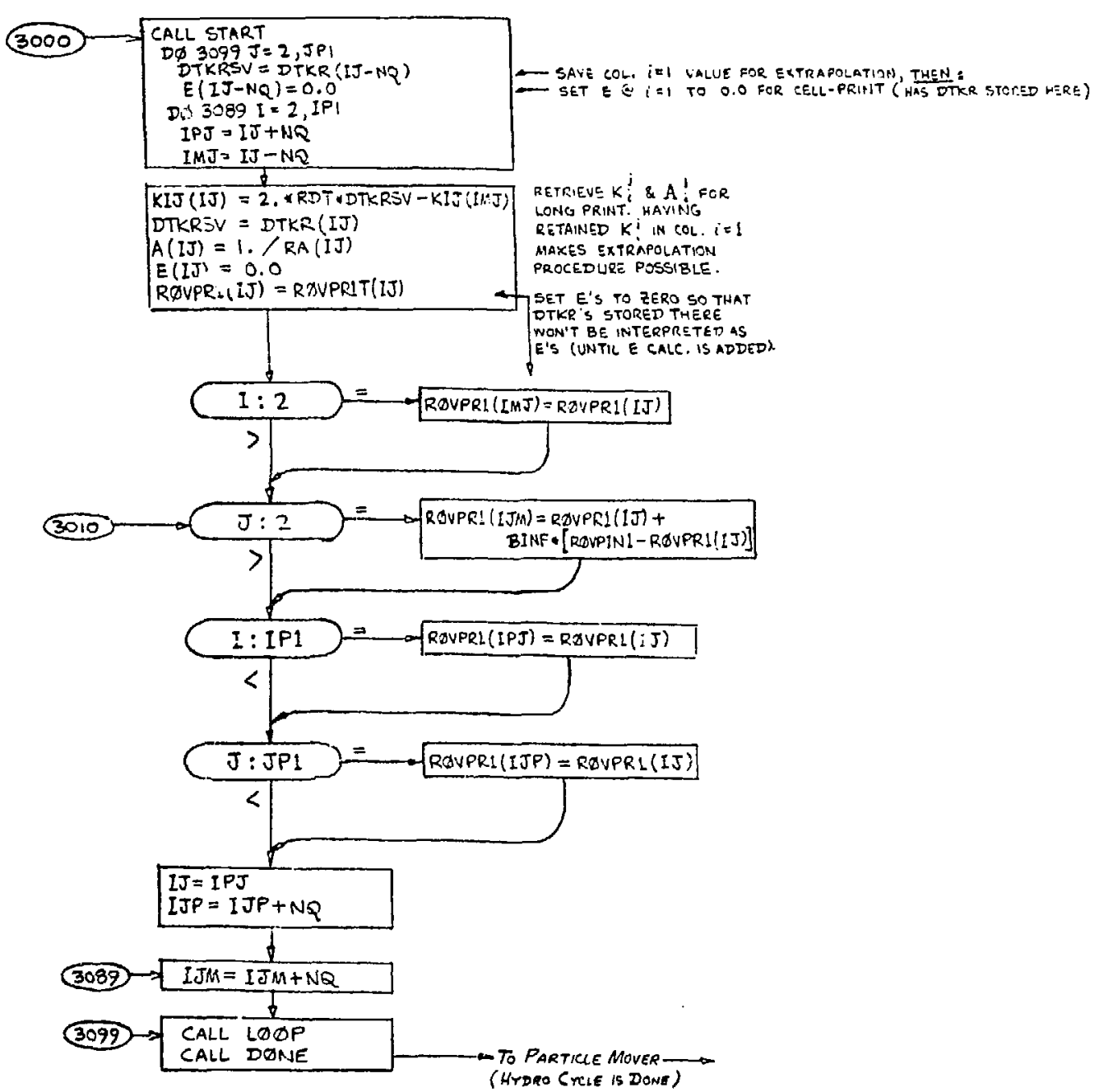


Particle Mover:

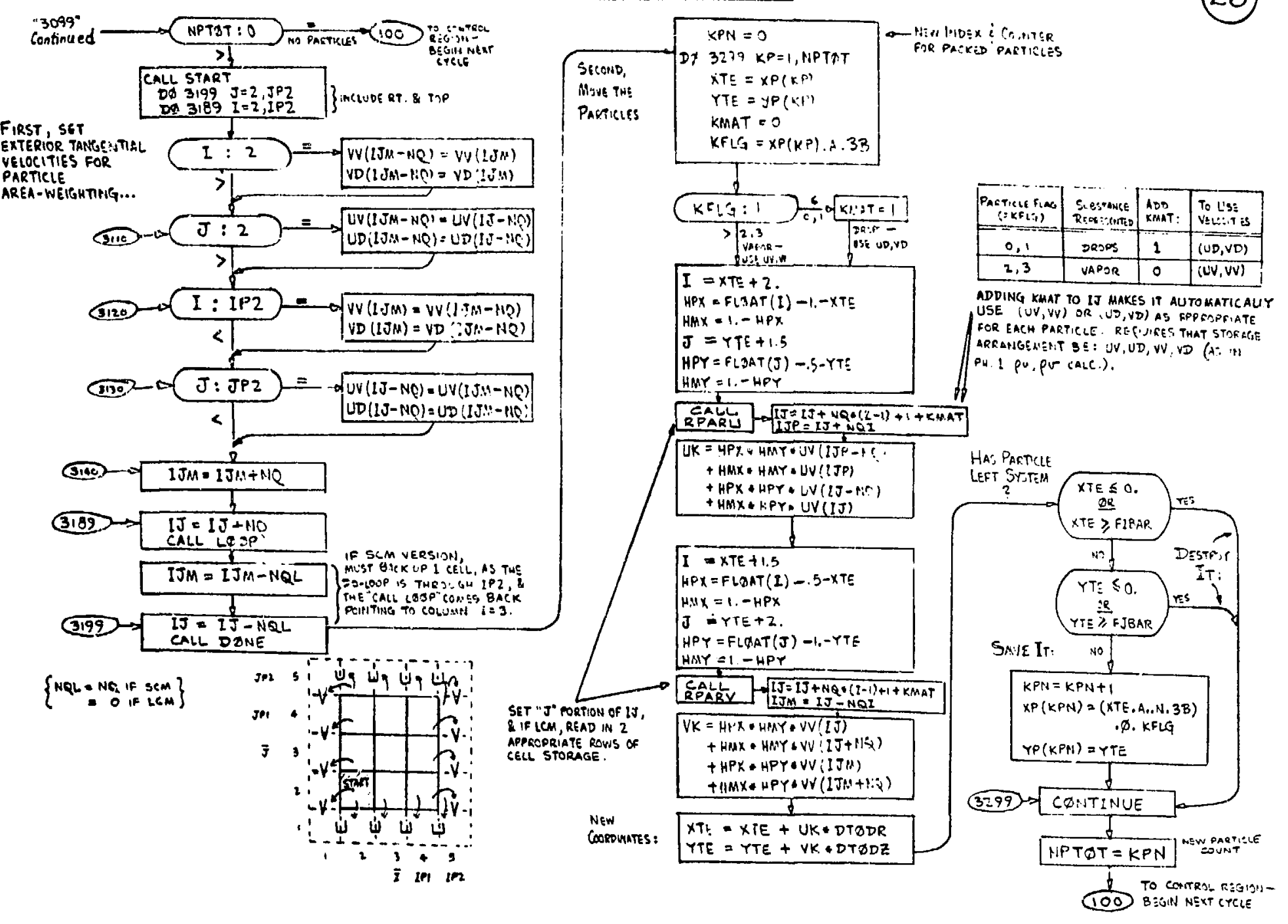


APPENDIX B

FORTRAN IV INDEX LISTING OF THE KACHINA PROGRAM

(June 19, 1974 Status)

LASL identification: LP-0335 
IHOEX COMDII.ED ON OS/M1,74,

INOFX START TIME IS 2.629 SECONOS

00000000000000000000000000040000000000000000000040000000004000000000000000000004000000000000000000000000000000000000000

VARTAHLES GRE DESCRIGED AY TYPE

FOH AHHAYS TYPE IS PHECEOCO BY II

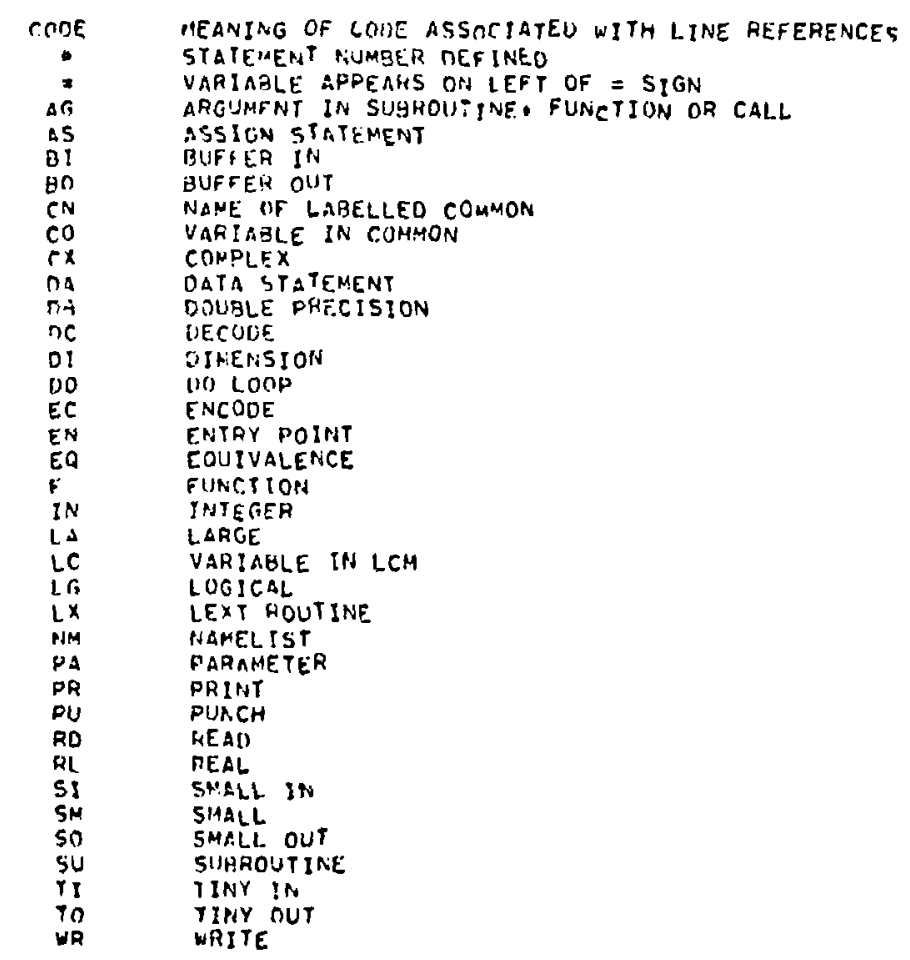


INDEX O1/00/75 RRUGHAM KACHINA IINP, OUT, FILM, FSET T=OUT, FSETIZ=FILM,FSETT,FSETB)

PROGAAM KACHIRA IINP, UUT, FILM,FSET $9=$ OUT, FSETI Z=F ILM, FSETT, FSETB COAMON /KSB' AAI (1), AANOW(908)

COMHON /KSC/ AA 11$\}$.AASC (26675), AKINFI,AO,BDTOOH,BRTOOZ,

I BOS BDZ, BIHF, BOUT, AVI, AVIGMII, AVZ, BVZGMI?.

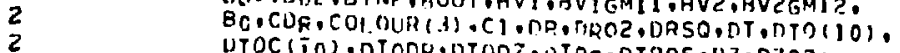

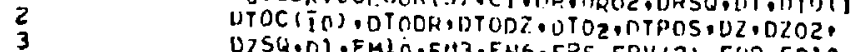

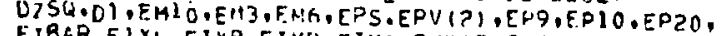

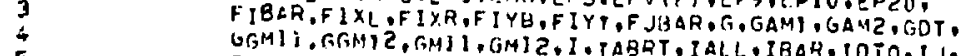

5 IJM, IJP,IPI,IPR,ISPR, IXL,IXR, IYB,IYT, JOJPAR, JNM, JPI,

$7 \quad J P 2$. JRIGIO,.JTOP,JX1,JX2,JX3.JZ,J3,KD,KOONASO.

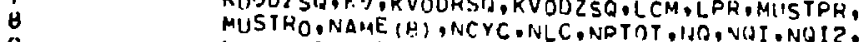

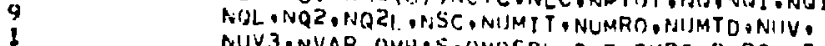

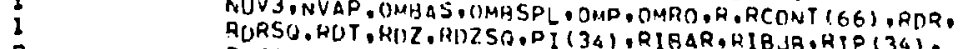

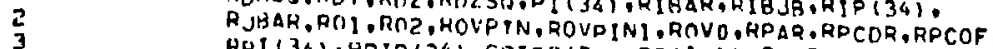

4 ARI 34), RRIP(34) , FRTDR (34),RROI, QROZ, RZOR, R2OZ,

STOMI TOL OT, THIN, THO, TLIMO OTOP. TOUT, TWFIN

-

4

1
2
3
4
3
6
7

KACHINA

KON

Kחn

KOM

$K_{K O M}^{K O M}$

$K \cap M$
$K O M$
$K O M$

KOM

KOM

KON

KON

KON

KnM

$K O P$

KOM
KOM

Kon

$\mathrm{kOM}$

(AASC(1). TH1) IAASC (?! .QOVPRI) , (AASC (3), AODPEI).

KON

FOURFAL

EOUPEAL (AASC ( ) , SIED), (AASC (B) ,P) . (AASC (9) ,KIJ,OMAETA), OUTTEOTKT)

(AASC (12) UIV, ROUV). (AASC (13), UD,ROUU),

(AASC (1) 4), VV,AOYV) , (AASC (15), VD,ROVD):

EOUIVALENCF

(AAROW (4), ROVSPL)

EEATVLENCE TEPVIL, EPO)

CAL KD,KDODASO,KDODLSOIKIJ JKVIKVOORSO,KVODZSO, NUV, NUUV

CALL DATE. I TOL)

$10 \quad$ HO $=19$

RE $=19$

10 READ IOO, IHAR,JEAF, DR, OZ OAO,HO,HOVO,NIV, CDR,RPAR IABRT $=0$

20 CALL OVERLAY 40.30 .20

20 IF (IABRT ONE TLKACHFIL,I,0,0)

30 IF (IABRT.AIE.O) GU TO 10

30 CALL OVERLAY (7LKACHFIL,2.000)

40 CALI EMPTY

IOII FORHAT $1214.8 F 9.31$ 


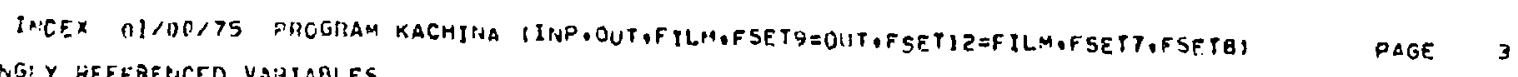

\begin{tabular}{|c|c|c|c|c|c|c|c|c|c|c|c|c|c|c|c|c|c|c|c|c|}
\hline A & -8 & $4 E 0$ & OIOD2 & $-A$ & 300 & $G$ & & & & & & & & & & & & & & \\
\hline AA & (1) & 360 & 0702 & $-n$ & 300 & GAMI $_{2}$ & $-\infty$ & $\begin{array}{l}3(0) \\
3(0)\end{array}$ & $\begin{array}{l}\text { JTho } \\
j \times 1\end{array}$ & -1 & $3 \mathrm{Cn}$ & OMBAS & $-k$ & $3 \mathrm{CO}$ & ROIU & $-R$ & $40_{0}^{\circ}$ & $T_{H}$ & $-A$ & \\
\hline AAI & 117 & $2 \mathrm{CO}$ & DIPAS & -2 & 300 & GAMZ & -8 & $3 \mathrm{CO}$ & $\begin{array}{l}J \times 1 \\
j \times 2\end{array}$ & $\begin{array}{l}-1 \\
-1\end{array}$ & $\begin{array}{l}3 \mathrm{CO} \\
3 \mathrm{CO}\end{array}$ & OMEETA & $\begin{array}{l}-R \\
-R\end{array}$ & $4 E O$ & ROVD & $-R$ & 460 & THIN & $-R$ & 360 \\
\hline AKINFI & $\begin{array}{l}-2 \\
-2\end{array}$ & $\begin{array}{l}3 c 0 \\
3 c 0\end{array}$ & 0202 & -2 & 300 & iut & $-R$ & $3 \mathrm{co}$ & $j \times 3$ & $-I$ & $3<0$ & $\begin{array}{l}\text { OMBSPL } \\
\text { OME }\end{array}$ & $\begin{array}{l}-8 \\
-k\end{array}$ & $\begin{array}{l}3 \mathrm{Cn} \\
3 \mathrm{CO}\end{array}$ & $\begin{array}{l}\text { ROVPIN } \\
\text { ROVPINI }\end{array}$ & $\begin{array}{l}-P \\
-P\end{array}$ & $3 \mathrm{CO}$ & THO & $-R$ & \\
\hline BDTODZ & $\begin{array}{l}-A \\
-R\end{array}$ & $3 \mathrm{CO}$ & $n^{n z S \theta}$ & $\begin{array}{l}-H \\
-R\end{array}$ & 300 & GE TQ & $\therefore$ & ASU & $J 2$ & -1 & $3 C 0$ & OMRO & $-R$ & $3 \mathrm{CO}$ & RกVPR & $\rightarrow A$ & $\begin{array}{l}3 C 0 \\
\text { GEO }\end{array}$ & $\begin{array}{l}\text { TLIND } \\
\text { TOD }\end{array}$ & $\begin{array}{l}-8 \\
-8 \\
-8\end{array}$ & \\
\hline 501 & $-a$ & 3 ro & E BAF TY & $\because$ & $\begin{array}{r}4 E 0 \\
14511\end{array}$ & $\begin{array}{l}6 G M_{11} \\
\left.66 M_{1}\right]\end{array}$ & $\begin{array}{l}-R \\
-R\end{array}$ & $\begin{array}{l}360 \\
300\end{array}$ & $\begin{array}{l}33 \\
K A C H E H A\end{array}$ & $-I$ & $3 \mathrm{Co}$ & $\mathbf{P}$ & $-R$ & $\triangle F 0$ & ROVPRT & $-R$ & SEA & $\begin{array}{l}\text { TOU } \\
\text { TOU }\end{array}$ & $\begin{array}{l}-R \\
-R\end{array}$ & \\
\hline BOD? & $-R$ & $3 \mathrm{Cn}$ & EIMIO & -18 & $3 e n$ & GM?! & $a$ & $\begin{array}{l}3(0) \\
3 C^{\prime \prime}\end{array}$ & $\begin{array}{l}\text { KACHINA } \\
K S B\end{array}$ & - & ISI & PP & $-R$ & CEO & ROVPRI & $-R$ & AEB & THF IN & $-R$ & $\begin{array}{l}360 \\
360\end{array}$ \\
\hline BINF & $-R$ & 300 & EMJ & $-R$ & 300 & $(i M)_{2}$ & $-A$ & 3 r. & $\begin{array}{l}\mathrm{KSB} \\
\mathrm{KSC}\end{array}$ & - & $\begin{array}{l}2 \mathrm{CN} \\
3 \mathrm{CN}\end{array}$ & $R$ & $\begin{array}{l}-8 \\
-R\end{array}$ & 360 & ROVPRIT & $-A$ & LEO & 12040 & $\rightarrow R$ & \\
\hline DOUT & -8 & $3 \mathrm{Cn}$ & $\begin{array}{l}E M 6 \\
E P D\end{array}$ & $\begin{array}{l}-8 \\
-R\end{array}$ & 300 & & -1 & 360 & LCM & $=I$ & $\begin{array}{l}3 C N \\
3 C O\end{array}$ & $\begin{array}{l}\text { RA } \\
\text { RCONT }\end{array}$ & & $\begin{array}{l}4 E D \\
3 C O\end{array}$ & ROVSPL & $-A$ & 5EO & in & $-R$ & $A E Q$ \\
\hline $\begin{array}{l}\text { BVI } \\
\text { BVigm, }\end{array}$ & $\begin{array}{l}-2 \\
-a\end{array}$ & $\begin{array}{l}3 \mathrm{CO} \\
3 \mathrm{Cn}\end{array}$ & $\begin{array}{l}E P() \\
\text { EPS }\end{array}$ & $\begin{array}{l}-R \\
-R\end{array}$ & GE? & IALI. & -1 & $3 r 0$ & {$\left[P_{R}\right.$} & $-I$ & $3 \mathrm{cn}$ & RER & $\begin{array}{l}-R \\
11\end{array}$ & $\begin{array}{l}3 \mathrm{CO} \\
3 \mathrm{Cn}\end{array}$ & $\begin{array}{l}\text { ROVTE } \\
\text { HOVY }\end{array}$ & $\begin{array}{l}-9 \\
-A\end{array}$ & AED & UV & $-R$ & $\triangle E B$ \\
\hline Gy? & -8 & 300 & EPIo & $\begin{array}{l}-R \\
-R\end{array}$ & $\begin{array}{l}3 \in 0 \\
3<0\end{array}$ & $\begin{array}{l}1010 \\
15\end{array}$ & $\begin{array}{l}-1 \\
-1 \\
-1\end{array}$ & $\begin{array}{l}3 \mathrm{Co} \\
3 \mathrm{CO}\end{array}$ & MUSTPR & - & $3 c n$ & RORSO & $-R$ & 360 & RO) & $-Q$ & $\begin{array}{l}4 E 0 \\
3 C 0\end{array}$ & yo & $-A$ & \\
\hline $8025 \times 12$ & -8 & 360 & EP?O & $-A$ & 3en & i Jit & $\begin{array}{l}-1 \\
-1\end{array}$ & $\begin{array}{l}360 \\
3<0\end{array}$ & $\begin{array}{l}\text { HUSTRO } \\
\text { NAME }\end{array}$ & $=$ & $3 \mathrm{CO}$ & ROT & $-R$ & $3 \mathrm{cn}$ & RO? & $-R$ & $3<0$ & $\forall O_{L R}$ & IRR & 3 \\
\hline SLOCKI & $\therefore$ & insul & $E^{P 9}$ & $-A$ & $3<0$ & $\mathrm{JP}$ & $-i$ & 300 & $\begin{array}{l}\text { NAUE } \\
\text { NT,YC }\end{array}$ & 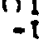 & $\begin{array}{l}3 \mathrm{Cn} \\
3 \mathrm{CO}\end{array}$ & $\begin{array}{l}\text { ROZ } \\
\text { ROZSO }\end{array}$ & $\begin{array}{l}-R \\
-R\end{array}$ & $\begin{array}{l}3<0 \\
7<0\end{array}$ & RPCDR & -9 & $3 C 0$ & vv & $-A$ & 36 \\
\hline $\begin{array}{l}\text { COLOUR } \\
\text { co }\end{array}$ & $\begin{array}{l}-5 \\
n\end{array}$ & $\begin{array}{l}3 \mathrm{CO} \\
4 \mathrm{5}\end{array}$ & $\begin{array}{l}\text { F } \\
\text { FIBAR }\end{array}$ & $\begin{array}{l}-k \\
-N\end{array}$ & $\begin{array}{l}\text { AES } \\
3 P 0\end{array}$ & $\begin{array}{l}\text { INP } \\
I_{\mid} P_{I}\end{array}$ & $=1$ & $\begin{array}{l}1 A G \\
3 C 0\end{array}$ & NLC & $-i$ & 300 & REAO & $\because$ & $\begin{array}{l}720 \\
125\end{array}$ & $\begin{array}{l}\text { RPCOF } \\
\text { RA I }\end{array}$ & iी & $\begin{array}{l}360 \\
300\end{array}$ & $\begin{array}{l}V v I N \\
x \operatorname{IN}\end{array}$ & $\begin{array}{l}-A \\
-A\end{array}$ & \\
\hline DATE? & - & 9 sis & $F I X L$ & -8 & 3 Co & 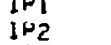 & -1 & $\begin{array}{l}360 \\
300\end{array}$ & NPTOT & -1 & $3 \mathrm{CO}$ & AEAL & - & is & RRIOR & in & 300 & $\begin{array}{l}x \operatorname{CONV} \\
x_{L}\end{array}$ & $-R$ & 30 \\
\hline OPRT & $-R$ & LER & $F I \times H$ & -9 & $3 \mathrm{co}$ & ISPF & $-I^{2}$ & 300 & NoI & $=$ & $\begin{array}{l}3 \mathrm{CO} \\
3 \mathrm{CO}\end{array}$ & RI & $11 R$ & $3 \mathrm{CO}$ & RAID & IIR & $3 e n$ & $x^{2}$ & IIR & 30 \\
\hline [00? & $-R$ & $3 \mathrm{cu}$ & Irg & $-R$ & 300 & I $\times L$ & $-I$ & 300 & $\mathrm{NOL}$ & - & $\begin{array}{l}3 \mathrm{CO} \\
3 \mathrm{CO}\end{array}$ & $\begin{array}{l}\text { PIBAR } \\
\text { RIAJR }\end{array}$ & $\begin{array}{l}-9 \\
-8\end{array}$ & $3 \mathrm{CO}$ & RRก 1 & $-A$ & $3 \mathrm{co}$ & $X R$ & $-R$ & \\
\hline $\begin{array}{l}\text { nRSO } \\
\text { nRT }\end{array}$ & -8 & $3 \mathrm{Co}$ & FIYT & $-A$ & 360 & $I \times K$ & $-i$ & 300 & vis? & -1 & 360 & $\begin{array}{l}\text { RIAJA } \\
\text { Rip }\end{array}$ & $U^{-A}$ & $3 C 0$ & RRO? & $-A$ & $3 \mathrm{co}$ & & $-\mathbf{R}$ & \\
\hline $\begin{array}{l}\text { DT } \\
\text { DTKA }\end{array}$ & $\begin{array}{l}-8 \\
-8 \\
-8\end{array}$ & $\begin{array}{l}3 \mathrm{Cn} \\
\text { GED }\end{array}$ & F.JGAR & $-R$ & 360 & IYB & $-I$ & $3 r .0$ & vo? & 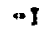 & 300 & RJHAR & $-a$ & $\begin{array}{l}360 \\
360\end{array}$ & $\begin{array}{l}\text { R20R } \\
\text { R2012 }\end{array}$ & $\begin{array}{c}-8 \\
-R\end{array}$ & $3 \mathrm{CO}$ & YCONV & $-R$ & \\
\hline DTKT & -8 & SEN & $\begin{array}{l}\text { FORMAT } \\
\text { FSETIZ }\end{array}$ & -8 & $20 F$ & $\int_{j}^{j}$ & $\begin{array}{ll}-1 \\
-1\end{array}$ & 300 & NSC & -1 & $3 \mathrm{CD}$ & ROUPR & $-A$ & 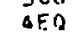 & $\begin{array}{l}\text { Ratiz } \\
\text { SIED }\end{array}$ & $\begin{array}{l}-R \\
-R\end{array}$ & $\begin{array}{l}3 \mathrm{Cn} \\
4 \mathrm{EO}\end{array}$ & $\begin{array}{l}Y P \\
Y T\end{array}$ & $\begin{array}{l}\| R \\
-R\end{array}$ & $3 \mathrm{c}$ \\
\hline DTO & (1) $\mathrm{P}$ & 360 & FSETT & -4 & $\begin{array}{l}\text { IAG } \\
\text { IAG }\end{array}$ & $\begin{array}{l}J^{\prime} \\
J N_{1}\end{array}$ & -1 & $\begin{array}{l}360 \\
300\end{array}$ & NLUTT & - & 300 & RDIIPRT & $-P$ & पED & SIEV & $-R$ & $4 E 0$ & 22 & $-R$ & $3 \mathrm{C}$ \\
\hline DTCE & (I) $R$ & $3 \mathrm{CO}$ & FSETB & $-R$ & IAG & JH? & $-i$ & $\begin{array}{l}360 \\
300\end{array}$ & $\begin{array}{l}\text { NUMRT } \\
\text { HAUTO }\end{array}$ & $=$ & $\begin{array}{l}3 \mathrm{CO} \\
3 \mathrm{CO}\end{array}$ & ROIJPR I & $\begin{array}{l}-8 \\
-8\end{array}$ & LEO & SIEVIN & $-R$ & 300 & & & \\
\hline & & $3 C 0$ & FSETG & $-A$ & IAG & JRIGIO & $-i$ & 300 & NVAP & & 360 & ROUTE & $\begin{array}{l}-a \\
-A \\
-A\end{array}$ & $\begin{array}{l}\triangle E O \\
4 E O\end{array}$ & Somo & $\begin{array}{l}-R \\
-R\end{array}$ & $\begin{array}{l}3 \mathrm{CO} \\
3 \mathrm{Co}\end{array}$ & & & \\
\hline
\end{tabular}

HLTJULYTREFFRENCFOI VAKIAALES

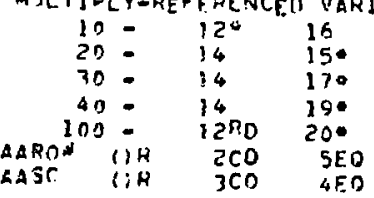

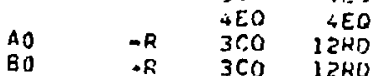

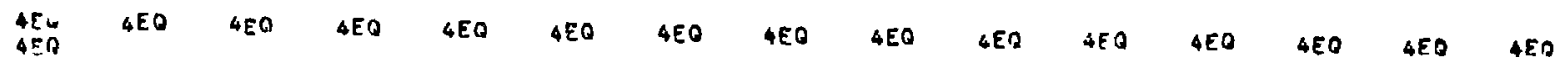

$\begin{array}{llll}C O H & \rightarrow R & 3 C O & 12 H O \\ C O H M O N & -R & 3 C O & 12 K 0\end{array}$

$\begin{array}{llll}\text { COHMON } & - & 2 F & 3 F \\ C 1 & -A & 3 C O & 10 A G\end{array}$

$\begin{array}{llll}D R & -A & 3 C n & 12 R D \\ O Z & -R & 3 C n & 1200\end{array}$

DI 1 - 3 CO

FPV UR उCO AEQ

EOLIVAL - $\quad$ GF $5 F$ GF

IAERT -I JCO IAG

IAAR -I JCO TJE 16

JBRH -1 3 $3(\mathrm{CO} 12 \mathrm{HB}$

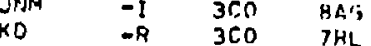

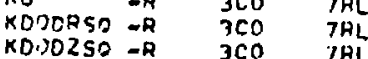


INDEX OI/DO/75 PHOGRAM KACHINA (INP.OUT, FILM,FSET9JOUT, FSETIZ EFILM,FSETT, FSETB)

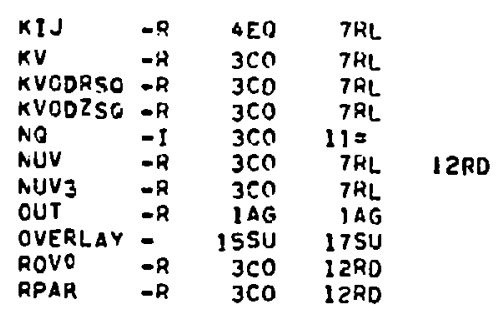


SUBROUTINE LDUP

COMMIN /KSB AAI II, AAROW (9BB)

KACHINA

, A

BOI , BDZ, BIFUF, GOUT, BVI, AVIGMII, BVZ, BVZGMIZ,

BO,CDR.COLOIIR (3),CI, OA, OROZ,URSO.DT,OTO(10), DZSO.DI.EMLO.EMJ.EMGIEPS.EPV (Z), EPQ,EPIO, EPZO,

KON

KחM

KOM FIBAF, FIXL, FIXH,FIYH, FIYT, F. SHAR, G, GAMI, GAMZ, GDT, GGMI1.GGM12,GM11,GM12, I, TABRT, IALL, IAAR,IOTO, IJ,

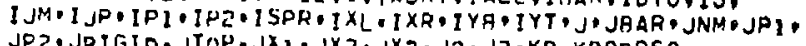

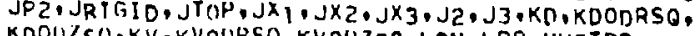
KOOUZSO.KV, KVOURSO, KVOUZSA. LCM . LPA, MUSTPR, MUSI HO NAME (8) -NCYC.NLC NPTOT, NO, NOI, NOIZ NOL, NQP. PHQZL, NSC, NUMIT, NUMRO, NUMTD, NIJV, NUV3, NVAP, OMHAS, OMESPL OMP, OMRO, R, RCONT (66), RDR,

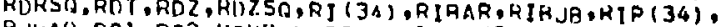

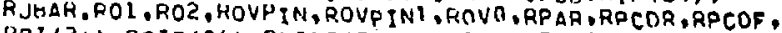
RRI (34) ARRIP (34), RIIOR (3A), RROI, RRO2, RZOR, R2DZ, SIEVINOSHMO.T, THIN, TH YQOYCONV, 
SINGLY REFERENCED VARIABLES

\begin{tabular}{|c|c|c|c|c|c|c|c|c|c|c|c|c|c|c|c|c|c|c|c|}
\hline \multirow{2}{*}{\multicolumn{20}{|c|}{ F J4AR }} \\
\hline & & & & & & & & $3 \mathrm{CO}$ & $\mathrm{JP}_{2}$ & -1 & NOL & -1 & & & & & & & \\
\hline$\Delta A !$ & 115 & $2 \mathrm{CO}$ & DIOC & (1)R & 300 & G & $-R$ & $3 \mathrm{CO}$ & JRIGID & $3 \mathrm{Co}$ & NOZL & -1 & $\begin{array}{l}3 \mathrm{CO} \\
3 \mathrm{CO}\end{array}$ & RIJPC & 19 & 26EN & $50 \times 0$ & $-R$ & $3 C 0$ \\
\hline AKINFI & $-F$ & $3 \mathrm{Co}$ & DTOUR & $-h$ & 300 & GAMI & $-H$ & $3 r .0$ & JOP J & $3 \mathrm{CO}$ & NSC & -1 & 300 & & WR & 300 & START & & BEN \\
\hline An & -1 & $3 \mathrm{CO}$ & 01002 & $-R$ & 300 & GAMZ & $-\beta$ & $3 \mathrm{Co}$ & $\mathrm{j} 2$ & 300 & NUMIT & -1 & $\begin{array}{l}3 \mathrm{CO} \\
3 \mathrm{CO}\end{array}$ & : IAAR & $-R$ & $3 \mathrm{Cn}$ & & $-R$ & 300 \\
\hline BDTODR & -6 & $3 \mathrm{CO}$ & oto2 & $-R$ & 300 & GOT & $-R$ & 300 & J3 & $3 \mathrm{CO}$ & NUMRO & -1 & 300 & $\begin{array}{l}\text { RL ' IN } \\
\text { ROV. NI }\end{array}$ & $-R$ & $3 \mathrm{co}$ & THTN & $-R$ & $3 \mathrm{CO}$ \\
\hline BDTOOZ & -5 & $3 \mathrm{Cn}$ & DTPOS & $-R$ & $3 \mathrm{co}$ & $G\left(G M_{11}\right.$ & $-R$ & $3 \mathrm{CO}$ & KO & $3 \mathrm{CO}$ & NUMTD & $-I$ & 300 & $\begin{array}{l}\text { ROV. NI } \\
\text { ROVO }\end{array}$ & $1-2$ & $3 c 0$ & THO & $-R$ & $3 r 0$ \\
\hline Rol & -1 & $3 \mathrm{CO}$ & & $-n$ & 300 & GGHiz & -2 & $3 \mathrm{CO}$ & KDOORSO & $3 \mathrm{CO}$ & NUV & $-I$ & $3 \mathrm{Co}$ & $\begin{array}{l}\text { ROV } \\
\text { R01 }\end{array}$ & $-R$ & $3 \mathrm{CO}$ & ILTMD & $-R$ & $3 c 0$ \\
\hline $\begin{array}{l}\text { BDZ } \\
\text { BINF }\end{array}$ & -1 & $\begin{array}{l}3 \mathrm{Co} \\
3 \mathrm{CO}\end{array}$ & 0202 & $\begin{array}{l}-8 \\
-8\end{array}$ & 300 & GMll & -8 & $3 \mathrm{CO}$ & KDกOZSA & $3 \mathrm{CO}$ & NUV 3 & -1 & 300 & $\begin{array}{l}\text { RO1 } \\
\text { R02 }\end{array}$ & $\begin{array}{l}-R \\
=R\end{array}$ & $\begin{array}{l}35.0 \\
360\end{array}$ & TOP & $-R$ & $3 \mathrm{Cn}$ \\
\hline BOUT & -1 & $\begin{array}{l}3 \mathrm{Cn} \\
3 \mathrm{CO}\end{array}$ & $\begin{array}{l}\text { n2so } \\
01\end{array}$ & $\begin{array}{l}-R \\
-R\end{array}$ & $\begin{array}{l}3 \mathrm{CO} \\
3 \mathrm{CO}\end{array}$ & $\begin{array}{l}\text { GMIR } \\
\text { IAHRT }\end{array}$ & $\begin{array}{l}-1 \\
-8\end{array}$ & $3 C 0$ & $\begin{aligned} \mathrm{KSB} \\
\times 55\end{aligned}$ & $2 \mathrm{CN}$ & NVAP & $-i$ & 300 & RPAR & $-R$ & $3 \mathrm{Cn}$ & $\begin{array}{l}\text { TRUT } \\
\text { TWF IN }\end{array}$ & $\begin{array}{l}-R \\
-R\end{array}$ & $\begin{array}{l}3 \mathrm{CO} \\
3 \mathrm{CO}\end{array}$ \\
\hline $8 V_{1}$ & -5 & 360 & EMIO & -8 & $3 \mathrm{co}$ & IALL & $\begin{array}{l}-1 \\
-1\end{array}$ & $3 \mathrm{CO}$ & $\begin{array}{l}\text { KSC } \\
\times V\end{array}$ & $3 \mathrm{CN}$ & OMBAS & $-A$ & $3 \mathrm{CO}$ & RPARU & - & $3 I E N$ & TZOMD & $\approx R$ & 300 \\
\hline 8V1GM11 & $1-f$ & $3 \mathrm{Cn}$ & $E \times 3$ & $-R$ & $3 \mathrm{CO}$ & $I B A R$ & $-i$ & 360 & KVODRSO & $\begin{array}{l}3 \mathrm{CO} \\
3 \mathrm{Cn}\end{array}$ & $\begin{array}{l}\text { OMBSPL } \\
\text { OMF }\end{array}$ & $\begin{array}{l}-8 \\
-8\end{array}$ & $3 C 0$ & RPARY & - & 34EN & VOL & (1) $\mathrm{R}$ & $3 \mathrm{CO}$ \\
\hline $\begin{array}{l}\text { BV? } \\
\text { HV? }\end{array}$ & -1 & $3 \mathrm{Cn}$ & EM6 & -8 & $3 \mathrm{CO}$ & IDTO & -1 & $3 \mathrm{Co}$ & KVODZSO & $3 \mathrm{CO}$ & OHRO & $\begin{array}{l}-h \\
-8\end{array}$ & $\begin{array}{l}3 \mathrm{Cn} \\
3 \mathrm{CO}\end{array}$ & $\begin{array}{l}\text { RPCDR } \\
\text { RHCOF }\end{array}$ & $-A$ & $3 \mathrm{co}$ & VOLA & 118 & $36 n$ \\
\hline $\begin{array}{l}\text { BV?GMI2 } \\
80\end{array}$ & $2-1$ & $3 \mathrm{CO}$ & EPS & $-i^{-H}$ & $3 c 0$ & IFl & -1 & $3 \mathrm{CO}$ & LCMFLG & 23EN & & $-A$ & $\begin{array}{l}3 \mathrm{Cn} \\
3 \mathrm{CO}\end{array}$ & $\begin{array}{l}\text { RPCDF } \\
\text { RRI }\end{array}$ & ${ }_{i R}^{-R}$ & $\begin{array}{l}3 \mathrm{Cn} \\
3 \mathrm{CO}\end{array}$ & VVIN & $-R$ & $3 \mathrm{co}$ \\
\hline CDR & $\begin{array}{l}-1 \\
-1\end{array}$ & $\begin{array}{l}3 \mathrm{CO} \\
3 \mathrm{CO}\end{array}$ & $\begin{array}{l}\text { EPV } \\
\text { EPIO }\end{array}$ & $\begin{array}{r}\| R \\
-R\end{array}$ & $\begin{array}{l}3 \mathrm{CO} \\
3 \mathrm{CD}\end{array}$ & $\begin{array}{l}I P_{2} \\
I S P_{R}\end{array}$ & $\begin{array}{l}-1 \\
-1\end{array}$ & $3 \mathrm{CO}$ & LOOP & 150 & RCONT & $\| R$ & 300 & RRIDR & i) $R$ & $\begin{array}{l}3 \mathrm{CO} \\
3 \mathrm{CO}\end{array}$ & $\begin{array}{l}\text { WIRON } \\
\text { XCONV }\end{array}$ & $-R$ & $\begin{array}{r}21 E N \\
3 C 0\end{array}$ \\
\hline COLOUR & (I) & $3 \mathrm{Cn}$ & EP2O & $-R$ & 300 & $I X_{L}$ & -1 & 300 & $\begin{array}{l}\text { LPR } \\
\text { MUSTPR }\end{array}$ & $\begin{array}{l}3 \mathrm{CO} \\
3 \mathrm{Cn}\end{array}$ & $\begin{array}{l}\text { ROR } \\
\text { RORSO }\end{array}$ & $-R$ & $3 \mathrm{CO}$ & RRIP & in $R$ & $3 \mathrm{CO}$ & $\hat{x}_{l}$ & $-A$ & $3<0$ \\
\hline & -1 & $3 \mathrm{Cn}$ & EP9 & $-R$ & $3 \mathrm{CO}$ & $i \times p$ & $-i$ & $3 c 0$ & MUSTRO & $3 \mathrm{Cn}$ & $\begin{array}{l}\text { RORSO } \\
\text { ROT }\end{array}$ & $-\mathbf{R}$ & $3 \mathrm{CO}$ & $R H()]$ & $-R$ & $3 c 0$ & $x p$ & (IR & 300 \\
\hline DONE & & I3EN & $F J B A R$ & $-R$ & $30^{\circ}$ & IYB & $-\hat{I}$ & $3 c 0$ & NAME & $3 C 0$ & ROZ & $\begin{array}{l}-8 \\
-8 \\
-8\end{array}$ & 300 & RRO? & $-R$ & $3 \mathrm{CO}$ & $X R$ & $-R$ & $3 C 0$ \\
\hline DR & -1 & $3 \mathrm{CO}$ & FIXL & $-\pi$ & $3 \mathrm{CO}$ & IYT & $-J$ & $3 \mathrm{CO}$ & NCYC & $3 \mathrm{CO}$ & RO250 & & $3 \mathrm{Co}$ & RIHOW & - & I5EN & & $-R$ & 300 \\
\hline ORO? & -1 & $3 \mathrm{C} 0$ & $F I X R$ & $-R$ & $3 c 0$ & $J B A R$ & $-I$ & $3 \mathrm{CO}$ & $N L C$ & $3 C 0$ & $R !$ & $i_{R}^{-R}$ & $3 \mathrm{CO}$ & R2OR & $-R$ & $3 c 0$ & Y SONV & $-R$ & 300 \\
\hline ORSO & -1 & 300 & FIYB & -8 & 300 & JNM & -1 & $3 \mathrm{CO}$ & NPTOT & $3 \mathrm{co}$ & RIBAR & $\because A$ & $3 \mathrm{CO}$ & 12202 & $-R$ & $3 \mathrm{CO}$ & YP & (IR & 300 \\
\hline DT & -1 & $3 \mathrm{CO}$ & FIYT & $-R$ & $3 c 0$ & JP $\mathbf{I}$ & $-I$ & $3 \mathrm{CO}$ & NOI & $3 \mathrm{CO}$ & RIBJB & $-R$ & $3 \mathrm{CO}$ & SET I I & - & $\triangle B E N$ & & $-P$ & $3 \mathrm{CO}$ \\
\hline \multirow{3}{*}{\multicolumn{20}{|c|}{ 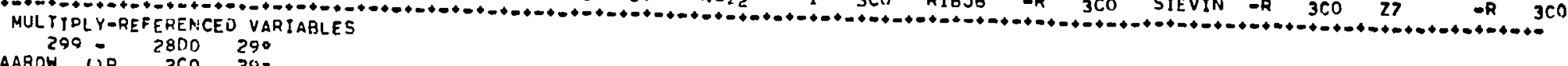 }} \\
\hline & & & & & & & & & & & & & & & & & & & \\
\hline & & & & & & & & & & & & & & & & & & & \\
\hline$\triangle A R O H$ & $1 R$ & $2 \mathrm{CO}$ & $29=$ & & & & & & & & & & & & & & & & \\
\hline COMMON & IR & $\begin{array}{l}3 \mathrm{CO} \\
2 \mathrm{~F}\end{array}$ & ${ }_{35}^{29}$ & & & & & & & & & & & & & & & & \\
\hline ENTRY & & $B F$ & $13 F$ & $15 \mathrm{~F}$ & $18 F$ & $21 \mathrm{~F}$ & $23 F$ & $26 \mathrm{~F}$ & $3)^{F}$ & $34 F$ & & & & & & & & & \\
\hline IT & -1 & $3 \mathrm{CO}$ & 19 & & & & & & & & & & & & & & & & \\
\hline IJM & -1 & $\begin{array}{l}3 \mathrm{CO} \\
3 \mathrm{CO}\end{array}$ & $\begin{array}{l}5= \\
6=\end{array}$ & 5 & $\begin{array}{l}10 x \\
11=\end{array}$ & $19 x$ & $32=$ & $35=$ & & & & & & & & & & & \\
\hline $\mathrm{JP}$ & 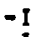 & 300 & $4=$ & 4 & $0=$ & & & & & & & & & & & & & & \\
\hline JJ & - & $\begin{array}{l}3 \mathrm{C0} \\
16=\end{array}$ & 16 & 27 & 32 & 35 & & & & & & & & & & & & & \\
\hline$j \times 1$ & $-i$ & $3 \mathrm{Cn}$ & ij & & & & & & & & & & & & & & & & \\
\hline Jx? & -1 & $\begin{array}{l}3 c 0 \\
3 c 0\end{array}$ & $\begin{array}{r}10 \\
9\end{array}$ & & & & & & & & & & & & & & & & \\
\hline$j \times 3$ & -1 & $\begin{array}{r}3 C 0 \\
2800\end{array}$ & $\begin{array}{r}9 \\
29\end{array}$ & 29 & & & & & & & & & & & & & & & \\
\hline KK. & $\begin{array}{l}-1 \\
-1\end{array}$ & $\begin{array}{l}2800 \\
27=\end{array}$ & 29 & $\Rightarrow$ & & & & & & & & & & & & & & & \\
\hline LCM & $-I$ & 300 & $24=$ & & & & & & & & & & & & & & & & \\
\hline NO & -1 & 360 & 19 & & & & & & & & & & & & & & & & \\
\hline $\begin{array}{l}\text { NoI } \\
\text { NGS }\end{array}$ & $\begin{array}{l}-I \\
-I\end{array}$ & $\begin{array}{l}3 \mathrm{CO} \\
3 \mathrm{CO}\end{array}$ & 16 & $\begin{array}{r}27 \\
5\end{array}$ & 2000 & 32 & 35 & & & & & & & & & & & & \\
\hline RE TUJRN & 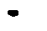 & $7 F$ & $12 F$ & $14 F$ & $17 F$ & $20 F$ & $2 ? F$ & $25 F$ & & 335 & & & & & & & & & \\
\hline & & & & & & & 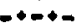 & 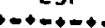 & or & 33t & F & & & & & & & & \\
\hline
\end{tabular}


INDEX 01/00/75

$$
\begin{aligned}
& 1 \\
& 2 \\
& 3 \\
& 4 \\
& 5
\end{aligned}
$$

PROGRAM KASET

PRINT 10

CALL SETUP

ENO
PROGRAM KASET

PAGE

KASET

KASET

KASET

KASET

KASET

INDEX $01 / 00 / 75$

PRogram KASET

PAGE

SINGLY REFERENCED YARJAGLES

FORMAT - 4F KASET - ISU PAINT - 2F SETUP - 3SU

MULTIPLY-REFERCHCEO VAHIABLES

10 - ZPR - 
AOI AASC (26676), AKTNF I, AD, BUTODA, ROTODZ,

KON

BOJ,BD2, BINF, BOUT , RVI, BVIGMII, BVZ, BVZGMI2,

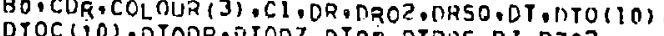

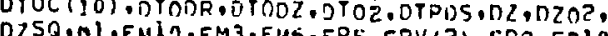

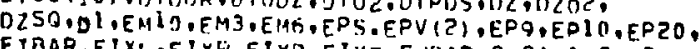

FIBAR, FIXC,FIXFi, FIYB, FIYT F JAAR, G, GAMI, GAMZ, GDT,

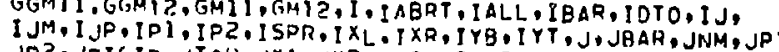

JP2, JRIGID, JTOP, JXI, JX2, JX3,J2,J3,KD, KUOORSO.

KUOUZSU,KV,KVODFSO,KVOQZSQ,LCM,LQR, MUSTPR,

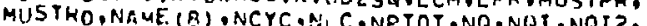

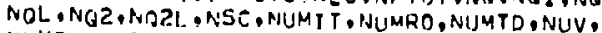

NUV 3 , NVAPF, OHBA S, OMBSPL, ONP O OMRO R R RCONT (66) , RDR

RURSO,RDT, RDZ ROZSORI (3A),RIOAR RIB JP RIP (34)

RJPAH, KOI, HOZ, ROVPIN, ZOVPINI, ROVD, RPAR, RPCOR, RPCOF,

RRI (34), RPID (34), RR IDR (3/), RROI, HAO2,RZDR,RZDZ,

SIEVIN,SOMO, T, THIN, THOE, TLIMD, TOP, TOUT, TWFIN,

T2OMO,VDI. (34), VOLR (34), VVIN, XCONV, XL, XP (4000), XR,

YAASC (I) OTH) (AAASC (2), ROVPR) ), (AASC (3), ROOPRI),

(AASC) PPOVPR) (AASC (5) RRODP), (AASC (6)) SIEV).

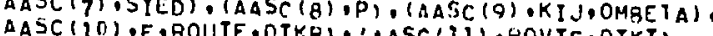

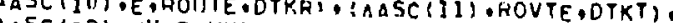

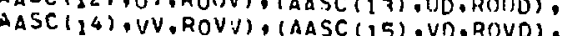

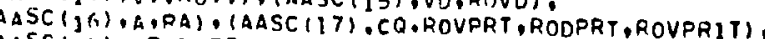

EOUIVALENICF

(AASC (1B),PD,DPRT), (AASC (19),F)

ENUIVALENCE (EPV (2), EPD)

UIMENSION THII) HOVPHI , KI J,KV,KVODRSR,KVONZSO,NUV, NUVZ

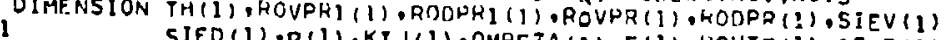
SIEO (1),P $(1), K I J(1)$,OMAFTA $(1)$, E $(1)$, HOUTE (1),OTKR(1):

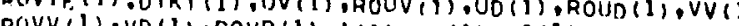
DOVV (1) VDD (1), ROVD(1),A(1),RA(1), CG (I) , ROVPRT (1). DIMENISION ROVSPL 11,

OATA PI, 3.1415926535897932384626

DIMEHSIOH TOCOMP (A), KMATS (4)

DAIA KHATS $108,18.28,38$

CALL LCMFLG

READ BIT, MAME

RE.AO 819 , TOCOMP

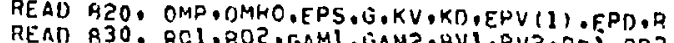

,

READ A35, JRIGIO,IGOT, THIN, ROVINI, ROVIN2, SIEVIN, VVIN,ITOP

READ A40, T.OT. TZ OMI), TLIMD, TWF IN, LPR, I SPR, (COLOUR (N) , N=1,3)

REAO 845, (DTO $(N), N=1,10)$

READ $=$ ?

WRITE 110 TO KRET

WRITE $(K T, B I D)$ IDCOMP

WRITE (KT,B5O) IEAR,JBAR.OR,DL,AO,BO,ROVOANUV,COR, RPAR

WHITE (KT,RGA) OMP.OMRO,EPS,G,XVIKD,EPV (I),EPO,R

DIMFN

DINFN

DIMFN

DIMFN

KASET

KASET

KASET

KASET

KASET

KASE

KASET

KASET

KASET

KASET

KASET

KASET

KASET

KASET

KASET
KASET 


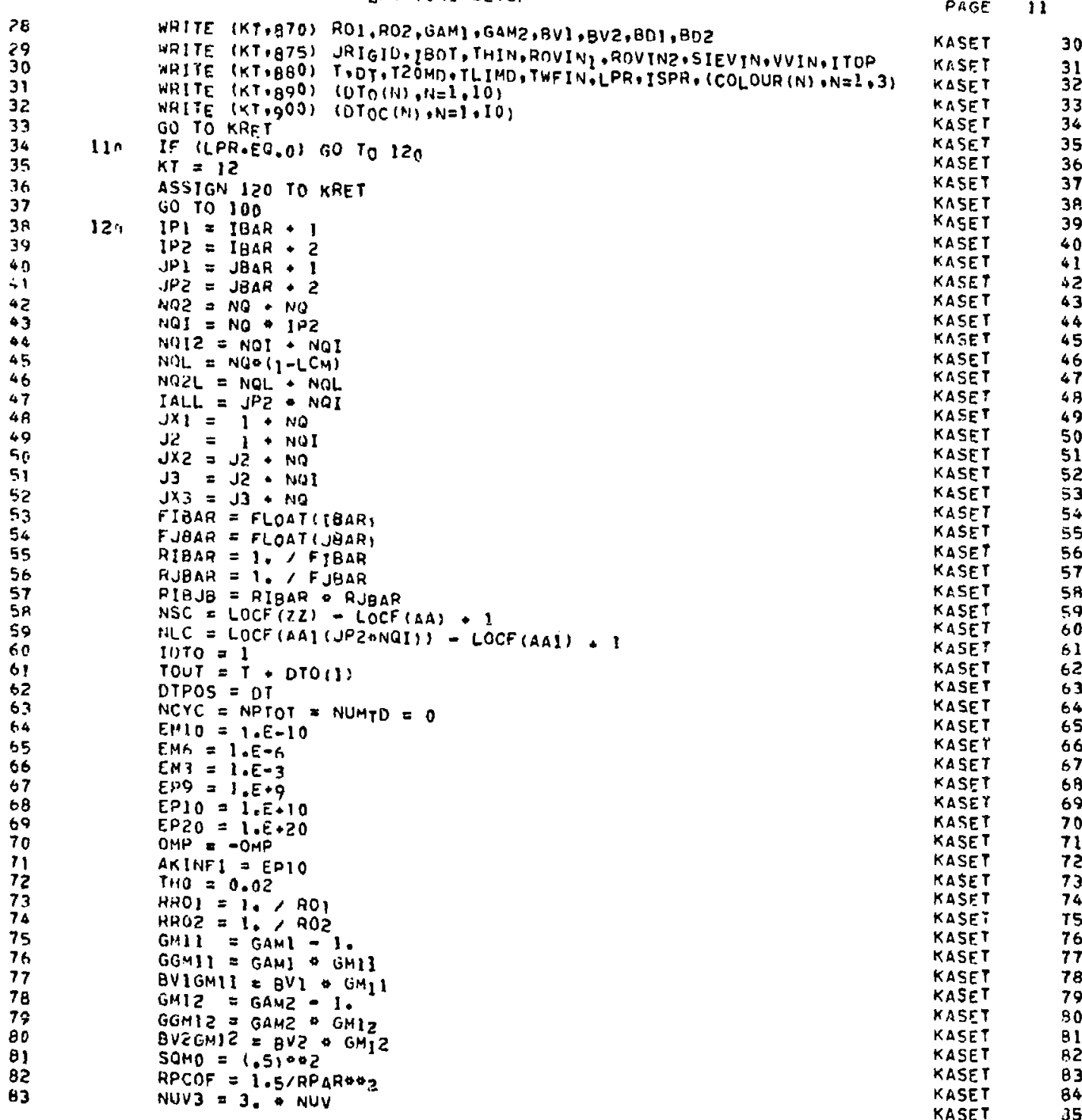


$O R O 2=1.0 R$

ROZ $=1.1 \mathrm{DZ}$

$202=.5 \% 02$

RORSO = RDR R RU

KASET

KASE.T

KASET

ROZSQ $=R O Z \cdot R I J Z$

ORSQ $=O A: O R$
$O Z S O=0 Z: O Z$

OMBAS $=.500 M P O O R S O 00250$, CORSQ DZZ5O

KASET

KASET

KASET

ROR $=.5 *$ RUR

KVODRSO. $R O Z$

KVODRSO = KV RORSO

KDODRO = KV:ROZSO

KDODZSO = KO: RDZSO

HIIT $=1.1 \mathrm{DT}$

UTOZ $=1.5$. DT

OTODR = OT: ROR

BDTODR $=$ BO $*$ DTOOR

DTOOZ $=D T \circ R O Z$

BOTOOZ = BO DTODL

$\checkmark$ OHASPL $=2$ OMBAS ROAT

$H I(1)=. .5 * D R$

RRI (1) $=-2$. ROF

RRIOR(1) = RRI (1) $: R D R$

$R I P(I)=R_{R}(P(1)=0$.

DO 129 I $=2, I P 2$

$R[(1)=R I(I-1)+D R$

$R A I(I)=1.1 R[(I)$

RRIOR(I) = RRIII) * ROR

RIP(I) $=R_{T} P(I-1)+D R$

VOLIR = VCON"RIII)

RQLR(I) = VCONOR

RC(INT (J)

IF (J.GE.JPIÓID+Z) RCONT(J) $=1$.

CONTH

BOT $=$ AINF $=0$.

If (IBOT-EO.1) BOUT $=1$

HOVPINT B THIN A ROVINI.

ROVPIN = THIN QROVINI+ROVINZ)

TUP $=1$ TOP

JTOP $=$ JPI + ITOP

$X R=F I B A R: O R$

$Y T=F J_{B A H} \otimes D Z$

$X L=Y A=0$.

FIYB $=916$

$X U=X R_{0},|Y T-Y B\rangle$

$Y Y=0$.

IF (XD.LE.1.13556) YY $=1$

$F I X L=A M A X](0, *(5,1,-450 \cdot * X 0) * Y Y)$

KASET

KASET

KASET

KASET

KASET

KASET

KASET

KASET

KASET

KASET

KASE T

KASET

KASET

KASET

KASET

KASET

KASET

KASET

KASET

KASET

KASET

KASET

KASET

KASET

KASET

KASET

KASET

KASET

KASET

KASET

KASET

KASET

KASET

KASET

KASET

KASET

KASET

KASET

KASET

KASET

KASET

KASET 
ICONV = (FIYT-FIYB), (YT-YB)

$I X_{L}=F I X L$

IXR $=F I X R$

IXR $=$ FIXR
IYT $=$ FIYT

NOML = NO - 1

LO $199 \mathrm{~J}=1 . \mathrm{JPz}$

KF $189 \mathrm{I} I=1.102$

$K L=K F$. NOH

UO $179 K=K O M F I$

179 AASC (K) $=0$.

$1 \mathrm{JM}=1 \mathrm{JM}$ ? $\mathrm{NA}$

199 IJM $=1 \mathrm{JM}-\mathrm{HQO}_{2 L}$

CALL DONE

KASET 143

KASET 194

KASET 145

KASET 147

KASET 148

$\begin{array}{ll}\text { KASET } & 149 \\ \text { KASET } & 150\end{array}$

KASET 151

XASET 153

KASET $\quad 154$

XASET $\quad 156$

KASET I57

$\begin{array}{ll}\text { KASET } & 158 \\ \text { XASET } & 150\end{array}$

SROV $=$ SROVZ $=0$

KASE

KASET

IF (NR, E, HB, MRR, NI, NL, HOOPRI I RODPRI , AOVI, ROVZ, SIEVI, SIEOI, NPUA

PRI NT 920 : NB , NR, NT . NL, RODPRII, RODPRII, HOVI, ROVZ, SIEVI, SIEDI, NPUA 1

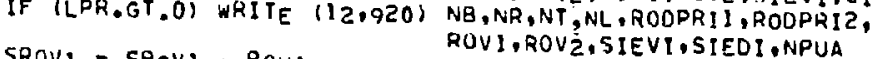

SROV = SROVI: ROV

NBZ $=$ NB * 2

$N R 1=N R: 1$

$N T=N R:$

THI = 1 - - RODPRIISAHOI - RONPRIZORROZ

IF (THI.LT=0.) GO TO 400

ROVPRI $=$ THT OROVI

HOOPRI = RHT (RUVI+ROV?)

ROVPRIT = ROVPRT PODPRIZ

PNI = SIEVTOLROVPR ROVPRI

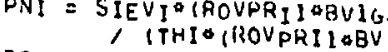

KASET

KASE

KASET

KASET

KASET

KASET

KASET

KASET

KASET

KASEY

XASET

XASET

KASET

KASET

KASET

KASET

KASET CALL RIROW

DO 20? I FNLE.NAI

CALL SETIJ

ROVERI (IJ)

ROVPR (IJ) ROVPRI

HOUPRI (IJ) = ROOQR I

RODPR (I J) = RODPHI

KASET

KASET

KASET

KASET

KASF.T

KASET

KASE

KASE.

KASE

STEU(IJ) a SIEDI

I $(J J)=P N T$

$I J=I J \cdot N O$

219 CUNTINUE

If (NPUA.EO.O) GO IO 200

KASET

KASET

KASET

KASET

KASE 
FNT = FLOAT (NT)

FNL = FLDAT (NL)

WIDTH = FTS - FNL

HEIGHT $=$ FNT - FNB

FNPUA = FLOAT (NPUA)

ROOKAT = ROOFRI1 / RODPA

OFFSET 30

DO 299 NTYPE=1,3

GO TO $(230,232,234)$ NTY.

PNEFF 2 FNPUA - RUDRAT $(1, .-T H I)$
GO TO 240

232 PNEFF $=$ FNDUA - $(1$, -ROORAT $)(1,-$ THI $)$

60 TO 240

F FNPUA $*$ THA

$240 \quad X N P=$ WIOTHOQSURT (PNEFF)

YHP N MEIGHT OXNP/WIDTH

$N P X=X N P+.5+E M I D$

$N P Y=Y N P+.5+E M ! O$

IF (ANPXNPY.EO.D) 60 TO 299

$X 1=F N L$ Y XSOAC 15 T

YSPAC = HEIGHT, FIOAT (NPY)

$Y 1=F N B \cdot Y 5 P A C * 1.5 * .2540 F F S E Y)$

KMAT = KMATS INTYPE)

OO $289 \mathrm{~J}=1$, NOY

$X T E=X I$

DO 279 I $=1$. NPX

NPTOT = NPTOT

$X P(N P T O T)=\left(X T E_{0} A, . N, 3 B\right), 0$. KMAT

YP(NPYOT) $=Y$

279 XTE = XIE XSPAC

$289 \quad Y 1=Y_{1}+Y S P A C$

200

300 CALL START

DO $399 \mathrm{~J}=2$. JP1

IF (I.EQ.2) GO TO 330

310 if (J.E.Q.Z) GO TO 335

315 if (I.EQ.IPI) 5O To 340

IF (J.EO.JP) $G 0$ To 345

330 IN $=$ IJ.

KRET $=1$

335 IN

KRET : 2

$T H(I N)=T H(I J) \cdot B I N F *(T H I N-T H(I J))$

ROVPRIIIN) = AOVPRIIIJ) + BINFO (ROVPINI -ROVPRIIIJ)

HOVPR(IN) = ROVPR (IJ) BINFA (ROVPIN-ROVPA (IJ))

SIEV(IN) = SIEVIIJ) * BINFA(SIEVIN-SIEV(IJ))

VVIIN) $=$ BINFAVUIN

$340 \quad I N=I J \cdot N Q$

KASET

KASET

KASET

KASET

KASET

KASET

KASET

KASE

KASET

KASE

KASE

KASET

KASET

KASET

KASE

KASET

KASET

KASET

KASET

KASET

KASET

KASE

KASET

KASET

KASET

KASET

KASET

KASET

KASET

KASET

KASET

KASET

KASE

KASET

KASET

KASE T

KASET

KASE?

KASET

KASET

KASET

KASET

KASET

KASET

KASET

KASE

KASE

KASFT

KASET 
KRE T $=3$

KASET

$\begin{array}{lll}251 & & G 0 \\ 25 & 30350 \\ 25 ? & 345 & \text { IN }=I J P \\ 243 & & K A E T=4\end{array}$

KASET TSS

243
254
255

ROVPRIIIN) = ROVPR!(!J)

KASE

ROVPAIIN) = ROVPR (I)

KASE

255

RIFO(IN) = ROOPR (Ij)

KASE

SIFOTIN $=$ SIED(IJ)

KASET 532

IP

KASE

KASET

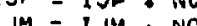

$389 \quad I J=1 J \cdot N O$

CALL DONE

CALL DONF

IF (SROV).GT.0. .A. SRDVZ.EO.0.) NUAD $=2$

KASET

KASET

KASET

KASFT

IF (SHOVI.GT.0.A. SHOVZ.GT.0.) NVAP $=3$

IF ILPA.GT.0) WRITE $(12.930)$ NPTOT

400

PRINT

IHI

RE IURN

KASET

Kaser

KASEY

KASET

KASE

KASET

KASET

KASET

KASET

FOAMAI (BAIO)

KASET

FORHAT (9F8.3)

FGRMRt 1858.31

Format (214.5f8.3.19)

FrPMat 15FB.3.214.3F4.11)

KASET

KASET

FORMAT llOFB.3.

KASET

KASET

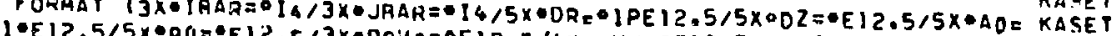

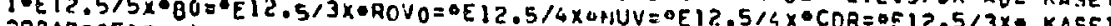
chish=cis.

$2^{B 3}$

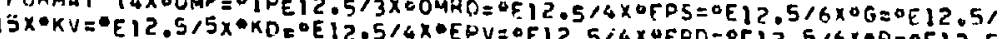

KASET

28

285

875

F

KASET

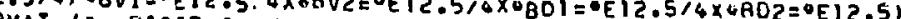

8EO

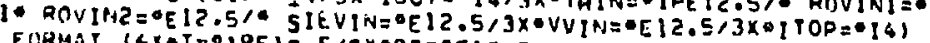

286

110 TwF $16 x+1=0,10$

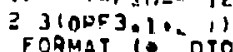

287
286

890

(1) '

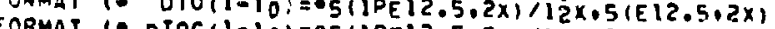

FRMAT 10 OTRC $(1-10)=05(1 P E 12.5,2 x) / 12 x, 5(F, 12.5,2 x)$

FCPMST (S)

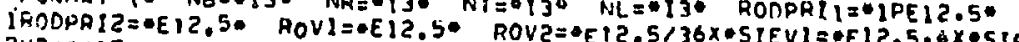

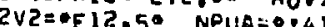

291
292
393

930

FOHHAT IIOX NEGATPUES GENERATED. SETUP COMPLETED.•

EHD

KASET

KASET

KASET

KASET

KASET

KASET

KASEY
KASET

KASET

KASEY

KASET

KASET 
SINGLY REFEHENCEE YAOIAHLES

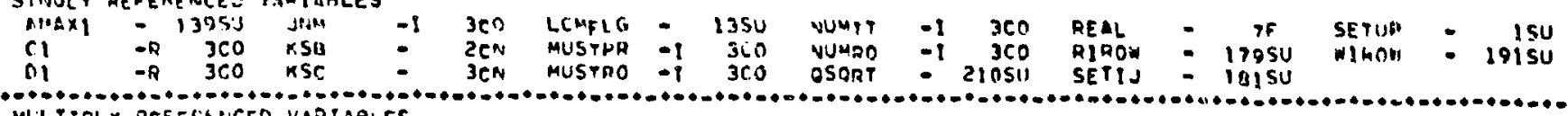

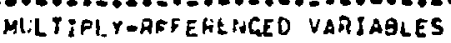

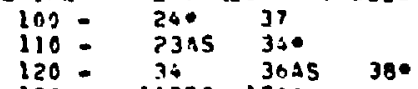

$120=13600$ 28045

$179-11300$ 1200
$139-12100$ 1?40

$179 \div 15400155^{\circ}$

JPG - J5100 156.

2ro = $161.0190^{\circ} \quad 220$

2no:- 16000 1700

219: 17800 1920

$270: 204$ 3950

$233=204 \quad 2070$

$500=20125002100$

270 - 32?0n 3200

2n: - $23,0 \mathrm{~s} 2270$

$299-303110216$

3 no: 132 $230^{\circ}$

$310-23402(1)$

$350=736 \circ 261$

$330=233$ 2300

$375-234$ 2410

$360=2352690$

$365=236 \quad 2570$

251254

$360=2312612620$

$300=201$

$300-331102050$

$400=1720$

Q10: 1600 IFRD 24\%R 2469 2760

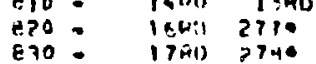

a.s.

8.0 - lapo 2700

A०5:- टाPी हासD 2010

क5० - $260 \mathrm{H}$ 29>0

$660-27-51030$

P7O - 2WWA 784

P.75 - 204 2054

890 - 30W 285.

$890=31 \mathrm{kP}$ 2070

$900-37$ IAH 2 दH

910 - ThIM 2990

920 - 16.3PH 1654H 290

940 - 27364 \% 2420

i) 


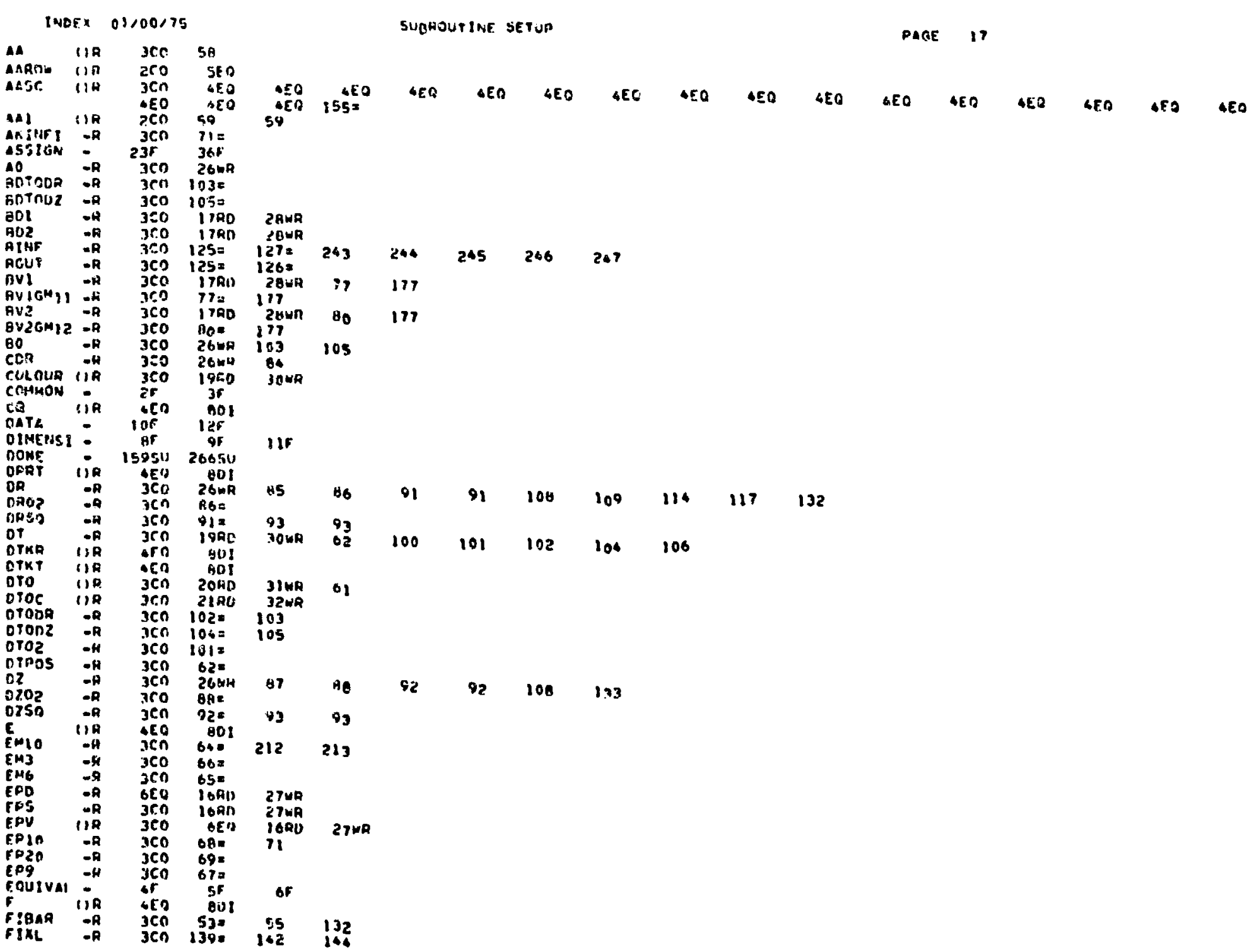




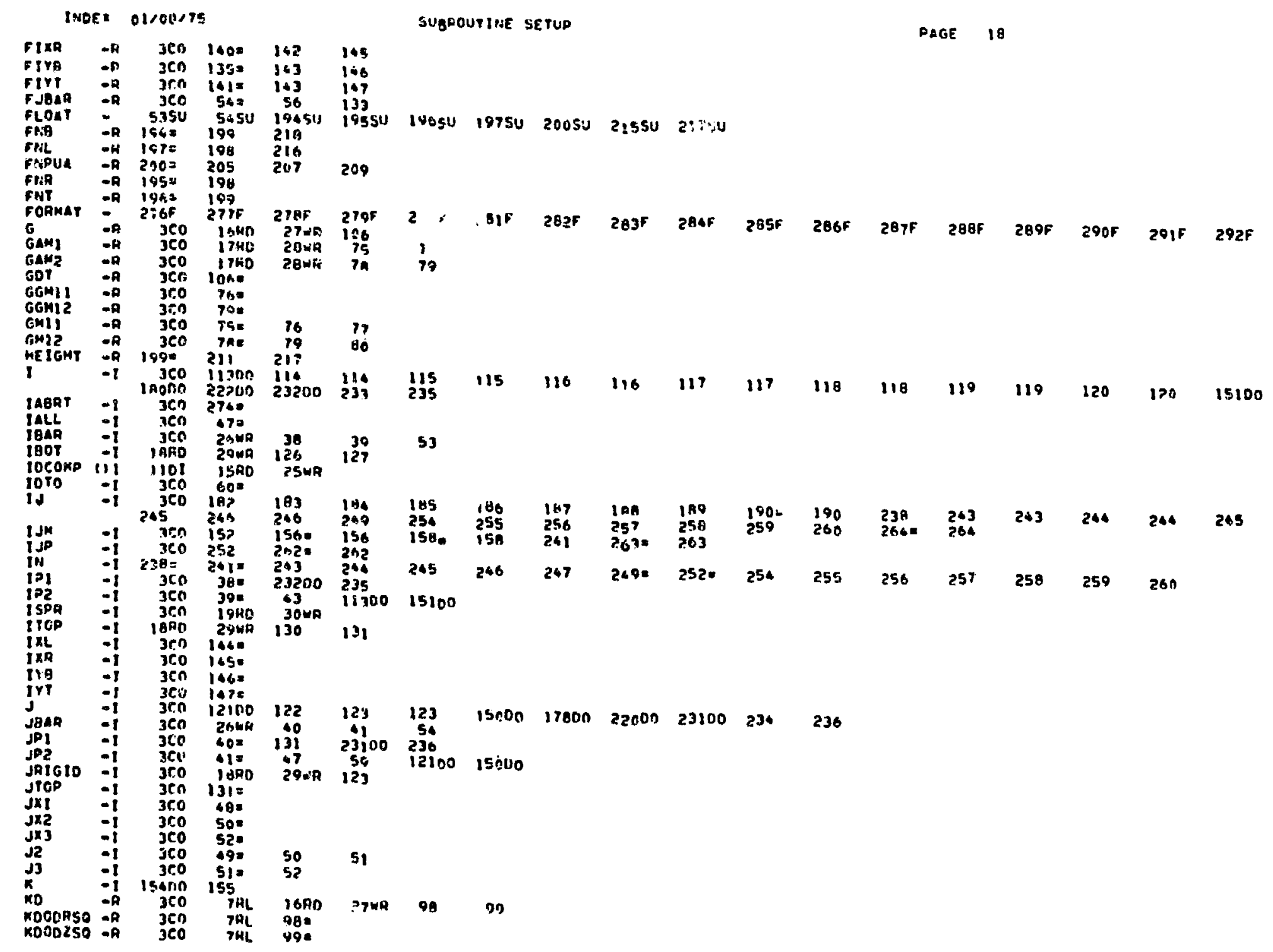




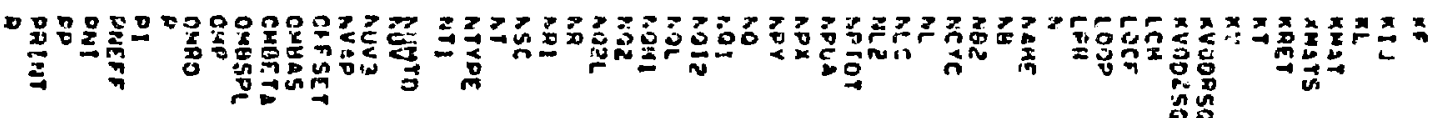

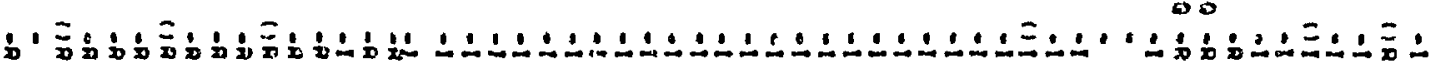

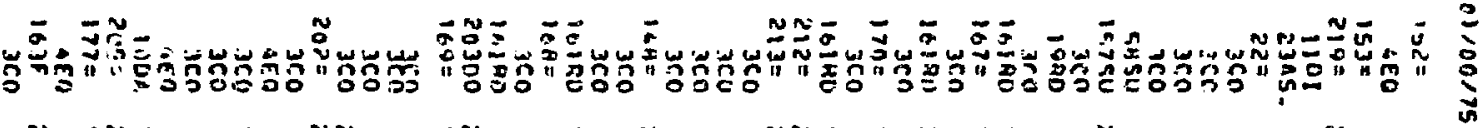

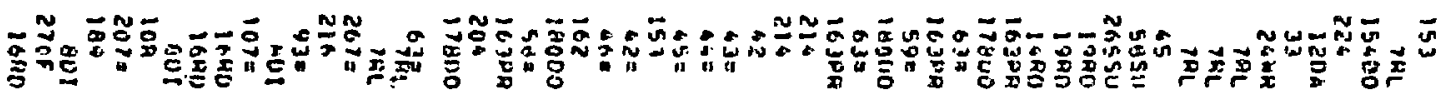

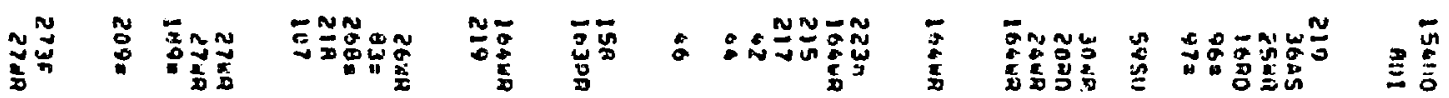
ㅁำ

\begin{tabular}{|c|c|c|c|c|}
\hline : & $\bar{\alpha}$ & : & $\tilde{\Xi}$ & $\bar{x} \frac{\bar{y}}{\bar{g}}$ \\
\hline \multirow[t]{7}{*}{$\stackrel{\sim}{\infty}$} & $\ddot{\text { ज̆ }}$ & $::$ & $\underset{\sim}{N}$ & $\stackrel{n}{\pi}$ \\
\hline & & תם & 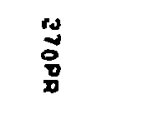 & 岕 \\
\hline & & บี & $\underset{\tilde{x}}{\tilde{D}}$ & 虫 \\
\hline & & $\bar{\Phi}$ & & $\underset{\square}{\underline{D}}$ \\
\hline & & $\overline{\mathfrak{N}}$ & & $\underset{\mathbf{D}}{\mathrm{D}}$ \\
\hline & & $\bar{n}$ & & 岕 \\
\hline & & $\bar{\Xi}$ & & 岌 \\
\hline
\end{tabular}

$\tilde{\Xi}$ 


\begin{tabular}{|c|c|c|c|c|c|c|c|c|c|c|}
\hline \multicolumn{2}{|c|}{ INAE: } & \multicolumn{2}{|c|}{ a)/4n/75 } & \multicolumn{7}{|c|}{ SUBROUTINE SETUP } \\
\hline As & 的 & 450 & fOS & & & & & & & \\
\hline $\begin{array}{l}\text { ACONT } \\
\text { GUP }\end{array}$ & $\operatorname{lin}_{-6}$ & $\begin{array}{l}300 \\
300\end{array}$ & $\begin{array}{r}122 * \\
85=\end{array}$ & 1239 & as & & & & & \\
\hline enoso & $-A$ & $3 \mathrm{co}$ & 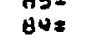 & 96 & Ya & 94 & 102 & 110 & 111 & 116 \\
\hline po! & $\begin{array}{l}-A \\
-A\end{array}$ & $\begin{array}{l}\text { 3en } \\
\text { jeo }\end{array}$ & $\begin{aligned} 100= \\
073\end{aligned}$ & 107 & 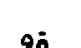 & & & & & \\
\hline $\begin{array}{l}\text { De? } \\
\text { no250 }\end{array}$ & A & 3 co & $90=$ & $\begin{array}{l}90 \\
97\end{array}$ & $\begin{array}{l}90 \\
90\end{array}$ & 95 & 104 & & & \\
\hline AEAO & 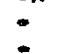 & $\begin{array}{l}165 \\
2725\end{array}$ & $\begin{array}{l}15 f \\
275 f\end{array}$ & $16 r$ & 175 & $18 \mathrm{r}$ & $10 F$ & $20 F$ & $21 F$ & $161 F$ \\
\hline Q: & in & 300 & $104=$ & 1160 & 114 & 315 & 118 & & & \\
\hline $\begin{array}{l}\text { Aigas } \\
\text { a)ด }\end{array}$ & $\begin{array}{l}-6 \\
-\infty\end{array}$ & $\begin{array}{l}360 \\
3<0\end{array}$ & $\begin{array}{l}55= \\
57=\end{array}$ & 57 & & & & & & \\
\hline alp & $\| \hat{R}$ & $36 n$ & $112=$ & $117=$ & 118 & 119 & 120 & & & \\
\hline $\begin{array}{l}\text { R.PA.3R } \\
\text { ROSPR }\end{array}$ & $\underset{\| A}{O A}$ & $\begin{array}{l}300 \\
420\end{array}$ & $\begin{array}{l}50= \\
\text { 611! }\end{array}$ & ${ }_{I A B}^{57}$ & 2590 & 259 & & & & \\
\hline 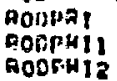 & $\begin{array}{l}-A \\
-A \\
-A\end{array}$ & $\begin{array}{l}175= \\
161 \mathrm{kn} \\
16100\end{array}$ & $\begin{array}{l}18 \mathrm{~K} \\
163 \mathrm{PR} \\
16 \mathrm{JPA}\end{array}$ & $\begin{array}{l}201 \\
164 \times A \\
104 \text { WR }\end{array}$ & $\begin{array}{l}17 i \\
17 i\end{array}$ & $\begin{array}{l}175 \\
175\end{array}$ & 105 & 201 & & \\
\hline ACOPAT & 11日 & $\begin{array}{l}\text { aco } \\
\text { aEO }\end{array}$ & $\begin{array}{l}\text { WDI } \\
\text { HDI }\end{array}$ & & & & & & & \\
\hline $\begin{array}{l}\text { Penga? } \\
\text { mo: }\end{array}$ & $\because a$ & $\begin{array}{l}201=0 \\
\text { EEU }\end{array}$ & $205^{H D 1}$ & $\begin{array}{l}185= \\
207\end{array}$ & $258 *$ & 258 & & & & \\
\hline Govic & iia & SEO & ani & & & & & & & \\
\hline $\begin{array}{l}\text { Potid } \\
\text { Rove }\end{array}$ & \begin{tabular}{ll}
$11 R$ \\
\hdashline$R$
\end{tabular} & $\begin{array}{l}6 E 0 \\
s \in 0\end{array}$ & $\begin{array}{l}401 \\
801\end{array}$ & & & & & & & \\
\hline POVINI & $\boldsymbol{A R}$ & 1000 & $200 \mathrm{R}$ & 128 & 120 & & & & & \\
\hline Aur:s? & $-a$ & 1890 & $29 \mathrm{wK}$ & $\begin{array}{l}129 \\
245\end{array}$ & & & & & & \\
\hline $\begin{array}{l}\text { RovpIn } \\
\text { Moup!n! }\end{array}$ & $\stackrel{-A}{-A}$ & $\begin{array}{l}360 \\
360\end{array}$ & $\begin{array}{l}129= \\
128=\end{array}$ & $\begin{array}{l}245 \\
345\end{array}$ & & & & & & \\
\hline คnupa & 1月 & CEO & 401 & $186=$ & 2450 & 245 & 245 & $256=$ & 256 & \\
\hline 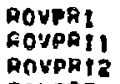 & $\begin{array}{l}-A \\
-A \\
-A\end{array}$ & $\begin{array}{l}174= \\
173= \\
176=\end{array}$ & $\begin{array}{l}178 \\
176 \\
178\end{array}$ & $\begin{array}{l}i 77 \\
177\end{array}$ & 179 & 183 & & 250 & $\cos \theta$ & \\
\hline ROVPAT & 118 & 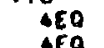 & nol & & & & & & & \\
\hline $\begin{array}{l}\text { ROYPR', } \\
\text { HOUPP IT }\end{array}$ & 110 & 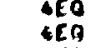 & $\begin{array}{l}\text { AO? } \\
\text { GO! }\end{array}$ & $183=$ & $2+4=$ & 244 & 200 & $255=$ & 255 & \\
\hline $\begin{array}{l}\text { ROYSPL } \\
\text { POYTE }\end{array}$ & i月 & SEg & opi & & & & & & & \\
\hline $\begin{array}{l}\text { Rov' } \\
\text { anve }\end{array}$ & $\begin{array}{l}\because 19 \\
-9\end{array}$ & 460 & 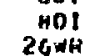 & & & & & & & \\
\hline Doul & $-\theta$ & isian & 10304 & $164 \times 9$ & 105 & 173 & 176 & & & \\
\hline $\begin{array}{l}\text { Hove } \\
\text { gol }\end{array}$ & $\begin{array}{l}-A \\
-A\end{array}$ & $\begin{array}{r}\text { inipo } \\
\text { jen }\end{array}$ & $\begin{array}{l}16304 \\
1890\end{array}$ & $\begin{array}{l}\text { IAG } \\
\text { TOEA }\end{array}$ & $\begin{array}{r}166 \\
73\end{array}$ & 174 & & & & \\
\hline 902 & $=\hat{A}$ & $3 \mathrm{Co}$ & irao & 2ถพด & $i$ & & & & & \\
\hline $\begin{array}{l}\text { GPAP } \\
\text { GPCOA }\end{array}$ & 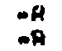 & $\begin{array}{l}3 e n \\
\text { geo }\end{array}$ & $\begin{array}{l}26414 \\
8617\end{array}$ & 42 & Ho & & & & & \\
\hline QDCOF & $\stackrel{-A}{A}$ & jeo & A.28 & 111 & & 116 & & & & \\
\hline ARIOA & $1: 0$ & jen & iil= & iise & & 136 & & & & \\
\hline QAIP & SIA & jen & ili?a & $120=$ & & & & & & \\
\hline ג्र०ण! & $\rightarrow A$ & jeo & $7,3=$ & in & & & & & & \\
\hline $\begin{array}{l}\text { 9902 } \\
\text { G2DA }\end{array}$ & $\begin{array}{l}-A \\
-A\end{array}$ & $\begin{array}{l}\text { sen } \\
\text { sen }\end{array}$ & $\begin{array}{l}74= \\
940\end{array}$ & $i 7 i$ & & & & & & \\
\hline 0202 & 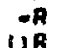 & 300 & $95=$ & & & & & & & \\
\hline $\begin{array}{l}\text { SIED } \\
\text { SIEOT }\end{array}$ & 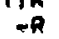 & $161 \mathrm{AD}$ & $\begin{array}{r}\mathrm{GOl} \\
163 \mathrm{PR}\end{array}$ & $\begin{array}{l}1880 \\
1600 \mathrm{AR}\end{array}$ & $\begin{array}{l}260^{\circ} \\
100\end{array}$ & 260 & & & & \\
\hline
\end{tabular}




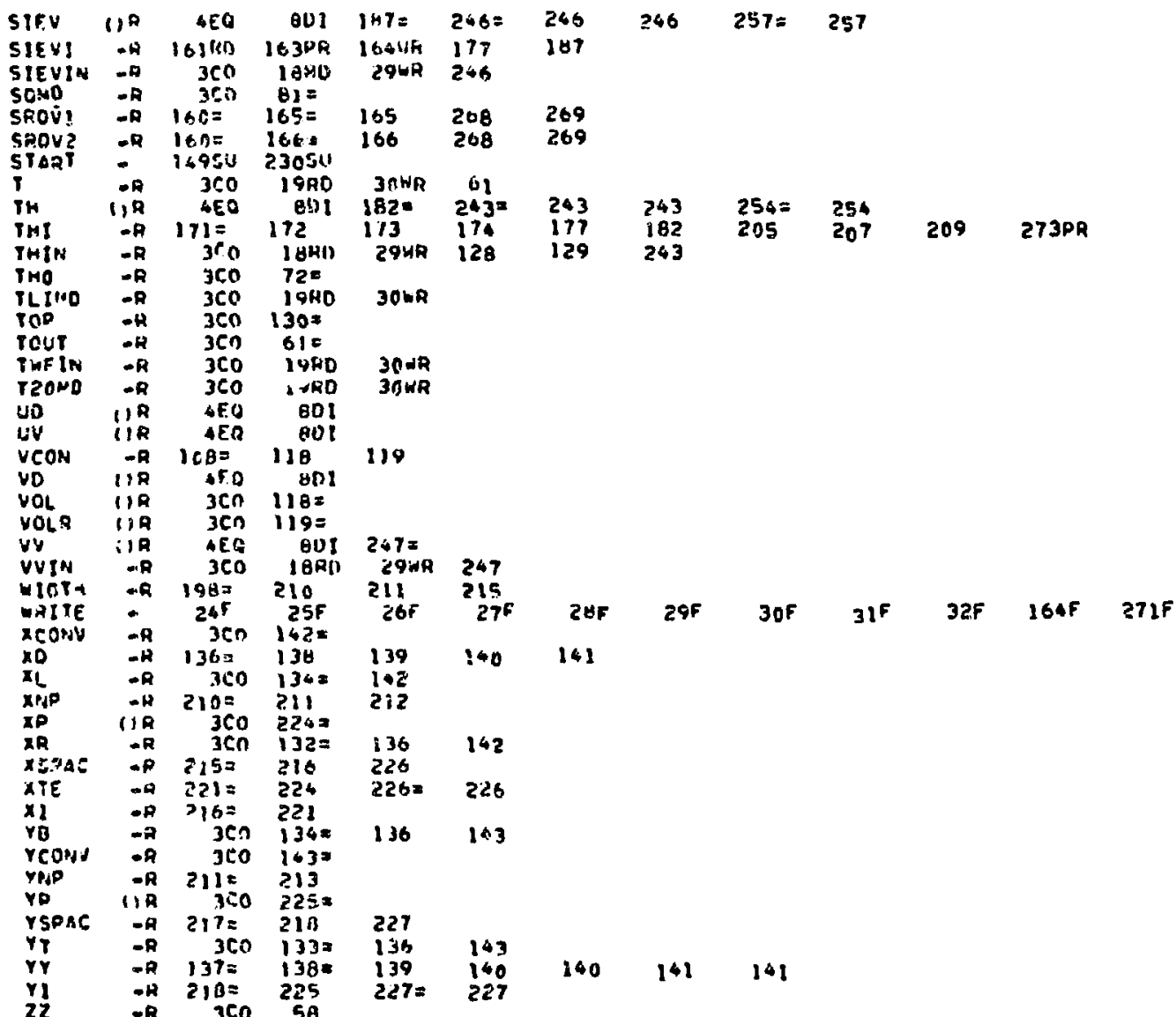


INOEX $01100 / 75$

I

OVERLAY iKACHFIL, Z,OS

INDEX 03/00/75

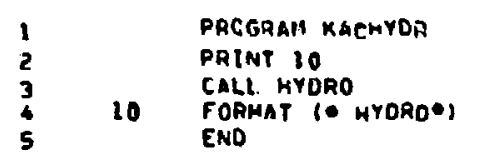

OVERLEY (KACHEIL,2,O)

HogRAM KaChYDa

FOAHAT (० HYORO
PAGE

KACHYOR

2

PAGE 23

KACHYOA

KACHYOR

KACHYDR

KACHYOL

KACHYOR

3
5
5
7
INOEX 01/00/75

SINGEY REFERENCEO VARIABLES

FORHAT - LF HYDRO

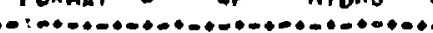

hJLTIPLY-REFERENCEO VAPIAHLES

$10-$ TPA
PROgRaM KaCHYOA

PAGE 
SUAHOUT INE HYORO

CONMON IKSB, ALI (1), ALPOH (9BA)
CUMAON IKSC, AA (1), AASC (2SG76)

KACHYDR

2

(1). AASC (2SG76), AKINF I . AO B BOTOUR, HOTOOZ,

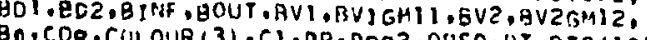

DOC

OZSO,

FIUAR, F X X E IXR FIY

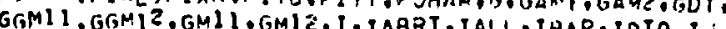

IM. I

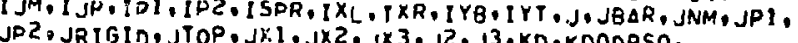
KDUOZ MUSTRO PAANE (B) HCYC NLC OPTOT

NOL. NEZ, NOZZL OHSC ONUMTF NUMRO NUMTD NUNO

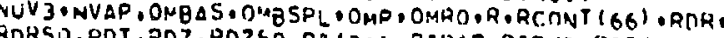

R JHAR PO TOZ HOVP IN

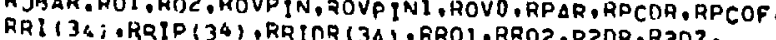

SIEVIN.

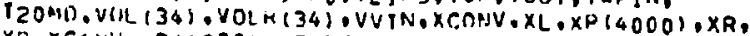

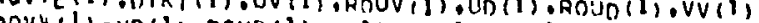

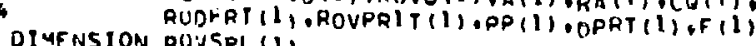
OI MENSION ROUSPL II) IX) (1) IX2 (I)

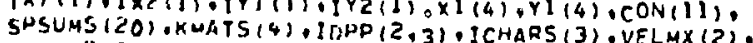

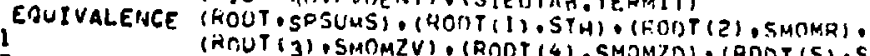

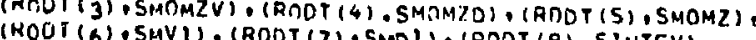 (HOUT (Q), SIPTED). (RODT) SMO SINTE) (RODT SINTEV).

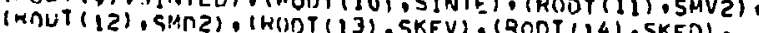 (HOUT (15),SKE). (RODT (16) S SK) (ROOT (I7) SMO)

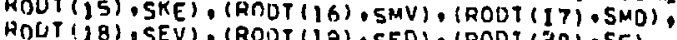


DATA ICHAHS 16416 V VAPOR 
WRITE $(12,3 D P P(1, N T Y P E)$

WRITE $(12,4050)$ JNM,01,CI, NAME I, NCYE

$L=X P(N P), A .3 E$

IF (L.NE, KMAT) GO TO 339

$I X I=F I X L+(X P(N P) 0 D R-X L) \circ X C O N V$

KaChYing

KACHYYR

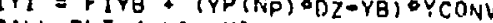

339 CONTINUE

CONTINLE

NFR 2 NFR \& 1

IF ANCYC.LDR.EQ.0 A. NFP.LT.1001 GO IO 310

KACHYOR 149

KACHYDR 151

KACHYDR 152

KACHYDR

KACHYDR 154

KACHYDR 156

KACHYDR 157

KACHYDR 159

KACHYDR 359

KACHYDH 160

KACHYOR 161

KACHYOR 162

KACHYDR 163

KACHYDR 164

KACHYDR $\quad 165$

KACHYDR 166

KACHYDR 167

$\begin{array}{ll}\text { KACHYDR } & 168 \\ \text { KACHYOR } & 169\end{array}$

$\begin{array}{ll}\text { KACHYOR } & 169 \\ \text { KACHYDR } & 170\end{array}$

KACHYDR 170

KACHYDR 171

KACHYDR 172

KACHYOR

KACHYOR

KACHYDR

KACHYDR

KACHYDR

KACHYDR

KACHYDR

KACHYDR

KACHYDR

KACHYOR

KACHYDR

KACHYDR

KACHYDR

KACHYDA

KACHYDR

KACHYDR

KACHYCR

KACHYDE

KACHYYDR

KACHYDR

KACMYDR

KACHYOR

KACHYOR

KACHYDR

2
3
4
5
6
7
8
9
0

DO $619 j=2$. JP

KACHYDR 
110 IF $(K 1+K$. .NE.1) 60 TO 720

IC) $=1$

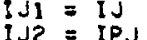

ASSIGN 720 TO KRI 


\begin{tabular}{|c|c|c|c|c|}
\hline 232 & \multicolumn{2}{|r|}{ GO TO 740} & \multicolumn{2}{|l|}{ KACHYDR } \\
\hline \multirow{6}{*}{$\begin{array}{l}237 \\
238 \\
239\end{array}$} & 720 & IF $(K 2+K 4 . N E .1)$ GO TO 730 & KACHYDP. & 255 \\
\hline & & $I C 1=2$ & KACHYDH & \\
\hline & & & KACHYOR & \\
\hline & & 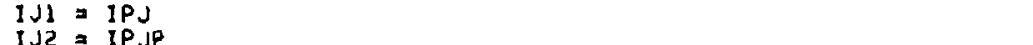 & KACHYDR & \\
\hline & & $\begin{array}{l}\text { IJE }=1 P \text { IP } \\
\text { ASSIGN T30 TO KRI }\end{array}$ & KACHYDA & \\
\hline & & 60 To 740 & $\begin{array}{l}\text { KACHYDR } \\
\text { KACHYDR }\end{array}$ & \\
\hline $\begin{array}{l}240 \\
241\end{array}$ & 730 & IF $(K 3+K 4 . N E .1)$ GO T0 769 & KACHYOR & \\
\hline $\begin{array}{l}241 \\
242 \\
243\end{array}$ & & $\begin{array}{l}I C I=3 \\
I C 2=4\end{array}$ & KACHYDR & \\
\hline 243 & & $\begin{array}{lll}I C 2 & = & 4 \\
I J 1 & =1 . J P\end{array}$ & KACKYDR & \\
\hline 244 & & $\begin{array}{lll}I 7 S & =I P J F\end{array}$ & $\begin{array}{l}\text { KACHYOK } \\
\text { KACHYOR }\end{array}$ & \\
\hline $\begin{array}{l}245 \\
246\end{array}$ & & ASSIGN 769 TO KHI & KGCHYDR & \\
\hline $\begin{array}{l}246 \\
247\end{array}$ & 740 & 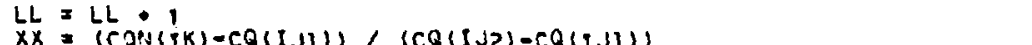 & KACHYDR & \\
\hline $\begin{array}{l}247 \\
248\end{array}$ & & 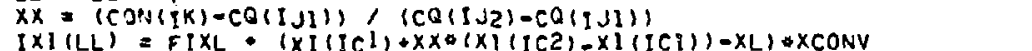 & KACHYDR & \\
\hline $\begin{array}{l}248 \\
249\end{array}$ & & 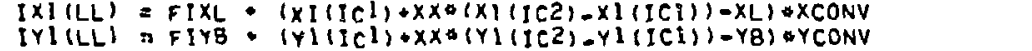 & HYOR & \\
\hline 250 & & IF (LL.LT.2) 60 TO KRI & $\begin{array}{l}\text { KACHYOR } \\
\text { KACHYOR }\end{array}$ & \\
\hline 251 & & CALL DFV $(I \times 1,[Y) \cdot(\times 5 \cdot 1 Y z)$ & KACHYOR & \\
\hline $\begin{array}{l}252 \\
253\end{array}$ & & IF $(I K \cdot E Q \cdot 1)$ CALL PLT $\left\{I x_{1}, I Y 1 ; 35\right)$ & KAC,HYDR & \\
\hline $\begin{array}{l}253 \\
254\end{array}$ & & $\begin{array}{l}I F(I K \cdot E Q \cdot I C-1) \text { CALL PLT }\left(I X_{1}+I Y 1 \cdot 24\right) \\
L L=0\end{array}$ & $\begin{array}{l}\text { KACHYDP } \\
\text { KACHYOR }\end{array}$ & \\
\hline 255 & & IF (IJ2.EO.IFJ) 60 TO 720 & KACHYDR & \\
\hline $\begin{array}{l}256 \\
257\end{array}$ & 769 & 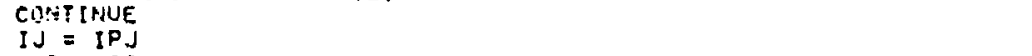 & $\begin{array}{l}\text { KACHYOP } \\
\text { KACHYOR }\end{array}$ & \\
\hline 259 & 779 & $I J P=I P J P$ & KACHYOR & \\
\hline $\begin{array}{l}259 \\
250\end{array}$ & & CALL LODP & KACHIDR & \\
\hline $\begin{array}{l}260 \\
261\end{array}$ & & $I J=I J+N O L$ & KACHYDR & \\
\hline 261 & $\begin{array}{l}789 \\
794\end{array}$ & CONTIGUE & KACHYDR & \\
\hline $\begin{array}{l}26 \overline{2} \\
263\end{array}$ & & $\begin{array}{l}\text { CONTIFUE } \\
\text { ASSIGN } 840 \text { TO KRF }\end{array}$ & KACHYYOR & \\
\hline $\begin{array}{l}263 \\
264\end{array}$ & 800 & $\begin{array}{l}\text { ASSIGN } 840 \text { TO KRF } \\
\text { KRD }=\mathrm{KRF}\end{array}$ & $\begin{array}{l}\text { KACHYDR } \\
\text { KACHYDR }\end{array}$ & \\
\hline 265 & & ASSIGN B89 TO KRFP & KACHYDR & \\
\hline $\begin{array}{l}266 \\
267\end{array}$ & 820 & $\begin{array}{l}\text { GO In } 1830,820,880) \text { LPR } \\
\text { ASSIGN } 88010 \mathrm{KRF}\end{array}$ & KACHYDR & \\
\hline $\begin{array}{l}267 \\
268\end{array}$ & & $\begin{array}{l}\text { ASSIGN } 880 \text { 10 KRF } \\
\text { ASSIGN } 870 \text { 10 KRFP }\end{array}$ & $\begin{array}{l}\text { KACHYDR } \\
\text { KACHYDR }\end{array}$ & \\
\hline 269 & 830 & CALL LINCNT (64) & KACHYDR & \\
\hline $\begin{array}{l}270 \\
271\end{array}$ & & $\begin{array}{l}\text { CALL ADV (1) } \\
\text { GO TO } 860\end{array}$ & $\begin{array}{l}\text { KACHYOR } \\
\text { KACHYDR }\end{array}$ & \\
\hline $\begin{array}{l}271 \\
272\end{array}$ & 840 & $\begin{array}{l}\text { GO } 10860 \\
\text { KRF }=\text { KRFD }\end{array}$ & $\begin{array}{l}\text { KACHYDR } \\
\text { KACHYDR }\end{array}$ & \\
\hline 273 & & ASSIGN OBQ TO KHP & KATHYOR & \\
\hline 274 & & CALL START & KACHYIIR & \\
\hline 275 & & $00899 \mathrm{~J}=1 . \mathrm{NP} 2$ & KACHYDR & \\
\hline 276 & & $008891=1,102$ & KACHYOR & \\
\hline 277 & & $L=I J M=N O$ & KACHYOR & \\
\hline 278 & & GO TO $(850,850,870) L P R$ & KACHYDR & \\
\hline 279 & 850 & WRITE (I2.6090) IOJ.THILI, UVIL) VVIB), SIEVILI, ROVPRI (LI, ROVPRIL), & KACHYDR & \\
\hline & & $\begin{array}{l}\text { OPRT }(L), P(L), E(L), U D(L), V O(L), S I E O(L), R O D P R I(L) \\
R O D P(L), A(L), K I J(L)\end{array}$ & $\begin{array}{l}\text { KACHYDR } \\
\text { KACHYDR }\end{array}$ & \\
\hline $2 \theta_{0}$ & & LINESF $=$ LINFSF +3 & KACHYOA & \\
\hline 281 & & (LINESF.LT.59) GO TO KAF & KACHYOA & \\
\hline 282 & 860 & CALL AUV (1) & KACHYDR & \\
\hline 253 & & $F=0$ & KACHYDR & \\
\hline 284 & & WRITE $(12, \Delta 050) \quad J N M, 01, C_{1}, N A M E$, T, NEYC & KACHYOA & \\
\hline 285 & & WRITE $(12.0100)$ & KACHYDR & \\
\hline
\end{tabular}



LINESP = LINESP *

880 IF (LINESP.LT.54) GO TO KRP PRINT 4110

LINESP $=0$

PRINT 4050, JNM,OI,CI, NAME, T,NCYC PRINT 4100

889 GO TO KRP

CAL $=I J M$. NO

CALL LOOP

899 IJM $=1 \mathrm{JM}=\mathrm{NO} 2 \mathrm{~L}$

900 DO $909 \quad I=1,20$
900 SPSUMS(I) $=0$

CALL START

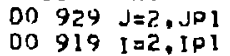

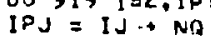

IMJ $=1 \mathrm{H}-\mathrm{NO}$

ROUVRL = ROVPR(IJ) SVOLII)

ROUVOL I ROOPR IIJ) OVOL(I)

STH $=$ STH $+\{1,-T H(I J))$ SOL(I)

SMVI = SMVI * VOL

- ROVPRI (IJ)

SHVE = SHVZ $V$ VOL (I) $0\left(R O V P R(I J)-R O V P R_{1}(I J !)\right.$

SMDZ = SMUZ: YOL (I) RODFRIIIJ)

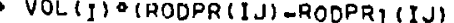
-UD (IJ) O (RODPR IIJ)・RODPR (IPJ))

KACHYOR

KAEHYDR

KACHYD?

KACHYOR

KACHYDR

KACHYDR

KACHYDR

KACHYDR

KACHYDR

KACHYOR

KACHYDR

KACTYUR

KACHYOR

KACHYDA

KACHYDR

KACHYOR

KACHYDR

KACHYDA

KACHYOA

KACHYSR

KACHYOR

KACHYOR

KACHYDR

KACHYDR:

KACHYOR

KACAYDR

KACKYOR

KACHYOR

KACHYOR

KACHYDR

KACHYOR

KACHYOR

KACHYDR

KACHYDR

KACHYDR

KACHYDR

KACHYOR

KACHYOR

KACHYOR

KACHYDR

KACHYDR

SKEV = SKEV STKEV $+V O(I J) 002+V D(I J M) * * 2)$

SKE = SKED STKEV . STKED

STEV = STIEV+ STKEV

KACHYDR

STED = STIED . STKED

KACHYOR

KACHYOR

SEV = SEV * STEV

$S E=S E$ STEV - STEO

$I_{J M}=I_{J M}$ J NO

KACHYDA

KACHYDP

KACHYDR

KACHYDR 
IF (LPR.GT.0) WRITE $(12,4130)$ T,NCYC, (SPSUMS(L),L $=1,20)$

KACHYOR 366 IF (LPR,GE, 2$)$ PRINT AIJO

T, NCYC, ISPSUMS $(L, i, L=1.201$

KACHYOQ

KACHYOR 369 GO TO KROU

1000

CALL START

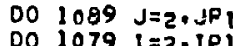

DO $1079 \quad I=2,1 P I$

IPJ $=I J \cdot N Q$

IMJ $=I J=N O$

XIVL $=$ RDIODR UVI (IHJ) + SIGN(AO,UV(IMJ))

HPXIVL $=.5 * X I V L$

HMXIVL $=.5 \cdot X . I V L$

XIVR = BDTODR०UV(IJ) - SIGN(AO,UVIIJ)

HMXIVR $=.5$ - XIVA

HMXIVR $=.5-X I V A$

XIVB $=$ BDIODZ*VV(IJM) - SIGN(AO,VV(IJM)

HMX IVB $=0.5+x ! V$

XIVT $=00150 z$ XIV

MPXT = BOTODZ"VV(IJ) - SIGN(AO,VV(IJ))

HMXIVT $=.5 \cdot X I V T$

XIDL $=B D I O D R+U D(I M J)+\operatorname{SIGN(AO,NO(IMJ))}$

HMXIDL,

$X I D R=B O T O D Q=U D(I))$ SIGN $(A O, U D(1) I)$

HFXIOR $=05 \times I O Q$

HMXIDR $=.5-X I D R$

$X I 08=$ GDTODZ $* V D(I J M)$ SIGH $(A 0, V D I I J M) 1$

HPXIDB $=-5+X I D G$

HMXIOB $=.5 \div \times 108$

$X I O T=B 0100 Z * V D(I J)$ SIGN(AO.VOIIJ)

HPXIOT $=.5+X I O T$

UVRe UVis $-x$ xid

UVRL $=$ UVIIMJ) ARIP(II-1)

UORA G UD(TJ) ORIP(I)

UDRL $=U D(I M J) \backsim R I P(I-1)$

RH $=$ THIJU

RR $=1$, ROVPRIIJ,

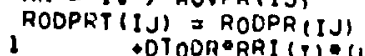

3
2

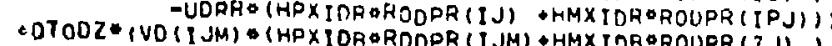
-VO(IJ): (HPXIOTORDOPR (IJM) \&HMXIORBROUPR (IJ)

379 RODPRIT E ROOPRIIIJ)

1 ODTODOCRT (I)

-DTODR*RRI (1) -OTOOZ

THTE I.VDIJ) (HPXIDTOROUPRI (IJ) *HMXIOTQROOHRI (IJP)

IF (THTE TT THOPITQRHOI - (RODPRT (IJ) -RTDPRIT) \&RROZ

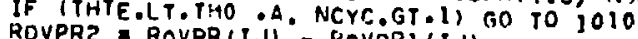

$1^{A(I J)}=$ SIEVIIJ) (ROVPRI (IJ) IRVIGMII + ROVPRZQRVZGMIZ)

$$
\text { "THTE* (ROVPRIIIJIABVI + ROVDRz"AVI)) }
$$


$V E L=.25 \cdot(U V(I J) * 2+U V(I M J) \otimes 2 \cdot V V(I J) 002 \cdot V V(I J M) * 2)$

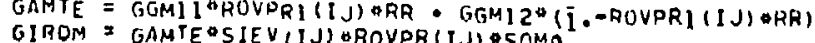

1020 A IIJVC $=$ KIJIIJ) = AKINFI

1020 SIEVC $=$ SIEV(IJ)

TVC = SIEVC $\triangle$ ROVPR(T)

1 TVC = SIEVC PROVPR(TJ)

${ }^{1} T V H=$ SIEV (ROVPRI IMJ) QBVI * (ROVPR(IMU))-ROVPHI (IMJ))-QVZ)

1 TVB = SIEV IROVPRI (IPJ)ABVI.

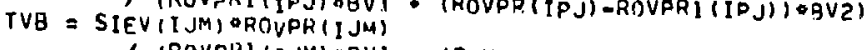

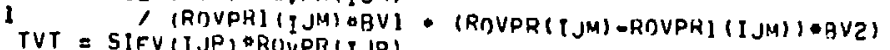

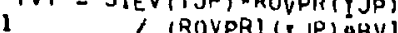

404

$\triangle 05$

406

407

409

.09

610

412

413

415

TOR = SIED (RODPR] (IMJ) OBDI + (ROOPR(IMJ)-RODPRI (JMJ) IOBD2)

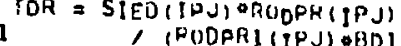

TOQ = SIED 1 T.JM) POOPRR (TJM)

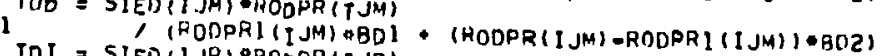

${ }_{1}$ TOT = SIED (IJP) ORODPR (IJP)

THLB $=.5$ (ROOPR! (I JP) OAOL * (HODPR (I JP)-RODPR! (I JP) THLB = 5.5 (THIJ. TH(IMJ)

THRB $=1$ - THLB

OMTH = $=$ : TTHIJ. TH(IOJ)

THBO $=5:$ ITHIJ

OITHOB $=2$ - TTHIJ. TH(IJM)

THTQ = $5:$ TTHIJ.

OMTHIO $=$ ThIJ. TH(T.JP)

CFXL = UVRL : (HPXIVL SIEVIIMJ) *HMXIVLOSIEVC)

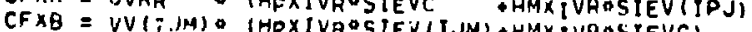

CFXT = VV(TI). IHPXIVTSIEVC

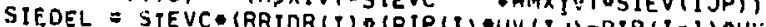

423
424
425

$\begin{array}{lll} & \\ & \text { RDZAI }\end{array}$

IF (THTE.LT. THO) GO TO 1030

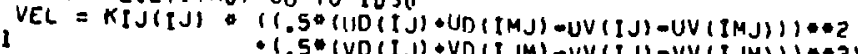

426

PTE = P(IJ)ORR (RRIOR(I)*(HIP(I)*(THRB*IJVIIJ) +OMTHRB*UD(IJ)

KACHYDH 425

KACHYOR 426

KACHYIDR 428

KACHYDR 430

KACHYDR 431

KACHYOR 432

KACHYDR 433

KACHYDR 434

KACHYDR 435

$\begin{array}{ll}\text { KACHYDR } & 436 \\ \text { KACHYDR } & 437\end{array}$

KACHYDR 438

KACHYUR 439

KACHYDR 440

KACHYOR 441
KACHYDR

KACHYOR 443

KACHYOR 444

$\begin{array}{ll}\text { KACHYDR } & 445 \\ \text { KACHYDR } & 446\end{array}$

KACHYDR 447

KACHYDR 445

KACHYDR 449

KACHYDR 451

KACHYDR 452

KACHYDR 454

KACHYOR 455

KACHYDR 456

KACHYDR 457

KACHYDR 450

KACHYIIR 459

KACHYDR 460

KACHYOR 461

KACHYDR 463

KACHYOR 464

KACHYOH 465

KACHYDR 466

KACHYOH 467

KACHYOR 468

KACHYIIR 469

KACHYDR 470

KACHYDR 471

KACHYOR 472

KACHYDR 473

KACHYDR 474

KACHYDR $\$ 75$

KACHYDR 476 

-RDZO ITHTBOVV IIJ) OOMTHTBOVDIIJI

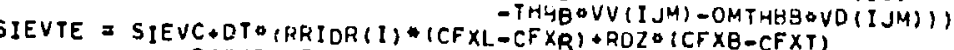
5 -RRI (I) OKVODRSOL (THRBaRIPII)

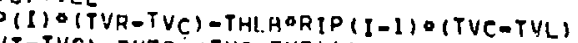

KACHYDR

KACHYDR IF (A (IJ).NE.AKINF () A(IJ) = A(IJ) OSIEVTE/SIEVC

$C F X L=$ UDRL $\because$ (HPXIOL $\$ S I E D(I M J)+H M X I O L$ \&IFDC)

CFXR = UDRR : (HPXIOROSIEDT +HMXIDROSIFD(IPJ))

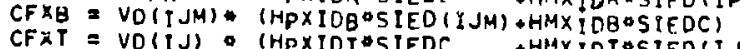

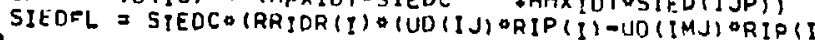

KACHYCR

KAC.HYI:A

KACHYDR

KACHYOR

KACHYDR

KACHYDR

SIEUTE = SIEDC.DTO $\quad$ ROZO (VU (IJ) $\quad$-VDIJJM)

$$
\text { 1) }
$$

$\therefore 1$. RODPR (IJ) \& (RO (TVC-TDC) + E (I) (CFXB-CFXT)

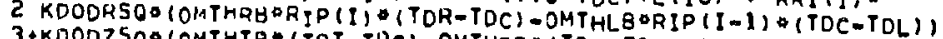

3.KDODZSO० (OMTHTE*(TOT-TDC)-OMTHBQ (TDC-TDB)) + SIEDEL)

IF (I.GT.2) gO TO 1040

TH(IMJ) = THTE

RODPRI (IMJ) = RODPRIT

$P(I M J)=P(I J)$

KIJI!MJJ) $x \operatorname{KIJ}(I J)$

SIEV (IMJ) $=$ SIEVTE

1040 IF (J.GT.2) GO TO 1050

TH(I JM) = THTE + BINFO (THIN-THYE

RODPRI (IJM) = ROOPRIT

P(THA) $=P(I J)$

SIEVIIJH) = SIEVTE * BINF*(SIEVIN.SIEVTE)

SIEO (IJM) : SIEDTE

1050

GO 10 10BO

TH(IJM) $=T H T A B(I)$

RODPRI (IJM) = RODITAB II

SIEV (IJM) $=$ SIEVIAB (I)

1060 THTAB (I) = SHIE

RODITAB (I) = FOUPRIT

SIEVTAB (I) = SIEVTE

SIEOTABIII) = SIEOTE

IJ $=$ IPJ

1079 IJM $=$ IJM $+N Q$

THIIJ) ITHTE

RODPQ $1(I J)=$ ROUPR $_{1} T$

$P(I J)=P(I J-N O)$

KIJIIJ) $=K I J(I J-N Q)$

SIFV(IJ) = SIEVTE

1089

SIED (IJ) = SIEDTE

DO $1092 I=2 \cdot I P^{2}$

TH(JM) $=T H(I J)=T H T A B(I)$

PODPRI (IJM) E ROUPRI(IJ) ROOITAB(I)

$P(I J)=P(T J M)$

KACHYDR

KACHYDR

KACHYDR

KACHYOR

KACHYDR

KACHYOP

KACHYDR

KACHYOR

KACHYDR

KACHYDR

KACHYDR

KACHYDR

KACHYDP

KACHYDP

KACHYDR

KACHYDR

KACHYDR

KACHYOR

KACHYDR

KACHYOR

KACHYOP

KACHYDR

KACHYDR

KACHYDR

KACHYOR

KACHYOR

KACHYDQ

KACHYDR

KACHYR

KACHYOA

KACHYOR

KACHYDR

KACHYOR

KACHYDE

KACHYUR

KACHYOR

KACHYDR

KACHYDR

KACHYOR
KACHYOR 
1099

SIEV(IJH) = SlEV(IJ) = SIEVTAB(I) SIEO(IJM) = StED(IJ) = SIEOTAB(t)

KACHYDQ

KACHYOA

KACHYOR
KACHYDA $J M=1 \mathrm{JM} N \mathrm{NO}$

CALL NONE

1500 IF IIBAR.EO.1广 GO TO 1550

CALL START

00 is49 $J=2$. JP

$001539 \quad i=2.16 A R^{2}$

IJA $=$ KREO - IJ

I JPA = KAEO : IJP

IJMA = KREO O TJM

IMJA $=1, J A=$ MD

PPJPA E IJPA - NO

IPJPA = TJML NG

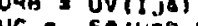

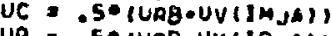

HOULO

HOUP

QOUAB

RTAC

WHac : So

Whac :

(a)

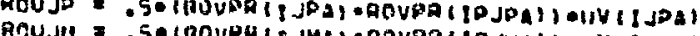

IIC gOTOQUEU !

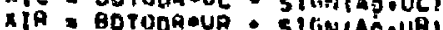

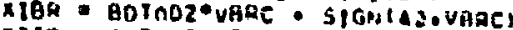

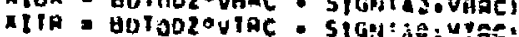

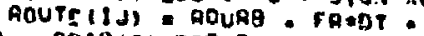

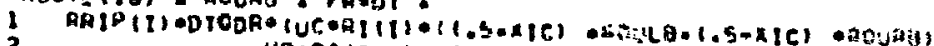

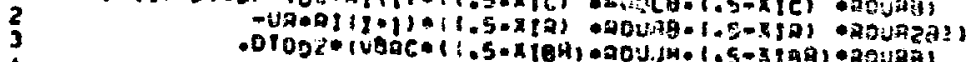

ij. IJ 150

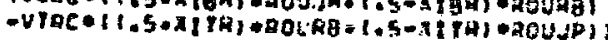

KACHYRA

ACHrDF

rachror

KACHYUA

KACHYDR

racoros

KACHYOA

RACirsa

xacurog

racuros

cecron

cacingos

cocition

raciurat

recures

vaciras

reckyat

xacuras

recurya

RACriso

racerote

activis

acivn

mentise

acmor

xacupat

aEenvô

actirgin

netures

xicuron

GaCurga

Kafheras

acuras

nerwhat

Mánes

acturia

asinter

MATESG

uatertan

Maesure

crive

Mactorga

sectinta

recciva

taceren

raevró

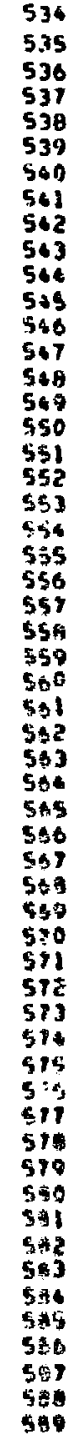




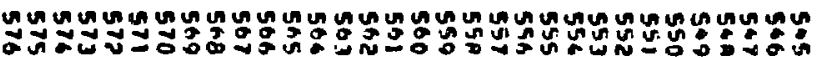

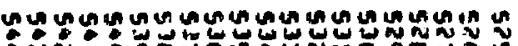

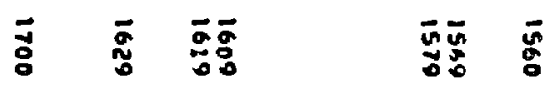

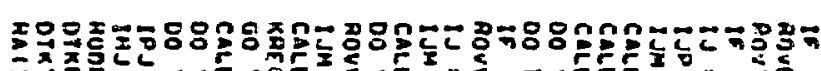

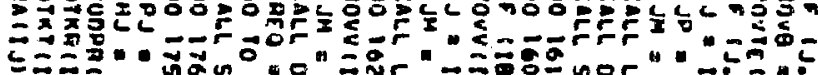

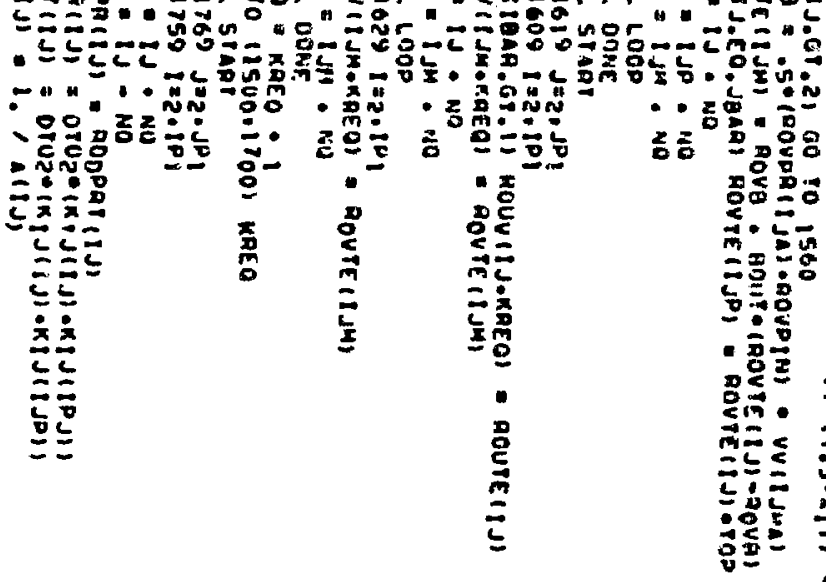

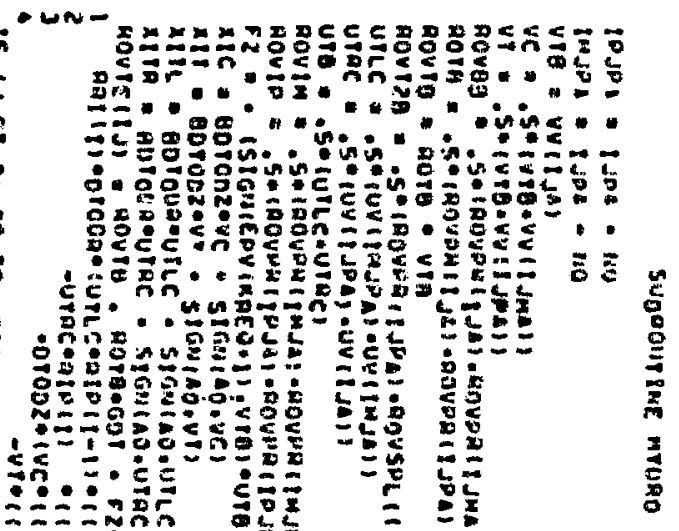

$\pm 0$

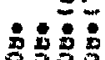

象象里

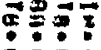

ininis

in

政要

站音

武重星

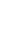

.




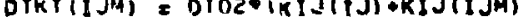

1720 IF (I.LT. IOI) GO TO 1730 RODPRIISJ) = RDOPR IIJ) ROVPAT (IPJ) = ROVPR(IPJ)

173D IF (JoLT, JPI) GO 101740 RODPR (IJP) $=$ RODPR $(1 \mathrm{I})$

174 f $I J=I P J$ ROVPRIIJPI

IJH= = iJP : NO

1769 CALL LOOP

Call VONE.

CALL START

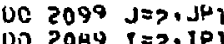

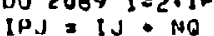

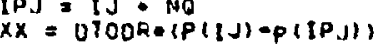

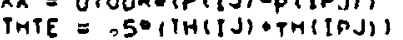

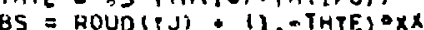

$C S=$ HOUV (TJ) : TMTE*XX

ROVTEH $=.5$ (ROVPR (IJ) ROVPR (IPJ))

RODTEM $=.5 \circ$ (ROUPA (IJ) CRODPH (JPJ)

OTK = OTKR(1J)

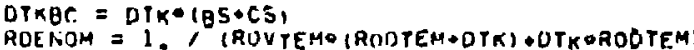

UV $(I J)=$ ROENOMO (HODTE YOCS +1$) T K A C)$

$2099 \quad l J=18 \mathrm{~J}$

NOH (ROVTEM・BS•OTKBC)

2099 CALL LOU

CAILL OONE

CALL START

KMEO =

DO $2199 \mathrm{j}=2 \cdot$. JTOP

DO $2189 I=2 \cdot I P I$

$K K=0100 z-(P(t) J M)-P(t))$

THTE
DS $=$ ROVD $(T H Y):(1),-T H T E)=X X$

DS = ROVD (THU) (1)

ES = ROVVIIJM) . THTEQXX

RODTEM =

DTK

DTKOE OTKITIJMS

RUENOM $=1$ (RUVTEM (RODTEM+DTK) +DTKERQUTEM)

VVIIJM) = DOENOYO (ROIUTEMEES + OTKOE)

YD (I JP) $\times$ RDENOMO (ARVTEHODS ODTKOE)

$G O$ iO $(2130.2140)$ KREO

$2130 \mathrm{VV}\left(T^{\prime} J M\right)=$ gCUTOVV IIJM) + VVIN

VU(IJM) GOUTOVO (IJM)

KACHYSR

KACHYOA

KACHYDA

KaChYIS

KaCHYDH

KACHYOA

KACHYOR

KACHYOR

KACHYOR

KACHYDR

KACHYOR

KACHYOP

KACHYDQ

KACHYA

KACYYOA

KACHYDR

KaCHYDR

KACHYOR

KACHYDR

KaCHYOR

KACHYOR

KaCHYOH

KACHYDR

KACHYYA

KACHYOA

KACHYOR

KACHYOR

KACHYDR

KACHYOR

KACHYDO

KACHYOR

KACIIYOR

KACHYDR

KACHYOA

KACHYOR

KACHYDR

KACHYOR

KACHYDA

KACHYOR

KACHYOR

KACHYUR

KACHYDR

KACHYDR

KACHYOR

666
647
648
549
650
651
652
653
654
655
656
657
658
659
660
661
662
663
654
665
666
667
658
669
670
671
672
673
674
675
676
677
578
679
680
681
682
683
684
695
646
687
6818
689
690
691
692
693
694
695
696
697
698
699
700
701


2140 IJ $=1 \mathrm{IJ}$. NO

KACHYDR

2189 I IM $=1 \mathrm{JM} \cdot \mathrm{NO}$

2199 CALL LOOP

CALL DONE

CONV $=0$.

CALL START

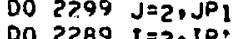

KACHYDR

KACHYOP

KACHYOP

KACHYOP

KACHYOR

KACHYOR

KACHYOR $I M J=I J-N O$

IPJ $=1 \mathrm{~J}+\mathrm{NO}^{\circ}$

RCA $=$ ISARAIIJ

UVR $=$ UV UV IIU

UVI = UVIIMIJ

VVB = VV(I

IF (I.EQ.Z) GO TO 2210

KACHYOR

KACHYDR
KACHYOR

KACHYDR

KACHYUR

KACHYDP

KACHYDR

KACHYOR

KACHYOR

KACHYOR

PUDENL I PUDENR

TERMIL D TERHIH

GD TO 2220

2210 OTK = OTKR (IMJ)

THTEL $=.50(T H(I)$ IT) THITMJII

ROVL $=.5^{2}$ (ROVPRII)) ROVPR (IMJ)

RODL $=.5^{\circ}$ (ROOPR (IJ) RODPR (IMJ)

PUDENL $=1 . /(R O V L+(R O D L+O T K)+D T K \triangle R O D L)$

TERMIL = HOVL II.-THTEL) OOTOUR

2220 TEAMTL 2 THTELODTOUR

TH (J.E.G, 2 , तO TO 2230

THTEO = THTETII)

PVDENB = PUDENTIII

PVOENB = PVDENTII

TERMZB = TERMLTII)

GO TO 2240

2230 OTK = OTKT11 $\mathrm{JN}$

THTEB $=.501$ TH(IJ).TH(I.JM))

HOVB $=.50$ (ROVPR (IJ) + HOVPR (IJM)

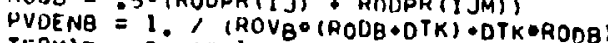

TERIA) $=$ ROVB*I (1.-THTEB) OOTUDZ

2240 DTK = UTKR IITH

UTODZ

THTEA = .5 $(T H(I J)$. TH(TPJ)

ROVR =

RODR $=501$ ROOPR (IJ) ROOPH (IOJ)

PUDENR $=1$. , (ROVR (ROOR・OTK) DTK*ROAR)

TERHIR = PRVQZ11.-THTERIOOTDOR

TERMZH = THTER・DTODR

DTK $x$ DTKT (IJ)

THIET(I):

ADVT $=.5 *$ ROVPR (IJ) PROVER(I)P

ROOT(I) = 5* (RODPR (IJ) PROCPR(I)

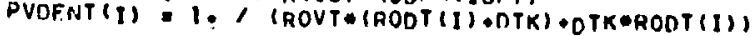

KACHYIRR

KAC

KACHYTII

KACHYTH

KACHYDP

KACHYDR

KACHYOP

KACHYOR

KACHYDR

KACHYDR

KACHYDR

KACHYOR

KACHYDR

KACHYDH

KACHYOR

KACHYOR 
KACHYOR
KACHYOR OMBETA IIJ) O OMP I HBETA

697
698
699
700
701
702
$70 ?$
70
784
705
706
707
708
709
710
711
712
713
714
715
716
717
718
719
720
721
722
723
724

Go TO 2270

2250 OHBETATIJ) = OMBSPL - PODPA (IJ)

CONV = AMAXI (CONV * (RZORO (ABS (UVR) + ABS (UVL))

IJ $=I P J$

•R2OZ*(ABS (VVT)•ABS (VVB)II):ROVPR (IJ))

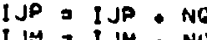

22319 IJM J IJM.

2299 CALL LOOP

CONV $=$ EPS $=(C O N V \cdot E M G)$

COLS = EPS

MUSTIT $a$

2400 CALL STADT

DO $2490 \mathrm{~J}=2 . \mathrm{JP}$

DO $2489 \quad I=2, I P$

$1 \mathrm{PJ}=1 \mathrm{~J}=\mathrm{J}=\mathrm{H}$

IF ITH(IJ).LT.THO) GO TO 2450

UVRB = UVITS)

UVLA = UV(TAJ)

VVIB $=$ VV(IJ)

VVEB $=$ VV \{IJMT

XIVR = BUTOO4.UVHB - SIGN(AO.UVRB)

XIVL = EDTODQUUVLB : SIFNIAOSUVLE)

XIVT = BOTODZOVVTB: STGN(AO,VVTB)

$X I V B=B D T O D Z \cdot V V B B$ - SIGN(AO,VVBB)

ROVPATC E DOVLATII

VTIL = ROT-(HOVPRIC-HOVPA (IJ)) + RRIDR(I)

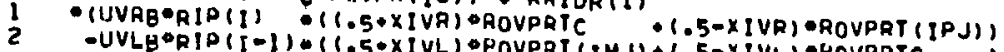

- RUZ - (VVIB: $11.5 \cdot x$ IVT) HOVPRTC $\$(.5-x$ IVI) HOVPRTC GN TO 2470

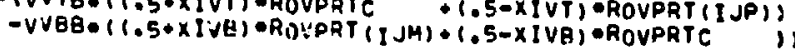

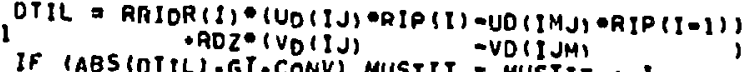

727

2470 PP(IJ) = P(tJ) O DTILOOHBETA IJ

$$
\text { IJ }=10 J
$$

5089 IJP $=1 \mathrm{JM}$. NO

2489 IJP $=1 \mathrm{JP}$. NO

CALL DONE

CALL STAHT

DO $2599 \mathrm{~J}=2$. JP

$2589 I=2 \cdot I P$ 


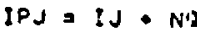

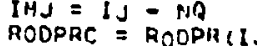

ROOPRC $=$ ROOPIR (IJ)
THIEC $=$ TH(1/J)

THIEC $=$ TH
$P C=P(I)$

$P P C=P(I J)=P P(I)$

OPRTIIJ) $=O P C=P P C-P C$

ROVPRTN = ROVPATIJ

If (1) IF $(1, G T, 2)$
HIIMJ) $=$ PPC

ROVPRT (IMJ) $=$ ROVPRTN

OPR = PP IIPJ) - P (IPJ)

OPR $=$ PP (IPJ) - P (IPJ)
OPDIODR = IDPC-UPR) ODTOOR

THRB = .50 (THTEC+TH(IPJ))

UVIE $=$ UV(IJ)

DTK = DTKR J

OTKDU = OTKO CUVTE-UDTEI

ROVRBO =

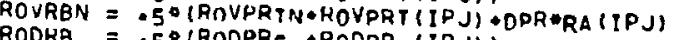

RS = ROYRBOOUVTE UIKOU OPOTORAR

RUENOM =

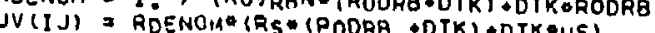

UD (IJ) = ROENUM* ('JS (KOVRAN*OTK) OOTKORS)

2530 GOP 2540

P(TPJ) $=$ PPC

3 RUVPRTA

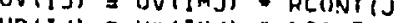

2540 IF (IJ) N ND (IMJ) ACONT(J)

DPI = PP II IPI G

DPOTODZ 2 TDPC $-U P T$ T

THIB $=.50$ (THTEC+TH(IJP))

VDTE = VDITUI

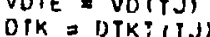

UTKDV = DiK (VVTE-VOTE.)

ROVTBO $=.5 \%\left(H_{0}\right.$ VPRTT)+ROVPRT $\left.(1 . J P)\right)$

ROCIR $=.5 \%$ IAUVRTHAROVPATIIITP

SS = ROVTBOOVVTE OTKDV DPDTODZOT

VS = ROUTE OVOTE - OTKOV DPTTODZ OTHTE

RDENOM $=$ ) (HOVTONO (RODTBDTK)

$V V(I J)=$ ROENJMO (STO (RODTB ODTK) ODRKROOTB)

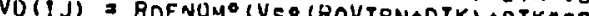

IF (J.GT.?. GO TO 2580

$P(I J M)=P P C$

HOVPRT (I JM) : RUVPRTN - EINFA(HOVPIN-ROVPRTN)

$V V(I J H)=B O U T S V V(I, J) \cdot V V I N$

VD(IJM) = BOUT VO (IJ)

2560 PIIJPS 2 PPC

KACHYDP

KACHYDP

KACHYOR

KACHYDR

KACHYOR

KACHYUR

KACHYOR

KACHYDA

KACHYDR

KACHYDR

KACHYDR

KACHYOR

KACHYOS

KACHYDA

KACHYOR

KACHYOP

KACHYOR

KACHYDR

KACHYOR

KACHYDR

KACHYDR

KACHYD

KACHYDR

KACHYDR

KACHYDR

KACHYDP

KACHYDR

KACHYOR

KACAYOR

KACHYNR

KACHYOR

KACHYOY

KACHYDR

KACHYDR

KACHYOR

KACHYOR

KACHYUR

KACHYOR

KaCHYOR

KACHYOR

KACHYOR

KACHYOR

KACHYDR

KACHYDR

KACHYDA

KACHYOR

KACHYOR

KACHYOR

KACHYDR

KACHYDR

KACHYOR

KACHYDR

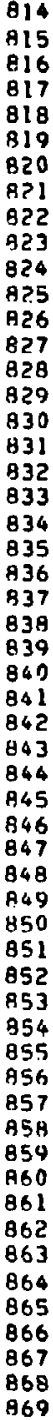




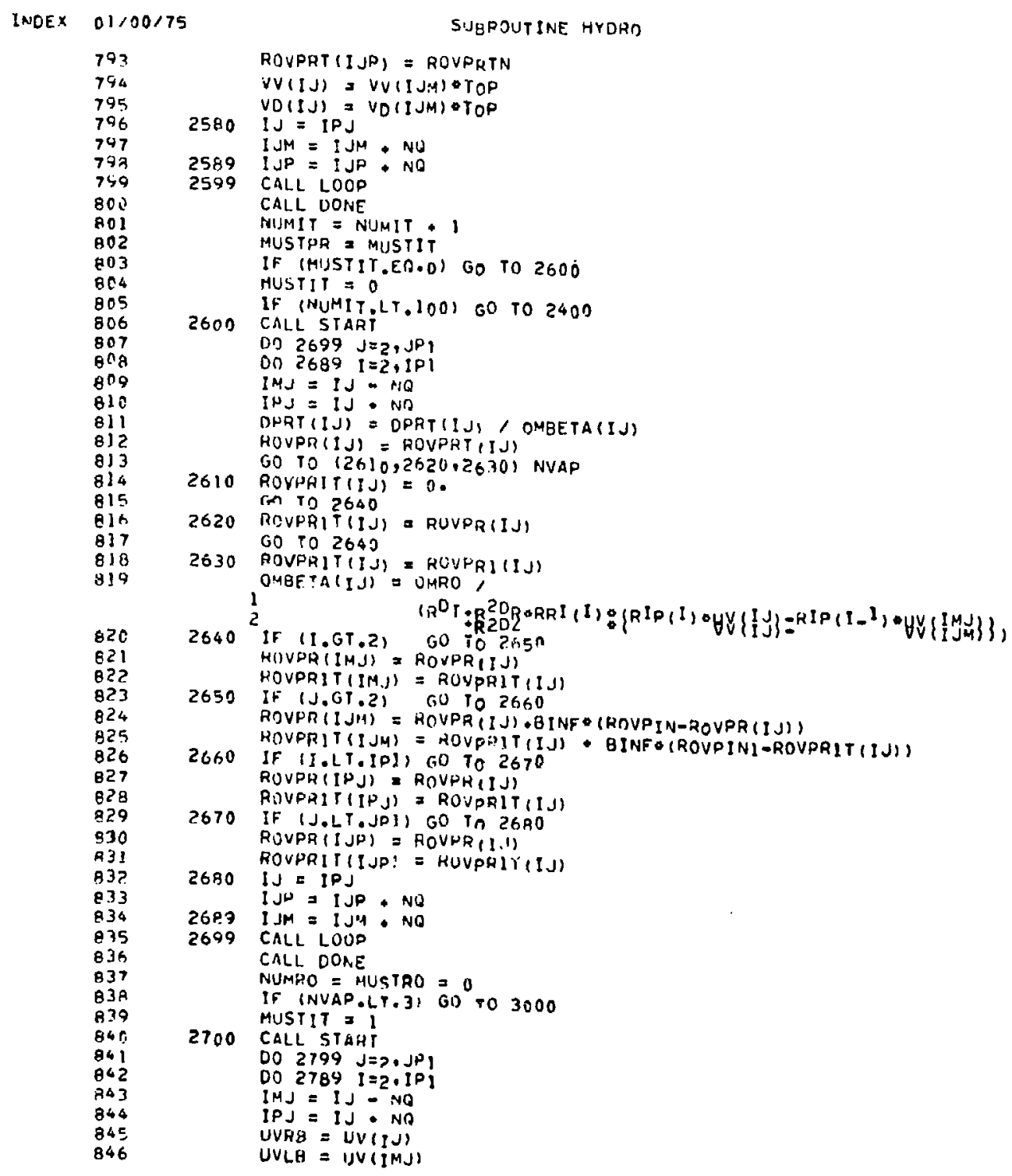

PAGE 41

KACHYDR

KACHYDR

KACHYDF

KACHYOR 873

KACHYDP 874

KACHYDR 875

KACHYDR 876

$\begin{array}{ll}\text { KACHYODR } & 877 \\ \text { KACHYDR } & 878\end{array}$

$\begin{array}{ll}\text { KACHYYOR } & 878 \\ \text { KACHYDD } & 879\end{array}$

$\begin{array}{ll}\text { KACHYDR } & 879 \\ \text { KACHYDR } & 890\end{array}$

KACHYDR 890
KACHYDR

KACHYDR B8I

$\begin{array}{ll}\text { KACHYOR } & \text { BA2 } \\ \text { KACHYDR } & B B 3\end{array}$

KACHYDR

KACHYYR

KACHYDR

KACHYDR

KACHYDR

KACHYDR

KACHYOR

KACHYDR

KACHYDR

KACHYDH

KACHYDA

KACHYDR

KACHYDP

KACHYDOR

KACHYDR

KACHYDR

KACHYDR

KACHYDR

KACHYDR

KACHYOR

KACHYDR

KACHYDR

KACHYD

KACHYDR

KACHYDR

KACHYOR

KACHYOR

KACAYOR

KACHYIR

KACHYDA

KACHYOP

KACHYDP

KACHYUR

KACHYDR

KACMYOA

KACMYDR

KACHYDR

KACAYOR 
VVIB $=V V(I J)$

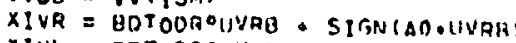

VIECHYOIR

KACHYOR

XIVT $=$ BOTODZ VUIA: SISNIAO.UVTH

KACHYi)

KIVA = BOT COZ UVBBA: SISN(AO,VVGB)

$Q=$ ROTE (HOVPRTO-KOVPRI (IJ)) R RIDRI)

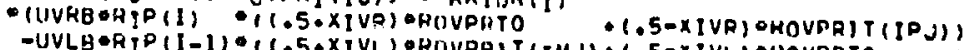

KACiYYDR

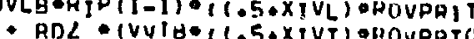

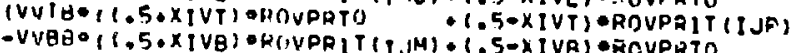

KACHYDH

HF (AB5 (Q) GT OCONV HUSPIT = MUSTIT

KACIYYOR HOVPATN = ROVPRIT IIJI = KOVPRTO = OMGETA (IJ)

IF (I.EO.2) ROVPRITIIMJ) = ROVPRIN

IF (J.EO.2) RIUPRITIMJ) = ROVPPTN

BINF * \{RDVPINI-ROVPRTNI

KACHYTR

Y.ACHYBA

KACHYOC

KACHYDR

KACHYDR

KACHY!SR

$I J=I P J$

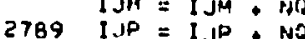

CALL LOOP

CALL DONE

NUMRO = NIJMRO *

MIJSTRO J MUSTIT

IF (MUSTIY.EO.O) GO TO 300 OO

MUSTIT $\approx 0$

3000

IF (NIJMRO.LT.100) 60 TO 2700

KACHYOR

KACHYOIN

KACHYOR

KACHYMR

KACHYOR

KACWYOR

KACHYDR

KachYoR

KACHYDQ

KACHYIDP

KACHYIJP

ITKKKL = UTKR(1J-hO)

$E(I J-N J)=0$.

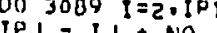

$I M J=I J-M Q$

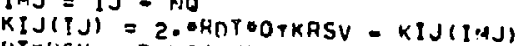

UTKHSV = DTKR(IJ)

$A(I J)=10$ RA

$E(I J)=0$.

ROVPRI (I)

IF (I.EOL = ROVPRITIIJ)

IF (I.EO.2) RUVHRIIIMJ) = HOVPRIIIJ

IF (I.EO RUVPHI (I.JM) = ROVPRIIIJ

(JEOID) ROVPRI (IPI) = ROVPRIIIJ

IF.JPI) R(IVPRI IIJP) = ROVPRI IJ

$30891 \mathrm{JM}=1 \mathrm{JM}$. NO

3099 CALL LOOP

CALL DONE

IF (NPTOT.EQ.0) GO TO 100

CALL START

KACHYOR

KACMYUA

KACHYOA

KACHYOA

KACHYUH

KAC:YYIISH

KACWYOR

KACHYOA

KaCHYSP

BINF*|ROVPINI-ROVPRI(IJ)

KACHYOR

KACHYUR
KACHYOR

KACHYDR

KACHYDR

KACHYD,R
KACHYOR

KACHYOR

KACMYUR

KACHYDR

KACHYDR

KACHYIR

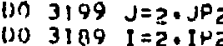

IF (I.GT.S) GO TO 3110

$\begin{aligned} V V(I J M-N O) & =V V(I J M) \\ V D(I J M-N Q) & =V D(I J M)\end{aligned}$ 
9524070 FORMAT 100 RESTARTINSF FROM TDः13

4020 FORMAT $13 \times 08410^{\circ} T=0$ PEI2,5\% CYCLE=015I KACHYDR 1038

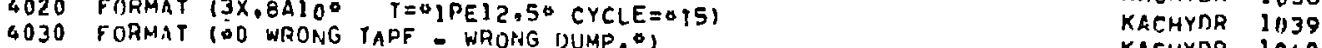

4030 FORMAT 1SO WRONG TAPF - WROHG DUMP, BJ

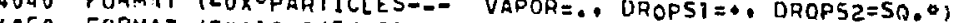

4060 KACHYDR I04

0000 FORMAT (1H,

FIMAT

I EI2.5) KACHYDR IO45

9090 FOAM $12(1 \times 13), 3 \times, 8(2 x, 1 P F 12.5) / 11 \times \cdot 8(2 x, 1 P E 12.5) 1)$ KACHYDR 1046

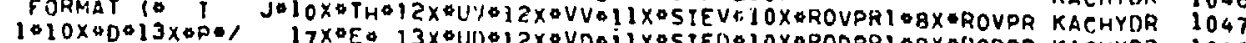

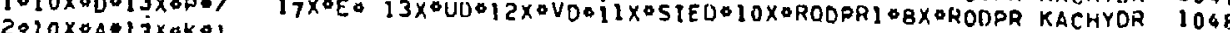
FORMAT io T:O MOMR:

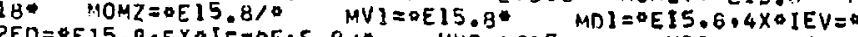

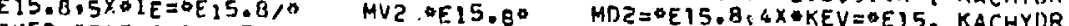

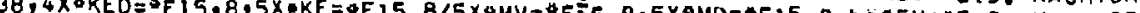
$48,5 \times \circ E 0=0 E 15,8,6 \times 0=0 E 15,01)$ END

KACHYDR 
INDEX 01/00/75

SINGLY REFEPETCET VARIAHLES

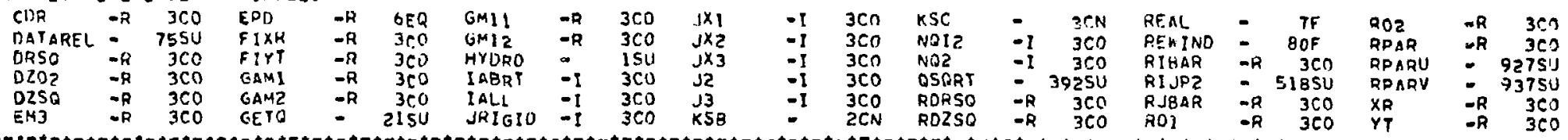

MUITIPLY-REFEREHCEU YARIABLES

$100-25 \%$ Ba 950

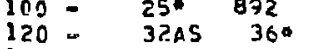

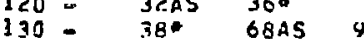

$139=4800 \quad 490$

$149=\quad 300 \quad 480$

$150=40 \quad 500$

$210=33620$

$220-36 \quad 670$

$230-37 \quad 70$

$250=69 \quad 71 \%$

$270-23 \quad 80^{\circ}$

$280=850950$

$300=34 \quad 63$

$310=100 \% 131$

$320=1031120$

$330=1160122^{\circ}$

$340=128$

$400=112001230$

$409=135001390$

$49=135001400$

$429=155001650$

$439=15200166^{\circ}$

$469=14100142$

$609=17500,1780$

$609=175001790$

$619=17400180$

$639=184001880$

$640=181130^{\circ}$

$649=193001940$

$710=219$ 224AS 2260

$720=226$ 23145 2:34

$730=233$ 2384

$740=225232 \quad 239246$

$769=21100217$ 240 24545 256:

779 - 20600258.

7A7 - $2030026 ! *$

$799=1690019 i^{\circ} 262$.

820168 263.

$820=266$ 267.

840 : 263AS 272.

850 - 278 278 279.

$\begin{array}{lll}860^{\circ} \circ & 271 & 282 * \\ 870-26845 & 279 & \end{array}$ 


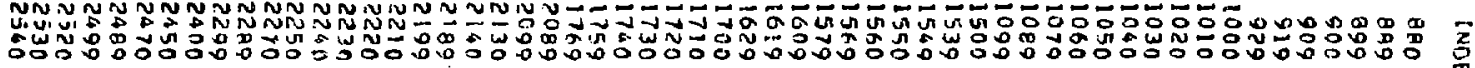
$1,1,1,1,1,1,1,1,1,1,1,1,1,1,1,1,1,1,1,1,1,1,1,1,1, x$

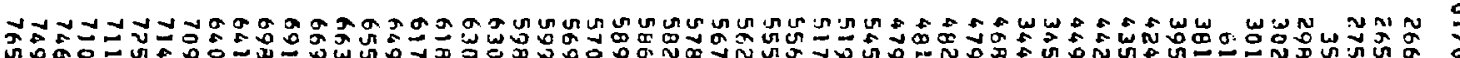

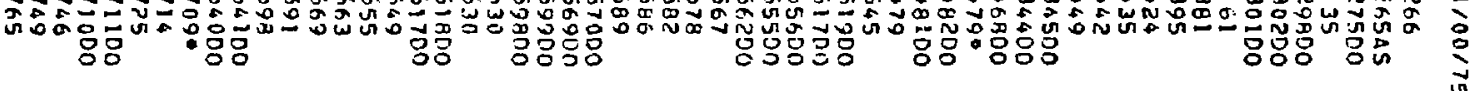

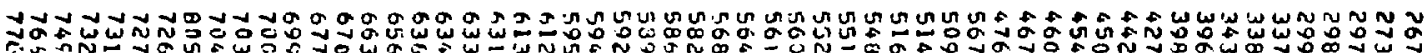

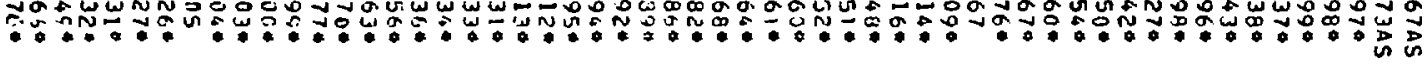


$3560-1797920$

$7585=796 \quad 791 \quad 1760$

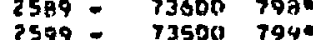

$2589=735007940$

$2610=813$ HI4.

$7 \in 20=$ Al3 Bito

$2630=$ Bis Hife

i360 - 815 HIT 0200

$2650=420$ B230

$30 \mathrm{nt}=\$ 23 \quad 4260$

$2570-120$ स240

$3690=629$ 11320

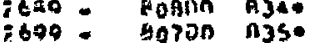

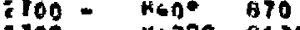

E. Mason R6.T"

709 - Bulto Ho50

3000 - by

30en - ATSOn BAs:

$2949=172000^{\circ}$

jilo:

3130 - $90 \mathrm{2}$ 905.

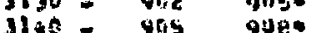

Jiten - Boson 000

1108 -

300 - 01500 ?

43 904 908

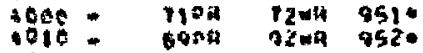

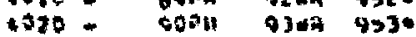

1078 - 0501056

1000 - insell 95so

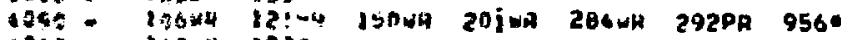

10ne - 16940 $457^{\circ}$

1032 - 300.4 950*

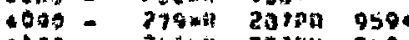

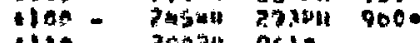

1110 - 7obju $9 t_{2} 10$

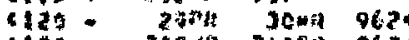

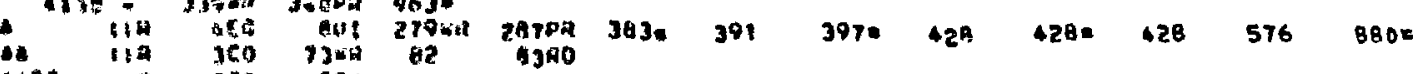

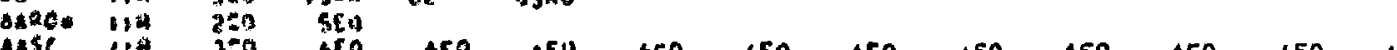

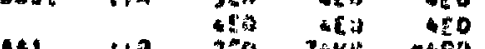

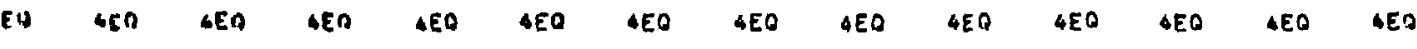

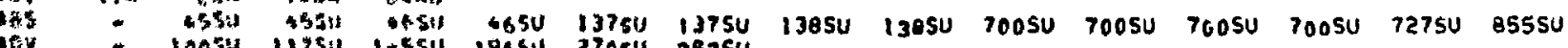

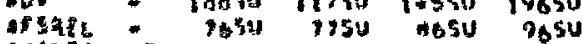

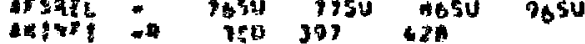

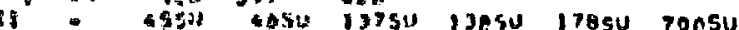

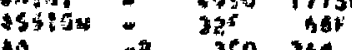

1,160

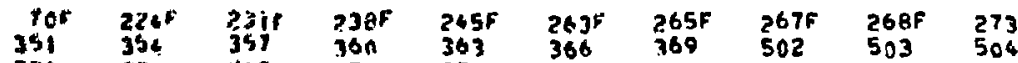

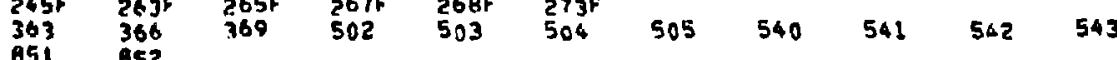




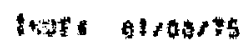

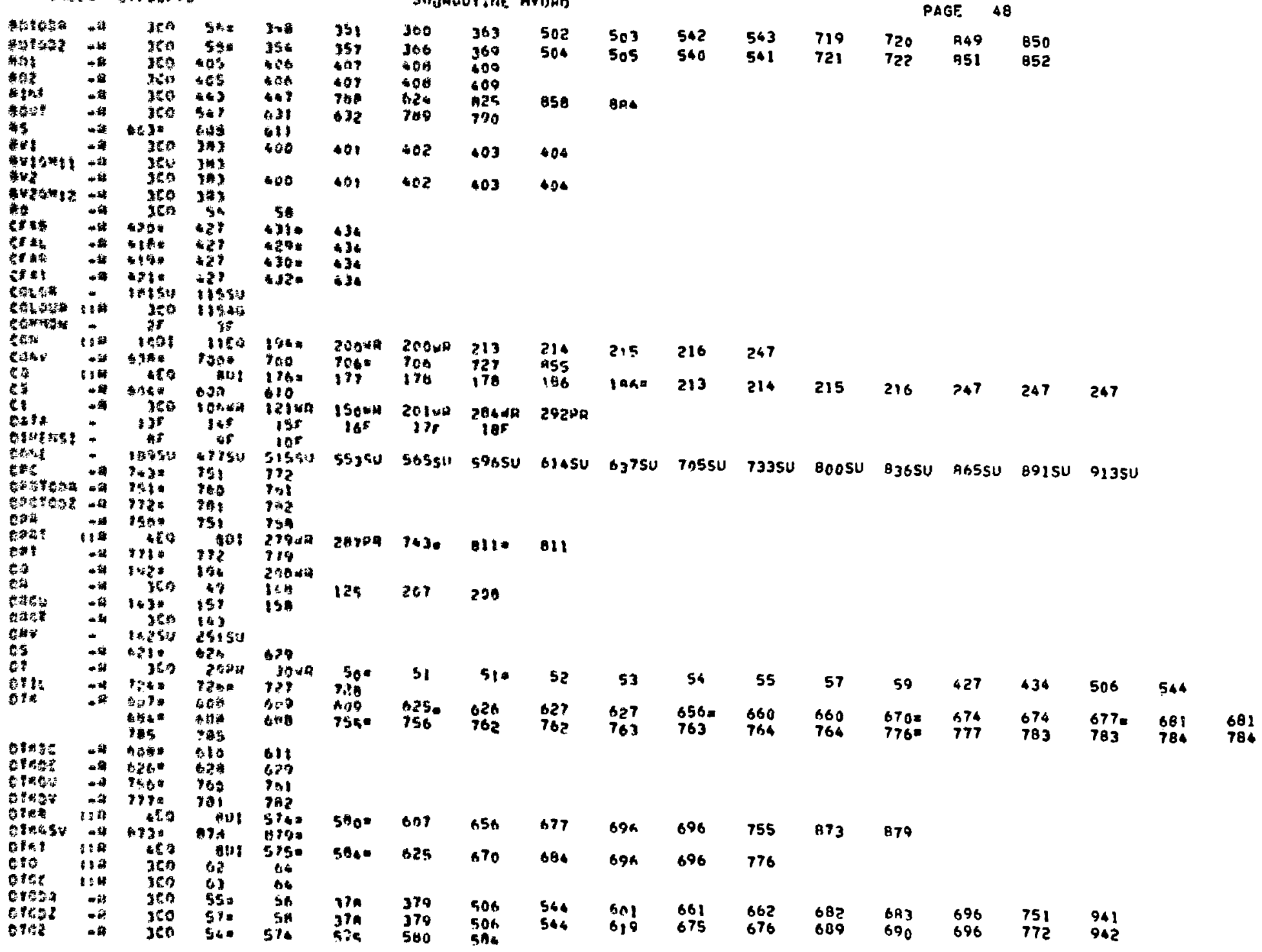




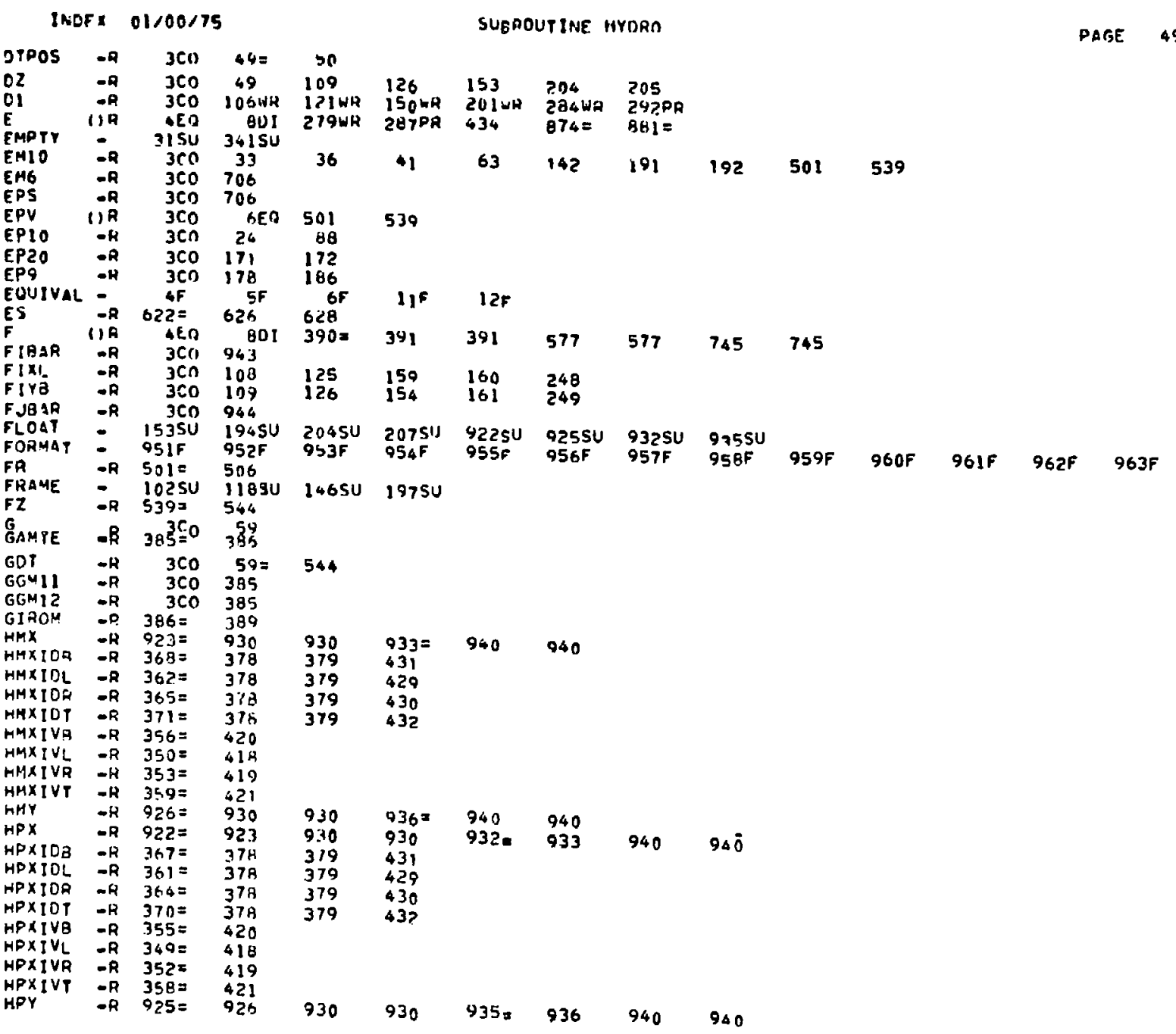




\begin{tabular}{|c|c|c|c|c|c|c|c|c|c|c|c|c|c|c|c|c|c|c|}
\hline & $-I$ & $\begin{array}{l}300 \\
3 r 7 \\
422 \\
451 \\
533 \\
668 \\
696 \\
820 \\
931=\end{array}$ & $\begin{array}{l}4400 \\
309 \\
426 \\
452 \\
544 \\
685 \\
696 \\
826 \\
932\end{array}$ & $\begin{array}{l}13600 \\
310 \\
426 \\
453 \\
544 \\
647 \\
696 \\
84200 \\
938\end{array}$ & $\begin{array}{l}155110 \\
317 \\
426 \\
454 \\
544 \\
618 \\
71100 \\
856\end{array}$ & $\begin{array}{l}156 \\
313 \\
427 \\
455 \\
55600 \\
658 \\
724 \\
854\end{array}$ & $\begin{array}{l}17500 \\
314 \\
427 \\
456 \\
56200 \\
688 \\
724 \\
854\end{array}$ & $\begin{array}{l}18500 \\
315 \\
427 \\
457 \\
57000 \\
549 \\
724 \\
557\end{array}$ & $\begin{array}{l}206000 \\
316 \\
427 \\
46900 \\
578 \\
689 \\
725 \\
859\end{array}$ & $\begin{array}{l}207 \\
34500 \\
4.33 \\
469 \\
586 \\
690 \\
726 \\
87500\end{array}$ & $\begin{array}{l}27600 \\
372 \\
433 \\
470 \\
59900 \\
690 \\
726 \\
883\end{array}$ & $\begin{array}{l}779 \text { WR } \\
373 \\
433 \\
473 \\
61800 \\
695 \\
73600 \\
885\end{array}$ & $\begin{array}{l}287 P R \\
374 \\
434 \\
474 \\
64100 \\
695 \\
746 \\
89500\end{array}$ & $\begin{array}{l}29800 \\
375 \\
434 \\
48200 \\
649 \\
695 \\
749 \\
896\end{array}$ & $\begin{array}{l}299 \\
378 \\
434 \\
506 \\
666 \\
695 \\
80800 \\
902\end{array}$ & $\begin{array}{l}302 n 0 \\
379 \\
434 \\
506 \\
665 \\
696 \\
819 \\
921=\end{array}$ & $\begin{array}{l}305 \\
422 \\
435 \\
504 \\
666 \\
696 \\
819 \\
97 ?\end{array}$ & $\begin{array}{l}306 \\
422 \\
450 \\
51900 \\
667 \\
198 \\
817 \\
928\end{array}$ \\
\hline $\begin{array}{l}\text { IBAR } \\
\text { IC } \\
\text { ICHAR } \\
\text { ICHARS } \\
\text { ICI } \\
\text { ICD } \\
\text { IOCON } \\
\text { IOFP } \\
\text { IOTO } \\
\text { IOVV } \\
\text { II } \\
\text { IJ }\end{array}$ & $\begin{array}{l}-1 \\
-1 \\
-1 \\
11 \\
-1 \\
-1 \\
-1 \\
11 \\
11 \\
-1 \\
11 \\
-1 \\
-1\end{array}$ & $\begin{array}{l}300 \\
10300 \\
114= \\
10 D 1 \\
27 c= \\
271= \\
1001 \\
1001 \\
360 \\
1001 \\
2146 \\
300\end{array}$ & $\begin{array}{l}23 \\
194 \\
127 \mathrm{AG} \\
150 A \\
227= \\
228= \\
170 A \\
140 A \\
62 \\
160 A \\
27 \\
137\end{array}$ & $\begin{array}{l}11146 \\
234= \\
235= \\
199 \mathrm{WR} \\
120 \mathrm{WR} \\
63 \\
148 \mathrm{WR}\end{array}$ & $\begin{array}{l}114 \\
241= \\
242=\end{array}$ & $\begin{array}{l}479 \\
200 \mathrm{WR}\end{array}$ & $\begin{array}{l}48200 \\
21100\end{array}$ & $\begin{array}{l}557 \\
253\end{array}$ & $? 49$ & & & & & & & & & \\
\hline & & $\begin{array}{l}300 \\
179= \\
307 \\
325 \\
376 \\
382 \\
391 \\
400 \\
476 \\
463 \\
510 \\
573 \\
587 \\
674 \\
689 \\
715 \\
763 \\
764 \\
810 \\
844 \\
882 \\
428\end{array}$ & $\begin{array}{l}137 \\
179 \\
304 \\
325 \\
377 \\
383 \\
391 \\
425 \\
428 \\
464 \\
510 \\
574 \\
590 \\
633= \\
284 \\
717 \\
744 \\
793 \\
818 \\
345 \\
432 \\
979\end{array}$ & $\begin{array}{l}137 \\
186 \\
310 \\
326 \\
378 \\
3 \times 3 \\
391 \\
405 \\
428 \\
464 \\
517= \\
574 \\
592= \\
633 \\
635 \\
723 \\
745 \\
749 \\
819 \\
847 \\
1183 \\
930\end{array}$ & $\begin{array}{l}138 \\
196 \\
310 \\
326 \\
378 \\
383 \\
391 \\
405 \\
428 \\
455 \\
512 \\
575 \\
690 \\
647 \\
685 \\
724 \\
745 \\
799 \\
710 \\
247 \\
844 \\
029\end{array}$ & $\begin{array}{l}13 H \\
187= \\
312 \\
3378 \\
378 \\
383 \\
343 \\
405 \\
432 \\
460 \\
529 \\
575 \\
601 \\
643 \\
697 \\
726 \\
745 \\
754 \\
819 \\
854 \\
884 \\
070\end{array}$ & $\begin{array}{l}139= \\
187 \\
313 \\
346 \\
378 \\
334 \\
397 \\
421 \\
433 \\
469 \\
544 \\
576 \\
607 \\
644 \\
691 \\
726 \\
745 \\
795 \\
821 \\
856 \\
A 65\end{array}$ & $\begin{array}{l}139 \\
209 \\
313 \\
347 \\
378 \\
384 \\
372 \\
422 \\
433 \\
470 \\
547 \\
676 \\
603 \\
645 \\
695 \\
728 \\
745 \\
796= \\
822 \\
656 \\
886\end{array}$ & $\begin{array}{l}157 \\
217 \\
3,4 \\
351 \\
378 \\
385 \\
392 \\
422 \\
434 \\
471 \\
548 \\
577 \\
604 \\
647 \\
696 \\
72 A \\
753 \\
809 \\
824 \\
851= \\
987=\end{array}$ & $\begin{array}{l}157 \\
227 \\
314 \\
351 \\
378 \\
385 \\
394 \\
425 \\
434 \\
472 \\
549= \\
577 \\
605 \\
657 \\
696 \\
728 \\
754 \\
819 \\
924 \\
873 \\
900\end{array}$ & $\begin{array}{l}158 \\
229 \\
314 \\
357 \\
379 \\
386 \\
394 \\
425 \\
438 \\
473 \\
549 \\
577 \\
606 \\
658 \\
697 \\
729= \\
755 \\
811 \\
825 \\
874 \\
90:\end{array}$ & $\begin{array}{l}165= \\
257= \\
314 \\
357 \\
379 \\
386 \\
397 \\
425 \\
439 \\
476 \\
557 \\
577 \\
697 \\
659 \\
699 \\
737 \\
763 \\
811 \\
825 \\
976 \\
99,6\end{array}$ & $\begin{array}{l}165 \\
260= \\
315 \\
363 \\
379 \\
388 \\
397 \\
425 \\
445 \\
475= \\
557 \\
577 \\
610 \\
671 \\
697 \\
739 \\
754 \\
811 \\
877 \\
877 \\
967\end{array}$ & $\begin{array}{l}176 \\
260 \\
315 \\
363 \\
379 \\
389 \\
398 \\
425 \\
446 \\
475 \\
559= \\
577 \\
611 \\
672 \\
700 \\
739 \\
768 \\
812 \\
828 \\
978 \\
909=\end{array}$ & $\begin{array}{l}176 \\
313 \\
316 \\
369 \\
379 \\
389 \\
399 \\
426 \\
458= \\
483 \\
559 \\
579 \\
612= \\
673 \\
701= \\
740 \\
769 \\
812 \\
830 \\
879 \\
909\end{array}$ & $\begin{array}{l}177 \\
304 \\
316 \\
369 \\
379 \\
390 \\
400 \\
428 \\
461 \\
506 \\
571 \\
580 \\
619 \\
677 \\
712 \\
741 \\
774 \\
814 \\
931 \\
880 \\
912=\end{array}$ & $\begin{array}{l}175 \\
305 \\
320 \\
372 \\
380 \\
391 \\
410 \\
496 \\
467 \\
507= \\
572 \\
583 \\
620 \\
678 \\
717 \\
787 \\
775 \\
815 \\
8972 \\
880 \\
912\end{array}$ & $\begin{array}{l}178 \\
306 \\
321 \\
374 \\
382 \\
391 \\
400 \\
426 \\
463 \\
507 \\
573 \\
584 \\
623 \\
679 \\
714 \\
742 \\
776 \\
816 \\
843 \\
881 \\
928=\end{array}$ \\
\hline $\begin{array}{l}1 \mathrm{JA} \\
1 \mathrm{JM}\end{array}$ & $\begin{array}{l}-1 \\
-I\end{array}$ & $\begin{array}{l}48.3= \\
360\end{array}$ & $\begin{array}{r}929 \\
486 \\
45\end{array}$ & $\begin{array}{r}930 \\
487 \\
45\end{array}$ & $\begin{array}{l}93 n \\
490\end{array}$ & $\begin{array}{l}938= \\
473=\end{array}$ & $\begin{array}{l}33.8 \\
494\end{array}$ & $\begin{array}{l}9.30 \\
496\end{array}$ & $\begin{array}{l}940 \\
520=\end{array}$ & $\begin{array}{l}940 \\
523\end{array}$ & 524 & 527 & 530 & 531 & 5.35 & 546 & & $928=$ \\
\hline & & $\begin{array}{l}335= \\
493 \\
463 \\
474\end{array}$ & $\begin{array}{l}335 \\
403 \\
444 \\
476=\end{array}$ & $\begin{array}{l}45 \\
354 \\
408 \\
405 \\
416\end{array}$ & $\begin{array}{r}46 \\
354 \\
409 \\
446 \\
425\end{array}$ & $\begin{array}{l}46 \\
366 \\
4118 \\
447 \\
504=\end{array}$ & $\begin{array}{c}477 \\
366 \\
498 \\
449 \\
519\end{array}$ & $\begin{array}{l}47 \\
378 \\
414 \\
450 \\
514=\end{array}$ & $\begin{array}{l}158 \\
378 \\
490 \\
451 \\
514\end{array}$ & $\begin{array}{l}1642 \\
379 \\
420 \\
45 ? \\
537\end{array}$ & $\begin{array}{l}164 \\
379 \\
472 \\
453\end{array}$ & $\begin{array}{l}277 \\
384 \\
425 \\
460=\end{array}$ & $\begin{array}{l}295= \\
392 \\
475 \\
460\end{array}$ & $\begin{array}{l}795 \\
392 \\
426 \\
469\end{array}$ & $\begin{array}{l}297= \\
403 \\
426 \\
470\end{array}$ & $\begin{array}{l}297 \\
403 \\
431 \\
471\end{array}$ & $\begin{array}{l}325 \\
403 \\
431 \\
472\end{array}$ & $\begin{array}{l}326 \\
403 \\
433 \\
473\end{array}$ \\
\hline Aטין & -1 & $\begin{array}{l}563 \\
621 \\
724 \\
84 B \\
904 \\
485=\end{array}$ & $\begin{array}{l}40= \\
504= \\
629 \\
726 \\
650 \\
976 \\
609\end{array}$ & $\begin{array}{l}410 \\
564 \\
631 \\
730= \\
658 \\
907 \\
447\end{array}$ & $\begin{array}{l}455 \\
543 \\
631 \\
790 \\
103= \\
909= \\
500\end{array}$ & $\begin{array}{l}5{ }^{4}= \\
544= \\
632 \\
787 \\
862 \\
91.4 \\
500\end{array}$ & $\begin{array}{l}569 \\
584 \\
637 \\
989 \\
994 \\
911= \\
527=\end{array}$ & $\begin{array}{l}514= \\
585 \\
634= \\
784 \\
864= \\
911 \\
528\end{array}$ & $\begin{array}{l}514 \\
585 \\
634 \\
790 \\
889 \\
990=\end{array}$ & $\begin{array}{l}522 \\
594= \\
645 \\
794 \\
897 \\
940 \\
530\end{array}$ & $\begin{array}{l}547 \\
594 \\
670 \\
795 \\
897 \\
940\end{array}$ & $\begin{array}{l}551= \\
619 \\
671 \\
797= \\
898\end{array}$ & $\begin{array}{l}551 \\
620 \\
672 \\
797 \\
898\end{array}$ & $\begin{array}{l}558 \\
621 \\
673 \\
919 \\
900\end{array}$ & $\begin{array}{l}558 \\
622 \\
696 \\
824 \\
901\end{array}$ & $\begin{array}{l}560= \\
62.3 \\
703= \\
825 \\
90.3\end{array}$ & $\begin{array}{l}560 \\
620 \\
703 \\
874= \\
013\end{array}$ & $\begin{array}{l}563 \\
625 \\
718 \\
834 \\
904\end{array}$ \\
\hline
\end{tabular}




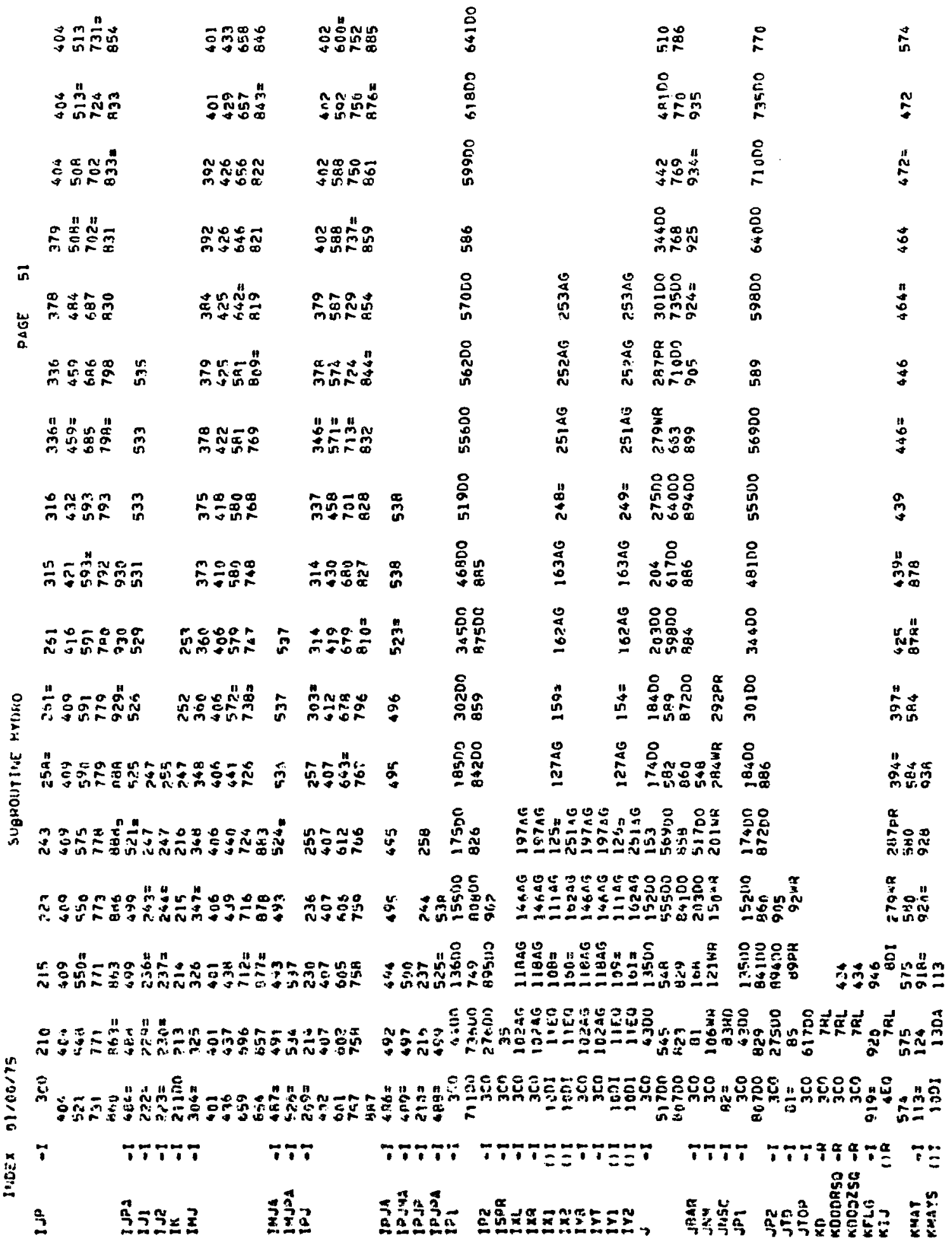




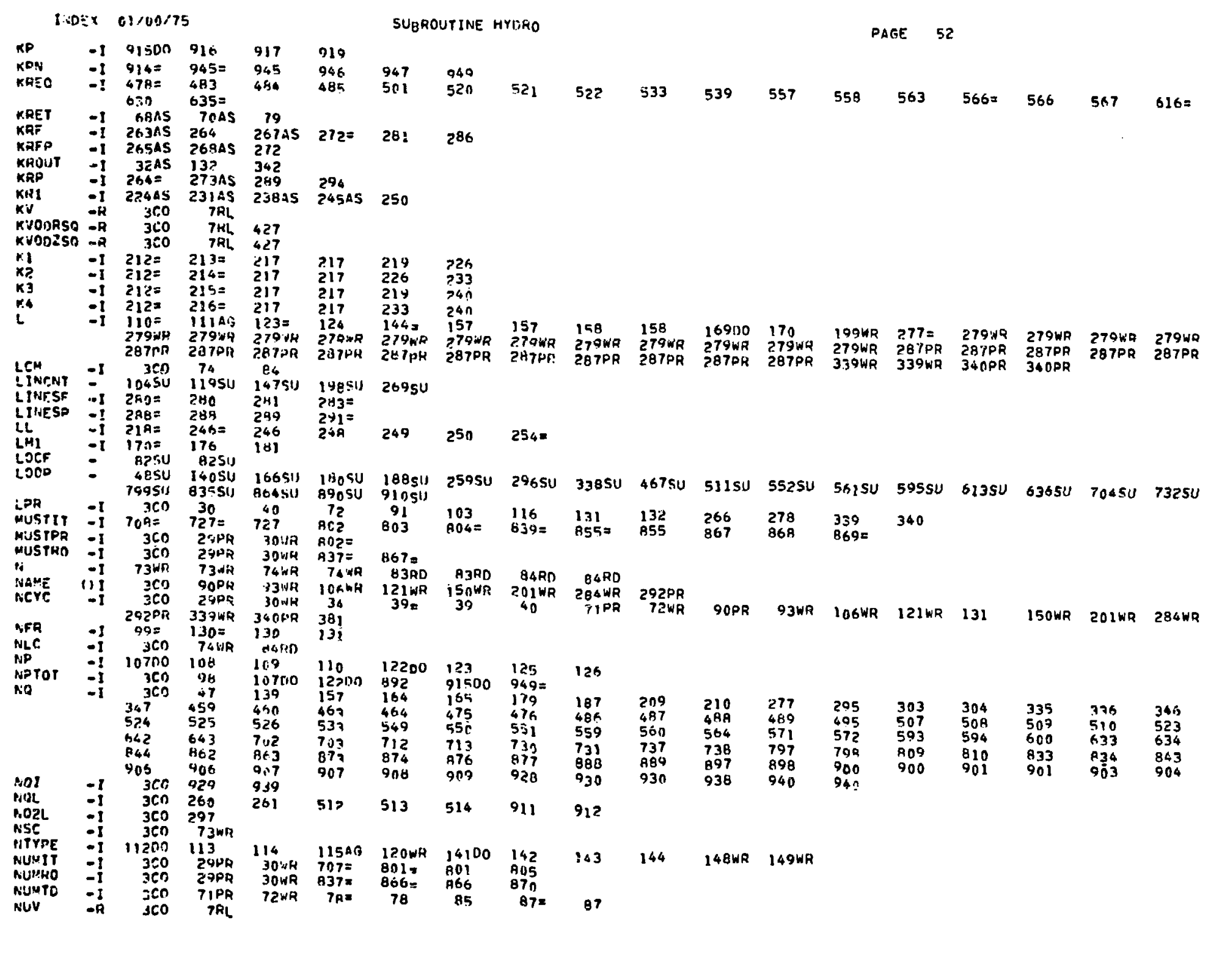




\begin{tabular}{|c|c|c|c|c|c|c|c|c|c|c|c|c|c|c|c|c|c|c|}
\hline IND & DEX & $01 / 00 / 1$ & & & & SUGRO & 17 INF. & YYORO & & & & & & GE & & & & \\
\hline Nuv 3 & -4 & 300 & TRL & 394 & & & & & & & & & & & & & & \\
\hline $\begin{array}{l}\text { NVAD } \\
\text { OMUASS }\end{array}$ & $\begin{array}{l}-1 \\
-8\end{array}$ & $\begin{array}{l}3 \mathrm{Cn} \\
3 \mathrm{CO}\end{array}$ & $\begin{array}{r}813 \\
60\end{array}$ & 838 & & & & & & & & & & & & & & \\
\hline $\begin{array}{l}\text { CMEETA } \\
\text { OMESPP }\end{array}$ & 118 & $\begin{array}{ll}4 E Q \\
3 C Q\end{array}$ & $\begin{array}{l}801 \\
60=1\end{array}$ & $\begin{array}{l}697= \\
699\end{array}$ & $679=$ & 728 & 811 & $819=$ & 856 & & & & & & & & & \\
\hline $\begin{array}{l}\text { он } \\
\text { о }\end{array}$ & $\begin{array}{l}-A \\
-R\end{array}$ & 360 & $\begin{array}{l}00= \\
697\end{array}$ & & & & & & & & & & & & & & & \\
\hline OMTNAB & $\begin{array}{l}-R \\
-R\end{array}$ & $\begin{array}{r}360 \\
-15=0\end{array}$ & $\begin{array}{l}819 \\
426\end{array}$ & 434 & & & & & & & & & & & & & & \\
\hline OMTHL & -4 & $411=$ & 426 & 434 & & & & & & & & & & & & & & \\
\hline OMTAPG & $-R$ & $413=$ & 426 & 434 & & & & & & & & & & & & & & \\
\hline PIATHTB & UR & $\begin{array}{l}417= \\
4 E_{1}\end{array}$ & ${ }^{426}{ }_{H O I}$ & $\begin{array}{l}434 \\
279 N R\end{array}$ & $237{ }^{2} 4$ & & & & & & & & & & & & & \\
\hline & $-H$ & $\begin{array}{l}601 \\
692=\end{array}$ & $\begin{array}{l}601 \\
696\end{array}$ & & 619 & 728 & $\begin{array}{l}391= \\
741\end{array}$ & $\begin{array}{l}393 \\
742=\end{array}$ & $\begin{array}{l}426 \\
747=\end{array}$ & 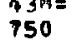 & $\begin{array}{l}438 \\
766=\end{array}$ & $\begin{array}{l}445= \\
771\end{array}$ & $\begin{array}{l}945 \\
787=\end{array}$ & $\begin{array}{l}463= \\
792=\end{array}$ & 463 & $471=$ & 471 & 577 \\
\hline ARUR & $-R$ & $\begin{array}{l}694= \\
694=\end{array}$ & 595 & & & & & & & & & & & & & & & \\
\hline $\begin{array}{l}\text { PAAVB } \\
\text { DARVT }\end{array}$ & $\begin{array}{l}-A \\
-R\end{array}$ & $\begin{array}{l}693= \\
695=\end{array}$ & $\begin{array}{l}696 \\
696\end{array}$ & & & & & & & & & & & & & & & \\
\hline PE & $-R$ & $741=$ & 743 & & & & & & & & & & & & & & & \\
\hline PL & UR & $\begin{array}{ll}11515 \\
G E O\end{array}$ & 127 SU & $\begin{array}{l}163511 \\
728=\end{array}$ & 25250 & 253511 & & & & & & & & & & & & \\
\hline ppc & $-R$ & $\begin{array}{l}442=0 \\
742=\end{array}$ & $\begin{array}{l}801 \\
743\end{array}$ & $\begin{array}{l}728= \\
745\end{array}$ & $\begin{array}{l}742 \\
747\end{array}$ & $\begin{array}{l}750 \\
766\end{array}$ & $\begin{array}{l}771 \\
>87\end{array}$ & & & & & & & & & & & \\
\hline $\begin{array}{l}\text { PRINT } \\
\text { PTE }\end{array}$ & $-R$ & $\begin{array}{r}29 F \\
4232\end{array}$ & $\begin{array}{r}71 F \\
426=\end{array}$ & $89 r$ & & & $287 \mathrm{~F}$ & $290 \mathrm{~F}$ & $292 F$ & $293 \mathrm{~F}$ & $340 F$ & & & & & & & \\
\hline $\begin{array}{l}\text { PUDENLL } \\
\text { PLOENRE }\end{array}$ & $\begin{array}{l}-A \\
-A\end{array}$ & $\begin{array}{l}652= \\
652\end{array}$ & $\begin{array}{l}660= \\
601=\end{array}$ & 642 & & & & & & & & & & & & & & \\
\hline PVOENB & $-\hat{-p}$ & G66 = & $\begin{array}{l}681= \\
676=\end{array}$ & $\begin{array}{l}594 \\
693\end{array}$ & & & & & & & & & & & & & & \\
\hline $\begin{array}{l}\text { PVOENT } \\
\text { P }\end{array}$ & $\begin{array}{l}118 \\
-R\end{array}$ & $\begin{array}{l}100 \mathrm{I} \\
854=\end{array}$ & $\begin{array}{l}11 \text { IIEO } \\
855\end{array}$ & $\begin{array}{l}666 \\
856\end{array}$ & $6 B_{B}=$ & 695 & & & & & & & & & & & & \\
\hline N & $-R$ & $171=$ & $171=$ & 177 & 1н2 & 190 & 194 & $200 \mathrm{WR}$ & & & & & & & & & & \\
\hline a & $\begin{array}{l}-A \\
-A\end{array}$ & $\begin{array}{r}172= \\
360\end{array}$ & $\begin{array}{l}179= \\
427\end{array}$ & $\begin{array}{l}178 \\
434\end{array}$ & 182 & 182 & $186=$ & 190 & ZoowR & & & & & & & & & \\
\hline $\begin{array}{l}\text { RA } \\
\text { REETA }\end{array}$ & 11R & $\begin{array}{r}4 E 0 \\
606=\end{array}$ & 801 & $576=$ & 577 & 644 & 696 & 745 & 753 & 779 & A80 & & & & & & & \\
\hline RCONT & UR & 360 & 510 & $7 \in$. & 769 & & & & & & & & & & & & & \\
\hline ROR & $\begin{array}{l}-R \\
-A\end{array}$ & $609=$ & 610 & 611 & $627=$ & $62 B$ & 629 & $702=$ & 763 & 764 & $783=$ & 784 & 785 & & & & & \\
\hline Tט & $-A$ & 300 & $53=$ & 69 & 696 & 724 & 819 & 854 & & & & & & & & & & \\
\hline READ & $\because$ & $\begin{array}{l}360 \\
835\end{array}$ & $\begin{array}{l}57 \\
845\end{array}$ & 422 & 426 & 427 & 433 & 434 & 636 & 724 & 726 & H54 & & & & & & \\
\hline & & 385 & 9750 & & & & & & & & & & & & & & & \\
\hline RI RI & $\begin{array}{l}11 R \\
-R\end{array}$ & $\begin{array}{l}360 \\
360\end{array}$ & $\begin{array}{r}156 \\
28\end{array}$ & 506 & $5 n 6$ & & & & & & & & & & & & & \\
\hline & (1A & $696^{360}$ & $\begin{array}{l}372 \\
690\end{array}$ & $\begin{array}{l}373 \\
696\end{array}$ & $\begin{array}{l}374 \\
696\end{array}$ & $\begin{array}{l}375 \\
724\end{array}$ & 422 & $\begin{array}{l}422 \\
736\end{array}$ & 426 & 426 & 427 & 427 & 433 & 433 & 436 & 434 & 548 & 544 \\
\hline $\begin{array}{l}\text { RHSO } \\
\text { ROOS } \\
\text { Rog }\end{array}$ & $\begin{array}{l}-R \\
-R\end{array}$ & $\begin{array}{l}384= \\
665=\end{array}$ & $\begin{array}{l}390 \\
673=\end{array}$ & & & & & & 726 & 819 & 819 & 854 & 854 & & & & & \\
\hline $\begin{array}{l}\text { AOOL } \\
\text { RONPA }\end{array}$ & 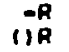 & $\begin{array}{l}651= \\
4 E 0\end{array}$ & $\begin{aligned} 559= \\
801\end{aligned}$ & $\begin{array}{l}660 \\
279 \mathrm{WR}\end{array}$ & 660 & $\begin{array}{l}692 \\
306\end{array}$ & & & & & & & & & & & & \\
\hline & & $\begin{array}{l}378 \\
583=\end{array}$ & $\begin{array}{l}378 \\
583\end{array}$ & $\begin{array}{l}389 \\
567=\end{array}$ & $\begin{array}{l}605 \\
567\end{array}$ & $\begin{array}{l}405 \\
540 .\end{array}$ & $\begin{array}{l}406 \\
590\end{array}$ & $\begin{array}{l}314 \\
40 n \\
606\end{array}$ & $\begin{array}{l}134 \\
407 \\
6\end{array}$ & $\begin{array}{l}310 \\
407\end{array}$ & $\begin{array}{l}316 \\
408\end{array}$ & $\begin{array}{l}379 \\
409\end{array}$ & $\begin{array}{l}379 \\
409\end{array}$ & $\begin{array}{l}778 \\
409\end{array}$ & $\begin{array}{l}378 \\
434\end{array}$ & $\begin{array}{l}379 \\
573=\end{array}$ & $\begin{array}{l}378 \\
579=\end{array}$ & $\begin{array}{l}378 \\
579\end{array}$ \\
\hline & & & & & & 180 & & & & & $6 ? .4$ & 659 & 659 & 673 & 673 & & $6 B O$ & \\
\hline $\begin{array}{l}\text { DPAF } \\
\text { OPA, }\end{array}$ & 11P & GED & HDI & $37 A=$ & & & & & & & & & & & & & & \\
\hline 3000 & & 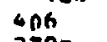 & 406 & 407 & $\begin{array}{l}28708 \\
407\end{array}$ & $\begin{array}{l}312 \\
408\end{array}$ & $\begin{array}{l}313 \\
400\end{array}$ & $\begin{array}{l}379 \\
409\end{array}$ & 379 & 374 & 379 & 379 & 379 & 370 & 379 & 379 & 405 & 05 \\
\hline & $1-6$ & & 340 & 380 & 637 & & 45 & 462 & & & & $451=$ & $462=$ & $470=$ & $47 n=$ & & & \\
\hline
\end{tabular}




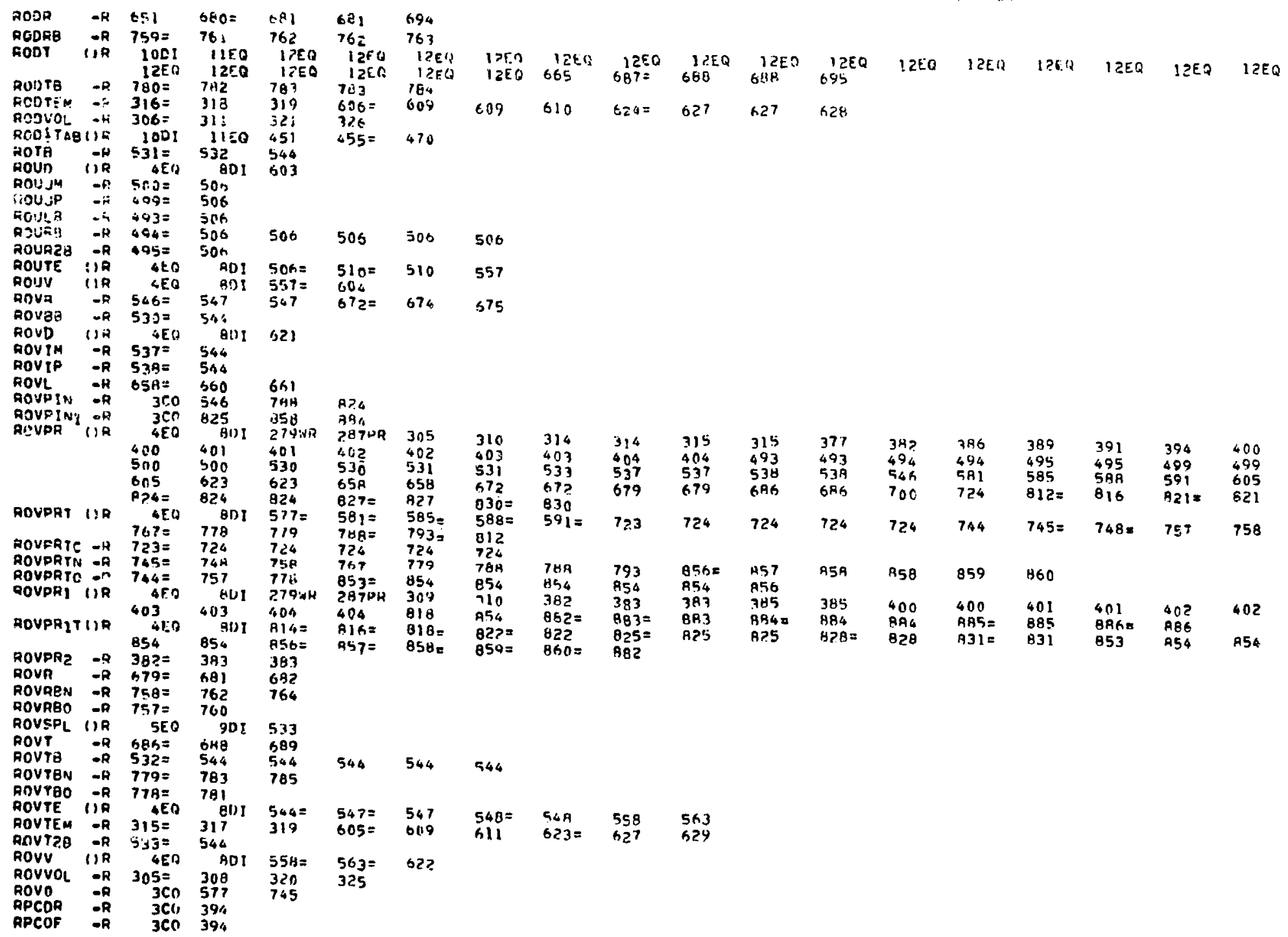




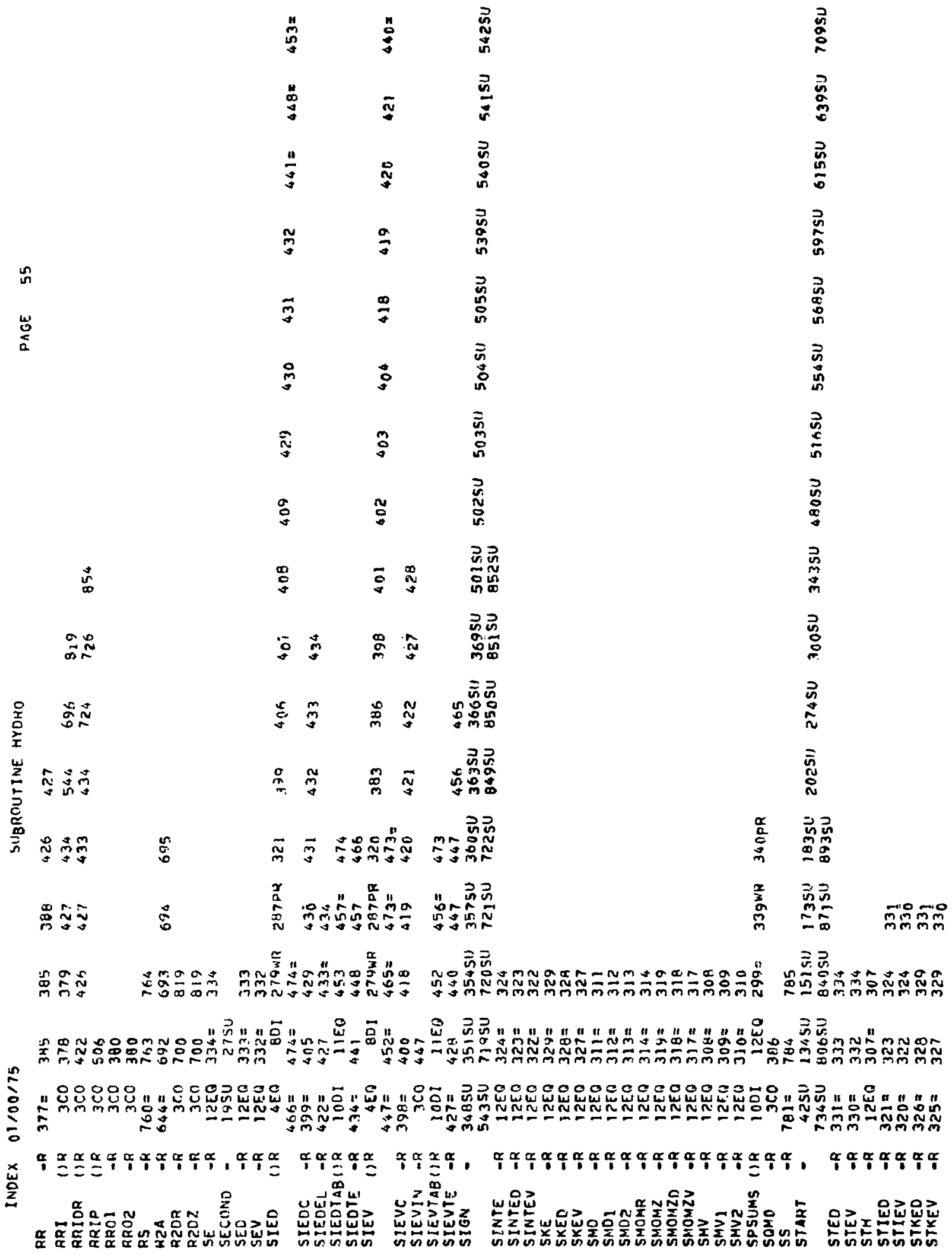




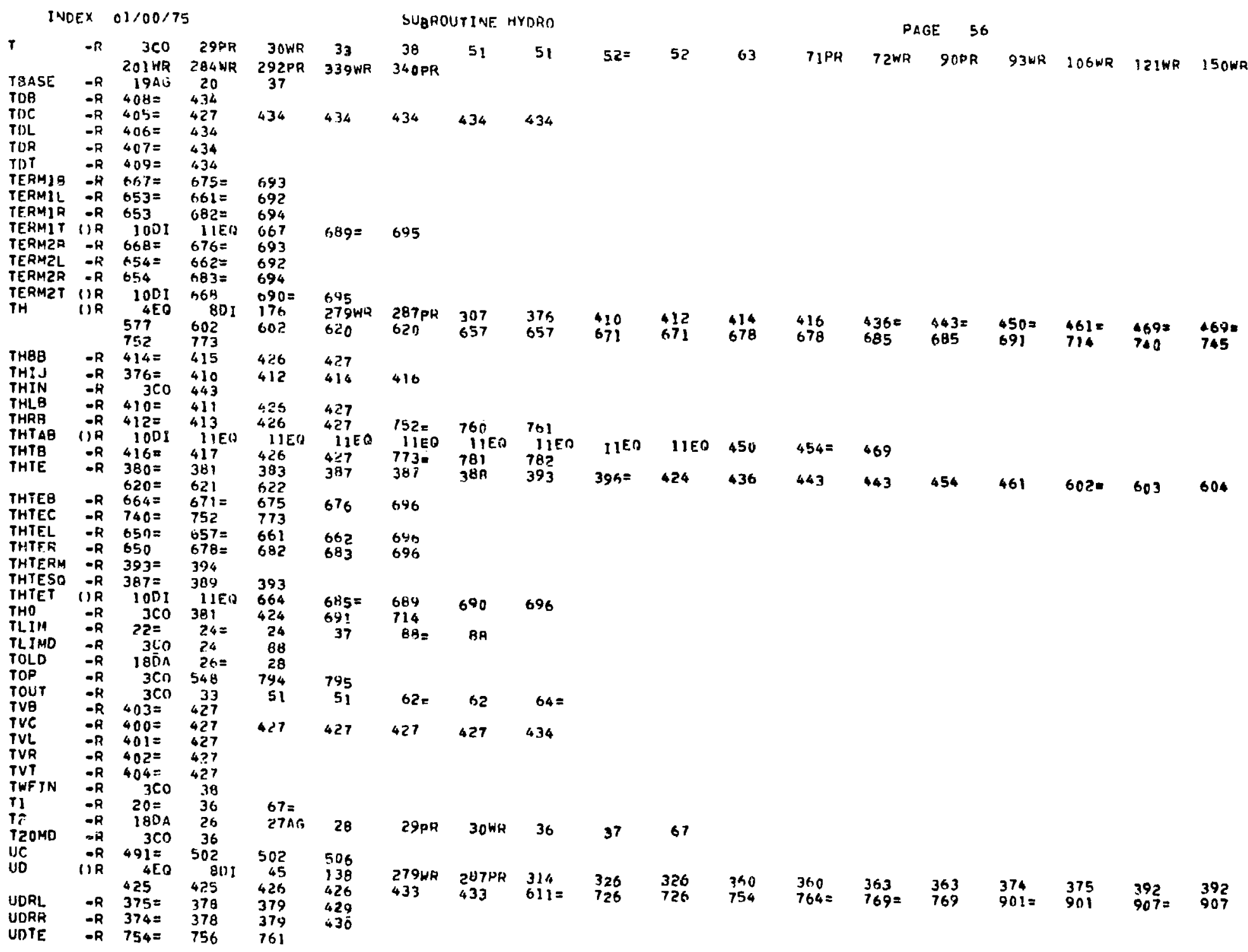




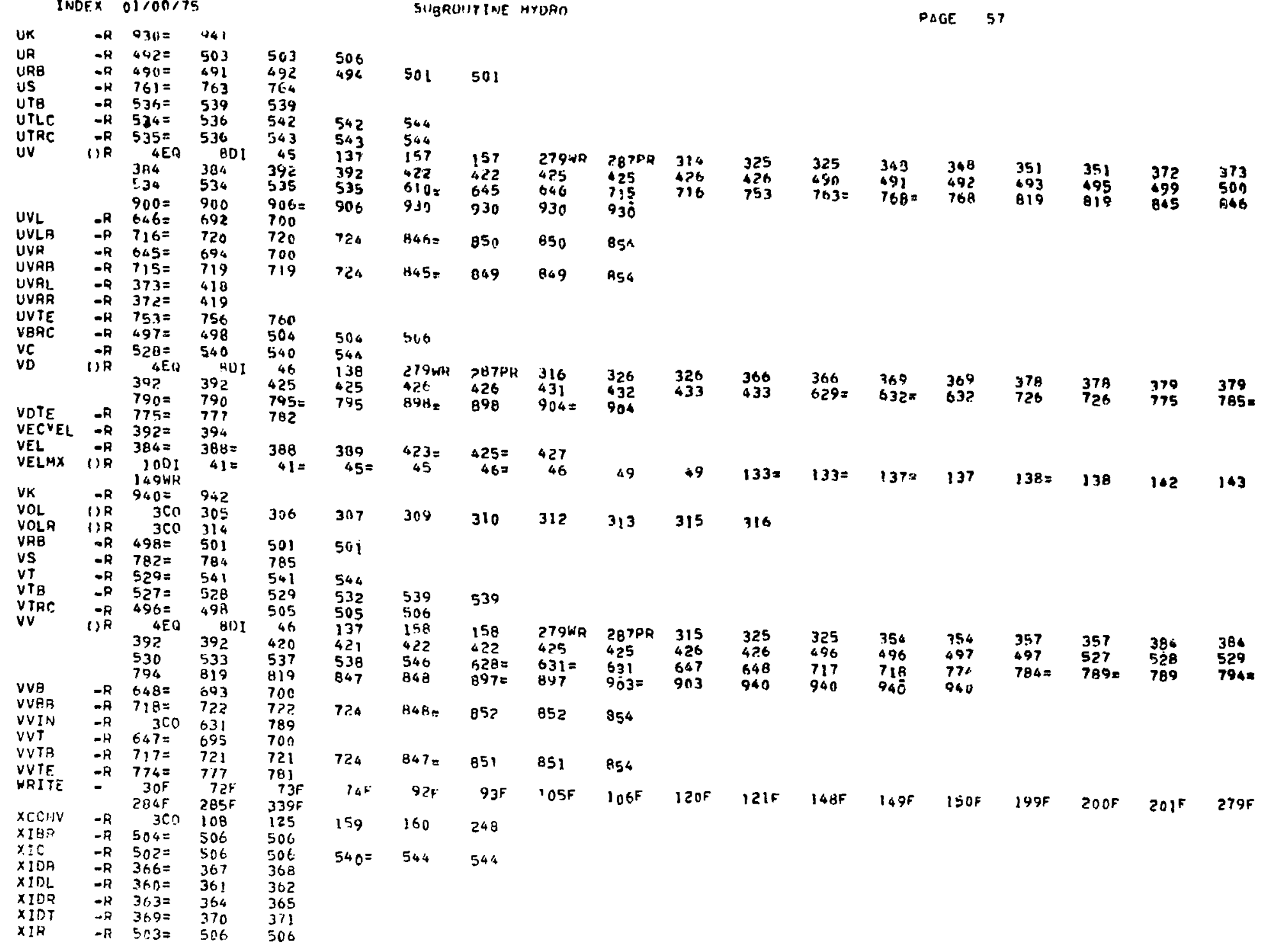


INDEX $01 / 00 / 75$

\begin{tabular}{|c|c|c|c|c|c|c|c|c|c|c|c|c|c|c|c|c|c|c|}
\hline XIT & -4 & $541=$ & 544 & 544 & & & & & & & & & & & & & & \\
\hline $\begin{array}{l}X I T L \\
X I T R\end{array}$ & $\begin{array}{l}-R \\
-R\end{array}$ & $\begin{array}{l}542= \\
505=\end{array}$ & $\begin{array}{l}544 \\
506\end{array}$ & $\begin{array}{l}544 \\
506\end{array}$ & & & & & & & & & & & & & & \\
\hline XIVB & $-R$ & $354=$ & $\begin{array}{l}700 \\
355\end{array}$ & $\begin{array}{l}300 \\
356\end{array}$ & $\begin{array}{l}543= \\
122=\end{array}$ & $\begin{array}{l}344 \\
72 \%\end{array}$ & $\begin{array}{l}544 \\
724\end{array}$ & $857=$ & & & & & & & & & & \\
\hline$x I V L$ & $-F$ & $348=$ & 349 & 350 & $720=$ & $7 ? 4$ & 724 & $850=$ & $\begin{array}{l}854 \\
854\end{array}$ & $\begin{array}{l}854 \\
854\end{array}$ & & & & & & & & \\
\hline $\begin{array}{l}X I V R \\
X I V T\end{array}$ & $-H$ & $\begin{array}{l}351= \\
357=\end{array}$ & 352 & 353 & $719=$ & 724 & 724 & $849 x$ & 854 & 854 & & & & & & & & \\
\hline $\begin{array}{l}x I V Y \\
X L\end{array}$ & $\begin{array}{l}-R \\
-R\end{array}$ & $\begin{array}{r}357= \\
3 \mathrm{C} 0\end{array}$ & $\begin{array}{l}358 \\
108\end{array}$ & $\begin{array}{l}359 \\
125\end{array}$ & $\begin{array}{l}721= \\
159\end{array}$ & $\begin{array}{l}724 \\
160\end{array}$ & $\begin{array}{l}724 \\
748\end{array}$ & $851=$ & $B \subseteq 4$ & 854 & & & & & & & & \\
\hline$X P$ & (1)R & $3 \mathrm{co}$ & 108 & 110 & 123 & 125 & 926 & 917 & $9_{A G}=$ & & & & & & & & & \\
\hline$X T E$ & $-R$ & $916=$ & 921 & 9?? & 931 & 932 & $941=$ & $94]$ & 943 & 943 & 946 & & & & & & & \\
\hline $\begin{array}{l}x x \\
x 1\end{array}$ & i) & $\begin{array}{l}28= \\
1001\end{array}$ & $\begin{array}{l}29 P P \\
1 \text { IEO }\end{array}$ & $\begin{array}{c}30 \mathrm{~W} 4 \\
156=\end{array}$ & $\begin{array}{l}192= \\
157\end{array}$ & $\begin{array}{l}196 \\
159\end{array}$ & $\begin{array}{l}190= \\
207=\end{array}$ & $\begin{array}{l}191 \\
207=\end{array}$ & 192 & $\begin{array}{l}247= \\
208=\end{array}$ & 248 & 249 & $60 \mathrm{l}=$ & 60.3 & 604 & $619=$ & 621 & 622 \\
\hline$\times 2$ & $-R$ & $157=$ & $160^{\circ}$ & & & & & & & & & 248 & 248 & 248 & & & & \\
\hline $\begin{array}{l}\text { YB } \\
\text { YCOHV }\end{array}$ & $\begin{array}{l}-R \\
-R\end{array}$ & $\begin{array}{l}3 \mathrm{Cn} \\
3 \mathrm{CO}\end{array}$ & $\begin{array}{l}109 \\
104\end{array}$ & $\begin{array}{l}1 \geq 6 \\
126\end{array}$ & $\begin{array}{l}154 \\
154\end{array}$ & $\begin{array}{l}161 \\
161\end{array}$ & 249 & & & & & & & & & & & \\
\hline YP & $1 / R$ & $3 \mathrm{CO}$ & 109 & 126 & 917 & $947=$ & 247 & & & & & & & & & & & \\
\hline YTE & $-R$ & $917=$ & 924 & 925 & 934 & $935^{\circ}$ & $942=$ & 942 & 944 & 944 & 947 & & & & & & & \\
\hline$Y_{1}$ & 118. & 1001 & $11 E Q$ & $153=$ & 154 & 158 & $204=$ & $204=$ & $205=$ & $205=$ & 205 & 249 & 249 & 249 & & & & \\
\hline $\begin{array}{l}\sqrt{2} \\
22\end{array}$ & $\begin{array}{l}-8 \\
-8\end{array}$ & $\begin{array}{r}158= \\
360\end{array}$ & $\begin{array}{r}161 \\
82\end{array}$ & & & & & & & & & & & & & & & \\
\hline
\end{tabular}


LIST OF ALL VARIABI.ES DEFINEO IN INIUT

C MEANS VARIABLE KAS DEFINED IN COMMON IN THAT HOUTINE

D MEANS VARIAELE WAS DEFIHEU IN OTHER OECLARATIONS

NON-BLANK NIMERIC IS NIMBER OF NIIN-DECLARATOHY PEFEREOLES

S PRECEDING MEANS SUBROUTINE (PROGRAM. FUNCT ION) NAMERE NLES

L PRECEDIHG MEANS CUMMUN(LCM) NAME

F PRECEUING MEANS FORTRAN KEYWORO

- pReceding means variable is declared, not used anywhere

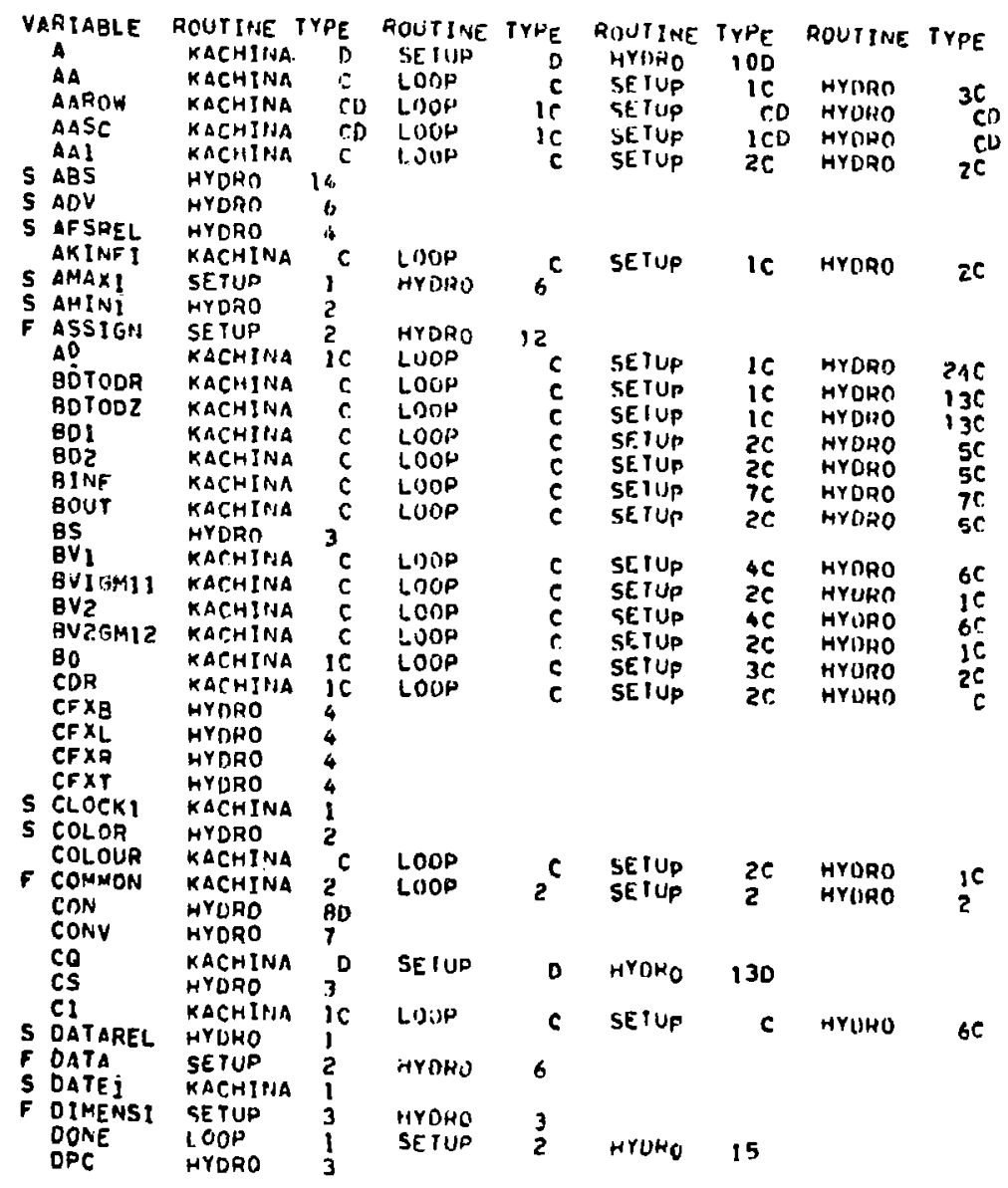




\begin{tabular}{|c|c|c|c|c|c|c|c|c|c|}
\hline & I NDEX & $01 / 00 / 75$ & & & & MAST & R IHDE & & \\
\hline & DPDTODR & HYDRO & 3 & & & & & & \\
\hline & DHDTONZ & HYORO & 3 & & & & & & \\
\hline & DPR & AYDNo & 3 & & & & & & \\
\hline & DPRT & KACHIHJA & 0 & SETH: & D & HYDRO & 5D & & \\
\hline & $\begin{array}{l}\text { DP } \\
\text { DO }\end{array}$ & $\begin{array}{l}\text { HYDRO } \\
\text { HYOPO }\end{array}$ & $\begin{array}{l}3 \\
3\end{array}$ & & & & & & \\
\hline & $D R$ & KACHINA & ic & LOON & $c$ & SETUP & $10 C^{\circ}$ & GYIIRO & $5 C$ \\
\hline & $\begin{array}{l}\text { OROU } \\
\text { ORO? }\end{array}$ & $\begin{array}{l}\text { HYOHO } \\
\text { KACHINA }\end{array}$ & ${ }^{3} \mathrm{c}$ & LOOP & $c$ & & & & \\
\hline & DRSO & KACHINA & c & Loop" & $c^{2}$ & $\begin{array}{l}\text { SETUP } \\
\text { SETUP }\end{array}$ & ic & HYORO & If \\
\hline $\mathbf{s}$ & DRV & $H^{Y}$ DRO & 2 & & & & & & \\
\hline & DS & HYUHO & 3 & & & & & & \\
\hline & DT & KACHINA & c & LOOP & $c$ & SEIUP & $8 C$ & HYDno & $15 C$ \\
\hline & DTK & HYURO & 36 & & & & & & \\
\hline & DTKBC & HYLIHO & 3 & & & & & & \\
\hline & DTKDE & HYORO & 3 & & & & & & \\
\hline & DTKDU & HYOHO & 3 & & & & & & \\
\hline & DTKDV & WYDRO & 3 & & & & & & \\
\hline & $\begin{array}{l}\text { DTKR } \\
\text { DTKRS }\end{array}$ & $\begin{array}{l}\text { KACHINA } \\
\text { HYDRO }\end{array}$ & $3^{0}$ & SETUP & $D$ & HYIJHO & 100 & & \\
\hline & DTKT & KACHINA & 0 & SETUP & 0 & HYUR & $8 D$ & & \\
\hline & DTo & KACHINA & c & LoON & c & SETUP & $3 \mathrm{C}$ & HYOHO & \\
\hline & DToc & KACHINA & c & LoOH & c & $S E T U_{P}$ & $2 c$ & HYORO & ${ }_{2}^{2 C}$ \\
\hline & $\begin{array}{l}\text { DTODR } \\
\text { DTODZ }\end{array}$ & $\begin{array}{l}\text { KACHIHA } \\
\text { KACH!HUA }\end{array}$ & c & $\begin{array}{l}\text { LOOP } \\
\text { LOOP }\end{array}$ & c & SETUF & $2 c$ & HYARO & $3 \mathrm{C}$ \\
\hline & DTO? & KACHINA & $c$ & LOOP & c & SE TUP & ic & $\begin{array}{l}\text { ArDRn } \\
\text { HYOPO }\end{array}$ & $\begin{array}{r}14 C \\
5 C\end{array}$ \\
\hline & $\begin{array}{l}\text { DTPOS } \\
\text { OZ }\end{array}$ & KACHINA & c & Lonp & $\mathrm{c}$ & SETUD & ic & HYORO & $\begin{array}{l}5 c \\
2 C\end{array}$ \\
\hline & $\mathrm{OZOZ}_{2}$ & KACHINA & ec & Lonp & c & SETUR & $7 \mathrm{C}$ & HYORO & $6 C$ \\
\hline & 0250 & KAC.HINA & c & Lonp & c & SE TUP & $\begin{array}{l}\text { Ic } \\
3 c\end{array}$ & $\begin{array}{l}\text { HYDRO } \\
\text { HYOHO }\end{array}$ & c \\
\hline & 01 & KACHJUA & 16 & LONP & $\bar{c}$ & SETUP & $c$ & HYORO & ${ }_{6 C}^{C}$ \\
\hline $\mathbf{S}$ & $\begin{array}{l}\text { E } \\
\text { EHPTY }\end{array}$ & KACHINA & $1^{0}$ & $\begin{array}{l}\text { SETUP } \\
\text { HYDHO }\end{array}$ & $2^{0}$ & HYORO & 50 & & \\
\hline & EMIO & KACHINA & $c$ & LOOP & ${ }^{2} c$ & SEIUP & & & \\
\hline & $\begin{array}{l}\text { EMS } \\
\text { EMG }\end{array}$ & $\begin{array}{l}\text { KACHIHA } \\
\text { KACHINAA }\end{array}$ & $\mathrm{c}$ & $\begin{array}{l}\text { LOUP } \\
\text { LOOP }\end{array}$ & $\begin{array}{l}c \\
c \\
c\end{array}$ & $\begin{array}{l}\text { SETUP } \\
\text { SE TUP }\end{array}$ & $\begin{array}{l}35 \\
\text { ic } \\
\text { ic }\end{array}$ & $\begin{array}{l}\text { AYDRO } \\
\text { HYJPO } \\
\text { HYDPO }\end{array}$ & $\begin{array}{c}8 \mathrm{C} \\
\mathrm{C}\end{array}$ \\
\hline & $\begin{array}{l}\text { ENYRY } \\
\text { EPD }\end{array}$ & $\begin{array}{l}\text { LOOP } \\
\text { KACHINA }\end{array}$ & 9 & & & & & & \\
\hline & EPS & KACHINA & c. & $\begin{array}{l}\text { SEIUP } \\
\text { LDUP }\end{array}$ & 20 & HYDKO & $D$ & & \\
\hline & EPV & KACHIHA & Co & Loor & $\begin{array}{l}c \\
c\end{array}$ & $\begin{array}{l}\text { SEIUP } \\
\text { SEIUP }\end{array}$ & $\begin{array}{l}2 C \\
2 C D\end{array}$ & $\begin{array}{l}\text { HYORO } \\
\text { HYDRO }\end{array}$ & ]$_{30}^{C}$ \\
\hline & $\begin{array}{l}\text { EPIO } \\
\text { EPZO }\end{array}$ & $\begin{array}{l}\text { KACHINA } \\
\text { KACHINA }\end{array}$ & c & $\begin{array}{l}\text { LOOP } \\
\text { LOOP }\end{array}$ & $=$ & SEIUP & $2 \mathrm{C}$ & HYURO & $\begin{array}{l}2 C 10 \\
2 C\end{array}$ \\
\hline & EPQ & KACHINA & $\ddot{c}$ & Lonp & E & SEYUP & $\begin{array}{l}1 \mathrm{C} \\
1 \mathrm{c}\end{array}$ & $\begin{array}{l}\text { HYORO } \\
\text { HYORO }\end{array}$ & 20 \\
\hline $\mathbf{F}$ & $\begin{array}{l}\text { EOUIVAL } \\
\text { ES }\end{array}$ & $\begin{array}{l}\text { KACHINA } \\
\text { HYDRO }\end{array}$ & 3 & SETUP & & HYOHO & & & \\
\hline & 5180 & KAC,HIHA & 0 & SETUP & 0 & HYORO & 70 & & \\
\hline & $\begin{array}{l}\text { FIBAR } \\
\text { FILM }\end{array}$ & $\begin{array}{l}\text { KACHINA } \\
\text { KAC,HINA }\end{array}$ & $2^{c}$ & L000 & & & 3 & HYURO & IC \\
\hline & $F 1 \times L$ & KACHINA & $c$ & Lor & & SETUP & $3 C$ & HYDRO & $5 c$ \\
\hline & FIYB & $\begin{array}{l}\text { KACHINA } \\
\text { KACHINAA }\end{array}$ & $c$ & $\begin{array}{l}\text { LOOD } \\
\text { LOOP }\end{array}$ & c & SE IINP & $3 c$ & HYORO & $c$ \\
\hline & PYY & KACHINAA & c & Lonp & c & SETUP & $\begin{array}{l}3 C \\
3 C\end{array}$ & $\begin{array}{l}\text { AYDQO } \\
\text { HYDRO }\end{array}$ & $5 C$ \\
\hline & $\begin{array}{l}\text { FJBAR } \\
\text { FL.OAT } \\
\text { FNB }\end{array}$ & $\begin{array}{l}\text { KACHINA } \\
\text { SE TUP } \\
\text { SE TUP }\end{array}$ & $9^{c}$ & $\begin{array}{l}\text { LOOP } \\
\text { HYINHO }\end{array}$ & ${ }_{\theta}^{C}$ & SE UUP & $3 c$ & HYDRO & \\
\hline
\end{tabular}




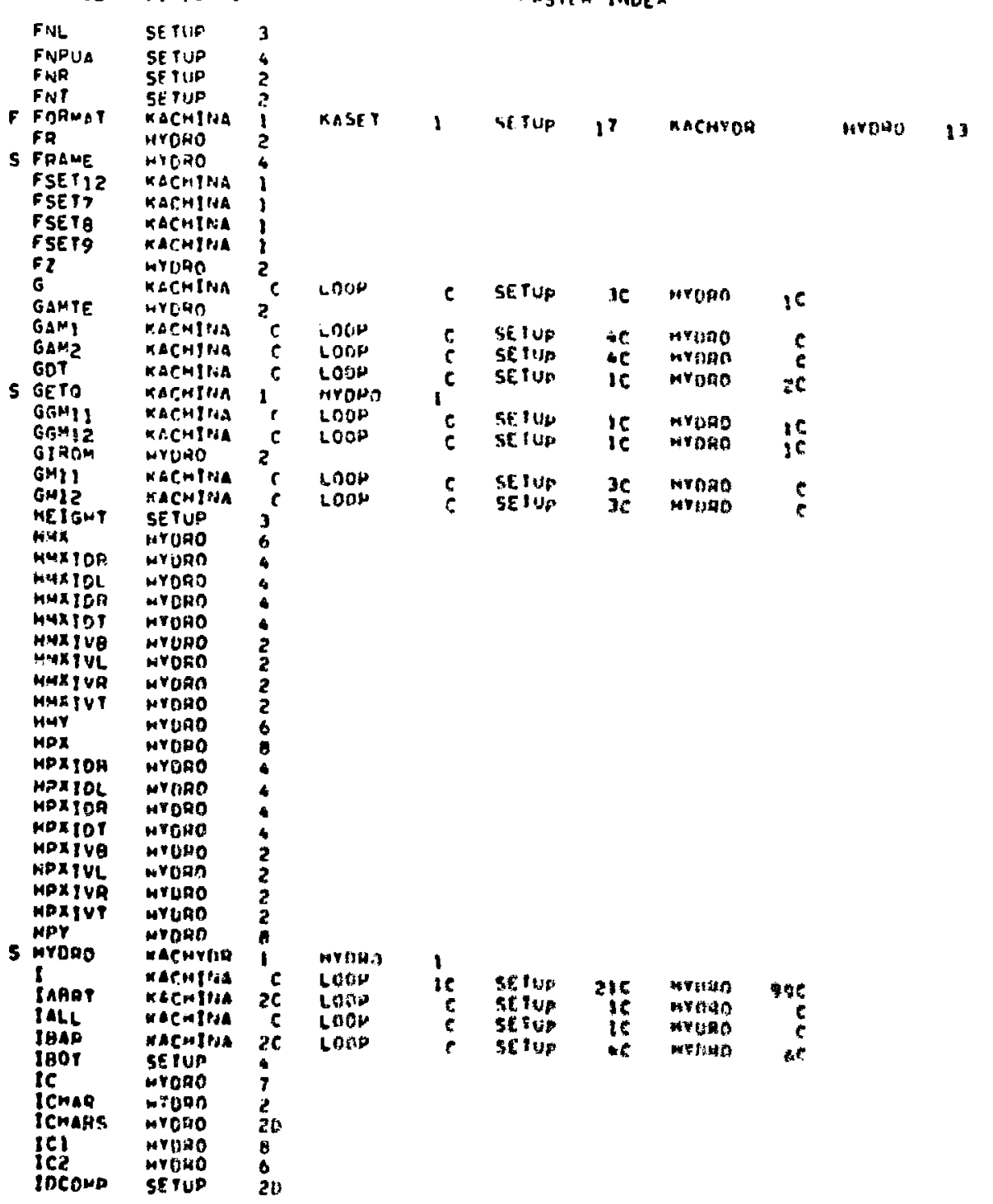




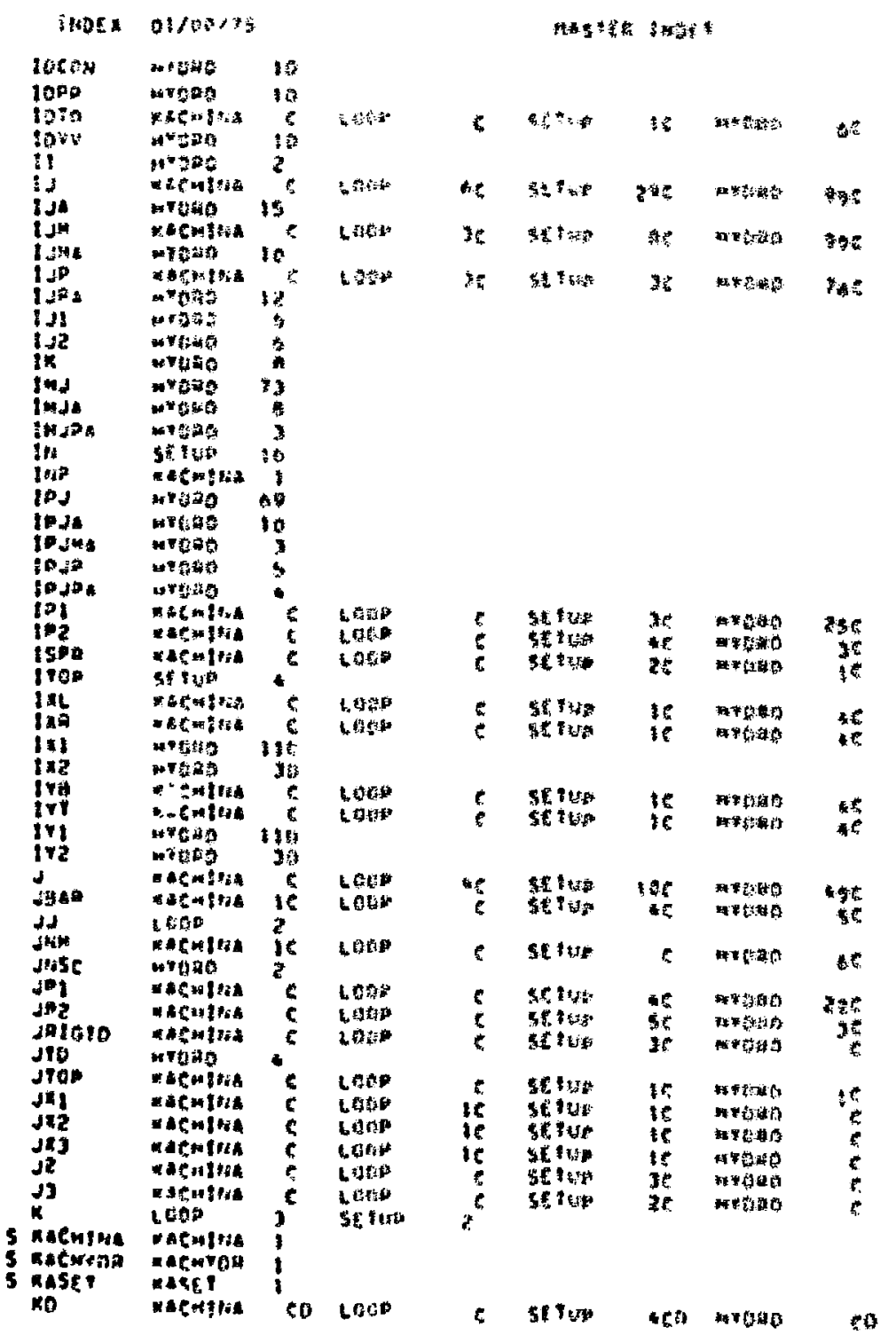


IwOEX 01/00/75

Hastra bnuex

\begin{tabular}{|c|c|c|c|c|c|c|c|c|}
\hline $\begin{array}{l}\text { K000R5n } \\
\text { K0C0258 }\end{array}$ & $\begin{array}{l}\text { KACHIPIA } \\
\text { KACHINA }\end{array}$ & $\begin{array}{l}\mathrm{CO} \\
\mathrm{CO}\end{array}$ & $\begin{array}{l}\text { LOCO } \\
\text { LCOP }\end{array}$ & c & $\begin{array}{l}\text { SETUP } \\
\text { SETUP }\end{array}$ & sea & wroso & 100 \\
\hline $\begin{array}{l}\text { KE } \\
\text { KELG } \\
\text { KIJ }\end{array}$ & $\begin{array}{l}\text { SEYUP } \\
\text { WYOPO } \\
\text { KACHINA }\end{array}$ & $3_{0}^{10}$ & & & & 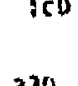 & & $\operatorname{icn}$ \\
\hline & $\begin{array}{l}\text { RACHINA } \\
\text { LOGP } \\
\text { SE YUP }\end{array}$ & $2_{2}^{D}$ & SETUP & $n$ & hroso & 230 & & \\
\hline $\begin{array}{l}\text { KHA I } \\
\text { KHATS }\end{array}$ & SE TUP & 2 & HYOHO & 6 & & & & \\
\hline $\begin{array}{l}\text { KHATS } \\
\text { KP }\end{array}$ & $\begin{array}{l}\text { SE TUP } \\
\text { WYDAO }\end{array}$ & 10 & IYDPO & 10 & & & & \\
\hline KPN & HYURO & 6 & & & & & & \\
\hline $\begin{array}{l}\text { KREO } \\
\text { KRET }\end{array}$ & $\begin{array}{l}\text { HYOHO } \\
\text { SETUP }\end{array}$ & 14 & WYOAO & 3 & & & & \\
\hline KAF & MYURO & 6 & & 5 & & & & \\
\hline $\begin{array}{l}\text { KRFD } \\
\text { KROUT }\end{array}$ & $\begin{array}{l}\text { FYURO } \\
\text { KYORO }\end{array}$ & $\begin{array}{l}3 \\
3\end{array}$ & & & & & & \\
\hline KRP & WYORO & 4 & & & & & & \\
\hline $\begin{array}{l}K R ! \\
K S B\end{array}$ & HYONO & 5 & & & & & & \\
\hline $\begin{array}{l}\mathrm{ksB} \\
\mathrm{kSC}\end{array}$ & $\begin{array}{l}\text { KACHINA } \\
\text { KACMIAUA }\end{array}$ & 1 & LOOP & 1 & SETUK & 1 & MYDAO & 1 \\
\hline $\mathrm{KT}$ & SE TUP & 11 & LOOP & $\mathbf{i}$ & SETUP & 1 & mYORO & 1 \\
\hline & KACHINA & CD & LOON & c & SEIUD & 400 & FYORD & co \\
\hline $\begin{array}{l}\text { KVOORSO } \\
\text { KVODZSO }\end{array}$ & $\begin{array}{l}\text { KACHINA } \\
\text { KACHINA }\end{array}$ & $\begin{array}{l}C D \\
C D\end{array}$ & $\begin{array}{l}\text { LOOP } \\
\text { LOOP }\end{array}$ & $c$ & $\begin{array}{l}\text { SEIUP } \\
\text { SETUP }\end{array}$ & $\begin{array}{l}\text { ICO } \\
\text { ico }\end{array}$ & $\begin{array}{l}\text { MYORO } \\
\text { HYPRO }\end{array}$ & ICO \\
\hline $\begin{array}{l}K \bar{l} \\
k \dot{2}\end{array}$ & $\begin{array}{l}\text { MYURO } \\
\text { WYORO }\end{array}$ & 6 & & & & & & \\
\hline $\begin{array}{l}k_{2} \\
k_{3}\end{array}$ & HYORO & $\begin{array}{l}8 \\
6\end{array}$ & & & & & & \\
\hline$K_{4}$ & $\begin{array}{l}\text { MYDRO } \\
\text { HYDRO }\end{array}$ & $\begin{array}{r}6 \\
49\end{array}$ & & & & & & \\
\hline LCM & KACHINA & c & LOOP & 16 & SEIUp & 16 & HYORO & C \\
\hline $\begin{array}{l}\text { LCMFLG } \\
\text { LINCNT }\end{array}$ & $\begin{array}{l}\text { LOOP } \\
\text { MYDRO }\end{array}$ & $\begin{array}{l}1 \\
5\end{array}$ & SETUP & $i$ & & 16 & & $2 C$ \\
\hline $\begin{array}{l}\text { LINESF } \\
\text { LINESP }\end{array}$ & $\begin{array}{l}\text { HYORO } \\
\text { MYOHOO }\end{array}$ & 4 & & & & & & \\
\hline & MYDRO & 7 & & & & & & \\
\hline $\begin{array}{l}\text { LMI } \\
\text { LOCF }\end{array}$ & $\begin{array}{l}\text { HYURO } \\
\text { SEYUP }\end{array}$ & 3 & HYRP & $?$ & & & & \\
\hline $\begin{array}{l}\text { LOOP } \\
\text { LPR }\end{array}$ & $\begin{array}{l}\text { LOOP } \\
\text { KACHINA }\end{array}$ & $i_{c}$ & $\begin{array}{l}\text { SETUP } \\
\text { LOOP }\end{array}$ & 2 & HYORO & 22 & & \\
\hline MusY1T & HYDRO & 12 & & & SETUP & & MYORO & 126 \\
\hline $\begin{array}{l}\text { MUSTPR } \\
\text { MUSTPO } \\
\text { N }\end{array}$ & $\begin{array}{l}\text { KACHINA } \\
\text { KACHINA } \\
\text { SETUP }\end{array}$ & ${ }_{12}^{c}$ & $\begin{array}{l}\text { LOOP } \\
\text { LOOP } \\
\text { HYORO }\end{array}$ & ${ }_{8}^{C}$ & $\begin{array}{l}\text { SETUP } \\
\text { SETUP }\end{array}$ & c & $\begin{array}{l}\text { HYORO } \\
\text { AYDRO }\end{array}$ & $\begin{array}{l}3 C \\
4 C\end{array}$ \\
\hline $\begin{array}{l}\text { NAME } \\
\text { NB } \\
\text { Naz }\end{array}$ & $\begin{array}{l}\text { KACHINA } \\
\text { SEYUP } \\
\text { SETUP }\end{array}$ & ${ }^{5}$ & LOQP & c & SETUP & $2 c$ & HYDAO & $B C$ \\
\hline $\begin{array}{l}\text { NCYC } \\
\text { NFA } \\
\text { NL }\end{array}$ & $\begin{array}{l}\text { KACMINA } \\
\text { HYDRO } \\
\text { SETUP }\end{array}$ & $\begin{array}{l}4^{c} \\
5\end{array}$ & LOOP & c & SETUP & IC & HYORO & $20 \mathrm{C}$ \\
\hline $\begin{array}{l}\text { NLC } \\
\text { NLE } \\
\text { No }\end{array}$ & $\begin{array}{l}\text { KACHINA } \\
\text { SETUP } \\
\text { HYDRO }\end{array}$ & $\begin{array}{l}2^{C} \\
8\end{array}$ & LONP & $c$ & SETUp & 1C & MYDRO & $2 c$ \\
\hline $\begin{array}{l}\text { NPTOT } \\
\text { NPUA } \\
\text { NPX } \\
\text { NPY }\end{array}$ & $\begin{array}{l}\text { KACHINA } \\
\text { SETUP } \\
\text { SETUP } \\
\text { GETUP }\end{array}$ & $5^{C}$ & LOOP & $c$ & SETUP & PC & HYORO & $6 \mathrm{C}$ \\
\hline
\end{tabular}




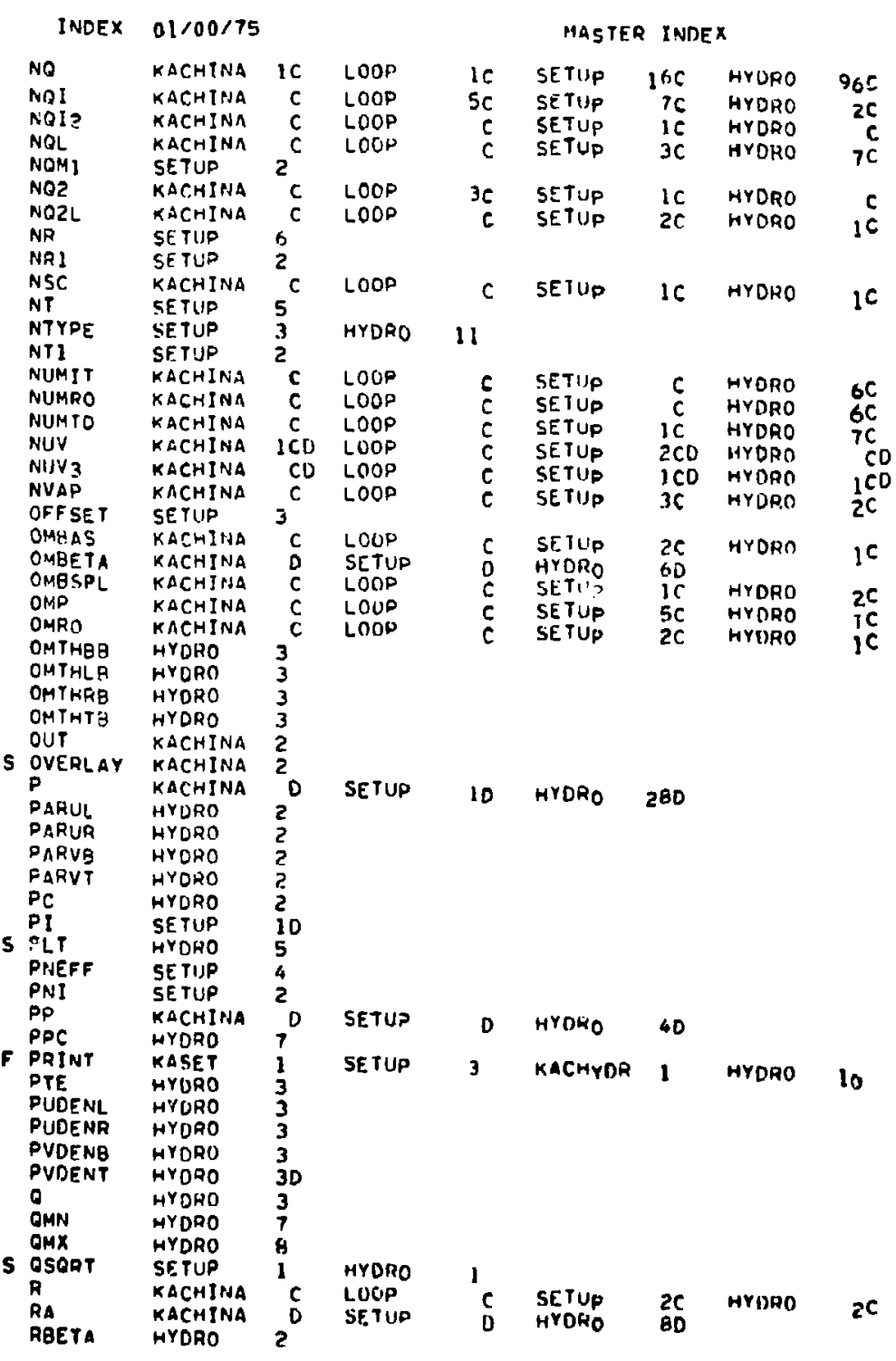




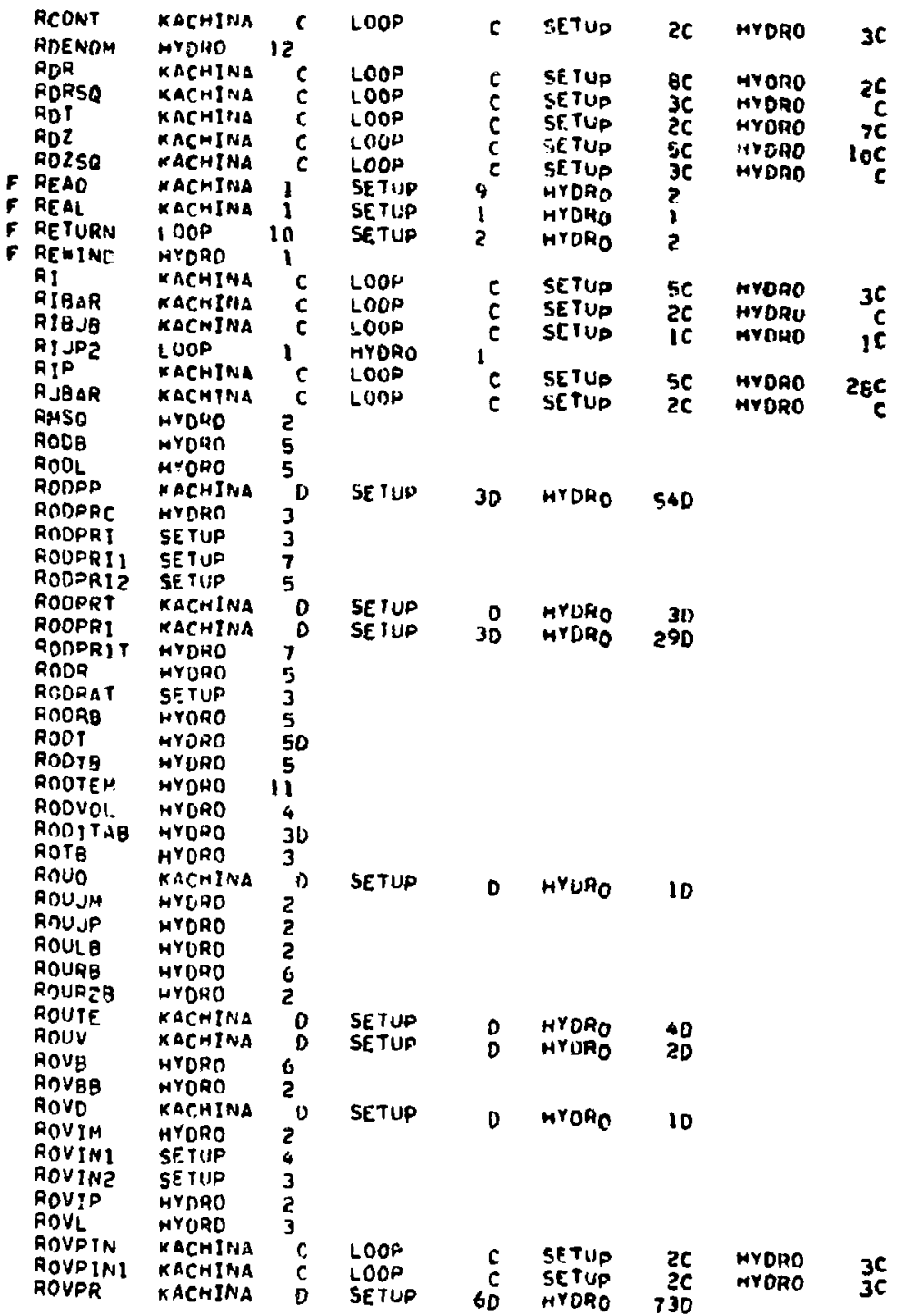




\begin{tabular}{|c|c|c|c|c|c|c|c|c|}
\hline \multirow{2}{*}{$\begin{array}{l}\text { INDEX } \\
\text { ROVPRI }\end{array}$} & \multicolumn{2}{|l|}{$01 / 00 / 75$} & & \multicolumn{2}{|r|}{ Master } & INDEX & & \\
\hline & SETUP & 4 & & & & & & \\
\hline ROVPRII & $\begin{array}{l}\text { SETUP } \\
\text { SETUP }\end{array}$ & 5 & & & & & & \\
\hline $\begin{array}{l}\text { ROVPRI2 } \\
\text { ROVPRT }\end{array}$ & $\begin{array}{l}\text { SETUP } \\
\text { KACHINA }\end{array}$ & ${ }^{3} 0$ & SETUP & & HYDRO & & & \\
\hline AOVDRTC & HYDHO & 6 & & D & & 210 & & \\
\hline $\begin{array}{l}\text { ROVPRTN } \\
\text { ROVPRTO }\end{array}$ & HYDRO & 14 & & & & & & \\
\hline $\begin{array}{l}\text { ROVPRTO } \\
\text { ROVPRI }\end{array}$ & $\begin{array}{l}\text { HYDHO } \\
\text { KACMINA }\end{array}$ & 10 & SETUP & & & & & \\
\hline $\begin{array}{l}\text { ROVPRI } \\
\text { ROVPRIT } \\
\text { ROVPRZ }\end{array}$ & $\begin{array}{l}\text { KACHINA } \\
\text { KACH!NA }\end{array}$ & $\begin{array}{l}D \\
D\end{array}$ & SETUP & $\begin{array}{r}6 D \\
D\end{array}$ & $\begin{array}{l}\text { HYDRO } \\
\text { HYORO }\end{array}$ & $\begin{array}{l}310 \\
230\end{array}$ & & \\
\hline $\begin{array}{l}\text { ROVPRZ } \\
\text { ROVR } \\
\text { ROVRBN }\end{array}$ & $\begin{array}{l}\text { HYDRO } \\
\text { HYDRO }\end{array}$ & $\begin{array}{l}3 \\
3\end{array}$ & & & & & & \\
\hline $\begin{array}{l}\text { ROVRBN } \\
\text { ROVRBO }\end{array}$ & $\begin{array}{l}\text { HYDRO } \\
\text { HYORO }\end{array}$ & 3 & & & & & & \\
\hline $\begin{array}{l}\text { ROVSPL } \\
\text { ROVT }\end{array}$ & KACHINA & $D$ & SETUP & D & HYDRO & 1D & & \\
\hline $\begin{array}{l}\text { ROVT } \\
\text { ROVIB }\end{array}$ & HYORO & 3 & & 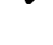 & & 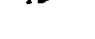 & & \\
\hline $\begin{array}{l}\text { ROVIB } \\
\text { ROVIBN } \\
\text { ROVTBO }\end{array}$ & $\begin{array}{l}\text { HYDRD } \\
\text { HYDRO }\end{array}$ & $\begin{array}{l}6 \\
3\end{array}$ & & & & & & \\
\hline $\begin{array}{l}\text { ROVTRO } \\
\text { RDVTE }\end{array}$ & HYDRO & 2 & & & & & & \\
\hline $\begin{array}{l}\text { ROVTE } \\
\text { ROVTEM }\end{array}$ & KACHINA & $D$ & SETUP & 0 & HYDFO & $7 D$ & & \\
\hline $\begin{array}{l}\text { ROVTEM } \\
\text { ROVT28 }\end{array}$ & $\begin{array}{l}\text { HYORO } \\
\text { HYOAO }\end{array}$ & $\begin{array}{l}9 \\
2\end{array}$ & & & & & & \\
\hline $\begin{array}{l}\text { ROVN } \\
\text { ROVYOL }\end{array}$ & KACHINA & $D$ & SETIJP & $D$ & HYDRO & 30 & & \\
\hline $\begin{array}{l}\text { ROVYOL } \\
\text { ROVO }\end{array}$ & HYORO & 4 & & & & & & \\
\hline $\begin{array}{l}\text { ROV } \\
\text { ROV V }\end{array}$ & $\begin{array}{l}\text { KACHINA } \\
\text { SETUP }\end{array}$ & 16 & LOOP & C & SETUP & 16 & HYDRO & $2 C$ \\
\hline Rove & SETUP & 5 & & & & & & \\
\hline Ro1 & KACHINA & C & LOOP & c & SETUP & 36 & HYORO & $c$ \\
\hline $\mathrm{ROZ}$ & KACHIPNA & c & LOOP & 6 & SETUP & 36 & MYURO & $a$ \\
\hline RPAR & KAGHINA & ic & $\angle 000$ & $c$ & SETUP & $3 c$ & HYDRO & c \\
\hline $\begin{array}{l}\text { RPARU } \\
\text { RPARU }\end{array}$ & LOOP & 1 & HYDRO & 3 & & & & \\
\hline $\begin{array}{l}\text { RPARV } \\
\text { RPCDR }\end{array}$ & $\begin{array}{l}\text { LONP } \\
\text { KACHINA }\end{array}$ & ${ }^{1}{ }_{c}$ & $\begin{array}{l}\text { HYORO } \\
\text { LOOP }\end{array}$ & ${ }^{1} \mathrm{c}$ & SETUP & IC & MYDRO & \\
\hline $\begin{array}{l}\text { RPCOF } \\
\text { RP }\end{array}$ & $\begin{array}{l}\text { ZACHINA } \\
\text { WYDRO }\end{array}$ & $6^{c}$ & LOOP & $c$ & SETUP & IC & WYORO & 16 \\
\hline$R Q_{1}$ & KACHINA & c & LOOP & $c$ & SETUP & $4 C$ & MYDRO & \\
\hline $\begin{array}{l}\text { RRIOR } \\
\text { RRIP }\end{array}$ & KACHINA & $\mathrm{c}$ & LOOP & c & SEYUP & $2 c$ & HYDHO & BC \\
\hline RRIP & KACHINA & 6 & LOOP & c & SETUP & $2 C$ & HYURO & ic \\
\hline RROI & KACHINA & $c$ & LOOP & $c$ & SETUP & $2 C$ & HYDRO & je \\
\hline $\begin{array}{l}\text { AR02 } \\
\text { RS }\end{array}$ & $\begin{array}{l}\text { KACHINA } \\
\text { HYDRO }\end{array}$ & $3^{C}$ & LOOP & $i$ & SETUP & $2 c$ & MYDRO & ic \\
\hline $\begin{array}{l}\text { RIROW } \\
\text { R2A }\end{array}$ & $\begin{array}{l}\text { LOOP } \\
\text { HYDRO }\end{array}$ & $\begin{array}{l}1 \\
5\end{array}$ & SETUP & 1 & & & & \\
\hline $\begin{array}{l}A_{2 A} \\
R_{22 D R} \\
8207\end{array}$ & KACHINA & c & LONP & & SETUP & 16 & HYORO & $2 c$ \\
\hline $\begin{array}{l}\text { REDZ } \\
\text { SE }\end{array}$ & KACHINA & C & LODP & $\mathrm{C}$ & SEIUP & 10 & HYDnO & $2 c$ \\
\hline $\begin{array}{l}\text { SE } \\
\text { SECOND }\end{array}$ & $\begin{array}{l}\text { HYORO } \\
\text { HYORD }\end{array}$ & 20 & & & & & & \\
\hline $\begin{array}{l}\text { SED } \\
\text { SET; J }\end{array}$ & HYDRO & 20 & & & & & & \\
\hline $\begin{array}{l}\text { SETiJ } \\
\text { S SETUP }\end{array}$ & LOOP & 1 & SETUO & 1 & & & & \\
\hline 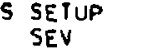 & $\begin{array}{l}\text { KASET } \\
\text { HYDRO }\end{array}$ & 1 & SETUP & $\mathbf{i}$ & & & & \\
\hline SIEO & KACHINA & 0 & SETUP & 30 & HYORO & 180 & & \\
\hline $\begin{array}{l}\text { SIEDC } \\
\text { SIEOEL }\end{array}$ & $\begin{array}{l}\text { HYDRO } \\
\text { HYURO }\end{array}$ & $\begin{array}{l}8 \\
4\end{array}$ & & & & & & \\
\hline $\begin{array}{l}\text { SIEDT } \\
\text { SIEDTAB }\end{array}$ & $\begin{array}{l}\text { SETUP } \\
\text { HYDRO }\end{array}$ & 30 & & & & & & \\
\hline SIEOTE & HYDRO & 5 & & & & & & \\
\hline
\end{tabular}




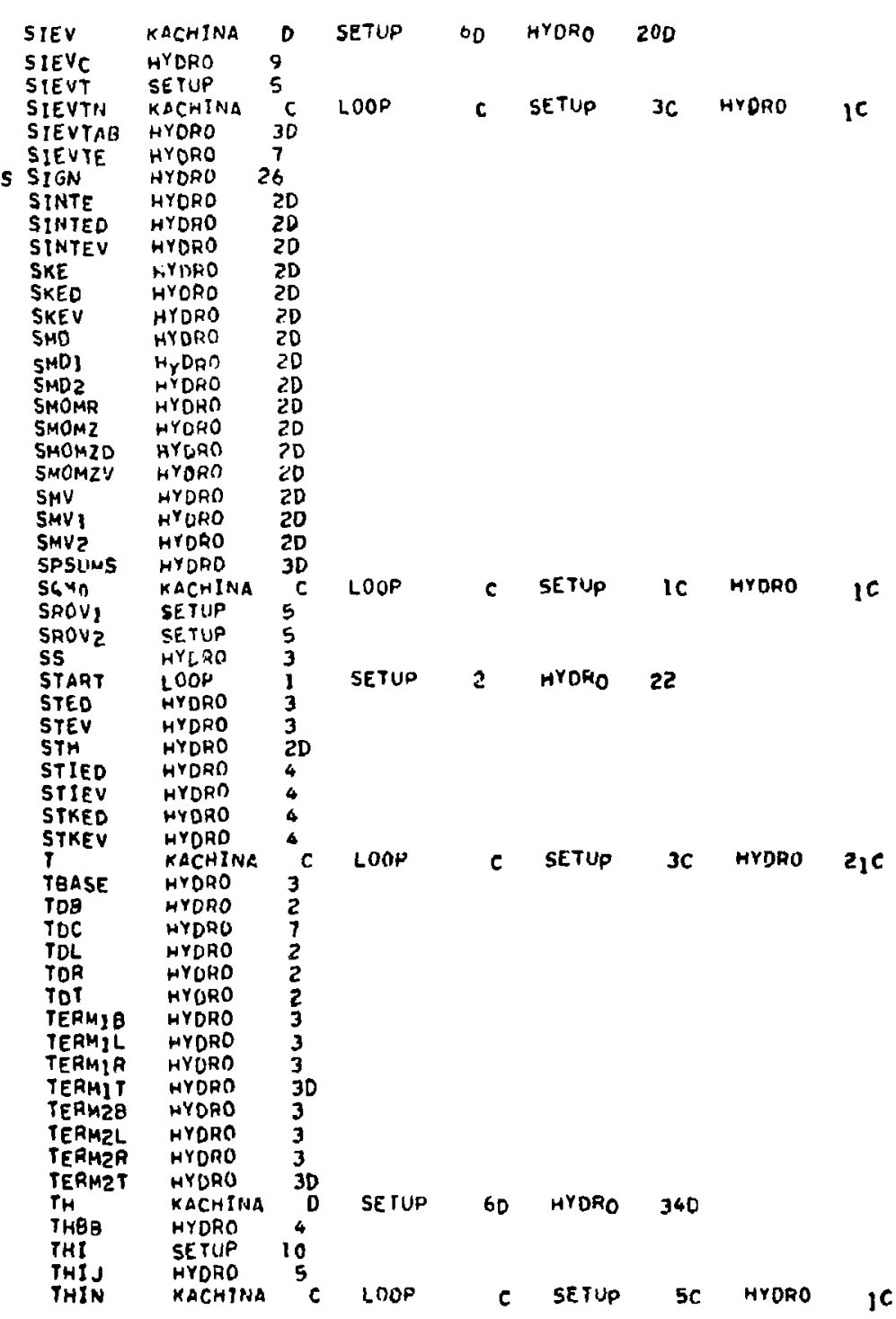




\begin{tabular}{|c|c|c|c|c|c|c|c|c|}
\hline INOEX & $01 / 00 / 75$ & & & & MASIER & IND & & \\
\hline THLB & WYORO & 4 & & & & & & \\
\hline THRB & WYORO & 7 & & & & & & \\
\hline THTAB & HYORO & 30 & & & & & & \\
\hline THTB & HYDRO & 7 & & & & & & \\
\hline THTE & HYDRO & 20 & & & & & & \\
\hline THTEB & HYDRE & 5 & & & & & & \\
\hline THTEC & NYORO & 3 & & & & & & \\
\hline THTEL & HYORO & 5 & & & & & & \\
\hline $\begin{array}{l}\text { THTER } \\
\text { THTERM }\end{array}$ & $\begin{array}{l}\text { HYORO } \\
\text { HYDRO }\end{array}$ & 5 & & & & & & \\
\hline THTESO & HYDRO & 3 & & & & & & \\
\hline THTET & HYURO & 50 & & & & & & \\
\hline TLIM & $\begin{array}{l}\text { KACHINA } \\
\text { HYORO }\end{array}$ & ${ }_{6}^{C}$ & LOOP & c & SETUP & 16 & HYORO & $a c$ \\
\hline $\begin{array}{l}\text { TLIMD } \\
\text { TOLO }\end{array}$ & $\begin{array}{l}\text { KACHINA } \\
\text { HYDRO }\end{array}$ & $\begin{array}{r}c \\
20\end{array}$ & LOOP & C & SETUP & $2 C$ & HYORC & 26 \\
\hline TOP & KACHINA & $\mathrm{c}$ & LOOP & c & SETUP & & & \\
\hline $\begin{array}{l}\text { TOUT } \\
\text { TYg }\end{array}$ & KACHINA & c & LOUP & c & SETUP & 10 & HYDRO & $\begin{array}{l}3 C \\
6 C\end{array}$ \\
\hline TVC & $\begin{array}{l}\text { HYORO } \\
\text { HYDRO }\end{array}$ & $\frac{2}{7}$ & & & & & & \\
\hline TVL & HYDFO & 2 & & & & & & \\
\hline TVR & HYORO & 2 & & & & & & \\
\hline $\begin{array}{l}\text { TVT } \\
\text { THF IN }\end{array}$ & $\begin{array}{l}\text { WYORO } \\
\text { KACHINA }\end{array}$ & ${ }^{2} c$ & & & & & & \\
\hline $\begin{array}{l}15 \\
15\end{array}$ & $\begin{array}{l}\text { HYDRO } \\
\text { HYDRO }\end{array}$ & $\begin{array}{l}3^{C} \\
80\end{array}$ & LOOP & C & SETUP & 26. & HYDRO & IC \\
\hline $\begin{array}{l}\text { TzOMO } \\
\text { UE }\end{array}$ & $\begin{array}{l}\text { KACHINA } \\
\text { HYORO }\end{array}$ & ${ }_{4}^{C}$ & LOOP & C & SETUP & $2 c$ & HYDRO & JC \\
\hline UD & KACHINA & 0 & SETUP & D & HYORO & 320 & & \\
\hline $\begin{array}{l}\text { UDRL } \\
\text { URRP }\end{array}$ & HYDRO & 4 & & & & & & \\
\hline UDTE & HYDRO & 3 & & & & & & \\
\hline UK & HYDRO & 2 & & & & & & \\
\hline UA & HYORO & 4 & & & & & & \\
\hline URB & HYDRO & 6 & & & & & & \\
\hline US & HYDRO & 3 & & & & & & \\
\hline UTB & HYDRO & 3 & & & & & & \\
\hline UTLC & HYORO & 5 & & & & & & \\
\hline UTRE & HYDRO & 5 & & & & & & \\
\hline Uv & KACHINA & D & SETUP & D & HYORO & 570 & & \\
\hline UVL & HYDRO & 3 & & 0 & & gro & & \\
\hline UVR & $\begin{array}{l}\text { HYORO } \\
\text { HYDRO }\end{array}$ & 8 & & & & & & \\
\hline UVAR & WYORO & 8 & & & & & & \\
\hline UVRL & HYORO & 2 & & & & & & \\
\hline UVRE & HYDRO & 2 & & & & & & \\
\hline UVTE & WYORO & 3 & & & & & & \\
\hline $\begin{array}{l}\text { VQRC } \\
\text { ve }\end{array}$ & $\begin{array}{l}\text { HYORO } \\
\text { HYDRO }\end{array}$ & $\begin{array}{l}5 \\
4\end{array}$ & & & & & & \\
\hline VCON & SETUP & 3 & & & & & & \\
\hline Vo & KACGIINA & 0 & SETUP & 0 & HYDRO & 400 & & \\
\hline VDTE & HYDRO & 3 & & & & & & \\
\hline $\begin{array}{l}\text { VECVEL. } \\
\text { VEL }\end{array}$ & $\begin{array}{l}\text { HYURO } \\
\text { HYDRO }\end{array}$ & $\frac{2}{7}$ & & & & & & \\
\hline VELMX & HYDRO & 170 & & & & & & \\
\hline & HYORO & 2 & & & & & & \\
\hline
\end{tabular}




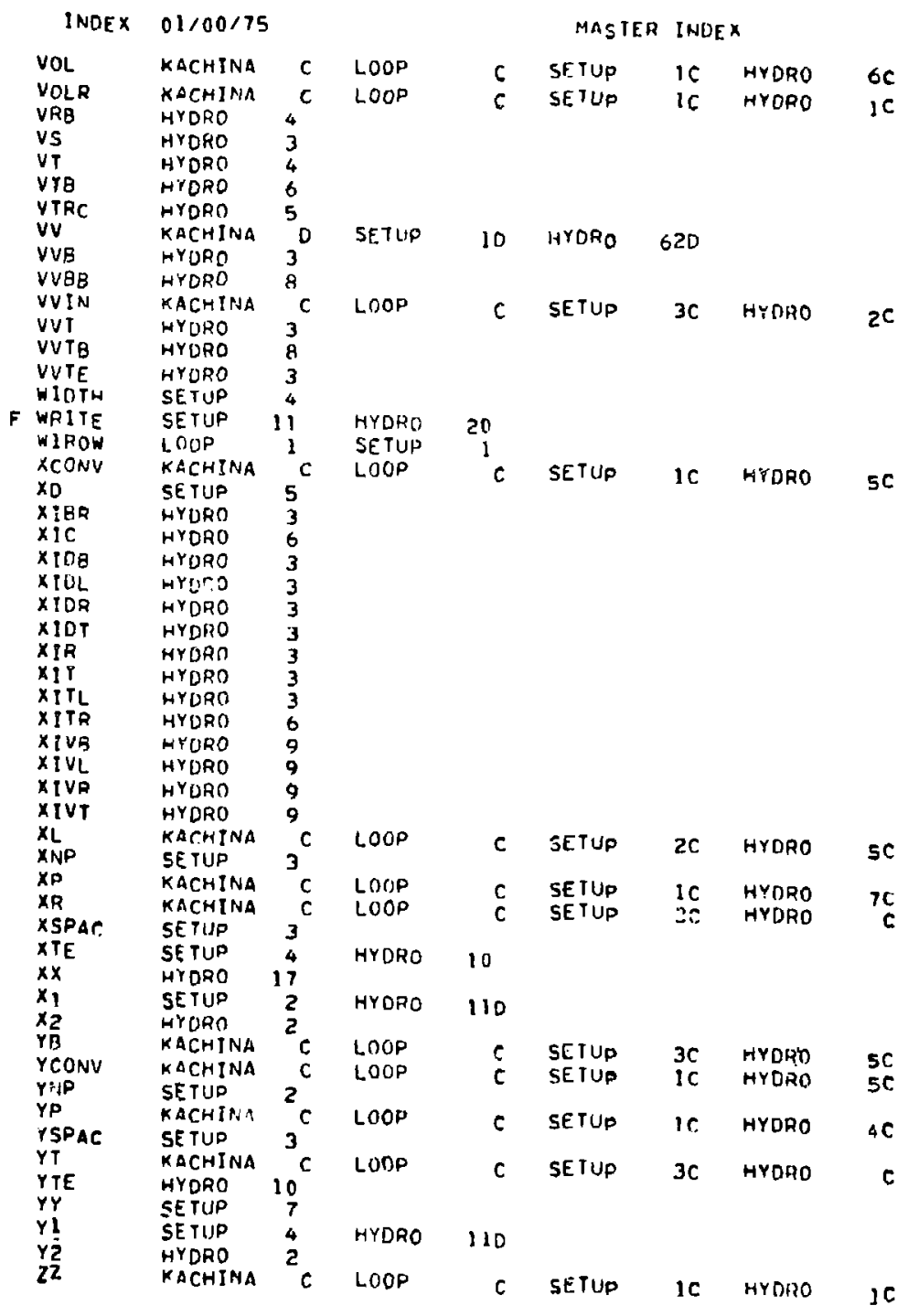


RGUTINES INDEXEO ROUTINE PAGE ROUTINE PAGE ROUTINE PAGE

DONE

ROUTINE PAGE

ROIIINE PAGE

ROUTINE PAGE

ROUTINE PAGE

ROUTINE PAGE

ROUTINE PAGE

HYDRO KACHINA
KACHYOR

KASET
LCMFLG

5 LOOP

5 P.PARU

RIROW

SETIJ

SETUP

10
5

WIRON

5

INDEX $01 / 00 / 75$

MASTER INDFX

PAGE 7

71

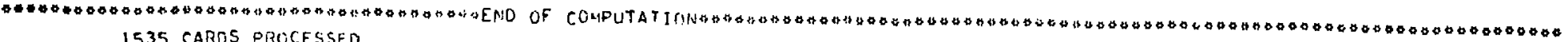

1535 CARDS PROCESSED

3086 MAXIMUM BUFFER USED BY ANY ROUTINE

2048 TOTAL ECS REQUIRED BY INDEX

5.868 SECONDS OF CP TIME USE 
APPENDIX C

MODIFICATIONS FOR ICM STORAGE OF CELL DATA

The bastc SCM version of KACHINA shown in Appendixes $A$ and $B$ has been purposely designed so that both the $(1,0)$ and $(2,0)$ overlays are completely compatitle with LCM usage and require no modifications in conversion to LCM storage of cell data. This limits the necessary changes to the following twc places in the $(0,0)$ overlay.

(1) Storage Definition. An LCM cell-storage block is defined, and the SCM buffer AASC is shortened and moved out of the main common KSC Into the scratchpad common KSB. Thus, the beginning of the storage definition card set reads as follows.

LCM/KLCl/AAL (131000)

COMMON/KSB/AASC(5814), AARDW(1938)

COMOSN/RSC/AA (1), AKINFI, AO, BDTODR, BDTØDZ,

(etc.)

The dimension of 5814 words for AASC allows any $\bar{I} \leqslant 100$ with $N Q=19$ words per cell. $\bar{J}$ is 1 imited only by avallable LCM.

(2) Cell Data Handing. The entire instruction part of SUBRØUTINE LOOP is replaced by the following version.

CALI. ECWR (AASC(JW), IECK, NQI, NE)

$\mathrm{IECW}=\mathrm{IECW}+\mathrm{NQI}$

GD TD $(10,20,30)$ IBUF

$10 \mathrm{JR}=1$

$\mathbf{J W}=\mathbf{J} \mathbf{2}$

$I . J P=J X 1$

$1 J=J \times 3$

$\mathrm{IJM}=\mathrm{J \times 2}$

IBUF $=2$

CO TO 40

$20 \mathrm{JR}=\mathrm{J} 2$

$\pi=33$

$\mathrm{IJ} \mathrm{JP}=\mathrm{JX} \mathbf{2}$

$\mathbf{I J}=\mathrm{JXI}$

$\mathrm{IJM}=\mathrm{J} \times 3$
IBUF $=3$

$G \emptyset T \emptyset 40$

ENTRY START

CALL ECRD (AASC, 0, NQI2, NE)

$\mathrm{IECR}=\mathrm{NQI2}$

$\mathrm{IECW}=0$

$30 \mathrm{JR}=\mathrm{J} 3$

$\mathrm{JW}=\mathrm{IBUF}=1$

$\mathrm{IJP}=\mathrm{JX} 3$

$\mathrm{I} \mathbf{J}=\mathbf{J X} 2$

$\mathrm{I} . \mathrm{M} \mathbf{M}=\mathbf{J X} \mathbf{I}$

40 CALL ECRD (AASC(JR), IECR, NQI, NE)

$\mathrm{IECR}=\mathrm{IECR}+\mathrm{NQI}$

RETURN

ENTRY IDONE

CALL ECWR (AASC(JW), IECW, NQI, NE)

$\mathrm{IECW}=\mathrm{IECW}+\mathrm{NQI}$

G $\emptyset$ T $(50,60,70)$ IBUF

$50 \mathrm{JW}=\mathrm{J} 2$

$G \emptyset \mathrm{T} \emptyset 0$

$60 \mathrm{JW}=\mathrm{J3}$

$\cos T 80$

$70 \mathrm{JW}=1$

80 CALL ECWR (AASC (JW), IECW, NQI, NE)

RETURN

ENTRY RIRGW

IEC $=(J-1) \star N Q I$

CALL ECRD (AASC, IEC, NQI,NE)

RETURN

ENTRY SETIJ

$\mathrm{IJ}=(\mathrm{I}-1) * \mathrm{NQ}+1$

RETURN

ENTRY WIRøW 
CALL ECWR (AASC, IEC, NQI,NE)

RETURN

ENTRY LCMFLG

$\mathrm{LCM}=1$

RETURN

ENTRY RIJP2

CAII ECRD (AARQW, IECR, NQI,NE)

RETURN

ENTRY RPARU

$\mathrm{IEC}=(\mathrm{J}-1) \star \mathrm{NQI}$

IJ $=0$

GDTO 300

ENTRY RQARY

$\mathrm{IEC}=(\mathrm{J}-2) * \mathrm{NQI}$

$\mathrm{IJ}=\mathrm{NQI}$

300 CALL ECRD (AASC, IEC, NQI2, NE)

RETURN

END

The SETUP and HYDR $\emptyset$ subroutines contain several peculfarities that are specially treated to nake them compatible with either SCM or LCM usage. The required modiflcations daserve some explanation.

(1) The routine that inftially sets all required cell-storage to zeros (DO loops 189 and 199 In SETUP) is designed to hand te elther SCM or LCM cell storage automatically without cesting.

(2) Note that the SCM version of ENTRY L $\$ \emptyset P$ advances the three row indices IJ, IJP, and IJM over two columns of cells $(1=\operatorname{IP} 2$ and $1=1)$, the assumption belng that the I Do loops normally encompass a 11 interior cells in the row $(1=2$ through $1=$ IP1). Several DQ loops in the code, however, have I DO loops with a lesser or greater range of columns, requiring some increment or decrement of these indices upon RETURN from $L \phi \phi P$, to keep the indexing properly phased.

In the $L C M$ version, though, such adjustments are unnecessary, as here LDDP inverlably sets IJ, IJP, and IJM to polnt to column $1=2$ cells. This distinction between the versions is handled automatically because the values of the increments or decremants used (NQL and NQ2L) are set to zero in SETUP in the LCM version. Again, this allows affected DQ loops to be fully general with no required testing of whether SCM or LCM Is being used.

In the present version, I D loops so treated are those with terminal statement numbers of 189 in SETUP, and $779,889,1539$, and 3189 in HYDR $\phi$. Remember that a similar treatment may be required if new code is constructed that has I Do loops with ranges other than the usual $i=2$ through $i=I F 1$.

(3) In the calculation of $\left(\overline{\rho^{\top} v}\right)_{1}^{j+\frac{1}{2}}$ in region 1550 in HYDR $\phi$, reference is made to $\frac{1}{\left(\rho^{\prime} v\right)}{ }_{1}^{j+3 / 2}$ to obtaln a donor cell term for the equation. Because this reference, in turn, involves the use of $\rho_{i}^{j+2}$, which is not available in the three rows that have been read from LCM, cell data from row $j+2$ must be read in separately. This is the responsibility of ENTRY RIJP2 in L $\emptyset P$. In the LCM verston, it simply reads in row $j+2$, whose address is specified by the current setting of the $L C M$ read Index, to the onesow buffer AAR $\$ W$. The statement in region 1550 that calculates $\left(\rho^{\prime} v\right)_{\hat{1}}^{j+3 / 2}$ (named $R \emptyset V T 2 B$ ) then references the dersity $\left(\rho^{\prime}\right) j_{1}^{j+2}$ (RøVSPL) from this one-row buffer.

The problem of referencing quantities in rows beyond $j+1$ and $j-1$ obviously doesn't exist in the pure SCM version, but for compatibility between the two versions, we use ENTRY RIJP2 to place an image of row $j+2$ in AARWh. Remember that the same technique and buffer are avallable to any code addition requiring data lying beyond rows $j+1$ or $j-1$.

(4) In the particle movement, the area-weighting scheme reguires $u$ or $v$ velocities from two adjacent rows of cells. In the LCM version, entries RPARU and RPARV in LODP obtain the two appropriate rows from LCM, and Initialize that part of index IJ that is a function of $J$.

In the SCM version, these two ENTRY points perform only this latter task, and, again, the procedure is such that the particle mover is not concerned with whother the velocities were obtained from LCM or SCM.

(5) In the Tape Dump and Tape Restart (Regions 250 and 270 , respectively, in the HYDR $\phi$ Control Region), tests that determine whether LCM data are Involved in the dump information are included, so the user need not be concerned with this aspect.

From the above, it can be seen that the philosophy of the LCM package has been to achieve a userorlented conversion at the expense of some computer 
efficiency. The additional $\mathrm{CP}$ time required for LCM storage of cell ciata is not an unreasonable fricrease over the SCM version. For a sample calculation with $\overline{\mathrm{I}}=20$ and $\overline{\mathrm{J}}=45$, the $\mathrm{LCM}$ version grind time was about $16 \%$ greater than that of the SCM version when running at three iterations per cycle. This percentage decreases as the number of itezations increases, becoming less than $13 \%$ at 11 iterations per cycle, for example.

In the present version of KACHINA, there is provision in SCM for storing the coordinates of up to 4000 particles. If necessary, particle storage could be effectively doubled by storing coordinates at a half word each, and/or particle storage could also be moved to LCM.

With storage blcck AASC dimensioned at 26676 words, as discussed in Sec. II.C, approximately 3500 words of SCM remain available for code expansion. In the LCM conversion described here, this number increases to nearly 20000 words, and at the same time the available number of cells increases from 1250 to nearly 10000 .

AUS GOVERAMENT PAINTING OFFICE 1974-677-476/28
The SCM KACHINA user who can be sure that his memory requirements are so small that he will never require the LCM compatibility feature can definitely reduce grind time by eliminating SUBR $\emptyset \mathrm{UTINE}$ L $\emptyset \emptyset \mathrm{P}$ entirely and replacing all CALLS to its ENTRY points by copies of the instructions that the SCM version of L $\emptyset \mathrm{P}$ performs. In addition, the special considerations of the five items discussed above can be completely eliminated with very little code modification.

One final note concerning LCM usage: be sure to request $L C M$ on both the $S J \not B$ card (we add the field "LC $=400000 "$ ) and on the \$LDG $\emptyset$ card (we add the field "LC $=1000000 B^{\prime}$ ). Failure to request LCM will cause an immediate LCM Block Range Error and task abortion.

Note in proof: A "CALL D $\emptyset N E$ " should be added permanently, immediately following statement No. 619 in HYDRD. (Without this CALL, the LCM version will reference erroneous values in row $j=J P 1$ when constructing contour plots.) 